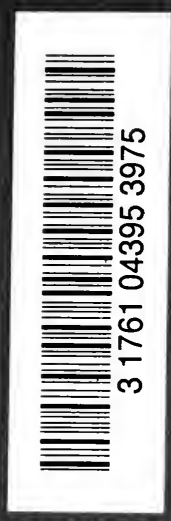


Digitized by the Internet Archive in 2007 with funding from Microsoft Corporation 



\section{ROYAL AND REPUBLICAN}

\section{FRANCE.}

A SERIES OF ESSAYS REPRINTED FROM THE 'EDINBURGH,' 'QUARTERLY', AND 'BRITISH AND FOREIGN' REVIEWS

BY

\section{HENRY REEVE,}

CORRESPONDING MEMBER OF THE FRENCH INSTITUTE.

IN TWO VOLUMES.

VOL. I.

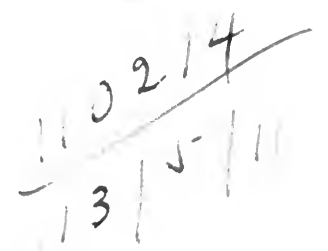

\section{LONDON :}

LONGMANS, GREEN, AND CO. 1872 . 


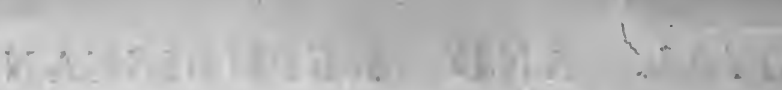
$-3+1+21=$

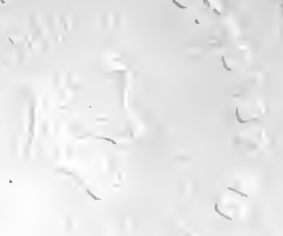

J

; 


\section{INTRODUCTION.}

The PAPERS collected in these volumes were first written and published in various Reviews at intervals extending over a period of nearly thirty years. But although the occasions and incidents by which they were originally suggested were diverse and multifarious, they have not the less a common purpose - to trace throughout the history and politics of modern France, the causes and results of the Revolution which has profoundly affected the forms of government and the state of society in that country The study of the French Revolution is, in truth, the work of a life. It comprehends all those principles which determined the rise or the fall of national greatness and prosperity-the expansion or contraction of free institutions - the social relations of classes - the contrast of law and authority with licence and mob rule; and it illustrates the application of these 
principles by events of unparalleled interest; by the virtues and the crimes of four generations, toiling and bleeding to attain an unaccomplished end; by the extremes of military glory and military humiliation; by the alternation of popular excesses and despotic power; and, finally, by an exhaustion of purpose and of hope, which, if it be prolonged, would scarcely stop short of the doom and destruction of a great nation.

The chapters which compose this volume touch successively on a few of these events. They do not form a narrative, nor do they profess to relate in detail any considerable portion of French history. But, in examining some of these transactions, and the lives of some of the eminent men who have borne a part in them, the writer has endeavoured to extract from them their common bearing on the great fact of the Revolution itself. For this purpose it is necessary to go back two centuries in order to trace in the Closet and the Court of Louis XIV., through the gorgeous pageant of national greatness, the germs of national abasement. The fatal passion for foreign influence and territorial aggrandizement, which was gratified but not satiated by the triumphs 
of $167 \mathrm{r}$ and the following years, has been chastised and avenged in $187 \mathrm{I}$ under our own eyes. Nor did the remote results of these events to France and to the monarchy escape the discerning and prophetic eye of that silent observer, Saint-Simon, who bequeathed an unrelenting sentence on his own contemporaries, to a remote posterity. These therefore form the groundwork of this volume.

The incidents of the Revolution of 1789 are best understood by an examination of the character and actions of the men and women who figured in them. Mirabeau represents the Assembly, Marie Antoinette the Court. The lives of Count Mollien and Count Beugnot are pictures of the Imperial administration in the hands of men who had passed through the storms of the first Revolution. The mission of M. de Marcellus and the reign of Louis Philippe represent the period when the haven of constitutional government appeared to have been gained; but even in those halcyon days there are abundant marks of the decomposition of society and the perils of the monarchy. The life and writings of M. de Tocqueville were devoted to the investigation of these dangers.

On more recent events it is not necessary to 
dwell in detail, for they are in the recollection of every reader at the present time. But as we look back from a more distant point of view on the whole. series of these prodigious convulsions, it becomes possible to embrace a more complete and collected view of them, both as regards the social condition of France, her relations to Europe, and her own power of local government. These, therefore, form the subjects of the essays which conclude this little work.

I cannot hope to have discovered anything in the history of the French Revolution which had escaped the sagacity of the countless writers and thinkers who have applied their genius and their experience to the discussion of these problems. But at least, at the stage we have now reached in this eventful tragedy, we have attained a point of knowledge and observation which were not possessed by our predecessors. Much that was theory, speculation, or apprehension to thern, is fact for us. We have seen before our eyes a state of society which was supposed, when they denounced it with prophetic eloquence, to be the phantasm of a gloomy imagination. At no former time, in the long annals of nearly a century of strife, has the prospect been so 
gloomy and the future so perplexing. We dwell not merely on the events of the present time, though within the past year Paris has seen massacres which equal in horror the butcheries of September, and new crimes which have consigned her palaces, her courts of justice, and her public offices to the ravages of fire. These atrocities, dreadful as they are, cannot be of long duration or frequent occurrence. But that which remains alike under the Commune and under the Empire-that which renders the establishment of any rational and stable form of free government so incalculably difficult-is the spirit of the Revolution pervading in various forms the whole structure of society. It is a disease which has eaten like a cancer into the vitals of the nation. The bitterest sarcasm ever traced by the hand of history is to be read at this moment in the words 'Liberty, Equality, and Fraternity,' inscribed with pretentious care on the tottering walls of the public edifices of Paris, which have just been stained with blood, and devastated by petroleum. But it is incomparably easier to rebuild those walls and to restore those edifices than to raise again the fabric of a State which has been ten times overthrown. 
I deem it unjust to attribute to the successive Governments of France-to Louis XVI., to Napoleon, to the Restoration, to Louis Philippe, to the Second Republic or the Second Empire-whatever may have been their faults, the failure of all these attempts to govern the country and to restore stability to the State. Rather do I conclude, from their common failure, that the task was beyond their powers, and this although they employed very different means of accomplishing it. The present National Assembly and the present temporary head of the State are animated, I doubt not-indeed I know-by the most patriotic sentiments, by a sincere preference for free institutions over absolute or military authority, and by a fervent desire to devote their intelligence, their property, even their lives, to the restoration of France. But, in the present state of social decomposition of the nation, there is not a man in that Assembly who entertains a confident hope of success, scarcely a man who does not dread worse evils in the future.

It is not so much to the forms of political government as to the revolutionised conditions of society that these evils are to be attributed. There may be 
freedom under a monarchy, there may be oppression under a republic ; and at certain epochs in the history of a nation republican government may be accepted as the safer and stronger form of power. But neither a monarchy nor a republic can stand secure when the fundamental conditions of social order are shaken-when men have ceased to trust and obey one another-when class is arrayed against class with all the bitterness of hostile castes-when faith in the common interests of the nation has disappeared, and when the rights of capital are assailed by the rights of labour.

Some writers of the extreme democratic school do not scruple to avow that their mission is the total destruction of the established order of society, as it has existed for the last three hundred years in Europe; although they acknowledge that they do not expect within the lifetime of a generation to establish anything in the place of it. When they have destroyed the belief in the existence of God and in the moral accountability of man to his Maker-when they have overthrown the authority of legal tradition, and the security of property - when they have dissolved the ties of marriage and the sanctity of domestic life- 
when they have substituted a uniform democratic equality for the hateful ascendancy of rank, wealth, and intelligence, they will doubtless have accomplished their dreadful enterprise. The deeds and declarations of the Commune of Paris are the most explicit manifestation of their principles and their designs : the conflagration of the city is its final result. But, setting aside the excesses of these maniacs, can it be denied that the whole course of the French Revolution has tended to these objects? and that it has ended for the present in a state of Nihilism, which threatens to render every form of government impossible, but the brutal restraint of the sword, wielded by some adventurer more unscrupulous than his fellows?

If this be the last expression of democratic opinions, it needs no great foresight to perceive that democracy, in the hands of such men, would bring about the annihilation of society and the destruction of the prosperity and civilisation of Europe. More formidable than the hordes of barbarians who overthrew the Roman Empire, these modern barbarians, who dwell in the heart of our streets and cities, would destroy the very roofs that cover them; in the 
name of a false liberty, they would render liberty itself impossible, and in the name of humanity they would strew the earth with ruins and blood. But a short time ago it might have been said that such fears were wild and fantastical ; but within the last few months, and in the heart of the capital and chief cities of France, we have seen their work. In presence of such dangers government becomes an armed watch for the defence of society and the repression of crime, and all its more beneficent functions are in abeyance.

It may be justly urged that in this country, and probably in most of the other States of Europe, these malignant passions and fatal delusions, if they exist at all, are far from possessing the violent energy they have acquired in France, and that the strength of resistance on the part of society is infinitely greater. We willingly cherish that belief, and reject the degrading faith that nation after nation is to fall the victim to the same destructive cause. It has been well said by a recent writer, that 'the true cause of the downfall of nations is, not luxury or the irruption of barbarian hordes, but rather the exhaustion of hope and purpose. There should be 
growth; there must be hope ; there must be considerable freedom of thought and action in any nation that claims to be considered prosperous.' . . . 'But, if we wish to avoid the perils of mob-government, which, even in a short time, can put back for generations the hand upon the dial of civilisation, there is not anything we should more attend to than counteracting the prevalence of those mischievous ideas and opinions which tend to the decomposition of a State -a thing so hard to re-compose, the result of so much patience, of so much endurance, and, upon the whole, of so much magnanimity. For no great State was ever built up without the toil, self-sacrifice, and renunciation of many noble persons in many generations.' 1

The results of the French Revolution are a palpable demonstration of these truths, and there never was a time in the history of mankind when it was more important to lay to heart its irresistible lessons. For these reasons I have ventured to collect and republish these chapters of the history of France, before they are entirely forgotten.

H. R.

1 Arthur Helps, Thoughts on Government, p. 220. 


\section{CONTENTS}

OF

\section{THE FIRST VOLUME.}

LOUIS XIL. .

SAINT-SIMON

MIRABEAU .

MARIE ANTOINETTE

BEUGNOT

MOLLIEN
PAGE

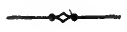

I

105

I 73

239

301

355 
1 


\section{LOUIS XIV.}

VOL. I. he 



\section{LOUIS XIV:}

We have no hesitation in assigning to these volumes a very conspicuous place amongst the recent contributions to historical literature. As a collection of state-papers they are of matchless interest: whilst the care with which the despatches have been selected, and the style of the eminent historian who has interwoven them in a regular narrative, relieve the series from that prolixity and redundancy which almost invariably repel the general reader from a collection of the 'materials for history.' The work must be regarded as the most authentic and the most animated political record of the reign of Louis XIV. : from the abundance and importance of the documents, now first made public from the archives of which M. Mignet is the official guardian, it combines the novelty of

1 This paper was first published in the British and Foreign Review, No. xxxii., for May 1844, as a review of the work entitled: Négociations relatives a la Succession d'Espagne sous Louis XIV, ou Correspondances, Mémoires et Actes diplomatiques concernant les prétentions et l'avénement de la Maison de Bourbon au trône a'Espagne. Accompagnés d'un texte historique, et précédés d'une introduction par M. Mignet. 4 vols. 4to. Paris, 1835 et 1842 . 
contemporary narrative with the gravity of critical history; and it illustrates the policy of the Cabinet with as much accuracy and vivacity as the pen of St.-Simon has imparted to the annals of the Court.

The succession of Spain, or in other words the spoliation of that crown, which tottered for forty years on the head of an impotent prince-the last and weakest of his enfeebled race-was the one great motive which directed the whole reign of Louis XIV., in his wars, in his councils, by his ambassadors, his ministers, and generals, in his alliances and in his declarations of hostility. That was the ' fixed mark' of his ambition, to which all the force and fraud, the wisdom and the falsehood of his long reign tended. That indeed was the all-important question, whose solution and whose consequences extended over nearly fourscore years of the most eventful period of the history of modern Europe, and which successively called forth the energy and the craft, the valour and the intrigues, of Mazarin and Don Louis de Haro, Lionne and de Witt, Louis XIV. and William III., Turenne and Condé, Marlborough and Prince Eugene, Torcy and Heinsius, the Regent of France and Alberoni. With the majority of Louis XIV. this great drama commenced. The various forms which his policy 
assumed were shaped by temporary circumstances to particular objects ; but the general end was invariably the same, from the moment when in the Isle of Pheasants he took the oath of renunciation, which it was even then his intention to violate, to the closing scenes of his life, when he accomplished one of the great objects of his reign, though win diminished glory and declining strength.

It was not, however, to the succession of Spain, as it was understood after the death of Charles II., that the original views of France were directed in the earlier years of the reign of Louis, and in the politic schemes of the great statesmen of the seventeenth century. The establishment of a Bourbon dynasty on the throne of Madrid was the result of events which were not foreseen when the curious diplomatic operations recorded in these volumes were begun. The advantage sought by France was of a more direct kind. The policy of Louis XIV. at the commencement of his reign was exclusively directed to the aggrandizement of his own territories ; and it was to the occupation or conquest of the Low Countries, brought into the imperial house by the marriage of Mary of Burgundy, that he chiefly aspired. Provided he could acquire Spanish Flanders, Louis was willing to leave the kingdoms 
of Spain, and by far the larger portion of that huge ungoverned empire, to the house of Austria or to any other claimant. But to him the main incentive in the best years of his power was, in reality, the acquisition of what had once been the possessions of the Dukes of Burgundy. Above all things he laboured to achieve the yet unaccomplished object of French ambition, and to leave no foreign garrisons between Paris and the Rhine. To this object of paramount national interest, the extension of his power in the south of Europe and even the humiliation of the house of Austria were subordinate; for though other countries might have added the glory of foreign dominion to his sceptre, the acquisition of Flanders could alone have completed the territory of his kingdom.

To all these designs, to all these intricate combinations of passion, artifice, and power, the final event of the War of Succession and the reign of Louis XIV. opposed a strange and contradictory result. He succeeded in placing a Bourbon on the throne of Spain, he succeeded in sweeping the Pyrenees from the confines of France, he succeeded in driving the house of Austria from its southern throne; but these successes were accompanied by defeat, humiliation, and loss on his own frontier; he was 
weakened where he had sought to extend his strength ; and the Netherlands were annexed to the Empire by the same treaties which acknowledged the Duc d'Anjou as King of Spain.

It is not, however, to the events of the War of Succession, or to the negotiations which terminated that eventful struggle in which Marlborough had fought, by the contemptible compromise to which Bolingbroke acceded, that we desire to draw the attention of our readers. The state-papers now before us are of a much earlier date; and we are about to trace in the earlier period of Louis XIVth's reign the more secret objects and contrivances of his policy, which have in many remarkable instances been as effectually concealed from the knowledge of the world by the altered course of events as by the fidelity of the agents employed by the French Court, until their own account of these extraordinary proceedings passed, in the volumes before us, from the archives of state into the open daylight of history.

We cannot, however, enter upon this vast and wonderful narrative without expressing our admiration of the consummate skill with which M. Mignet has executed his task. Hitherto this work has remained, as it were, secluded from the public in that 
magnificent collection of historical memorials which are prepared by the munificence of the French Government for distribution rather than for sale; but as it advances to its completion,-for it must obviously extend to the Peace of Utrecht,-we cannot doubt that in a more accessible form it will take its place amongst the most captivating historical productions of our age. It is no light praise, but a well-earned tribute to the editor of these volumes, that, even by the side of the original compositions of the ministers of the most polished Court in that most polished age of French letters, M. Mignet's own style and the survey of the political elements which he has evoked from the dust of nearly two centuries are not unworthy of the language or the sagacity of the age they are intended to illustrate. The huge mechanism, once worked by hidden and unknown powers, is suddenly set in motion again to satisfy the curiosity of another race. There is the activity of life in every page, and the very uncertainty which attends the march of present events lends an additional charm to this contemporary record of their progress.

Rapid and fearful had been the decline of the Spanish monarchy from the triumph of St. Quentin and the treaty of Cateau-Cambresis to the last and 
worst stages of humiliation, penury, and defeat. Less than a century divided the height of its glory from the depth of its misery and impotence; for such was the period which had elapsed between the entry of Spanish garrisons into Rouen and Paris and the Treaty of the Pyrenees, which secured the ascendancy of France, and opened, by the marriage of Louis XIV. to the Infanta, those claims which his perfidy prompted him to assert and his power enabled him eventually to maintain. The ruin of the League had for ever terminated the encroachments of Spain on France; the destruction of the Armada annihilated her designs against England and her fleet; the emancipation of the Low Countries wrung from the most Catholic and absolute Court in Europe the recognition of a Protestant republic; and the bigotry of the internal administration of Spain crushed the elements of the strength and prosperity of the country. The errors which Philip II. had learned from his intolerance were persevered in by Philip III. and the Duke of Lerma from ignorance. The proscription of the Moriscos completed the extirpation of the commercial population of the Peninsula. In the following reign the remnant of the Spanish army was destroyed; a great part of Flanders was annexed to Holland or to France; Portugal was once more 
severed from the Spanish Crown; Naples and Catalonia were in revolt ; the State was obliged to borrow a few Genoese galleys to keep up its communications with its Transatlantic dependencies; and the population of Spain was reduced to six million inhabitants, -less than half the present number of the Spanish people, less than one-third of what it had been in the best days of the Arabs at Cordova.

Meanwhile the genius and the power of France had been fostered by men and by events. Henry IV., Richelieu, and Mazarin had successively consolidated the internal tranquillity of the kingdom, organised its military and financial resources, and laid the foundations of that vast and ambitious system of foreign policy, which began with the humiliation of the house of Austria at the Peace of Westphalia, and ended by its ejection from the throne of Spain at the Peace of Utrecht. Such were the precursors of Louis, and such the posture of affairs, when the death of his great minister called the youthful monarch to the exercise of the supreme power. $\mathrm{He}$ resolved to devote six hours a day to the affairs of State; he enjoined upon his secretaries of State to sign nothing without his privity and sanction. His mother and the courtiers smiled at a resolution which they regarded as a youthful caprice rather than the 
lofty purpose of a ruling mind. He persevered, however, for fifty-four years ; and left to the world, even amidst the dissipation of a luxurious Court, a memorable example of his own maxims, that to reign is to work, and that the essence of monarchy in its absolute form consists in the untiring activity and the unflinching decision of a king.

If we hesitate before we assent to the addition which the admiration of his courtiers and the pride of his people annexed to his name, it is because, if he was great (to borrow an expression of an accomplished writer), he was only as great as it is possible to be without virtue. These records of his reign exhibit abundant and undeniable proofs of the strong and sagacious policy, the fertile ingenuity, the unbending spirit of a man born to play a foremost part in the drama of history. His policy may have been based on the traditions of his predecessors, and served by the incomparable ability of his own ministers, but the will which sustained and perfected the work was his own. It survived his most faithful servants; it persevered with as much determination, and spoke in as lofty a tone, in the days of terror and rlefeat as in the midst of his youthful triumphs; and even at the close of a life which was overclouded by danger; affliction, and bigotry, it fell but little short 
of the wide designs of his youth. But by the side of such elements of power and greatness, these papers lay bare the most hideous evidence of political profligacy that the world has ever seen in an authentic form ; an ambition which knew no bounds; corruption and dissimulation of the most unscrupulous kind; compacts of partition concluded with his hereditary foes and against kindred princes; wars wantonly carried on against confiding allies; and the establishment of a vast scheme by which every State in Europe was made, consciously or unconsciously, to bear a part in the great object of the spoliation of the dominions of Spain.

The precursors of those military campaigns, which were undertaken with such celerity and boldness that they wore the appearance of a boundless impetuosity and a blind ardour for conquest, were negotiations conducted with a prudence, a dexterity, and a patience which had secretly undermined the whole political fabric of Europe. The world was startled by such events as the irruption into Spanish Flanders, the war of Holland, the seizure of FrancheComté, and the detention of the Duke of Lorraine, because it was ignorant of the all-embracing plan in which these great events were but the passing incidents. For six years, from 1661 to 1667 , these 
diplomatic operations were silently conducted with an energy and a discretion which deserve to rank in the scale of political ability above the triumphs of successful war. Before the death of Philip IV. a negotiation had been opened with Spain to obtain the revocation of the marriage renunciation of Louis, and the admission of what were termed the rights of devolution to the Spanish Netherlands on behalf of the Queen. At the same time it was necessary to prepare the Dutch, then closely united to the policy of France, for the pretensions afterwards to be put forward by that Power, which were scarcely less formidable to the independence of the neighbouring provinces of Holland than to the security of the viceregal government at Brussels; and on this point the French Court found itself already opposed by the inflexible patriotism of John de Witt. Nor was it less important to prevent, by negotiations at Ratisbon, the Diet of the Empire from extending its protection to the circle of Burgundy; and, by securing the alliance of the ecclesiastical princes on the Rhine and of the Powers of Northern Germany, to oppose an obstacle to the possibility of the Emperor's marching to the assistance of Spain, whenever the crisis of invasion should arrive. In like manner, and by the same means, a diversion was prepared in the Penin- 
sula by inciting Portugal to attack the enfeebled Court of Spain within its own territories, whilst Louis should wrest from it its northern dependencies. Sweden and England, which were subsequently to become the direct abettors of the encroachments of France, were at present reduced to a state of neutrality by subsidies; and by a masterstroke of policy the Emperor Leopold himself was induced to join with France in a secret treaty for the complete partition of the Spanish dominions on the death of the miserable infant whose precarious life was the only barrier that intervened between Louis and the accomplishment of these vast projects. Feeble as it was, however, that barrier remained unmoved for nearly forty years. The puny child, whose hours seemed to be numbered before he mounted the throne in 1665 , outlived the century, and baffled by his lingering existence the combinations prepared even before his accession, and based on the imminent probability of his early death. After that event, but not till then, the War of Succession began; and the testament of the last king of the house of Austria favoured the ambition of France. But Louis XIV. was then no longer in the heyday of youth, surrounded by such advisers as Lionne in the cabinet and Turenne in the field : he no longer enjoyed that unquestionable 
superiority of intellect, resolution, and resources over all his contemporaries, which in his earlier years had seemed to throw the whole of Europe into the shadow of the glory of France. The influence of Madame de Maintenon and the services of Chamillart had succeeded to the counsels of such ministers as Lionne, Colbert, and Louvois ; and he had to encounter in foreign States, not the corrupt servility of the Stuarts, not the debile intrigues of the Court of Vienna, but the vigorous and wary character of William of Nassau, and the first-rate military abilities of Marlborough and Eugene. So striking is this contrast between the state of Europe at the time when these negotiations were opened, and at that late period when their consummation was at length effected, that he who compares even the most brilliant achievements of the reign of Louis with what he might have accomplished if the opportunity, the expected opportunity, had been given him thirty years before, will be struck with grateful amazement at the slight and simple fact-the mere vitality of a prince scarcely able to reign-which kept at bay the intrigues of forty years, and restrained the most aspiring Power of Europe within certain bounds until it was too late to exert the supremacy it had so long laboured to acquire. 
Little more than a year had elapsed since the marriage of Louis XIV. and the solemn renunciation of all the claims of his wife to the succession of the crown of Spain, when the Archbishop of Embrun made his entry into Madrid as the French ambassador at the Court of Philip IV. Of the 500,000 gold crowns which were to form the dowry of the Queen of France no portion had been paid; and not only from this breach of the stipulations of the marriage contract on the part of Spain, but also from the precarious position of the royal family at Madrid, a party was already formed, even in the cabinet of the minister and in the Council of Castile, who looked to the succession of the young King of France. Don Christoval, the private secretary of Don Luis de Haro himself, accosted the archbishop on his arrival with an open assurance that they expected sooner or later to belong to the King of France. The Duke of Medina de las Torres held almost the same language. The Court of Spain itself hardly seemed to regard the renunciation as valid, and Louis XIV. spoke of it in his despatches as a mere pretence. Even then the catastrophe seemed to be on the point of occurring. The archbishop prudently refrained from pressing for the open surrender of the renunciation, or the payment 
of the marriage-portion, because the course of events seemed to favour the intentions of his master. The Prince of the Asturias, then the only child of Philip IV., died on the Ist of November. For a week the Spanish crown remained without an heir, but on the 6th of the same month the Queen gave birth to another prince, who lived to bear the title of Charles II. Yet although this event changed the aspect of affairs, it did not check the urgent desire of Louis to obtain the public nullification of his renunciation, or at least to be furnished with a secret admission of the rights of his queen and his children, in case of the extinction of the male line ; and in the King's despatch of the 14th of February 1662, he directs the archbishop to give this turn to the negotiation, with the additional suggestion that Spain should at once cede to France, Luxemburg, Franche-Comté, the remainder of Hainault, Cambray, Aire and St. Omer, if not the entire investiture of the Low Countries and of Burgundy, in exchange for an alliance with France, which should enable Spain to reconquer Portugal in spite of the resistance of England. This overture led to no result, as might be expected, but we have alluded to it because it shows what the pretensions of Louis already were; and as M. Mignet has acutely remarked, the conVOL. I. 
ditions which were then respectively though vainly put forward by the Courts of St. Germain and Madrid at the outset were almost identical with the state of things which was brought about in Flanders by the result of Louis' Dutch campaigns, and in Spain by the final termination of fifty years of negotiation and of war. But it is worthy of observation, more especially with reference to the controversies which have arisen in our own time, that the original claim of Louis was expressly propounded on the ground of the ancient and fundamental law of Spain, which admitted the female succession to the throne upon the extinction of the male line. The Spanish doctors argued, on the contrary, that the successive renunciations of the daughters of Philip III. and Philip IV., who had married into the houses of Germany or of France, were to be considered as a species of Salic law : it was even proposed to introduce the Salic law; but when the Archbishop of Embrun sounded the Duke of Medina on this point, that minister replied that he knew nothing of it, and that it was a pure chimera, contrary to the fundamental laws of the state in the kingdom of Castile. The fact of the importance attached to these renunciations is conclusive as to the existence of the rights they were 
meant to bar; and the absence of the Salic law in Spain was never more clearly shown than by the claims of the Bourbon family to succeed to that throne.

It already appeared, however, that it might be long before the throne of Spain was vacant and the male line extinct; and upon the failure of this negotiation, the ambitious designs of the Court of France were directed to an object which promised a speedier fulfilment and a more direct advantage. By the custom of Brabant, the patrimony of a family descended absolutely to the children of a first: marriage, without reference to the issue of a second. Property thus devolved upon the elder female branch, to the exclusion of the younger male heir. Upon this ground and in order to colour a daring invasion of the rights of nations with a pretext of law, Louis prepared to claim the Spanish Netherlands on behalf of his queen upon the death of his fatherin-law, and to the exclusion of his wife's brother. If any such claim had actually existed, it would have been barred by the sweeping clauses of the act of renunciation; but it was demonstrated in the most peremptory manner, in the course of the succeeding negotiations, that this principle of the law of real property in Flanders was utterly 
inapplicable to the hereditary transmission of sovereignty.

The desire of Richelieu had been to erect the Catholic provinces of Flanders into an independent republic-not unlike, in purpose and in extent, the kingdom of Belgium as it has been founded within our own time. The policy of Mazarin tended to the entire annexation of those provinces to the crown of France. As early as the time of the negotiations for the Treaty of Münster, the cardinal had urged upon the French plenipotentiaries the importance of acquiring the Low Countries and Franche-Comté, even at the sacrifice of Catalonia, which was then occupied by the French troops: in language which may be said to contain the unvarying expression of a policy which France has not abandoned for two centuries, he said,-

The acquisition of the Low Countries forms an invincible bulwark to the city of Paris, which might then indeed be called the heart of France, and would be placed in the most secure part of the kingdom. Its frontier would then be extended to Holland; and on the side of Germany, where we have also much to fear, as far as the Rhine, by the retention of Lorraine and Alsace, and by the possession of Luxemburg and the country of Burgundy.

At Münster this project was destined not to be fulfilled, and at the Treaty of the Pyrenees it was not resumed; but the memorable document in which 
Cardinal Mazarin demonstrated in twelve points the importance of this acquisition was not lost upon such pupils as Lionne and Louis XIV., nor ever afterwards forgotten in the cabinet of France. But whenever it was revived, it could not but excite the liveliest apprehensions on the part of Holland and of Austria. M. de Witt, foreseeing, with a sagacity to which Louis XIV. and his ministers were wont to render the testimony of unequivocal respect, that the decline of the power of Spain could not but lead to a very formidable demonstration of the energy and resources of the youthful king of France on the frontiers of the United Provinces, had endeavoured to provide against the danger by reviving the more prudent scheme of Cardinal Richelieu. As far as his personal interests were concerned, in opposition to the Orange party in Holland, John de Witt was not insensible to the advantages of adhering to the alliance of France; but he was too enlightened a statesman not to discover that the storm which was about to sweep over Flanders would be fraught with present and future peril to Holland, and he was too upright a man to sacrifice the safety of his country in order to share in the splendid but selfish and perfidious policy of his French ally. The nego- 
tiations of the Count d'Estrades at this period are known to the world, and we shall not dwell upon them here: suffice it to say that they marked the rapid progress of the King's designs, and that their failure was the first indication of that difference which the sturdy independence of De Witt and the vindictive fury of Louis afterwards raised into open hostility. The defensive treaty between France and the United Provinces, which had been concluded at Paris in 1662, was the utmost limit to which De Witt was likely to extend his consent; and Louis was already so well aware that, in the event of his attack upon Flanders, he had little to expect from the United Provinces, and so unwilling to forfeit the servile connivance of England, that it was not without considerable hesitation that he took a part in the war which had broken out between the English and the Dutch in 1665. The Peace of Breda, which terminated that war after the two most disgraceful years recorded in the annals of the British navy, was likewise the term of the hostility which had so long prevailed between the two great trading and maritime Powers of Europe; and in spite of the French interest, which was still kept alive by party intrigues at the Hague and by the corruption of a profligate Court in London, the basis 
was then and there laid of that national alliance of England and Holland which was destined at a later period to oppose a successful resistance to the Court of St. Germain.

In the meanwhile the political weakness of Spain, the infirmities of Philip IV., and the excessive debility of his heir-apparent, increased the perils of that declining empire. At four years old the prince was unable to stand on his legs; he had cut no teeth, and he was still suckled at the breast. The war with Portugal was carried on without energy or success, till it ended in the fatal battle of VillaViciosa : even the Moorish corsairs began to renew their attacks upon the coast of Spain. At such a time, Louis was little disposed to support with patience the measures which had been openly taken by the Court of Madrid to frustrate his claims, by the marriage of the Infanta Margaret with the Emperor Leopold as well as by the declaration which reserved the contingent succession of the Spanish crown to that princess and the German branch of the house of Austria; and the resolute conduct of the Marquis de Castel-Rodrigo, the newly-appointed Governor of the Spanish Netherlands, roused the French Court to exasperation. Humiliated by the language which the Archbishop 
of Embrun was now authorized to hold to the Council of Castile, and exhausted by the calamities which had accelerated the miserable termination of Philip's life, the Court of Madrid found itself on the eve of a frightful crisis, as devoid of all resources as if it had already undergone the worst consequences of defeat. On the I 7 th of September, I665, Philip IV. expired. His will provided that, in case of the death of his son, the dominions of Spain should descend to the Infanta Margaret, and, failing her or her issue, to the Infanta Catherine, Duchess of Savoy. The second article of this testament, after. declaring that the incompatibility of the thrones of France and Spain had passed into a fundamental law, and after recapitulating the successive renunciations of Queen Isabella of Bourbon, Queen Anne of Austria, and the reigning queen of Louis XIV.. insisted in the most peremptory manner on the exclusion of the French line from the throne; and added with peculiar emphasis, by the roth article, that the States of Flanders and the Netherlands were on no account to be severed from the hereditary dominions of the Spanish crown. The archbishop suggested to his Government the propriety of protesting against these clauses in the will; and his despatches are a singular combination of the flattery 
of the courtier, the astuteness of the diplomatist, and the scholastic research of a churchman and a lawyer. But Louis had already settled the point on a former occasion by briefly observing that it was not by a little more or less writing that the question would be determined.

The sacerdotal character and the theological casuistry of the Archbishop of Embrun were not misplaced at the Court of Madrid, where Father Nithard, the confessor of the queen-regent, already exercised an undisputed power. But the diplomatic prelate was not one of those agents on whom the Court of St. Germain. principally relied; he was even kept in ignorance of the storm which was about to burst upon the territories of Spain; and he was himself scarcely less surprised than the Council of Castile when he was suddenly instructed to notify to that body the instant irruption of the French forces into the Low Countries. In reality, the attention of the French cabinet was directed to every quarter of Europe with more earnestness than to Madrid. A vital disease was already eating away the life of the Spanish branch of the house of Austria: the chief care of its enemies was to cut off every channel of assistance and every means of cure. 
The neutrality of England and the hostility of Portugal were already secured; but the most important point was to establish the paramount ascendancy of Louis in Germany, and to paralyse that assistance which the ties of blood and the suggestions of policy would claim for Spain from the Court of Vienna. The jealousy of the house of Austria entertained by the petty sovereigns of Rhenish Germany had already placed them in strict dependence on the Court of France. The League of the Rhine, negotiated in $165^{8}$ by M. de Lionne under the orders of Mazarin, had already united the Court of France in a close offensive and defensive alliance with the Electors of Mayence, Cologne, Treves, Bavaria, the King of Sweden, and the Dukes of Brunswick, Lüneburg, and Hesse-Cassel. Their united forces were commanded by the Prince de Salm, a French officer. In I664 France had concluded treaties with the Elector of Saxony, who had sold his vote in the Diet to Louis XIV. for an annual stipend of 20,000 crowns. The King of Sweden received 100,000 crowns a year; the Elector of Mayence 10,000, and afterwards 20,000 crowns, whilst the alliance lasted. The King of France was the real head of the German empire; and the policy of the Treaty of Westphalia, which had stripped the 
Emperor of his legitimate power, was fulfilled by the servility and corruption of the princes of the empire, who transferred that power to his great rival. In 1667 Louis had need of all his influence and his alliances to prevent the possibility of Leopold's marching an imperial army to the relief of Spanish Flanders. Fresh treaties were concluded for this purpose with the Electors of Mayence and Cologne, the Duke of Neubourg and the Bishop of Münster. By these secret conventions the German princes bound themselves not to suffer the passage of a German army, and Louis engaged to pay them each subsidies of 36,000 rix-dollars per annum, which were to be raised to 130,000 dollars in the event of a rupture with the house of Austria. The banks of the Rhine were literally sold to the Court of St. Germain, and the same influence penetrated by similar means through the whole of northern Germany. Even in Hungary means were taken to check, by a formidable diversion, any design which the Austrian Government might show of opposing the growing power of France upon the Rhine. The communication with Flanders was intercepted by the confederation of the Rhenish princes, and the internal resources of the empire were skilfully undermined. Nothing was left to chance-every- 
thing was foreseen. Charles II. of England deposited in the hands of his mother, Queen Henrietta Maria, who lived at Chaillot, a solemn engagement to enter into no combination hostile to the interests of Louis XIV. for the space of one year; and from one end of Europe to the other not an ally was left to Spain.

The internal resources of France were not less formidable and complete than her diplomatic preparations. Her finances and her fleet, both of which Mazarin had grievously neglected, were restored by the skill and care of Colbert and Lionne. The followers and pupils of the cardinal were destined to raise to an unprecedented height that system of foreign influence, military power, and national prosperity which the conqueror of the Fronde and the founder of absolute monarchy in France had only looked to as a promised land. The revenue of the kingdom was doubled. The fleet which had been created by Richelieu, though subsequently neglected by his immediate successor, reckoned in I 666 no less than I Io vessels, carrying 37 I 3 guns and 2I,9I5 men. The army, after the Peace of the Pyrenees, retained an effective force of I 25,000 men, and its operations only awaited the pleasure of Louis XIV. and the guidance of 
Turenne. Early in March the preparations for the campaign were completed, and in May the war began. Thus, whilst the young King of France had means at his disposal which would have rendered him formidable to a coalition of all the Powers of Europe, that coalition was in fact directed, by the corruption of some Courts and the connivance of others, against the dependencies of the friendless and feeble throne of the infant King of Spain. Such, on the other hand, was the absolute destitution of the Court of Madrid, that a paltry subscription was got up amongst the nobles, to which the dukes and cardinals contributed a donation of 2,000 pistoles each and the Council of Castile half a year's salary, to save the monarchy from dissolution.

It deserves, however, to be remarked that, in spite of its own resources and the penury of its adversary, the French cabinet thought fit to commence its operations by the publication of a book. The first overt act which announced the hostile designs of Louis XIV. to the Court of Spain and to the world, was the production of a volume of 3 I 8 octavo pages, entitled 'Traité des droits de la Reine Très-chrétienne sur divers États de la Monarchie d'Espagne.' In this work the nullity of the King's renunciation and the doctrine of devolution as applied 
to the Spanish provinces of Flanders, were asserted with the address of a skilful advocate. Our limits forbid us to enter upon the arid and unconvincing arguments put forth in support of these most untenable propositions of royal logic and unscrupulous ambition. The point of law had been already decided by the learning and equity of De Witt, who had been corsulted in the preceding year; and the claim itself, even if it had been founded on the basis of absolute justice or the immemorial customs of the realm, instead of being a fraud, a fiction, and an innovation, was one which the Court of Spain was bound to resist to the last extremity, for it involved the dismemberment of the empire.

It was sufficiently bold in the French (says Lord Bolingbroke) to argue from customs that regulated the course of private successions in certain provinces to a right of succeeding to the sovereignty of those provinces; and to assert the divisibility of the Spanish monarchy with the same breath with which they asserted the indivisibility of their own; although the proofs in one case were just as good as the proofs in the other, and the fundamental law of indivisibility was at least as good a law in Spain as either this or the Salique law in France. But however proper it might be for the French and Austrian pens to enter into long discussions and to appeal on this great occasion to the rest of Europe, the rest of Europe had a short objection to make to the plea of France which no sophisms, no quirks of law could evade. Spain accepted the renunciations as a real security; France gave them as such to Spain, and in effect to the rest of Europe. If they had 
not been thus given and thus taken, the Spaniards would not have married their Infanta to the King of France, whatever distress they might have endured by the prolongation of the war. These renunciations were renunciations of all rights whatsoever to the whole of the Spanish monarchy, and to every part of it. The provinces claimed by France were parts of it. To claim them therefore was to claim the whole; for if the renunciations were no bar to the rights accruing to Mary Theresa on the death of her father Philip IV., neither could they be any to the rights that would accrue to her and to her children on the death of her brother, Charles II. ${ }^{1}$

The only public servant of the crown of Spain who appears from the first to have foreseen the impending storm, and to have prepared to meet it, was the Marquis de Castel-Rodrigo, the Governor of the Low Countries ; yet, to the very last moment, his expostulations and entreaties were looked upon at Madrid as mere attempts to extract money from the impoverished treasury of the kingdom. On the very eve of the rupture, he addressed to Louis XIV. a remonstrance and a proposal for negotiation, in language of singular dignity and moderation. The

${ }^{1}$ Lord Bolingbroke's Letters on History, Letter 7-the most masterly sketch in our language, or perhaps in any other, of the policy of the period before us. Bolingbroke was the only political writer of the earlier part of the last century who appears to have had full cognizance of the Chevalier de Gremonville's Treaty of I668, and of the exact nature of Charles II.'s (of England) engagements with Louis XIV. He derived that knowledge, he says, 'from private relations I have read formerly, but am not at liberty to quote' - that is, from the state-papers to which he had had official access. 
King's answer, transmitted by M. de Lionne to the Spanish ambassador in Paris, was as follows :-

Monsieur,-J'avais envoyé au roi, à Champlatreux, la lettre que M. le Marquis de Castel-Rodrigo lui a écrite, et sa majesté, en me la renvoyant, m'a chargé de faire savoir à V. E. qu'elle a estimé qu'il serait fort indigne d'elle de répondre à un libelle que le dit marquis, se méconnaissant beaucoup, a eu l'audace de lui adresser en forme de lettre.

C'est toute la réponse que j'ai eu l'honneur de recevoir de sa majesté.

Lionne, however, answered the arguments of the Spanish memorial in his own person.

The chief hope of the Spanish Government lay in the assistance which they hastened to claim from the Court of Vienna. But the entreaties of the Spanish ambassador were vain; the Court of France was represented by a man whose ingenuity and presence of mind gave him an incontestable superiority over the irresolution of Leopold and the intrigues of his ministers. The Chevalier de Gremonville, a gentleman hitherto unknown either in political or literary history, was at that time the representative of Louis XIV. at the Imperial Court. The volumes before us have for the first time revealed to the world a politician of such consummate dexterity that his influence over the conflicting elements of a jealous Court may be said to have determined the success of 
the war, and, if circumstances had favoured his combinations, they would have changed the fate of Europe; whilst as a writer M. de Gremonville is scarcely less graphic than St.-Simon himself. The peảantic Court of Vienna, where two succeeding centuries seemed scarcely to do more than change the name of the reigning sovereign, is drawn to the life; and the gay and active Frenchman figures in that august circle with an elf-like celerity of mischief which confounds the stately grande ur of the Lobkowiczs, Schwarzenbergs, Auersbergs, and Thuns.

That part of Flanders which belonged to the circle of Burgundy was not the less an object of Louis' ambition, although it had a direct claim to the protection of the Empire. But Leopold, surprised by the announcement that his youthful contemporary was already riding at the head of his army into the marches of Brabant, was in no condition to proceed to the relief of the Court at Brussels. Austria protested that she had always believed the Treaty of Westphalia to be indestructible, and the Peace of the Pyrenees eternal; and Prince Lobkowicz was already more disposed to lend himself to the spoliation of the Spanish crown than to advance to its relief. The Emperor would do nothing with-

VOL. I. 
out the support of the Diet; and at Ratisbon many of the princes were already in the pay of Louis, whilst the rest were little inclined to brave his anger. To enable the princes of the Empire to refuse with a better grace the passage of the Imperial troops, if it were demanded, Louis condescended to supplicate for permission to despatch I 2,000 men into Poland to fight the Turks,-a demand which he knew would be refused, and would thus serve to render a similar demand on the part of the Imperial Cabinet less admissible.

The campaign had been begun without a declaration of war. The archbishop had been left in real and total ignorance of the military preparations of his master; and he acknowledged to Lionne, with becoming submissiveness, that no minister is so well able to deceive a foreign court as he who is himself deceived. The French ministers all over Europe protested that the mere fact of their master proceeding to occupy cities, fortresses, and provinces which he claimed in right of his Queen, was not to be regarded as war; and they persisted in this assertion with unparalleled coolness. At length, however, war was declared by Spain, and the archbishop ordered to leave Madrid, which he did in very handsome style. 
Je pars d'ici avec un très-grand équipage de quarante chevaux ou mules, carrosse, litière, calèche, vingt mulets de charge (sans compter ceux de M. Recamera), couverts de fort belles couvertures, pages, laquais, gentilshommes et quelques officiers réformés qui se joignent à mon escorte. J'ai cru que je devais sortir de cette cour avec quelque sorte d'éclat en cette conjoncture.

On the 6th of August the ambassador set out, and he wrote to $\mathrm{M}$. de Lionne from Vittoria on the I8th, to give him an account of his pompous exit from Madrid and his armed progress across Spain :-

Je suis parti de Madrid, le 6 de ce mois, sur les six heures du soir, où beaucoup de gens étaient aux fenêtres et dans. les rues pour voir passer mon équipage, dont je ne vous répéterai point ici la magnificence, qui était fort extraordinaire pour un ambassadeur de retour. Mon suisse était à cheval devant mes mulets, couverts de fort belles couvertures en broderie avec mes armes, mes écuyers et mes pages avec mes chevaux de main, mes laquais à l'entour de mon carrosse et de ma calèche, et vingt cavaliers derrière pour mon escorte. Toutes les personnes de condition me firent de grandes salutations des carrosses ou des fenêtres, et les gens du peuple criaient : Dios le neve bien! (Dieu le conduise!). L'on peut juger de là quelle est l'impression de la grandeur du nom du roi dans l'esprit des Espagnols, qui ont témoigné, même dans cette dernière heure, au milieu de la guerre, un respect pour moi qui n'est pas imaginable, et qui a toujours affligé au dernier point les ministres d'Espagne par un pronostic d'un changement d'état.

At Vienna the rapid progress of the French armies was viewed with increasing alarm. Armen- 
tières, Charleroi, Bergues, Furnes, Tournai, Douai, and Oudenarde had already surrendered to Turenne. That general had retired from before Dendermonde, which had been relieved; but he laid siege to Lille. The lines were opened on the I8th of August, and the place capitulated on the 27 th. On the 8th of September this event was known at Vienna. M. de Gremonville's account of the arrival of the news is highly characteristic.

Le 8 du courant il arriva de Flandre un courrier à l'ambassadeur d'Espagne pour lui donner part de la prise de Lille ; et quand je n'aurais pas su d'ailleurs les mauvaises nouvelles qu'il apportait pour eux, je m'en serais bien aperçu par le morne silence qu'on garda ce soir-là au souper de l'empereur et des deux impératrices, où je ne me serais pas trouvé par modestie, si M. le grand chambellan ne m'y eût donné rendez-vous pour lui parler ; mais je me gardais bien de témoigner rien savoir, pour leur montrer que j'étais beaucoup plus circonspect qu'ils n'avaient été en me venant dire en foule, comme ils firent il y a quinze jours, cette imaginaire perte de six mille hommes à Dendermonde. Mais à la fin ils ne purent s'empêcher de s'expliquer de la prise de Lille : je montrai ne les pas croire, et que c'était peut-être un autre artifice clu marquis de Castel-Rodrigo, pour tâcher par toutes sortes de moyens d'obtenir des secours, puisque je savais qu'il écrivait que toute la Flandre était perdue si l'empereur ne se déterminait pas promptement à une déclaration ouverte, pour laquelle obtenir les Espagnols affectent de publier le siége de Gand, sa perte inévitable, et de plus que M. de Marsin est assiégé avec trois mille chevaux par une partie de l'armée de votre majesté.

L'ambassadeur de l'Espagne, contre sa coutume, ou pour montrer sa plus grande consternation, n'apporta point lui-même cette 
nouvelle à l'empereur, mais la fit seulement savoir au grand chambellan, et par un billet à la camarera mayor, laquelle, se trouvant auprès de l'impératrice, fut assez malhabile d'en faire la lecture en sa présence, dont s'étant évanouie, cette princesse en fut si effrayée qu'elle crut qu'il était arrivé quelque grand accident à la reine sa mère. Les Allemands ne trouvent pas bon qu'on lui communique ces sortes de matières, qui pourraient porter un grand préjudice à sa grossesse. Enfin, sire, jamais nouvelle n'a causé une telle surprise, d'autant plus qu'on s'était imaginé fort légèrement que votre majesté ne réussirait point à cette entreprise, et qu'elle y consommerait son armée en trois mois de siège, ce que la flatterie de certains Français renégats qui sont ici leur donnait plus à croire encore, et dont on commence à se prendre garde. Je me sers exprès, à fin de me mieux moquer d'eux, des mêmes avantages qui rendaient, à leur dire, cette place imprénable, et prétendant par là leur faire voir en temps et lieu combien de gloire votre majesté s'est acquise par une conquête si considérable, que les Espagnols même par force font valoir pour tâcher d'obtenir de l'empereur une déclaration ouverte, comme l'unique soutien à l'imminente chute de la Flandre, alléguant qu'après ladite conquête rien ne peut s'opposer à la valeur des armes de votre majesté.

Yet, notwithstanding the effects which such events were calculated to produce, the Chevalier de Gremonville's influence at Court was still sufficient to prevent the Emperor even from recruiting his army. The Spanish ambassador declared that, at such a crisis, it was not to have been expected that an emperor of the house of Austria would take a Frenchman for his prime minister ; and Louis XIV. himself praised the 'unequalled effrontery' of his 
own envoy, who had succeeded in paralysing all the movements of the Imperial Court until his master had finished his summer campaign. Louis returned to St. Germain early in September, and Turenne went into winter-quarters before any prince in Europe had taken up arms to check his progress. But already further designs were in preparation.

En tout cas (says the King in a despatch to M. de Gremonville of the 22nd September) je veux bien vous dire que si je ne puis avoir cet hiver un accommodement à des conditions équitables et modérées, je m'en vais me mettre en état que, quelque puissance étrangère qui se mêle dans cette affaire en faveur des Espagnols, non-seulement avec l'aide de Dieu je conserverai les avantages que j'ai acquis par les armes en cette campagne, mais que fort vraisemblablement rien ne m'empêchera de pousser mes progrès plus avant; et mon intention est aussi d'avoir un bon corps d'armée en Alsace, au commandement duquel j'ai destiné mon cousin le prince de Condé, que j'ai envoyé quérir à Chantilly, pour le faire partir, avant qu'il soit huit jours, et se rendre à son gouvernement de Bourgogne, où il commencera à prendre soin des troupes qui devront composer ladite armée.

\section{A few days afterwards Lionne writes as follows :}

Sa majesté a exécuté ce que je vous mandais par votre gentilhomme à l'égard de Monseigneur le Prince. Il est presque inconcevable dans quels transports de joie fut ledit seigneur prince, quand elle lui déclara qu'elle le faisait général d'une armée de 25,000 hommes sur le Rhin.

That army was destined to the brilliant winter campaign in Franche-Comté. 
The success of M. de Gremonville's endeavours to prevent the Court of Vienna from engaging in the war and sending troops to the relief of Flanders, seems the more extraordinary when it is remembered that the Emperor Leopold was at that moment the heir presumptive to the Spanish monarchy, and that every post might bring him the intelligence of the death of Charles II. In defending Flanders, the Court of Austria would have done no more than defend the integrity of those dominions which, by the will of Philip IV., it might already regard as its own. The views, however, with which the Imperial Cabinet contemplated the opening of that vast inheritance were of a far more pusillanimous nature ; and already M. de Lionne had detected, with the sagacity which guided the movements of the Court of St. Germain, that it would not be impracticable to induce the Emperor to consent to an eventual partition of the dominions of the Spanish crown. The history of this negotiation is one of the most curious parts of these collections ; for although the fact that such a treaty had been concluded was vaguely divulged in the beginning of the last century, and is alluded to by Voltaire, yet the tenour of its articles and the incidents of the negotiation were unknown till the appearance of the work before us, in 


\section{which the original documents are laid before the} world. ${ }^{1}$

\section{To France such a treaty was the confirmation of}

1 Voltaire probably asserted the existence of this treaty from the notes of Pelisson and Grimoard. The passage in the Siècle de Louis $X I V$. deserves to be cited :-

'Tous les frères de Charles II, roi d'Espagne, étaient morts : Charles était d'une complexion faible et malsaine. Louis XIV et Léopold firent dans son enfance à peu près le même traité de partage qu'ils entamèrent depuis sa mort. Par ce traité, qui est actuellement dans le dépôt du Louvre, Léopold devait laisser Louis XIV se mettre déjà en possession de la Flandre, à condition qu'à la mort de Charles, l'Espagne passerait sous la domination de l'empereur. Il n'est pas dit s'il en coûta de l'argent pour cette étrange négociation : d'ordinaire ce principal article de tant de traités demeure secret. Léopold n'eut pas sitôt signé l'acte qu'il s'en repentit : il exigea au moins qu'aucune cour n'en eût connaissance, qu'on n'en fît point une dou ble copie selon l'usage, et que le seul instrument qui devait subsister fût enfermé dans une cassette de métal, dont l'empereur aurait une clef et le roi de France l'autre. Cette cassette dût être déposée entre les mains du grand-duc de Florence. L'empereur la remit pour cet effet entre les mains de l'ambassadeur de France à Vienne, et le roi ênvoya seize de ses gardes du corps aux portes de Vienne pour accompagner le courrier, de peur que l'empereur ne changeât d'avis, et ne fît enlever la cassette sur la route. Elle fut portée à Versailles, et non à Florence ; ce qui laisse soupçonner que Léopold avait reçu de l'argent, puisqu'il n'osa se plaindre. Voilà comment l'empereur laissa dépouiller le roi d'Espagne.'

The sarcasms and the facts of Voltaire in this passage are alike unjust and inaccurate. Leopold received no money in the course of the negotiation. Two copies of the instrument were signed, and one of them is doubtless at Vienna at this moment, as well as at Paris. Nothing could be more dissimilar than the treaty of 1668 and the negotiation for partition after the death of the King of Spain. Lastly, there is no evidence that Leopold repented of this treaty, for it furnished him with a powerful motive for keeping Louis at peace with the empire, and this very argument was used with great force by Gremonville some time afterwards to prevent the Imperialists from assisting the Dutch on the invasion of Holland. The most mischievous part of the treaty was the fact of its having been signed at all. 
the highest hopes of the king. On her side she negotiated her vague pretensions, supported indeed by a force calculated to make even them respectable, against the positive rights of the house of Austria ; and she obtained the full recognition of the conquests already made in Flanders from the only power able to contest them, whilst at no distant period she might look forward to the peaceable attainment of what was then the principal object of her ambition. Austria already abandoned the strong ground of the renunciation, which was shortly afterwards so imprudently and feebly given up by the parties to the Triple Alliance; and thus at the very outset the whole question of international law was surrendered to the pleasure of Louis.

The first proposal of this partition had been made indirectly to the Court of Vienna by Prince William of Fürstemberg, an envoy of the Elector of Mayence, acting on behalf of Louis XIV.; but this negotiation was speedily brought to a conclusion, and its failure, which was no secret, served as a foil effectually to conceal the scheme when it was shortly afterwards resumed with the deepest mystery between Princes Lobkowicz and Auersberg and M. de Gremonville. The Imperial Cabinet appears to have embarked in this extraordinary arrangement with singular zeal. 
Lobkowicz was a firm adherent of the French party ; his colleague Prince Auersberg had been bought over by a promise that the King of France would solicit a cardinal's hat for him from the Pope. Leopold himself had made a vow to St. Anthony of Padua for the success of the negotiation, though, as one of his ministers confidentially observed to the chevalier : 'Our Emperor is not like your King, who sees and does everything for himself; for he is a statue which may be carried wherever you please, and set up at pleasure.' It was one of the finest parts of the character of Louis, that, whenever he gave his confidence to his servants, he gave it all : he was ably served, because he gave to able men the full and unchecked liberty of serving him. No sooner had the assent of the Austrian ministers been given to the scheme, on the condition of complete and lasting secrecy, than M. de Gremonville found himself by return of courier 'devenu un grand plénipotentiaire, sans adjoint et avec entière faculté de conclure.' His powers were contained in an autograph letter of the King to the Emperor, in order to avoid the necessity of their passing the great seal ; but these powers were accompanied by instructions which bear the stamp of a master's hand.

The contracting parties were both equally eager 
to accomplish their great object of a partition, but they were not less anxious to secure the interests of their respective masters. For several days the bargain was carried on by the respective ministers, who met either in disguise or at strange and remote places to play at a game in which kingdoms, duchies, and the western hemisphere were the stakes. After having given an account of these transactions to the King, with exquisite fidelity and vivacity, M. de Gremonville says to M. de Lionne :-

C'est une véritable représentation de comédie italienne que la négociation où je suis. L'empereur y fait le second Zanni, embrouillant l'esprit de ses ministres pour faire réussir l'intrigue. Le prince Lobkowitz et le prince d'Aversperg se veulent gagner le dessus et aspirent à l'honneur de la négociation, en se trompant l'un l'autre. Le président des finances agit en Pantalon, qui fait bien du bruit pour faire commencer les levées, mais qui sous main met tout en usage pour ne point débourser d'argent. L'impératrice douairière fait la Colombine, aidant admirablement à l'intrigue, sans en bien savoir le but. Et moi je suis le Trappolin normand, qui fait le tout pour bien servir son maître. Mais vous me permettrez aussi de vous dire que vous faites le Docteur, qui donnera tout le bon succès à la chose par son admirable direction.

The difficulties, however, were gradually removed, not so much by concessions to the Empire as by suitable persuasives to the imperial minister. The chief obstacle was the strong desire of Prince Auersberg to retain, if possible, Milan, Naples, and. 
Sicily; insomuch that he appeared disposed to cede the whole of the Spanish Indies for what M. de Gremonville calls "ces trois pièces." At length, after an incredible struggle, Naples and Sicily were abandoned to France, and at two in the morning of the 20th January 1668 this memorable treaty was signed; and those who signed it believed that they had accomplished the greatest diplomatic achievement which had been known for centuries; as indeed they had, if the course of events had ever realized their previsions. It had originally been proposed to place the original documents in the custody of the Grand-Duke of Tuscany, without acquainting him with their purport; but the fear that his curiosity would defy all the precautions of seals and locks prevailed; and the French copy of the treaty was deposited in a tin box and escorted to Paris by sixteen of Louis' gardes du corps, who had been dispatched for the purpose to the gates of Vienna.

The following columns will present in the briefest

Such (suys M. Mignet) was the end of one of the greatest aftirirs crer undertaken in politics, since it was destined to distribute the vastest territorial inheritance in the world; one of the boldest, since it affected to distribute this inheritance thirty-two years before it was opened; one of the best conducted negotiations, since it succeeded; and one of the most mysterious, since it has remained secret till our own time. 
form the distribution of the dominions of the Spanish crown, as it was then agreed to by the plenipotentiaries of France and of the Empire :-

Share of the Emperor.

The Kingdoms of Spain, except the kingdom of Navarre and the fortress of Roses.

The Western InDies, including all the possessions of Spain in America.

The Duchy of Milan, with the investiture of the Duchy of Sienna.

The Spanish Ports in Italy on the Tuscan sea as far as the frontiers of Naples.

SARDinia.

The Canary Islands.

The Balearic IsLes.

If we take an impartial view of this arrangement, setting aside the considerations arising out of Louis' renunciation on his marriage, which he never intended to keep, and the rights of the people, which at that day were not much considered, we may admit that it was a prudent and not an unfair adjustment of a difficulty which threatened at no distant period to plunge the whole Spanish monarchy and the rest of 
Europe in the horrors of war. Louis and Leopold were first-cousins,-both of them sons of daughters of Philip III.: their wives, the Empress of Germany and the Queen of France, were the daughters of Philip IV., and might be considered as co-heiresses of the last Austrian princes in Spain, and co-heiresses of realms too wide for the rule of a single sceptre. Nor can we discover anything in this compact more at variance with political morality or the rights of nations than in the treaty concluded thirty years afterwards, to which William III. was a party, and against which Leopold so loudly protested in 1695 . The miserable error of the Court of Austria in 1668 was that it abandoned the impregnable ground of the renunciation of the Queen of France, and, by admitting the right of Louis to share in the partition of the Spanish empire, did in fact admit his reversionary claim to the whole dominions of that monarchy. It inspires us with a lofty idea of the terror which the arms and the character of Louis had already inspired in Europe, that the head of the house of Austria should at once consent to abandon so large a portion of those dominions to which, under the will of his father-in-law, he had an undivided claim : but, on the other hand, Louis consented to leave the fundamental possessions of the Spanish 
monarchy in the hands of the house of Austria ; in Flanders he claimed no more than he was already able to conquer; and, above all, he raised no pretensions, he intimated no hopes at that time of placing a Bourbon on the throne of Spain. The policy which had been faintly intimated in the first despatches to the Archbishop of Embrun seemed to be abandoned; and so little jealousy had been excited at Vienna by the supposed desire of the Court of France to level the national barrier of the Pyrenees, that in the course of this negotiation the Imperial ministers more than once pressed M. de Gremonville to ask for whatever he pleased in the territories of the Peninsula or the Transatlantic dependencies of Spain, alleging with an amusing ingenuousness that his master was, if anything, less hated by the Spaniards than theirs, and that he would consequently have less difficulty in governing what he acquired. The real obstacles to the execution of such a treaty would have been the haughty resolution of the proud people of Spain-as yet not altogether degenerate or forgetful of their sireswho regarded the dismemberment of the empire of Charles V. as the most heinous of indignities; and to this may be added the combination of all the minor Powers of Europe which the avowal of such a 
compact would instantly have awakened. These contingencies were to a certain extent provided against by a clause in the Treaty, providing that an offensive and defensive alliance between the Emperor and the King of France should be made to lend the necessary support to so vast a scheme.

But why dwell on a passage in history, however attractive by its mystery and its magnitude, which resembles the dream of some fantastic potentate, rather than the precise and practical conclusions of Louis and Lionne? Within a few months from the conclusion of this great negotiation, its momentary possibility was gone for ever. Human subtlety is overpowered by the drifting force of politics and empires; and the parchment which at one time would have divided the civilized globe, remains unknown and unrecorded, till it serves only to point a moral and disclose the secrets of hearts which have long ceased to beat. The authors of this treaty have had to wait nearly two centuries for their fame. In the midst of success, M. de Lionne seems to have had a presentiment of this kind : he writes to the chevalier on the receipt of the treaty as follows :-

Vous avez fait des merveilles, et je ne saurais vous exprimer la satisfaction que j'ai de vous voir si glorieux, et que vous ayez si 
heureusement manié et ménagé au profit de notre maître et à l'avantage de la chrétienté la belle matière qu'on vous avait mise en main. Vous aurez pourtant une petite mortification de ce qu'il faudra que le mérite que vous avez acquis demeure longtemps et peut-être toujours caché aux yeux de tout le monde. Mais il faut vous en consoler sur ce que le maitre le sait et le veut reconnaitre; cela doit vous suffire pour vivre désormais fort content.

Sa majesté ne vous donnera pas à la vérité les hautes récompenses où ces messieurs ont voulu élever vos pensées, et j'avoue ingénument que je voudrais bien qu'elle le fít ; car, en ce cas-là, je pourrais espérer qu'elle ne me refuserait pas la charge de connétable, puisque l'origine de tout vint premièrement de la pensée qui me tomba dans l'esprit de vous écrire le premier billet, et ensuite des instructions de sa majesté que j'ai eu le bonheur de dresser et de vous envoyer ; mais pour moi, je suis déjà pleinement récompensé de tout le service que j'ai pu rendre en cette occasion et de tous ceux que je pourrai jamais rendre; il faut seulement songer à vous, et là-dessus je vous dirai pour votre satisfaction que sa majesté m'a déjà fait l'honneur de s'expliquer à moi qu'elle vous donnerait un gouvernement et une abbaye, et je tiendrai maintenant la main à la faire souvenir de sa promesse.

Hitherto we have had little to contemplate in the brilliant and rapid triumphs of the Court of France but the striking contrast between the ability and ambition of its policy on the one hand, and the declining powers of its antagonists on the other; but already the movements of Louis were watched with a penetrating eye by a man whom the skill of French diplomacy could not deceive nor the gold of

VOL. I. 
France corrupt. The only statesman in Europe whom Louis XIV. feared was John de Witt: the only people which, in spite of all the disadvantages of a divided popular government, he could not gain or intimidate were the Dutch. The pretensions of Louis to the provinces of Spanish Flanders had from the first been coldly received by De Witt. Acknowledging the advantages which Holland had derived from an alliance with France, which was coeval with her political independence, conscious that his personal influence was in no slight degree dependent on the maintenance of what was termed the French, in opposition to the Orange party, De Witt endeavoured at first to moderate the pretensions of Louis,-failing in that, to restrain and to counteract them.

Upon the breaking out of the war of devolution, the Spanish governor of the Low Countries had at once appealed to the Dutch for assistance-a great and certainly an unwilling testimony to the power of the Republic, which could bring a Spanish envoy to the Hague to sue for succour against the King of France! At one moment De Witt hesitated. The Marquis de Castel-Rodrigo had offered Bruges and Ostend to the Dutch to purchase their assistance. That offer might have turned the scale, but it was 
soon retracted. The Grand-Pensioner contented himself with adhering to a system of neutrality, tending to mediation between the two crowns. $\mathrm{He}$ was already drawn by gradual steps to the rupture of those treaties which bound the Dutch to the political system of France, and the crisis was approaching which threw their weight into the counsels of her opponents; but it was a fatal error that he did not act upon the emergency with sufficient rapidity and determination. To trace with minuteness and accuracy the history of this important change in the balance of power, the reader must turn from the documents before us to the negotiations of Sir William Temple and the memoirs of De Witt : suffice it for our present purpose to point out the fact. The groundwork of the Triple League was already laid in the minds of those great statesmen; and, on the other hand, the repulse which Louis sustained at the Hague in the first burst of his youthful triumphs, stung his pride, and kindled the fire of that implacable revenge which was to prompt at no distant period the invasion of Holland.

In proportion as Louis ceased to rely on the devotion of the Dutch to his interests, it became expedient for him to conciliate the Court of England, as the other great maritime power, and as that to which 
M. de Witt looked for support in his pacific designs.

The Marquis de Ruvigny, a Protestant nobleman who had resided in England, and who was connected with Clarendon by the ties of friendship and with the house of Russell by marriage, was appointed to proceed as ambassador to London. The family ties of Charles and Louis, and the position of the needy and insincere King of England, had already predisposed the Court to throw itself into the arms of France. Ruvigny was instructed to strengthen these inclinations by the proposal of a treaty of alliance directed against the house of Austria both in Germany, Italy, and Spain, by which the American dependencies of those powers should be abandoned to England, their European dominions allotted to France. In addition to this, M. de Lionne recommended Louis to offer Ostend and Nieuport to the English, if they would join him in the war in Flanders; and the old and still repeated lure of a commercial treaty, which had recently been negotiated by Denzil, Lord Hollis, but not signed, was again held out.

On his arrival in London, the French ambassador found the King courteous to himself and inclined to negotiate; but Clarendon was just disgraced, Baron 
Isola, the Spanish envoy, had reached London before him, and the country was already roused to a furious jealousy of the power of France. A few influential members of Parliament ventured to call on the ambassador; but they came at night with link-boys and in disguise. The Duke of Buckingham hesitated to avow his preference for the French alliance. Lord Arlington was a warm partisan of the interests of Spain and Holland. In a word, Charles himself was the only man at Court to whom Ruvigny could open his commission. The King admitted the existence of these obstacles, but he said Lord Arlington was not so black as he was painted. At length, after several private audiences, Charles allowed the ambassador to perceive that the negotiation could only be opened on three conditions-a grant of money, a share in the conquests in Flanders, and a community of commercial interests. Louis eagerly embraced these suggestions, and on the 5 th of November ( 1667 ) full powers were sent to the ambassador to treat for an offensive or defensive alliance. But in the meantime Parliament had met, and the impeachment of Clarendon absorbed the attention of the Court as well as of the country. Charles, with his wonted fickleness, drew back, - then offered to renew his previous engagement, to enter into no league hostile to 
France for one year,-and finally, under Lord Arlington's influence, violated even that promise by authorising Sir William Temple to treat with the Dutch, whilst the Duke of Buckingham and Arlington himself were making to $M$. de Ruvigny the following proposal :-

Projet d'un Traité secret entre les deux Rois contre les Etats des Provinces-Unies, qui s'expliquera de la manière suivante:-

Si la France et les États généraux en viennent à une rupture, l'Angleterre aidera la France contre ces États, et si l'Angleterre en vient à une rupture avec les États, la France aidera l'Angleterre contre eux avec des forces dont on conviendra de part et d'autre.

Nul des deux rois ne prendra aucune nouvelle liaison avec les dits États généraux sans le consentement de l'autre, ni consentira à aucun partage des Pays-Bas espagnols à l'avantage des dits États.

Le roi de la Grande-Bretagne ne donnera aucun secours directement ou indirectement aux Espagnols, ni à aucun autre prince ni état, quel qu'il puisse être, contre les intérêts du roi de France, tant que les Espagnols auront guerre contre la France.

Le traité de commerce entre l'Angleterre et la France s'ajustera dans deux mois de temps après la signature du présent traité.

A counter project was proposed by Louis on the 4th of January I668; but in the meantime a rapid and decisive move had been gained by Arlington in the opposite direction. Sir William Temple had been to the Hague, and had concerted with De Witt the principles of the mediation by which the Dutch 
hoped to terminate the war: at the end of December he returned to London. On the Ist of January, the English Cabinet agreed to the proposition of a close alliance of mediation with Holland. Temple returned to the Hague on the 6th, and succeeded in obtaining from Count Dohna the concurrence of Sweden, a power which had been closely united to France ever since the Treaty of Oliva. M. Mignet asserts that De Witt still hesitated to abandon the ancient French policy of Holland for an alliance with England: we question the fact, for the crisis was one of infinite moment, and De Witt had already hesitated too long. Everything depended on secrecy and despatch. On the i8th Temple had his public audience; and on the 23 rd of January I 668 the Treaty of the Triple Alliance was signed. After sealing, says Hume, all parties embraced with great cordiality. Temple cried out, 'At Breda as friends; here, as brothers:' De Witt added, that now the matter was finished it looked like a miracle. Within a few days Van Beverning and Trevor were on their way to Paris, to negotiate with Louis for the peace. Charles II. announced the event to his sister, Madame, with consummate effrontery on the very day the Treaty was signed in the following letter :- 
I believe you will be a little surprised at the Treaty I have concluded with the States : the effect of it is to bring Spain to consent to the peace upon the terms the King of France has avowed he will be content with; so, as I have done nothing to prejudice France in this agreement, and they cannot wonder I provide for myself against any mischief this war may produce, and finding my propositions to France received so cold an answer, which, in effect, was as good as a refusal, I thought I had no other way but this to secure myself. If I find by the letters that my Lord St. Albans is come away, I do intend to send somebody else to France to incline the King to accept of this peace. ${ }^{1}$

We shall not enter upon the known conditions of this celebrated Treaty; and the extent of the materials before us forbids us to dwell upon the curious episode of the affairs of Portugal, which formed the subject of the secret articles annexed to it, although the ferocious caprices of Alphonso VI. might fill a curious page in the annals of Bedlam. The events of the last twelve months were now rapidly drawing to a close. Peace between Spain and Portugal was signed on the $13^{\text {th }}$ of February, and the independence of the latter kingdom permanently established. Louis XIV. condescended to no expostulations; but in the depth of winter he put himself at the head of the army of Burgundy, and confounded Europe by

1 This note was seen and copied by Sir J. Dalrymple in the dépôt at Versailles. 
the rapidity with which he snatched Franche-Comté from the feeble grasp of Spain. Satisfied with this new exploit, he then haughtily disposed himself to treat for peace, on conditions which a conqueror might have dictated, but which he affected to accept under the mediation of submissive Europe. His policy was even more triumphant than his arms. He had raised his fame to the highest pitch of greatness, and in the midst of his conquests he had paused to secure them. Even at that moment he hesitated to agree to the peace. A negotiation was on foot to engage the Duke of Savoy in the continuation of the war, and three armies were ready to re-enter the Low Countries. Louis consulted his generals and his ministers as to which was the most honourable and advantageous part to take,to adhere to his promises of peace, or to pursue the certain advantages of war. Turenne and Condé voted for war, Lionne and Colbert urged the nobler counsel, and Louis himself says in his memoirs :-

Je ne regardais pas seulement à profiter de la conjoncture présente, mais encore à me mettre en état de me bien servir de celles qui vraisemblablement pouvaient arriver .... et je remarquais que dans toute l'Europe je serais plus considéré et plus en pouvoir d'obtenir de chaque état particulier ce qui pourrait aller à mes fins tandis que l'on me verrait sans adversaire que 
quand il y aurait un parti formé contre moi. ${ }^{1}$-(Mémoires de Louis, vol. ii. p. 369.)

\section{Up to this period Louis had failed in nothing,} because he had never allowed his confidence in his military resources, great as they were, to induce him to risk a conflict with a force equal or superior to his own. His object was not to defy coalitions, but to dissolve them; and war became little more than the secure pastime of a gallant Court as long as it was directed by the cautious and penetrating genius of Lionne. As long as that great minister-the

1 It is worthy of remark, that in the paragraph immediately following these words, Louis mentions the treaty with the Emperor for the eventual partition of the Spanish monarchy as a consequence of his declaration that he was ready to accept the conditions of peace proposed by what he termed the 'complot' of the Triple Alliance. This assertion is totally erroneous. The Partition Treaty was signed at Vienna just three days before the Triple Alliance was signed at the Hague, and three months before the peace was signed at Aix-la-Chapelle. The whole negotiation at Vienna was concluded without the smallest su spicion on the side of the Austrian or the French ministers of what was passing in the north of Europe. The Treaty of Partition was regarded by the Court of Vienna as an inducement to Louis to make peace, because it secured to him the eventual possession of those very provinces in Flanders which he was about to conquer by arms; so that, far from being a consequence of the peace, it was one of the causes of it, both in point of time and of policy. It may be observed, that in the month of December I667 and January 1668 three negotiations of the first importance were simultaneously in progress : the abortive project of Ruvigny's Treaty between Louis and Charles ; M. de Gremonville's successful Treaty at Vienna; and the negotiation between De Witt and Sir William Temple. Europe was mined and countermined by the diplomacy of France, England, Holland, and the Empire; but it was the result of these several negotiations that determined Louis to accept the peace of Aix-la-Chapelle. 
greatest foreign minister, as it appears to us from these despatches, who ever held that office under the Crown of France-was alive, the passions of the young King never led astray his policy. After Lionne's death, the ascendancy of Louvois and the arrogance of unbroken prosperity shook the principles on which the foreign policy of the kingdom had been framed: the mad passions of conquest and revenge burned more fiercely in later years, as the obstacles to them became more numerous; and, by a just retribution, Louis saw the close of his reign overcast by the very dangers which he had at an earlier period been most sedulous to avoid.

The period at which we are now arrived is one in which the secret policy of the Court of France and the abject debasement of that of England have already been partially disclosed to the world, and recorded in the public annals of history by the notes and copies which Sir John Dalrymple was allowed, by the extraordinary liberality of the Duc de Choiseul and the Duc d'Aiguillon, to make in the archives then kept at Versailles, and now under the care of M. Mignet at the Foreign Archives in Paris. It is impossible, however, to collect from these English translations of papers, somewhat hastily selected at that time from the great mass of diplo- 
matic correspondence, so complete a view of these transactions as that which M. Mignet has now laid, in their original form, before the world. The inference from Sir J. Dalrymple's selections is, that the Duchess of Orleans played a most important, if not the first, part in the whole of the negotiations; and the conclusion of the Treaty of Dover is commonly attributed to her journey, and her influence with Charles. The truth appears to be that the affair was as much treated in London as in Paris, and that the personal intervention of Madame at the moment of signature was rather an act of courtesy to Charles than an essential part of the transaction.

Louis had assented with a politic compliance to those conditions of the Triple Alliance which Lord Bolingbroke has justly stigmatised as a compromise between the bully and the bullied; but he was already conscious that the sudden combination which had affected to withstand the progress of his arms was not the basis of a serious coalition. By Gremonville's Treaty he had secured the assent or the neutrality of the Imperial Court; and Lionne probably detected the fact, that Temple was the only man concerned in the Triple League who was entirely sincere. Within a few days after the 
signing of the Treaty of Aix-la-Chapelle, Charles said to Ruvigny, that he wished to 'faire une bonne liaison' with the King his master, and begged the French ambassador to make proposals. In the following July, M. Colbert de Croissy (the brother of Colbert the minister) succeeded the Marquis de Ruvigny with full powers to treat with the Court of London on the express stipulation of the abandonment of the Triple Alliance. M. de Witt had already proposed on his side to conclude a treaty with Louis XIV. for the purpose of compelling the King of England to surrender his claim to the supremacy of the British flag in the Channel; but Louis only used this overture to detach the English from their recent alliance with the Dutch, by communicating it to the Court of St. James's. As for Sweden, although that power had momentarily united itself to England and Holland, the traditions of the Thirty Years' War and of the Peace of Oliva, assisted by the largesses of the French ambassador, might at any time, and did in effect soon afterwards, bring her back to the system of France. When in the following year the ministers at the Hague, under the unflinching investigations of Sir William Temple, attempted to call Louis to account for infractions of the Treaty of Aix-la-Chapelle, the 'impertinence' was as 
loudly disavowed by Charles as it was resisted by Louis.

In England, however, the influence of Arlington still preponderated over the secret desires of Charles, and Louis saw that he had little to hope for from the master unless he could bribe or deceive the minister. In a despatch to Colbert of August 27 , I668, he says :-

Je vois bien dès les premiers pas de cette négociation, que votre voyage aura sur cette matière le même succès que les deux autres, à moins ou que les affaires du monde ne changent fort, ou que celui qui les a aujourd'hui en main de delà ne perde quelque chose de ce grand crédit qui les lui fait conduire avec une autorité comme absolue, selon son caprice et ses inclinations plutôt que dans les véritables intérêts de son maître.

A la vérité, je ne puis pas me plaindre de sa sincérité, car il ne pouvait vous parler plus clairement qu'il a fait ; un plus habile homme que lui aurait caché longtemps ses sentiments, vous aurait amusé d'espérances et vous aurait tendu, c'est-à-dire, à moi, des piéges plus dangereux du côté des Hollandais; mais il n'a pas voulu ou su faire que je pusse douter un moment de sa mauvaise volonté et de l'aversion invincible qu'il a à laisser unir les intérêts des deux royaumes.-(Vol. iii. p. 45.)

Dalrymple asserts that, 'in the summer of the year i668, Charles frequently renewed the attempt to conclude a treaty with France; but France seems to have stood off, distrusting his sincerity.' Nothing can be more inaccurate; it was the French Court which most ardently desired the treaty, for its policy was 
arrested until this essential preliminary was accomplished; but the advances of Colbert were coldly received, and Charles was still afraid, except in his letters to his sister, to express his real wishes. On September 2 he writes to her thus :-

Mes dispositions sont toujours les mêmes, et j'espère finir par arriver en tout à ce que je veux; mais il y a sur la route deux empêchemens, dont le moindre résultat est de retarder les effets de la bonne envie qu'auraient les deux parties d'en venir à une union parfaite. Le premier est le grand soin que l'on se donne maintenant en France pour se créer un commerce, et pour être une puissance maritime imposante ; c'est un si grand sujet d'ombrage pour nous, qui ne pouvons avoir d'importance que par notre commerce et par nos forces de mer, que chaque pas que la France fera dans cette voie perpétuera la jalousie entre les deux nations. Ce sera un grand obstacle à l'établissement de relations tout-à-fait amicales, et vous ne pouvez vous refuser à croire qu'il sera trèsdangereux pour moi de faire ici un pacte d'union absolue avec la France jusqu'à ce que le premier de nos intérêts, c'est-à-dire celui de notre commerce, ait été garanti. L'autre difficulté gît dans les traités que j'ai faits récemment et que le roi mon frère ne voudrait pas, j'en suis sûr, me voir enfreindre, sous aucun prétexte, lui qui m'a montré par son bon exemple comment on est martyr de sa parole. Quand je dis cela, cependant, je ne nous crois pas tellement enchaînés ici que, si nous recevions satisfaction sur les points relatifs à la mer, il n'y ait jour suffisant à faire une étroite alliance. Je suis décidé, puisque mon inclination m'y porte, à faire tous mes efforts pour cimenter cette union.

At one moment the negotiation was resumed by the Duke of Buckingham; at another it was in the hands of the Duchess of Orleans and Sir Elias 
Leighton, without the privity of Colbert, the ambassador. Amongst the strange expedients which were used to promote the 'great affair,' was one altogether new in diplomacy. A taste for alchemy and astrology was one of the pursuits common to Charles and his favourite Buckingham; and it occurred to Louis and Lionne to avail themselves of the reputation and influence of a certain Abbé Pregnani, a great fortuneteller of the time, to strengthen their hold upon the King of England. The Abbé in his new capacity was described by Lionne in a despatch to Colbert as-

une personne affidée et d'esprit capable, entrant à toute heure dans ses divertissements et ses plus secrètes occupations, où votre caractère ne vous laisse pas admettre; et que vous pussiez vous servir de cet homme pour faire insinuer les choses que vous n'auriez pas occasion de dire, ou qui même seraient mieux et persuaderaient davantage étant dites par un tiers; être ponctuellement averti de tout ce qui se passe; et enfin employer cette sorte d'émissaire comme la main et l'instrument qu'elle met à l'usage qu'elle veut, et si elle ne veut, à rien.

The first stroke of the astrologer was a lucky one : the Duke of Monmouth consulted him on an affair of gallantry with so good a result that the King, being apprised of it, ordered him to take his mystic volumes to Newmarket to draw the royal horoscope there. Charles found the wizard ingenious and amusing. In a letter to his sister he says :- 
Pregnani will tell you more about it, for he has been almost all this time at Newmarket; but what he will not tell you is, that he has lost his money by trusting to the stars to tell him what horses would win. He was so unlucky as to make three predictions all wrong, and James [the Duke of Monmouth] who gave into them has also lost his money in the same scrape. (Vol. iii. p. 80).

The Abbé was not more successful in diplomacy than in racing. His presence offended Buckingham, who wished to keep the negotiation in his own hands, and Louis soon afterwards recalled him.

A fresh and much more serious impulse, however, was given to the affair by the conversion of the Duke of York in the spring of 1669 ; and thenceforward the re-establishment of the Romish religion, or at least the declaration of Charles and his brother's reconciliation with Rome, formed an important part of the negotiation. This point was concealed from Buckingham and Colbert de Croissy, and the correspondence was carried on by Lord Arundel and Lord St. Albans, who went to Paris ; but the most important change was the accession of Lord Arlington himself to the French party, of which he, the founder of the Triple Alliance, had till then been a strenuous opponent. The following letter to the Duchess of Orleans, which appears to have been written in French, contains his recantation:-

VOL. I. 
Si votre altesse royale se plaint de la généralité des termes de ma lettre, j'ai bien plus de raison (avec soumission) d'en faire autant de la particularité des termes de la sienne, et assurément ses correspondants dans cette cour me doivent avoir mal dépeint à votre altesse royale ; autrement elle n'aurait jamais songé à me traiter de la sorte. J'ai été toute ma vie bon serviteur.du roi mon maître, et mourrai ainsi par la grâce de Dieu; et pour tout le bien du monde ne ferai jamais autre figure que celle d'un bon Anglais. Avec tout cela, le roi me fera témoignage qu'en deux ou trois jonctures remarquables, j'ai plaidé le parti de la France plus fortement qu'aucun de ses ministres ; mais c'était lorsque je croyais que leur amitié lui pouvait être la plus utile. J'ai fait de même en d'autres pour l'Espagne et pour la Hollande, quand la même raison semblait m'y obliger, mais toujours (Dieu merci) sans en prétendre ou recevoir aucune utilité pour moi-même. Voilà en vérité, madame, comme je suis fait, et, si un homme comme cela peut être agréable à votre altesse royale, je la supplie très-humblement de m'accepter en qualité de son très-humble et très-obéissant serviteur, qui vous honore avec une vénération profonde pour être la bien-aimée sœur de mon maître, et, à ce que je crois fermement, la princesse du monde la plus accomplie. Je pourrais ajouter à cela l'intérêt que j'ai à bien servir son altesse royale, sachant à quel point le roi vous aime et quel état il fait de votre amitié. Je finirai la présente en faisant souvenir votre altesse royale que sa majesté a eu la bonté de répondre pour moi, et qu'ainsi toutes autres cautions ne seraient pas seulement superflues, mais dérogeraient fort à la caution royale que vous avez déjà reçue pour moi.

(Signé)

ARLINGToN.

If, in the whole course of these shameful transactions, the name of one English minister deserves to be branded with deeper infamy than all the rest, it 
is that of the writer of this letter. Buckingham was at least consistent in his profligate servility, and Arundel in his bigotry ; but for the Secretary-of-State, who had forced the King into the Triple Alliance, and who still kept Temple at the Hague, to put his hand to this counter-plot was a treachery without a parallel. It does not, however, appear that Arlington was gained by money. Louis had caused magnificent bribes to be offered him, but they were refused; and upon the signing of the Treaty he only received a present of 8,000 crowns, with the sanction and by the desire of his master; to which was added a pearl necklace, worth 60,000 livres, for Lady Arlington on the declaration of war.

Our limits forbid us to enter at length into the curious conversations of the French Ambassador with Charles on his projected change of religion, and on the state of religious parties in England, but they deserve to be recorded as matters of first-rate historical interest. The increasing necessities of the King, and the increasing, bigotry of his brother hastened the progress of the treaty, and on December I8, I669, the scheme was drawn up by Sir Richard Bellings and communicated to Colbert. ${ }^{1}$

1 See Dalrymple's Memoirs, vol. i. p. 96 (octavo edition). 
The first demands of the English Court are well known : Charles was to receive 200,000 . on declaring himself a Catholic; Louis was to assist him with troops and money in case of a rebellion in England; the peace of Aix-la-Chapelle was to be maintained during the life of the King of Spain; but at his death England was to have Minorca, Ostend, and Spanish America, and Lours the rest of the Spanish dominions,-a second treaty of partition being thus entertained by the French Court and with another power within two years of the conclusion of M. de Gremonville's Treaty at Vienna ;and war was to be declared against the United Provinces by sea and land, and, at the especial desire of Charles, against Hamburg, from commercial jealousy. A stipulation was added in favour of the interests of the Prince of Orange, which was admitted into the final treaty.

The various points contained in these articles were fully debated in London between Colbert, Arlington, Arundel, and the King. The amount of the donation was reduced to 2,000,000 livres; the stipulations as to the eventual partition of the Spanish dominions were postponed; the command of the fleet, consisting of fifty English and thirty French vessels, was given to the Duke of York; 
Charles was to receive an annual subsidy of 3,000,000 livres during the war, and was to keep, when conquered, the islands of Walcheren, Cadsand, and Helvoestsluys : the war against Hamburg was abandoned. At the last moment Charles urged his extreme desire of seeing his sister in England. With great difficulty the Duke of Orleans, who was jealous of his wife's political importance, was brought to consent to her journey. The Princess came to Dover. The negotiation was already completed, and all that remained for her to obtain was, that the declaration of war against Holland should not be postponed to the declaration of Charles' conversion, and that the period fixed for the exchange of the ratifications should be abridged. In the latter respect she succeeded, and on June I, I670, the Treaty was secretly signed by the Roman Catholic members of the Cabinet, without the privity of their colleagues : time and the questionable religious zeal of Charles decided the other difficulty.

It will be observed that Sir John Dalrymple did not see the original treaty at Versailles, and that all the historical writers who have used his materials have fallen into the very serious error of mistaking the proposal as it was drawn up by Sir R. Bellings on the part of England, for the conditions of the treaty 
itself as they were finally adopted, with great modifications, by both Courts. ${ }^{1} \quad$ The act is given at full length in the volumes before us.

We are unwilling to deviate from the more precise object of these pages to enter into the history of the suspicions awakened by the sudden death of the Duchess of Orleans, or the discussions which arose on the interpretation and fulfilment of the articles of the treaty. These details, and the manœuvres which were contrived to engage the Duke of Buckingham and the Protestant ministers of the crown of England in the simulated treaty (which

${ }^{1}$ See the Pictorial History of England, vol. iii. p. 707. Dr. Lingard, however, gives a copy of the Treaty from that in the possession of Lord Clifford, which is the original. We have ascertained that the Treaty does not exist in the State-paper office ; for greater secrecy it probably remained in the custody of Sir Thomas Clifford, and is still amongst the papers of his family. It is asserted by all the historians, that the French original has been lost : this is an error, it is in the Depôt of 'Treaties.

It is not surprising that Hume's knowledge of the conditions was not very accurate, since it was only derived from a cursory perusal of James II 's Memoirs, kept in the Scots' College at Paris, after the first edition of his work had appeared. But it is remarkable that so recent a writer as Sismondi should have fallen into still greater errors (Histoire des Français, t. xxv. p. 195). Sismondi appears to have followed Flassan (Diplomatie française, t. iii. p. 386), though Flassan at the time his work was published could have had no access to the Treaty itself. The chief mistake is in the amount of the subsidy, which was reduced from 200,000l. to two millions of livres. All these writers have also been led to ascribe an undue importance to the journey and intervention of Madame and her pretty attendant, the future Duchess of Portsmouth. 
was almost a counterpart of the one already concluded, omitting the conversion of the King), belong more properly to English history. This last notable contrivance originated with Charles, and the French Court assented to it with some reluctance. Lionne observed:

Ce que l'on considère ici pour plus fâcheux c'est sur l'issue de l'affaire, savoir s'il faudra à la fin découvrir la vérité et avouer à des gens qu'on leur aurait fait jouer la comédie, et même un personnage très-fâcheux de Coigne-fest qui pense, comme décrit le chevalier de Jacas, avoir fait le Pont-Neuf, et n'y a pas mis une pierre.

There is nothing in history marked with a finer vein of comedy than the ostentatious servility of Buckingham in the negotiation of a treaty which had already been concluded and signed by the very man he was most anxious to thwart and to surpass. The expedient was worthier of a farce than of the alliance of two nations. But the eagerness with which Louis had pursued this negotiation, and the prodigality with which he had purchased its conclusion, were not to be checked by any obstacle. He was intent on the prosecution of his aggressive policy, to which the assent of England was an indispensable condition; and the treaty was brought about, not so much by the weakness of Charles as by the determination of Louis. 
In the meantime M. de Witt was not altogether unconscious of the dangerous position in which he stood, although he could not foresee the extent of his peril or measure the intensity of an hostility which still wore the mask of such consummate dissimulation. In both the first wars of Louis, against Spain and against Holland, not a sign of an offensive movement was made by the French forces until the designated victim had been singled out and cut off from the family of nations, and stood unassisted by a single ally to encounter the whole fury of the war. By negotiations, accompanied for the most part with bribes to the ministers of the respective courts, and with the promise of large subsidies to their masters, not only was England engaged to take an active part in the projected campaign, but the Princes' and Dukes of Cologne, Münster, Hanover, and Osnabrück were pledged to facilitate the passage of troops ; and Sweden, the third party to the Dutch alliance, had been bought over by the promise of an annual subsidy of 600,000 crowns to lend herself to the vast conspiracy, by engaging to send an army of I6,000 men to the north of Germany to attack those states which might be disposed to assist the United Provinces.

The state of the relations between the Courts of 
St. Germain and Vienna at this time demands a closer notice. On either side the Treaty of January I668 was still held to be in full force. The Emperor was induced by $M$. de Gremonville to refuse his ratification to a treaty, unfavourable to France, which had been concluded with Sweden; Louis withheld the countenance which he had given on former occasions to the Hungarian insurgents. At this juncture the Imperial Cabinet, with more address than it had before displayed, proposed to Louis a Triple Alliance of the Catholic powers of the south, France, Austria, and Spain, to counterbalance the Triple Protestant League of the north of Europe. It required more than the usual art of Lionne to evade so politic and logical a proposal; yet to accept it, and to form a direct alliance with Spain, was to postpone indefinitely the coveted occupation of the rest of Flanders.

Tout le but du mémoire (said Louis in his private despatch to Gremonville) ne tend qu'à me lier les mains sans que j'en tirasse aucun avantage, et à procurer aux Espagnols le plus grand qu'ils puissent désirer; car, par le moyen que l'on propose, ils seraient assurés de demeurer en paix jusqu'à la majorité de leur roi, ou jusqu'à ce qu'ils eussent trouvé un temps auquel, leurs affaires étant en meilleur état, et leurs parties mieux faites, ils croiraient d'avoir toujours d'assez justes sujets de rompre avec moi. Cependant tout le fondement ou le prétexte de ce grand avantage qu'on veut procurer à l'Espagne n'est autre que de faire craindre l'état 
où les affaires pourraient se trouver quand le cas du traité secret arriverait, et toute l'utilité que j'en recevrais ne serait que dans l'imagination.

At the same time, it was obviously of vital importance to prevent the Emperor from joining the Dutch Triple Alliance; and, in order to occupy the attention of the Austrian ministers, Louis put forward a scheme, which had been somewhat loosely adopted by certain members of the Council of Castile, for surrendering the whole of Flanders to France in exchange for certain advantages nearer home, and, in particular, upon the condition of abandoning Portugal to be reconquered by the house of Austria.

This proposal, however, was coldly received at Vienna; and a few days afterwards intelligence was received that the life of the young King of Spain was despaired of. It seemed that no time was to be lost in preparing for the great emergency. Don Juan of Austria, the natural son of Philip IV. and the favourite of his father, already assumed the air of a pretender to the succession. He boldly left Consuegra, and retired to Aragon, whence he proceeded to the gates of Madrid, where his presence sufficed to cause a revolution and reduce the regency to the verge of dissolution. Viva el Rey Don Fuan! and 
Muera el mal gobierno! were the cries already heard in the capital. The Cabinet of France was prepared to publish the secret Treaty of Partition. To the daring proposals of M. de Gremonville, Prince Auersperg could only reply, like a timid accomplice trembling at the detection of his share in the robbery of an orchard, 'Per l'amore di Dio teniamo il trattato celato.' Austria foresaw that if the whole treaty were avowed, Europe would rise with one common accord against her; and even in Spain the party of Don Juan was sufficiently strong to defy the claims of Leopold on such ignominious terms. But Don Juan lost his opportunity,- he did not enter Madrid at the critical moment,- and the recovery of the King restored the authority of the Queenregent. The danger was past for the time, but the fears of the Spanish Government, and their efforts to detach the Court of Vienna from the influence of France, were redoubled.

The situation of the French ambassador became extremely difficult. Prince Auersperg, who had been disappointed of his promised cardinal's hat, which was given to a nephew of Turenne, quarrelled with Gremonville; and Prince Lobkowicz, who shortly afterwards succeeded Auersperg, was far less prone to the French policy. Yet it was becoming neces- 
sary to disclose to the Imperial Cabinet the designs of Louis against Holland, in order to secure its neutrality; and for this purpose to communicate, though in a very incomplete and inaccurate statement, the fact of the alliance already concluded with England. An unsuccessful attempt was made to sound the Austrian ministers as to the possibility of admitting England to share in the Treaty of Partition,_L Louis himself having such a treaty with both those Powers. But if Louis had swerved from his engagements with Leopold by some of the stipulations of the Treaty of Dover, the Emperor on his side had violated his engagements by giving the Spaniards a written promise that he would not again abandon them, and would even, if necessary, join the Triple League. The scene which followed this discovery deserves to be quoted in the words of M. Mignet.

Lorsque le chevalier de Gremonville connut cet accident il se rendit auprès de l'empereur, lui rappela pathétiquement les soins qu'avait pris le roi pour le maintien de leur union, les promesses qui lui avaient été faites par ses ministres, les assurances qu'il arait constamment données lui-même, le dédain avec lequel on avait traité les démarches de l'Isola, qu'on appelait visionnaire, et qu'on disait 'abandonner aux Espagnols comme une poupée aux enfans ;' puis il ajouta : 'que le roi son maître avait été étrangement surpris, après tout cela, d'apprendre la vanterie que faisaient les Espagnols, d'avoir obtenu de lui, depuis si longtemps, une parole par écrit, de laquelle ils faisaient même voir le contenu.'

'Je n'eus pas lâché le mot,' écrivit le chevalier de Gremonville 
Louis XIV, 'que l'empereur devint pâle comme un mort, ce qui m'aurait assez fait découvrir la vérité, si je ne l'avais sue d'ailleurs.' Il feignait de ne pas y croire, dit que ce serait la plus horrible contravention aux paroles données et au traité secret, et obligea l'empereur à de nouvelles protestations.

This proceeding of M. de Gremonville, which was worthy of the arrogance of his master, succeeded. He found himself master of the field. The language of Louis himself was equally imperious in a despatch which the envoy translated into Italian and read to the Emperor word for word.

Ce sera à l'empereur à choisir s'il veut, ou que je demeure son bon ani, ou que je prenne d'autres mesures; je ne vous célerai pas même que je souhaite fort qu'il prenne plutôt le premier parti que le second; mais quand je fais ce souhait, je puis dire sans vanité que c'est bien plus par l'amitié et la tendresse que j'ai pour sa personne que par aucun motif d'intérêt. Il peut bien arriver qu'on me fasse du mal, personne ne doit s'en croire exempt en ce monde ; pour de la peur, on ne me la fera pas assurément, et rien ne sera capable de me faire commettre une bassesse ou une indignité ; aussi bien, plus j'aurai d'affaires, plus j'aurai de gloire, si je sais m'en tirer heureusement; et qui a de bonnes troupes et de l'argent pour en avoir, dans un besoin, quatre et six fois autant, doit, à mon sens, se mettre bien plus en peine de n'avoir pas matière d'employer et ces troupes et cet argent, qu'il ne peut être fâché que d'autres lui fournissent cette matière, et particulièrement quand on y peut acquérir de la gloire.

The Chevalier declared that he had never seen the imperial attention so excited as whilst he was reading these extraordinary sentences to Leopold :- 
Il ouvrit fort les yeux, et par conséquent les oreilles, sur la proposition que votre majesté faisait de lui laisser le choix du parti d'être son bon ami ou de ne l'être pas; et à peine eusje achevé l'endroit qui contenait le plaisir que votre majesté aurait qu'il acceptât le premier, il me dit, avec un visage riant, et une marque de beaucoup de tendresse, ces paroles: 'Anche noi prendiamo volontieri il medesimo partito, sperando che qual si voglia incidente non ci potrà dividere.' Je lui répliquais que cette seule déclaration suffirait à votre majesté pour la persuader qu'il ne s'engagerait jamais en rien contre ses intérêts, quand d'ailleurs les siens et ceux d'Espagne seraient à couvert. Il me répliqua, 'Avremo sempre questa intenzione.'

Such were the two sovereigns of Germany and France!

These altercations threatened not unfrequently to rise into personal violence between the ministers of the two countries, and Gremonville had at times almost as much need of his sword as of his pen. 'For the last week,' says he in one of his letters to the King, 'I have been in so violent a negotiation that I may say that no enterprise or action of war, during the four and twenty years that I was engaged in it, ever caused me so much labour of mind and body.' The Empress-mother, however, had allowed herself to be bribed. The Emperor himself, incapable of taking a politic view of the affairs of Europe, was ready enough to sacrifice the Dutch to the anger of Louis, so long as the Spaniards were 
not attacked; and on November 1, 1671, another treaty was concluded between the Courts of France and Austria, by which the former bound itself to maintain the peace of Aix-la-Chapelle with Spain, and the latter agreed to withhold all assistance from the three members of the Triple League, or any one of them, if attacked by Louis. We have already seen, that at this very time, or shortly afterwards, secret treaties had been concluded between France and England, and France and Sweden, so that in fact Holland alone was implied by this stipulation.

The period of three years which Louis and Lionne had assigned to their diplomatic operations was drawing to a close, and everything was prepared for the declaration of war in the spring of 1672 . What then was the position of Holland?

Upon looking with attention to these widely extended transactions, which may now be better known to the reader of the volumes before us than to the greatest statesmen at the period in which they occurred, we are irresistibly led to a strong, though perhaps a somewhat singular opinion, that that Triple League, which has been so generally extolled as the triumph of Temple and De Witt, was a great and fatal diplomatic error. We have at present no evidence that, in the whole course of the ten years 
during which Lionne directed the foreign affairs of France, any equal error was committed on the side of Louis or his advisers. The League with Holland was hailed with the greatest enthusiasm in this country, because it was believed to be calculated to check the dangerous propensities of Charles and the formidable designs of Louis: thus perhaps it has retained from tradition a lustre which might be denied it by truth and reason. As a means of controlling the military progress of Louis, the League was wholly ineffectual. During the winter of $\mathrm{r} 668$, it rather prompted than prevented the irruption into Franche-Comté ; and the conditions of the ensuing peace were no other than those which Louis had already expressed his readiness to accept. The war of devolution and the pretensions of Louis were indeed enough to have startled all mankind into one firm and compact alliance of defence; but in our own time, when the relations of states are less perplexed by fraud and corruption, have we not seen that not one campaign, nor the ruin of one nation, but the impending, if not actual, servitude of the whole of Europe were needed, before the conquests of Napoleon brought about a serious and effectual coalition of his victims and his antagonists? Sir W. Temple doubtless felt the necessity of such a com- 
bination, but the machinery he put in motion was far too slight. Even at home he knew not that the $\mathrm{King}$, in whose name he was acting, was at that moment personally negotiating on the other side, and that the minister under whom he held his instructions was ere long to sign the Treaty of Dover. Far from being the nucleus of a grand coalition, the Triple League had within itself no principle of strength, unity, or permanence. It was a mere compromise with a successful enemy, and it surrendered the whole question of right and the whole stringency of the renunciation.

Temple may have deluded himself, but the error of De Witt was more fatal. If, as was the case, he felt that the existence of his country required that great change in her foreign alliances which his disinterested patriotism led him to accomplish, he ought to have provided against the possibility of exposing the isolated interest of Holland to the vindictive fury of France. What reliance could he place on Charles II., or on the ponderous intriguers of Stockholm? England and Sweden had little to risk,-their interest in the whole question was secondary; that of the United Provinces involved their national existence. The real basis therefore of an alliance for the purpose of resisting Louis should VOL. I. 
have been laid between Holland and Spain. De Witt knew enough of the designs of Louis to be aware that he claimed the whole of Flanders, at any rate, as his share of the spoils of the Spanish monarchy; and well would it have been for Holland if, instead of allowing the projects of Louis to grow to full maturity, the Grand-Pensioner had answered the call of the Marquis de Castel-Rodrigo in 1667 , and dared at once to confront a policy which nothing but weakness and terror could sanction. If this course was beyond his strength, he should at least not have assented to half measures, which drew on his country the whole resentment of Louis, and scarcely purchased for the States the appearance of a temporary security.

Even the Dutch ministers most hostile to France were conscious of the extreme difficulty and danger of their position. In September I669 the French ambassador at the Hague writes thus :-

Le monstre de la triple alliance me paraît perdre de jour en jour quelque partie des forces que l'illusion commune lui avait attribuées, et je ne sais si c'est dans la vue des fausses mesures que cet état a prises, que, parlant il n'y a pas longtemps à M. Van Beuninghen des anciennes maximes que l'on a ici abandonnées en s'éloignant de la France, il me dit qu'il voudrait avoir donné un doigt et qu'il fût en leurs mains d'y revenir. Il entendait par lì ce que l'on me dit ici tous les jours, que la France a quitté tous les sentimens qu'elle a eus autrefois pour cet état ; qu'elle ne veut plus de concert et de liaison avec lui. 
Six months before, the same minister had used the following remarkable language to De Witt himself :-

Si j'étais Hollandais je pourrais bien voir avec peine la situation de cet état, mais je n'en changerais point les anciennes maximes qui l'ont établi ; je pourrais bien regarder avec inquiétude la puissance si voisine de la France, mais je verrais avec une bien plus grande crainte les moyens de m'en garantir ; ne pouvant éloigner la France, et ne pouvant lui opposer que l'Espagne, l'Angleterre et la Suède, j'envisagerais comme un bien moindre péril de me confier à un allié dont j'ai toujours éprouvé l'affection et les assistances, que de m'abandonner à des puissances, les unes irréconciliables, les autres souvent ennemies, et quelques-unes nouvellement offensées. M'accommodant à une disposition du ciel que je ne pourrais changer, je préférerais un moindre danger à un plus grand, et un ami puissant et éprouvé à des ennemis réconciliés et toujours suspects.

M. de Witt avoua, avec quelque amertume, que les ÉtatsGénéraux ne sauraient compter sur leurs nouveaux alliés. Il entra même dans la haine qu'ils se doivent toujours attendre de l'Espagne, dans le peu d'amitié qu'ils se doivent promettre de la Suède, et surtout dans les occasions toujours proches où ils sont d'un démêlé avec l'Angleterre. Il ne les faisait pas consister seulement dans l'intérêt du commerce, mais autant, pour le moins, dans celui du pavillon.

Holland was formidable to Louis, not by her allies but by herself. She was the watch-dog of Spain; and although the United Provinces were destitute of military resources even to defend their own cities, they were inferior to no other nation in their navy, they were superior to all in their finance; and this power, united to the troops of Spain, might still 
have disputed the ascendancy of Louis in Europe, as was afterwards shown when the political genius of William III. directed the combined forces of Holland and England.

The year I67 I marks the culminating point of the diplomatic genius of the cabinet of Louis. In subsequent years he may have been more formidable and more powerful; but the risks of his exalted position were frightfully multiplied, and more than once some excess of arrogance or tyranny robbed him in the moment of success of the fruits of his stratagems and his wars. But in this same year the presiding genius of the foreign policy of France and the great pupil of Mazarin expired. M. de Lionne, who for nearly forty years had taken an active part in the greatest affairs of state, and for the last ten had governed the diplomatic relations of Europe, died on the ist of September I67I in the midst of those pleasures to which he was not less devoted than to the vast duties of his master's service. $^{1}$ Neither in the memoirs of the time, nor in more recent history, has this eminent statesman received that share of political renown which

1 Madame de Lionne, 'veuve,' as St.-Simon calls her, 'du plus grand ministre de Louis XIV', died many years after her husband, in extreme indigence. The family of the minister was ruined and dispersed, partly by their own misconduct, partly by the total neglect of the King. 
he in reality rather imparted to the reign of Louis than derived from it. His own despatches have at length avenged him of the ingratitude of his contemporaries and the indifference of posterity. Upon very insufficient grounds M. de Turenne has often received the credit of one of the principal political counsellors of the King, although in these volumes there is no intimation that he was privy to the most important secret transactions of the reign. On still more inadequate grounds, the name of the Marquis de Louvois has been indissolubly connected with the great actions of Louis, although the only real services he rendered to the State-services very disproportioned to his numerous and incurable errors-were performed in his capacity of a military administrator. The real author of the system of the foreign policy of France was, after Mazarin, Lionne. The inflexible will, the unscrupulous ambition, and the indefatigable industry of the King still pursued an unwavering course; but the prudence that restrained him, and the subtlety which evaded every obstacle, were not to be supplied by inferior men.

The Marquis de Pomponne was summoned in October $167 \mathrm{I}$ from Stockholm, to assume the important duties of Foreign Secretary in France. ${ }^{1} \mathrm{M}$.

1 Pomponne was only known to Louis by reputation and by the ability he had shown in various embassies. The appointment was 
de Pomponne had been sent to the Hague by Lionne himself in 1669, as one of the ablest diplomatic servants of the Crown; and he had acquitted himself with great dexterity of the task of amusing M. de Witt, by apparently favouring the decided advances of that statesman to France, whilst in fact the whole balance of power in Europe was in the act of turning against him. It was at this period that the report of Van Beuninghen's celebrated medal of Joshua stopping the sun was first circulated, with all those additions and imputations which Louis afterwards revenged with such implacable ferocity. Van Beuninghen hastened of his own accord to protest to the ambassador his entire innocence of any intention to affront the King. Lionne's

universally approved. 'Mais l'emploi,' says Louis himself, 'que je lui ai donné s'est trouvé trop grand et trop étendu pour lui. J'ai souffert plusieurs années de sa faiblesse, de son opiniâtreté, de son inapplication. Il m'en a coûté des choses considérables; je n'ai pas profité de tous les avantages que je pouvais avoir, et tout cela par complaisance et bonté. Enfin il a fallu que je lui ordonne de se retirer, parceque tout ce qui passait par lui perdait de la grandeur, de la force qu'on doit ${ }^{\cdot}$ avoir, en exécutant les ordres d'un roi de France qui n'est pas malheureux.' (Flassan, vol. iii. p. 473). The immediate cause of Pomponne's disgrace was the circumstance of his having kept in his pocket, whilst he went into the country for some days, a despatch which the King was anxious to see. He was succeeded after the Peace of Nymeguen by Colbert de Croissy, of whom Charles II. at least entertained a very mean cpinion during his residence in London-a judgment which the publication of his despatches tends to corroborate. 'The Marquis de Torcy, the last foreign minister of Louis, was his son. 
reply is curious, when it is recollected that this very incident was converted a few months áfterwards into one of the alleged grounds of the war :-

J'ai rendu compte au roi de tout ce que M. Van Beuninghen vous a dit sur le sujet de la prétendue médaille de Josué. Sa majesté l'a eu fort agréable, et a dit qu'elle l'avait trouvé et éprouvé si habile homme, qu'elle ne jugerait jamais qu'il eût été capable de commettre une si grande et si téméraire extravagance, et qu'ainsi il ne doit point se mettre en peine que tous les faux bruits qui ont couru aient fait aucune impression sur son esprit.

In proportion as the cabinet of Madrid discovered that the aggressive designs of Louis were diverted from its own provinces to those of Holland, it relaxed in its efforts to avert them; though as M. de Lionne had himself observed in one of his letters, 'As they have only to look for the favour of the Cyclops, to be eaten last, they are strangely embarrassed.' The increasing danger of the States appeared to close every channel of assistance from without; and to complete the perplexity of De Witt at this crisis, the power which he had exercised in the foreign affairs of his country for several years, with an undivided authority, was now weakened by the entry of the young Prince of Orange into public life and into the council of State. The recall of Sir William Temple from the Hague, which took place soon after the signing of the Treaty of Dover, had 
confirmed De Witt's suspicions of the secret intelligence between England and France. 'If I return,' said Temple on leaving his illustrious friend, 'you shall know more; if I do not return, you will know all.' The Dutch Government continued to arm ; but M. de Groot, a son of Hugo Grotius, was sent on an embassy to St. Germain especially charged with the defence of the commercial interests of the States. The answer of Louis was repulsive, and he continued to load the Dutch trade with excessive imposts. De Witt was on the horns of a dilemma, in which his policy and his personal safety were both involved. If he openly resisted the Prince of Orange, all hope of assistance from his uncle the King of England was cut off; if he gave way to William, he was himself irretrievably ruined in the Provinces. At such a moment, it is to the honour of De Witt that he did not sacrifice his policy unconditionally to the demands of Louis, and propose to abandon the Spanish Provinces of Flanders and the whole principle of the Barrier. But it is questionable whether even that unconditional surrender would then have satisfied the implacable King, who already treated their preparations for defence as 'les fanfaronnades de ces pêcheurs.'

M. de Beverning, who, in spite of his pedantry 
and his drunken habits, was the most successful of diplomatists, since he is said by Bayle never to have failed in any negotiation, had been sent by De Witt to Madrid. He found that Court in strange confusion, and the most influential person in it was a favourite dwarf of the Queen-regent, through whom Her Majesty retailed to the highest bidder the great offices of State. The French ambassador, supposing from what he had witnessed that the Spanish monarchy was to be sold in lots and by auction, was commissioned by Louis to offer to purchase Flanders; and Gremonville was ordered to promise 2,000,000 livres to the Emperor and one million to Lobkowicz, if they would assist and ensure the sale. But this proposition was not entertained at Madrid, however it might be approved at Vienna.

It was not, however, till December 17, 1671, that an engagement was entered into-not at Madrid but at the Hague-between the Spanish ambassador and the States, for the purposes of mutual defence against Louis, - an engagement which, in spite of the joint and vehement exertions of Louis and the King of England at Madrid, was secretly ratified. This occurrence is of the utmost moment. Up to that time the Dutch stood alone, but this declaration identified their interests with those of Spain, and 
prepared those great changes which supervened in the course of the war. By this decision of the Spanish regency, the Court of Vienna was already shaken : and it must be added that the Elector of Brandenburg was pledged to the assistance of the States-a contingency which M. de Lionne had foreseen when he prepared the diversion which was to be made by Sweden. Nothing in the meanwhile could exceed the humility of the Dutch envoy in France; but to his supplications for peace Louis returned a terrific reply :-

Quand j'ai appris que les Provinces-Unies essayaient de débaucher mes alliés, et sollicitaient des rois mes parents d'entrer en des ligues offensives contre moi, j'ai voulu me mettre en état de me défendre, et j'ai levé quelques troupes; mais je prétends en avoir encore plus vers le printemps, et je m'en servirai en ce temps-là de la manière que je jugerai le plus à propos pour le bien de mon état et pour ma gloire.

(Signé)

Louis.

Even to England the United Provinces were prepared to make any concessions. They declared they were ready to give up the entire question of the flag, and that a whole Dutch fleet should salute a single British man-of-war, or the least even of the King's yachts, provided the King of Great Britain would ensure the fulfilment of the fifth article of the Triple Alliance in case they were attacked by France. Neither on the side of France or of England 
was there a shadow of ground for the war; and Charles recalled his minister Downing, lest there should be nothing left for him to demand. He had already received considerable instalments of the subsidy, both for his conversion and for the war; and Louis completed his satisfaction by allowing him to reduce the contingent of English troops from 6,000 to 2,400 , who were placed under the command of the Duke of Monmouth. On March 29, 1672 (after the notorious attempt upon the Smyrna fleet), war was declared in London. A treaty between the two crowns, destined to be made public, had been signed by Colbert de Croissy and the whole Cabal Ministry on February I2. The French declaration of war was made in solemn form on April 6, and soon afterwards the operations of the campaign began.

Our limits remind us that a narrative of the events of the war forms no part of the diplomatic history of the reign of Louis. We have shown the persevering ability with which the fundamental idea of the acquisition of Flanders was pursued by the Court of France; and it is not too much to assert that, throughout the preliminary negotiations and operations this was the paramount object, to which every other incident was subordinate. The 'frontier of the 
Rhine,' to use the more modern appellation, which is applied in our day to the same political object, was ever before Louis and never permanently attained. After the Peace of Aix-la-Chapelle, the doctrine of the French Cabinet was, to use their own words, that 'the true means of succeeding in the conquest of the Spanish Low-Countries was to humble the Dutch, and, if possible, to annihilate them.' ${ }^{1}$ The war with Holland, which has commonly, if not universally, been regarded as a wanton aggression, or at most a violent act of revenge, was in reality a profoundly combined measure tending to that ulterior object which the policy of De Witt had on a former occasion frustrated.

We shall not recapitulate the well-known events of the war, which swept as rapidly over the Provinces as the ocean itself might rush in if the vast barriers which protect the western shores of Holland were intersected or overthrown. Every place of defence had yielded almost without a day's delay. The forces of the Dutch were scattered and unequal even to a single battle. One attempt had already been made on the life of De Witt,-the consternation was universal. Nothing remained but the hope of

1 Mémoire sent by the Marquis de Louvois to the Prince de Conde, November I, 167 I. (Mignet, iii. 665.) 
preserving the religion and the name of Holland. Yet even these were threatened with annihilation. M. de Groot was deputed to sue for peace, and on what terms? He was authorised to offer the cession of the whole country of the generality, which separated the United Provinces from the Spanish Low-Countries, from the Meuse to the mouth of the Scheldt,-Maestricht, Venloo, Bois le Duc, Breda, Bergen-op-Zoom, Sluys, etc.,- - the surrender to victorious France of a broad position between the humiliated Republic of Holland and the isolated Provinces of Spain; and to this was added ten millions for the cost of the war. Such conditions amounted to a complete accomplishment of the policy of Richelieu, Mazarin, and Lionne; Spanish Flanders was by these terms enclave in the dominions of France. But Lionne was no more; M. de Pomponne advised Louis to accept the proposal, but he had not sufficient influence over the King; the deplorable ascendancy of Louvois prevailed, the conditions were rejected, and, in order to wreak a little more barbarous vengeance on the 'miserable fishermen,' whom he affected to despise, Louis lost sight, at the critical moment, of the great political object of the war. The counter proposal of France required far more extensive territorial ces- 
sions, the establishment of the Roman Catholic Church and of the commanderies of Malta in the Seven Provinces, and 24,000,000 livres for the expenses of the war, besides some further marks of humiliation and disgrace.

The consequence of these overwhelming pretensions was the resistance of a desperate nation of free men, and an internal revolution in the States, which raised William of Orange to the station of his glorious ancestors. It was thought, and not without reason, that the youthful Stadtholder of that princely house would have personal claims upon his relation the Elector of Brandenburg, on Spain, on the Empire, and above all on England, far stronger than the political influence of De $\mathrm{W}$ itt. British commissioners arrived to endeavour either to moderate the policy of Louis, or to corrupt his young and patriotic antagonist; but their interference was vain, bound as the English crown still was to be an accomplice in the war. The Prince of Orange was determined to resist to the last extremity. Alas! that in the midst of events which had called forth so heroical a resolution on the part of the people of the United Provinces, the annals of the Republic should be blotted by the indelible stain of the blood of its greatest citizens, shed by unbridled faction and 
popular ingratitude. So perished the De Witts, amidst the convulsions (as it seemed) of their perishing country. John de Witt may have erred in some of the grand decisions of his policy; but, if he succumbed to statesmen not greater but only less upright than himself, his fame rests upon the more solid basis of an unshaken and unyielding virtue. In the secret history of these times-we fear it may also be added, in the diplomatic history of modern Europe-the integrity of John de Witt shines with few rivals. If we look for his parallel in our own day, we may be reminded of the simplicity of his manners, the austerity of his principles, and the energy of his character by one of the greatest of contemporary statesmen : but M. Guizot was never called upon to exercise the undivided responsibility of the Grand-Pensioner of Holland, nor did he ever find himself face to face with dangers which threatened the annihilation of his country. In England perhaps his friend Temple offers the nearest approach to the character of De Witt, for he at least remained simple in his tastes at the Court of Charles II., and honest in the midst of his wayward and servile counsellors.

The reaction caused by the events of the war now rapidly defeated all the laborious and careful diplo- 
matic combinations which had preceded it. At the end of June, Louis might have accomplished his object and remained at peace with Europe; at the end of July a treaty of defence was already concluded between the Emperor and the Elector of Brandenburg. The imperial army was assembled on the frontiers of Bohemia, under the orders of Montecuculi, and in a few weeks the theatre of war was transferred from Holland to the Rhine; the adversaries of France were no longer the 'fishermen' of the United Provinces, but the Princes of the German empire. For another year Louis struggled to defer the general rupture, which it was impossible to avert, but in August 1673 a solemn treaty was signed at the Hague between the Emperor, the States, the King of Spain, and the injured Duke of Lorraine ; and M. de Gremonville, who had maintained his position to the last, was ordered to quit Vienna. It is not a little remarkable that this able minister, who for nine years had sustained the policy of Louis with every resource of a consummate diplomatist, and who had received substantial marks of the royal favour, should at this moment have altogether disappeared from the scene of politics. He has not even retained a place amongst the throng of names which crowd a biographical dictionary, and our efforts to trace his 
subsequent fate have been unavailing. It is conjectured that he retired to the Abbey of Lire in Normandy, worth some 20,000 livres a-year, which had been bestowed upon him by the King.

In England the House of Commons and the people were exasperated to the last degree against the Duke of York's marriage, the French alliance, and the Dutch war. In vain did Louis offer Charles I $00,000 l$. to prorogue Parliament, in vain did he devote so,oool. to the purchase of parliamentary support. Arlington had given way; Louis himself found it expedient to assent to what he could neither prevent nor avenge; he released Charles from his engagements with a specious assurance of his compassion, and on the I 9 th of February 1674 the peace with Holland was signed in London. Shortly afterwards, the conferences for the peace which had been opened at Cologne were broken off; war against France was declared by the Diet of the Empire; the French army, which had commenced hostilities by the easy conquest of the United Provinces, was within two years compelled to evacuate all its Dutch acquisitions and turn its whole strength, directed by the genius of Turenne, against the combined forces of the continent of Europe. The whole diplomatic structure which Lionne had raised with so much care and VOL. I. 
patience had crumbled to pieces. The neutral powers had become hostile, the friendly neutral. Louis stood in that isolated position in which he had before contrived to place his enemies. The military glories of his reign and the energy of his own character rose with these dangers; nor, even when the death of Turenne had exposed the territory of France itself to invasion, and diffused a general gloom over the realm, did the spirit of the King fail. Sweden remained faithful to him, and made a diversion in his favour. Charles II. had contracted another secret treaty with Louis, which he was obliged to copy with his own hand, since not even his most confidential advisers dared to put their names to it or to transcribe it. By this compact Charles bound himself to support the interests of France at the conferences for the peace which were already opened at Nymeguen. At one moment a secret negotiation was commenced between Marshal d'Estrades, one of the French plenipotentiaries at the congress, and Pesters, a confidential agent of the Prince of Orange, for a separate treaty between William and Louis, by which the former would have had Maestricht and the Duchy of Limburg assigned to him in independent sovereignty. This proposal, however, was soon broken off, for though William had shown that he 
was not disinclined to its conditions, he refused to abandon his allies, and he had a higher object in view.

For several years the Orange party had made its influence felt in the British Parliament; and, by the advice of Temple, William chose this time, at which the affairs of Charles were in a state of formidable embarrassment, to repeat his visit to London and to solicit the hand of the Princess Mary. Charles was favourable to the marriage, because he thought the popularity of William might counteract the hatred and jealousy of the nation against his brother. James was taken by surprise, and hurried into giving his consent without his approbation; while Louis professed that the first tidings he had received of the marriage were from the public rejoicings in London upon the announcement of it.

The duplicity and vacillations of Charles deprived him of all influence, and at Nymeguen the dignity of England was more fairly represented by the character of her envoy, Temple, than by the policy of her cabinet. In spite of all the obstacles which were to be surmounted, the systematic will of the French Court prevailed. Holland at length concluded her treaty of peace, and shortly afterwards the other belligerent parties acceded to the terms of 
Louis. To this epoch the four volumes of these papers which have been given to the world up to the present time extend.

We have passed more rapidly over the later pages of M. Mignet's work, because, although they are ornamented with some of the happiest and most elaborate sketches and commentaries of that accomplished editor, they chance to contain less of novelty in the original documents interspersed through them, than the volumes from which we have more largely borrowed. With the exception of the curious and hitherto unknown fact, that the Prince of Orange had at one moment contemplated a separate treaty with Louis, there is little to be said of the negotiations at Nymeguen which the papers of Temple or of Estrades have not recorded.

It is not, however, amidst the din of fights or the throng of armies that we care to watch the operations of those subtle powers by which, in the long run, the relations of states are determined and the foundations of empires established or undermined. The combinations of policy and the conquests of the pen are disturbed or paralysed by the more violent casualties of a campaign ; and the last place in which diplomatic ability of the highest kind can be exhibited is at one of those congresses towards the 
close of a war, when the exhaustion of one party and the arrogance of another subject all the contracting powers to conditions which justice and prudence may equally disapprove.

It is not, we repeat, in those scenes of eclat that the great statesman seeks or finds his chief or his highest occupation. His ability is as much to be estimated by the evils and dangers he has silently avoided, as by the triumphs he has visibly achieved. During his life he bears the great secret of his task about with him untold; even to posterity the truth is not always confided. The acts of such lives are not recorded in trophies or celebrated by popular applause; but the memorials of their power must be sought, like those paintings with which the Egyptians were wont to deck the halls of their gigantic tombs, in the silent archives of the dead.

We know nothing in history more remarkable than the oblivion from which the publication of these volumes has rescued the fame of such men as Lionne and Gremonville-another example, if another were needed, of the preferences of fortune for men of action over men of thought. Yet to neither class is wanting a fitting recompense. We have already expressed a high opinion of the industry and talents of Louis; but if he was endowed with a remarkable 
power of borrowing or extracting from his ablest servants whatever was most conducive to the glory of his reign, he was little able to supply the deficiencies of less powerful minds, or to resist the temptations of unthwarted prosperity. The earlier part of his reign was rendered conspicuous by the qualities of a great prince; the latter years were tarnished by the unrestrained foibles of a weak man.

In following the progress of the negotiations and events which took place between the Peace of the Pyrenees and the Treaty of Nymeguen, we have very faintly expressed the feeling of reprobation which must be roused by the secret annals of those twenty years. But it would be hypocrisy to deny that there is something in the very progress of human energy and ingenuity directed to a successful issue, that carries with it a degree of interest, if not of sympathy, which we should be ashamed to entertain for its real object; nor would it be just to condemn without extenuation the men, worthy of better things, who made themselves the willing and effectual instruments of such a policy as that of Louis. In their creed all moral duties were comprised in the one precept of unlimited service to the king; in his, all laws were subordinate, not only to his own notions of the royal dignity, but also to the interests and 
aggrandisement of France. We must rejoice that the free institutions of happier times have established a very different system of public morality, and that they are armed with power to summon the rulers of states to render an account of their foreign relations before the incorruptible tribunal of the general conscience of mankind; for even upon the countries in which such institutions are least known, the public opinion of Europe imposes a reluctant, an insincere, but a cogent recognition of the general principles of international justice. It may be, indeed, that in point of foresight, subtlety, and decision, the diplomatic abilities of the ministers of Louis XIV. have not been surpassed in our own or any other age; but we rise from the perusal of these volumes with at least the ennobling conviction, that the political labours of our time are animated by a nobler spirit and directed to a better end. 


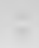

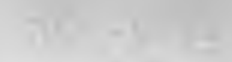

$1 \cdot$ 
SAINT-SIMON. 



\section{$S A I N T-S I M O N .^{1}$}

THESE recent editions of the two great literary monuments of the Court of France in its most splendid and memorable period are invaluable contributions to history and to letters. The 'Journal of the Marquis de Dangeau'-a minute and punctilious daily record of the monotonous grandeur of Versailles for forty-four counted years-is now for the first time made public in its integrity. The 'Memoirs of the Duke de Saint-Simon' have been carefully collated with the original manuscript by M. Chéruel, and we are indebted to him for the most correct text and the most acceptable form of

1 This paper was first published in the Edinburgh Review. No. 243, for January 1864 , as a review of the following works :-

1. Fournal du Marquis de Dangeau, publie en entier pour la première fois par MM. Soulié et Dussieux, avec les Additions inédites du Duc de Saint-Simon, publiées par M. Feuillet de Conches. Dixneuf tomes. Paris : 1854-1860. 2. Mémoires complets et authentiques du Duc de Saint-Simon sur le Siecle de Louis XIV et la Régence, collationnés avec le Manuscrit original par M. Chéruel, et précédés d'une Notice par M. Sainte-Beuve. Vingt tomes. Paris: 1856-1858. 3. Deux Discours sur le Duc de Saint-Simon, sa Vie et ses Écrits, qui ont remporté le prix d'Eloquence décerné par l'Académie française dans sa Séance publique du 30 août 1855. Par M. Eugène Poitou et par M. Amédée Lefèvre-Pontalis. 
this masterpiece of personal history. Indeed, this edition is so superior to all that have preceded it, that it will henceforth supersede them in every good library: though we think $M$. Chéruel might have extended his notes with further advantage. Criticism and annotation have still, as it were, to do their work upon this vast fabric; but that work has been ably commenced by the young and eloquent candidates whose essays were crowned by the French Academy in 1855 , and by M. Sainte-Beuve in his introduction to M. Chéruel's edition.

But the acquisition we have made in these important publications does not stop here. This edition of the Journal of Dangeau is enriched with the copious manuscript notes and additions of SaintSimon himself, now first published from the interleaved copy of the Journal which was made for his use by order of his friend the Duc de Luynes-the same copy which is still preserved in the Archives of the Foreign Department at Paris, where, indeed, all the Saint-Simon papers are now deposited. These manuscript notes, which are elaborate and voluminous, constitute a large addition to all that had previously been published under the name of Saint-Simon himself : they are anterior to his Memoirs in the shape he ultimately gave to them; 
they are, in fact, the materials of the Memoirs in a less complete form; but, at the same time, they contain numerous particulars, anecdotes, and characteristic touches which are not to be found in the Memoirs at all.

Moreover, the discovery of these 'Additions' throws an entirely novel light upon the manner in which Saint-Simon produced his great work, and on its connection with Dangeau's Journal ; although, indeed, as we shall presently show, light and darkness are not more opposite than these two noble authors, whose fame rests not on the splendour of their fortunes or their lives, but on the perseverance with which they recorded the events of their agehating and despising one another, although simultaneously engaged upon the same task-with no point of resemblance in tastes, in character, in purpose, or in style, yet inseparably united in the common result of their separate labours. Without Dangeau the Memoirs of Saint-Simon would perhaps never have existed in their complete form; without Saint-Simon the dry and frigid daily annals of Dangeau would never have been printed. Dangeau is the stock, incapable of producing palatable fruit itself, on which the most luxuriant and aromatic growth of French literature in that age was grafted. 
Dangeau, in his daily task of four and forty years, never rises beyond the level of the Court Circular : he witnesses the most important events of an eventful reign without an expression of wonder or emotion : even his anecdotes are without point : he is as exact and as unmeaning as a piece of clockwork. SaintSimon, on the contrary, painted in colours that will never die every figure and every scene, the bare mention of which suffices to his mechanical anti-type. In the slender entries of the one it is scarcely possible to trace more than a feeble pulsation of passions which might have touched the soul of even a master of the ceremonies; in the torrent of eloquence and of scorn poured forth by the other, Versailles lives again, with all its conflicts, its follies, its jealousies, and its power. Dangeau was a gilded insect, hovering over the Court parterre, or enthroned upon its blossoms; Saint-Simon was a mind, intent to try the Court by the touch and standard of honour, rectitude, and truth. The former shared the pleasures and the honours of Louis XIV. without limit: the latter cared little for his pleasures, and never possessed his confidence; but stood behind his throne and upon his tomb to be the avenger of his faults, even to the third and fourth generation. The easy and prosperous Marquis cared not to cast a 
look beyond the galleries of Versailles, in which he spent his existence; his conception of immortality was an apotheosis on a ceiling. How little could he have conceived it possible that he was day by day preparing materials for one who was to speak of all he adored in the language of doom - to consign himself and all his silken fellows to the pillory of history, and to herald by lurid and prophetic flashes the approach of that storm which the monarchy of France was not destined to survive! Dangeau, born in the King's own year, had seen the dawn and the meridian of a gay, splendid, and victorious reign, and his idolatry of the royal Sun of France was at least sincere. When Saint-Simon came to Court, thirtyseven years younger, the shadows were already lengthening; an age of cant had succeeded to an age of vice; the gloom of religious bigotry was followed by the shame of unsuccessful war and the horror of unnatural deaths: long before he completed his task the grave had closed upon Louis and the heavens themselves were gathering over France.

The fame, if so it can be called, which is attached to the name of the Marquis of Dangeau is dearly purchased. He owes his immortality to the pungency of the sarcasms of those who used his laborious compilations, as the most perishable 
commodities may be preserved by salt and nitre. For a man so easy, so good-natured, so incapable of independent action or of manly thoughts, to fall into the hands of Saint-Simon and Voltaire was, assuredly, a cruel sport of destiny over his grave. The birds of prey settled on it, and they have not respected his remains. But in spite of the strenuous efforts of the editors of this voluminous publication to rehabilitate his memory, to which they have done something more than justice, we must be permitted to retain our opinion that there was nothing dignified or respectable in his character except the perseverance with which he wrote his Diary. No doubt Saint-Simon and Voltaire were both of them largely indebted to so minute a chronicler of current events. No doubt it would have been more just and handsome to have acknowledged the obligation, instead of overwhelming him with ridicule and invective. But what was vindictive malice in Voltaire towards a man he had robbed, was the natural scorn of Saint-Simon towards a man he had known. Voltaire calls Dangeau a 'vieux valet de chambre imbécile, qui se mêlait de faire à tort et à travers des gazettes de toutes les sottises qu'il entendait dans les antichambres ;' and a 'frotteur de la maison qui se glissa derrière les laquais pour entendre ce qu'on dit à 
table.' Even when he refers to him as an authority he misstates and misquotes him. The truth is Voltaire had loosely perused the Journal in manuscript; and had found in it two or three not very flattering notices of himself. 'Le petit Arouet, poète fort satirique et fort imprudent, a été exilé. . . Arouet a été mis à la Bastille; il paraît incorrigible. . . Les comédiens jouèrent sur leur théâtre la nouvelle tragédie d'Edipe faite par Arouet, qui a changé de nom parce qu'on était fort prévenu contre lui, à cause qu'il a offensé beaucoup de gens dans ses vers : cependant la tragédie a fort bien réussi.' The Marquis little imagined that this same 'petit Arouet' would brand him for a blockhead for ever.

To measure the force and justice of these censures, it is necessary to retrace in a few sentences the chief incidents of Dangeau's inglorious life. Philippe de Courcillon, Marquis de Dangeau, neither deserved to be stigmatised as a man of slender birth by SaintSimon, nor exalted into a descendant of Hugues Capet by his own pen. The family of Courcillon was ancient, and the lordship of Dangeau was acquired by intermarriage with the Cholets in the fifteenth century. Some of its alliances were still more illustrious, for Dangeau himself was grandson of Anne de Mornay, daughter of Duplessis-Mornay, VOL. I. 
and in 1638 , the year of his birth, that descent marked in the nobility of France a Protestant house. Philip and his brother Louis, afterwards known as the Abbé de Courcillon, soon shook off, however, the Huguenot taint fatal to their career at Court ; and the elder brother served with sufficient brilliancy under Turenne to obtain in 1663 the command of a regiment of infantry, known as the King's Own, because it was especially created by Louis XIV. for the sons of noble families to serve in its ranks, and had till then been commanded by His Majesty in person. But it was not upon the fields of Flanders or of Spain that the laurels of Dangeau grew. $\mathrm{He}$ had learned in his campaigns the use of the Spanish language, which introduced him to the notice of the Queen, and he was gifted by nature with an extraordinary dexterity in all those games of skill or chance which were then the ruling passion of the Court: Dangeau himself had at that time little or no fortune; yet no one played so readily, or so high, or so well. In piquet, ombre, reversis, brelan, and all the games of the day, he was an acknowledged adept; in lansquenet and basset his judgment never failed him. Saint-Simon himself adds, 'this science brought him in a great deal, and his winnings enabled him to frequent the best society. $\mathrm{He}$ was gentle, com- 
plaisant, obsequious, with the air, the tone, and the manners of the world; prompt and accurate in his accounts at play, and however large his winnings may have been (and they were the basis of his fortunes), he was never suspected, and his reputation was always clear.' Indeed, he appears to have carried his theory of play to the height of algebraic calculation, and he employed Sauveur, the mathematician, to reduce the odds at basset to a precise formula. Madame de Sévigné described him in 1678 at the height of his glory presiding over the King's table at Versailles :-

Voici comme cela va-un jeu de reversis donne la forme et fixe tout. Le Roi est auprès de Madame de Montespan qui tient la carte; Monsieur, la Reine, et Madame de Soubise ; Dangeau et compagnie ; Langlée et compagnie ; mille louis sont répandus sur le tapis; il n'y a point d'autres jetons. Je voyois jouer Dangeau, et j'admirois combien nous sommes sots au jeu auprès de lui! Il ne songe qu'à son affaire, et gagne où les autres perdent; il ne néglige rien, il profite de tout; il n'est point distrait ; en un mot sa bonne conduite défie la fortune : aussi les cent mille francs en dix jours; les cent mille écus en un mois, tout cela se met sur le livre de la recette. Il dit que je prenois part à son jeu, de sorte que je fus assise très-agréablement et trèscommodement. Je saluai le Roi : il me rendit mon salut comme si j'avois été jeune et belle.

When Madame de Sévigné paints a scene, no touch is wanting to complete it. But to return to Dangeau. He was believed to have won a couple 
of millions of livres at play, without cheating; and with this fortune, and pleasing though somewhat pedantic manners, he advanced in life. An epigram of the day notched every round of his ladder.

Etre des plaisirs de son Roi

Du jeu, du bal, et de la chasse,

Faire exercice en bel arroy,

Monter quelquefois au Parnasse,

Donner tout à l'ambition,

Cajoler la blonde et la brune,

N'avoir point de religion

Quand il s'agit de sa fortune,

Devenir chef du régiment,

Acheter un gouvernement,

Se voir cordon bleu d'espérance,

Dangeau, par des hasards si grands,

Si la paix dure encor dix ans

Tu seras maréchal de France.

In the early years of Louis XIV., before bigotry and ennui had overshadowed the Court, Dangeau had enjoyed the unbounded confidence of the monarch-in his pleasures. They were born in the same year, and Dangeau was one of the few courtiers of the Grand Monarque destined to survive a reign of seventy-three years. In early youth he had been employed by Louis to write passionate madrigals to Mademoiselle de la Vallière, until it also occurred to Mademoiselle de la Vallière to apply to 
him to write her answers to the King, and the correspondence flourished the more as he held both ends of it. Some obscurity rests upon an expedition he made to England with M. de Briole, about the year 1676, for the purpose of fighting Lord Peterborough, of whom he had won four thousand pistoles; for it seems that, in order to prevent the duel, the heroes were arrested when they reached our shores. The wits of the Court laughed at his valour; but it was impossible to deny his readiness in rhyme. One day he entreated the King and Madame de Montespan to grant him rooms in Versailles; they told him he should have them if he filled up a hundred bouts-rimes before they had finished the game they were playing, and they did what they could to make the task impossible, but the Muses were favourable, and Dangeau had the rooms. This and similar exploits were indeed but a courtier's title to the honours of the French Academy, to which he was elected in $\mathbf{1 6 6 8}$, at a time when it certainly was not foreseen that he was destined to hold a permanent place among the historical writers of his country. The probability is that his enlightened patronage of Boileau and his encouragement of men of letters had given him some claim to their gratitude. Boileau had dedicated to him, in 1665 , the fifth satire, 'Sur 
la Noblesse ;' and before it was published Dangeau took the opportunity of reading the lines aloud in the King's hearing. Louis rose from the card-table to listen to it, and the fortune of the poet was made. Certain it is that without the slightest pretension to any literary graces of his own, Dangeau was a friend of literature, and literature is not ungrateful to him, since she preserves his name from oblivion. His brother, the Abbé, it may here be remarked, was also a member of the Academy, and perhaps with a better literary title. But the Abbé was a frightful bore-a greater bore than even his elder brother. He knew all the languages of modern Europe, and all the branches of modern science, and used to boast that he had two thousand verbs conjugated in his writing-desk. The following stanzas hit off the two brothers in an amusing manner :-

Avec mine pédante,

Le docte Abbé Dangeau

Au fils de Dieu présente

Son alphabet nouveau,

Lui dit 'Je t'apprendrai les étymologies,

Les termes du blason, don, don,

Et des Rois de Judah Les généalogies.'
' Cet ecclésiastique,'

'Répond son frère aîné,

' Est homme méthodique S'il en fut jamais né.

Pour moi, j'arais acquis quelque gloire au Parnasse,'

Puis d'un doucereux ton, don, don,

Ses vers il récita, la, la,

Et parla de sa race. 
The society of courts is so constituted (perhaps even in our own time) that one quality is more prized in them than the fairest virtues or the brightest talents ; a quality which may be described in English by a single word-deportment. The favoured attendants of kings are neutral beings, who dignify their menial condition by the satisfaction of a servile vanity. Of these Dangeau was a finished type; and he both had, and has, his reward. He might be, as Saint-Simon said of him, bedizened with absurdities; his inanity might turn one's stomach; but no one ever heard him say anything ill-timed or impertinent, for he was incapable of even that degree of mental independence. Madame de Montespan declared that it was impossible to help liking him, and laughing at him; but he was acknowledged, even by those who laughed at him most, to be an honourable and kindly gentleman. Whatever soul he had was absorbed in entire devotion to the King, even to the least and meanest appendages of majesty. The rise of his fortunes was therefore rapid. When the Duke de Richelieu, ruined at play, was compelled to sell his post of lord-in-waiting to the Dauphiness, Dangeau, who had probably won his money, bought it for a round sum, and this position afterwards made 
him one of the 'menins' 1 of the Dauphin. SaintSimon confounds the Marquis with his brother the Abbé when he says that the former personage also bought the charge of 'reader' to the King; he needed no such post about the royal person, for Louis XIV. bestowed upon him, as a special mark of favour, a formal warrant under the sign-manual, enabling him at all times whatsoever to enter the place where the King might be. He bought the Government of Touraine; he was made Grand Master of the Order of St. Lazarus, in which function he aped his master to the infinite diversion of the Court. By his first marriage, in 1682, he had greatly increased his fortune, and from his daughter. by that marriage, who afterwards became the wife of the eldest son of the Duc de Chevreuse, descends the present representative of Dangeau, the virtuous and accomplished Duc de Luynes-who is the possessor of his manuscripts. His second marriage was still more brilliant. A certain Countess von Lowestein, a German chanoinesse, descended from the Palatine House, and connected with the noblest families in the Empire, was one of the maids of honour of the Dauphiness. She had

1 This expression was introduced at the Court of France from that of Spain, where the 'meninos' were young persons of rank brought up with the princes. 
not a penny; but she was niece of Cardinal Fürstemberg, and a favourite of Madame de Maintenon; moreover of peerless beauty and unsullied reputation - jolie comme le jour, et faite comme une nymphe, avec toutes les grâces de l'esprit et du corps,' to quote the unsuspicious testimony of Saint-Simon to her merits. In 1696 Dangeau was fifty-eight years old, and Mademoiselle de Lowestein had sense enough to see through him-'elle vit le tuf,' says the censor; but the King favoured the marriage, the lady at last accepted him, and Dangeau fancied himself Elector Palatine, whatever else he gained by this marriage. It was delightful, adds his merciless adversary, to see him expand into mourning for his wife's relations.

About the same time he was made 'Conseiller d'Etat d'épée,' and soon afterwards his wife became a lady of the bedchamber.

All this puffed up Dangeau, and marvellously increased his absurdities. He adored the King and Madame de Maintenon; he adored the Ministers and the Government ; his adoration, perpetually displayed, had crept into the marrow of his bones. Their tastes, their affections, their aversions were altogether his. Everything the King did, whatever it might be, and sometimes however strange, transported Dangeau with admiration through and through. It was just the same for all that he saw Madame de Maintenon like, favour, or discard ; and this was so incrusted in him that it became himself even after their death. Hence the 
prepossession which all his timorous policy fails to conceal in his Memoirs against the Duke of Orleans, and in favour of the bastards in general, but especially of the person of the Duke of Maine. (Saint-Simon, tom. xviii. p. 60.)

These words may serve to put the reader on the track of the fierce contradiction and intense opposition which manifests itself in every line of these two records of the same period. The men differed not less in their political and personal predilections than in their characters and mode of life. What the one adored, the other hated and despised. The ruling passions which pervade the work of SaintSimon, and serve even to connect its different parts, are his detestation of the King's bastards, his aver-, sion to the lawyer element in the Parliaments of France, his personal attachment to the Duke of Orleans, his lofty conception of the functions of his order, his abhorrence of the high church party, and his hostility and resentment against the King himself. Dangeau, on the contrary, preferred Madame de Maintenon and the Duc du Maine to Fénelon and Beauvilliers: he was more inclined to side with pliant lawyers than with haughty peers: he feared and abhorred the sinister independence of the Palais Royal; and he would have been content to stake his hopes of another world on the favour of the 
King's confessor. In a word, Saint-Simon stood like a rock against every one of the influences paramount in the last twenty years of the reign of Louis XIV.: Dangeau floated with the stream. The one thought compliance base; the other thought resistance ridiculous.

Such was the man who is now brought prominently before the notice of posterity, although his merits and his faults, alike insipid and obscure, might fairly have consigned him to oblivion, but for the six and thirty folio volumes which it was his fate to leave behind him. Of the book itself we shall leave Saint-Simon to give his own account :-

From the commencement of his appearance at Court, that is about the time of the death of the Queen-mother, ${ }^{1}$ he took to writing every evening the gossip of the day, and he persevered in this task till his death [in 1 $^{20}$ ]. He persevered also in writing all this like a gazetteer, without a single remark, so that his Journal contains nothing but incidents with a correct date, but not a word of their causes, still less of any intrigues or movements whether of

1 Saint-Simon is mistaken. Anne of Austria died in 1666; Dangeau's Journal begins on April I, 1684. Dangeau himself was then forty-six years old, and had been about the Court more than twenty years, for he obtained the colonelcy of the King's Own regiment in 1663. It is possible, however, that he may have kept a diary long anterior to that which is now published. It may be as well to remark that in this and the following translations of passages in Saint-Simon in this article, we have sought as far as possible to preserve the roughness, and even the occasional incoherence of style of the author, sometimes, as in the original, at the expense of grammatical correctness. 
the Court or of private persons. The baseness of a humble courtier, adoration of the Master and of everything that was or smelt of favour, a profusion of insipid and contemptible adulation, a sufforcating and unceasing incense of the King's most indifferent actions, the dread which haunted him of even saying anything by which anybody might be wounded, excuses for everything, especially in the generals and other persons liked by the King, Madame de Maintenon, and the ministers ; all these things abound in all his pages, each of which generally suffices for a day, and they are marvellously disgusting.

It is difficult to conceive how a man could have the patience and the perseverance to write such a work every day for more than fifty years, so meagre, so dry, so constrained, so cautious, so literal - to write under the rind of the most repulsive aridity. But it must also be said that it would have been difficult for Dangeau to write real memoirs, which require a thorough knowledge of the interior and the diverse workings of a Court. Although he hardly ever left it, but for a moment, although he lived at it with distinction and in good society, although he was liked at it and even esteemed on the score of honour and discretion, it is nevertheless true that he never was in possession of a single thing, nor initiated into anything that happened. His frivolous and superficial life was like his Memoirs; he knew nothing more than everybody saw; he was content to be at the banquets and the balls, as his vanity takes care to proclaim, but he never was in any privacy. He may sometimes have been informed of things relating to his friends, by themselves, and as they were persons of consideration they might give him some relative intelligence, but this was neither long nor frequent. His friends of this class, few in number, knew too well the lightness of the stuff to lose their time upon it.

Dangeau had a mind below mediocrity, very futile, very incapable in all respects, easily taking the shadow for the substance, feeding on air and perfectly satisfied with that diet. His whole 
ability went no further than a studied behaviour, careful to wound nobody, and to multiply those puffs of wind which flattered him; to acquire, to preserve, and to enjoy a sort of consideration without caring to perceive that, from the King downwards, his vanities and his foibles were the laughing-stock of society, or the traps into which he was often made to fall. With all this, his Memoirs are full of facts not noticed in the gazettes; they will gain value as they grow old; they will be of great use to any one who seeks to write with more solidity, for an accurate chronology and to avoid confusion. Indeed they present, with the most desirable precision, the outward aspect of the Court, the day's life and what it consisted of, the occupations, the amusements, the division of the King's time, the chief occupations of everybody at it, so that nothing could be more desirable for history than to have similar memoirs of all the reigns, if it were possible, from Charles V., which would throw a marvellous light on the futility of all that has been written on these reigns.

A word more of this singular author. He made no secret of this Journal, because he wrote it so that he had nothing to fear from it ; but he did not show it; it has only been seen since his death. It has not yet been printed, and it is in the hands of the Duc de Luynes, his grandson, who has allowed some copies to be taken of it. (Saint-Simon, tom. xviii. p. 6o.)

If, on the one hand, Saint-Simon has described the style and the character of the author of the Diaries with his usual caustic felicity, it is impossible to acquit him of some want of candour in this reference to a work by which he himself largely benefited. Nobody would infer from this passage, and indeed the discovery has only been made very recently, that Saint-Simon alludes to himself in the 
sentence we have printed in italics. $\mathrm{He}$ it was who, undertaking to write the history of the period with greater solidity, condescended to borrow from Dangeau at least the chronological order of his narrative. But before we enter upon the proof of this curious species of plagiarism (if so it can be called), we must trace the history of the Journal itself.

The original manuscript is still at the Château de Dampierre, the seat of the Ducs de Luynes: it consists of thirty-seven folio volumes: the year I693 forming two volumes; almost every other year a single one. Dangeau devoted a separate page to each day in the year, and indeed rarely filled it. The margin of this manuscript bears numerous pencil-marks and references made by Saint-Simon, to whom it was lent by the Duc de Luynes his contemporary; and other marks by Madame de Genlis, who had it for ten years for the purpose of preparing an edition of very imperfect extracts from the text. Several other copies of the manuscript are in existence. Of these the most important was that made for Saint-Simon with alternate blank pages to enable him to interpolate his own notes and additions; and each volume of this copy contains a classified index under different heads of subjects-as 
Rangs, Mariages, Morts, \&c.-carefully prepared by Saint-Simon or by his secretaries. Some partial and incomplete publications of the Journal, or rather of extracts from it, had previously been made; the first by Voltaire in I 770; the second by Madame de Genlis, who began the work under the patronage of Napoleon, and ended it by a dedication to Louis XVIII.: it appeared in four volumes in 1817 . Lemontey published some further extracts in 1829 , and MM. Paul Lacroix and Amédée Pichot again in I830. But these fragments give no idea of the magnitude and importance of the work for historical reference-still less of the brilliancy and interest of Saint-Simon's Additions. We owe to the present editors a complete and careful revision and publication of the whole of these vast materials, which cannot fail to find a place in every historical library in Europe.

It results from the researches of the recent editors of the Dangeau Journal, and from a comparison of the text of Saint-Simon's Additions with his finished Memoir, that these notes (which are frequently of great extent) must be regarded as the basis of the Memoirs themselves. In fact, many of the most striking passages in the Memoirs-as for example, the magnificent character of the Duc de Bourgogne, 
and the affecting narrative of the death of the Duchesse de Bourgogne, followed immediately by that of her husband-were originally composed in the form of annotations to Dangeau. Thus even the character of Louis XIV. and of his reîgn, which is introduced in the Memoirs at the time of his death, fills a note to the Journal of the same date of no less than eighty pages octavo of small type. The same may be said of an immense number of characters and anecdotes. Yet the materials to be found in the 'Additions' were by no means all employed in the composition of the 'Memoirs ;' on the contrary, the earlier work is a store of fresh matter, frequently of the liveliest interest. In the passages which were transferred to the 'Memoirs' and incorporated in them, the style has undergone some revision and is somewhat more subdued than in the first burst of Saint-Simon's impetuous eloquence. It is also heightened in effect by numerous additional touches. The fact that the 'Memoirs' were written subsequently to the 'Additions,' is proved by innumerable circumstances, to some of which we shall presently have occasion to refer.

Dangeau himself died in September 1720 , and had written up his Journal till within three weeks of his death. His widow showed his manuscripts, and 
allowed copies to be made from them. Madame de Maintenon had had a copy at St. Cyr some time before, which she read with extreme entertainmentas well she might, for it was the reflection of her own existence. $^{1}$ But Saint-Simon expressly states that he never saw the Journal until after Dangeau's death; and there is evidence at Dampierre that it did not come into the possession of the Duc de Luynes, who had the copy made for Saint-Simon, until I 729. There is also internal evidence that the 'Additions' were chiefly written between the years 1734 and 1738 . Thus, in a note on the year 1705 , speaking of the R. P. François Marie, then General of the Carmelites, he adds that this reverend person 'died at the age of sixty-seven, in this year $\mathrm{s} 734$, with a great reputation.' In the survey of the King's reign, which occurs at the date of his death in I715, he states that Puységur was not made a marshal of France till $\mathrm{I} 735$. In speaking of Madame Guyon, who died in I 7 I 7, Saint-Simon says that 'although she has been dead twenty years, her little flock still exists, and still hopes to obtain the

1 Madame de Maintenon, writing in February 1716, soon after the King's death, says, 'Je voudrois savoir jusqu'où M. de Dangeau conduit ses Mémoires, afin de les ménager plus ou moins, car c'est le seul amusement que j'aie.' In fact at that time they were not completed, for Dangeau lived to carry them down four years later than the time at which she was then reading the earlier portion of them.

VOL. I. 
reversal of the decree which condemned their doctrines ;' this passage must then have been written in 1737 or later. So again in describing Lord Stanhope's visit to Paris in 1720 , Saint-Simon speaks of him as the predecessor of Walpole, 'dont la puissance dure encore'-these words were therefore written towards the latter part of Sir Robert's administration. It is clear that these notes were made nearly thirty years after the period to which they relate, that is, not before 1735. From the same kind of evidence the editors contend that Saint-Simon did not begin to give to his Memoirs their permanent form before the year I 740, and that they were entirely composed at La Ferté-Vidame, his country-seat, after that date; and it is certain that his own 'Introduction,' in which he discusses the propriety of writing contemporary history, bears date July 1743 . It should be observed that the manuscript of the Memoirs, which still exists in the possession of the present representative of the family, ${ }^{1}$ is entirely written by Saint-Simon himself,

1 We believe that this gentleman is called in France the Duc de Saint-Simon, and indeed sate under that title in the Senate of the Empire : but we are not aware that he has any right to it. $\mathrm{He}$ is really the Marquis de Saint-Simon, being descended from another branch of the family, in which the duché-pairie never passed at all. The Duc de Saint-Simon, the author of the Memoirs, had two sons, born in 1698 and 1699 respectively. The elder of these, known as the 
with great regularity and minuteness-a work of colossal magnitude, especially when it is considered that a large portion-perhaps the whole-had been composed and compiled in a more fragmentary shape, before it was fused down into its mature and perfect form.

The evidence here referred to as to the date of the composition of the Memoirs raises a variety of perplexing questions, and considerably modifies the opinion which has commonly prevailed as to the nature of Saint-Simon's work. From the extraordinary multiplicity of details it contains, which no human being could accurately retain in his memory for a lengthened period-from the intense vivacity and fever of the style, which burns with the passions of every hour, and is totally unlike the cool reminiscences of an elderly man writing twenty or thirty years after the events he describes-and, lastly, from Saint-Simon's own declarations, it has commonly been supposed that these celebrated Memoirs were for the most part written at the periods to which

Duc de Ruffec, died unmarried in 1746 ; the younger, known as the Marquis de Ruffec, married Mademoiselle d'Angervilliers, but had no children, and died in 1754-a year before his father, who thus survived all his offspring. The visionary author of the sect of Saint-Simonians was a Count de Saint-Simon, and a cadet of the family. 
they relate. The author himself says in his opening pages, that from his earliest years

The reading of history, and especially of the private memoirs of our own history since Francis I., which I carried on myself, gave me the desire to write those of what I might witness, desiring and hoping to be something myself, and to know as well as I could the transactions of my time. The objections to such a course were not unperceived by me, but the determination to keep the secret to myself alone appeared to me to remove them. I therefore began in July 1694, being then colonel of a regiment of cavalry bearing my name, at the camp of Guinsheim on the Rhine, in the army commanded by the Marshal Duke of Lorges. (Saint-Simon, tom. i. p. 3.)

If the Memoirs were originally composed in the solitary retirement of La Ferté many years after the occurrence of the events they relate, they would of course lose that highest claim to credibility which is due to contemporary records; and as regards the precise language used by Saint-Simon himself, and by other persons in many memorable interviews, it would deserve to be regarded as imaginary, if not fictitious. But the author of the Memoirs has guarded himself against this imputation in a very precise manner. He says in concluding his work :-

I have an observation to make as to the conversations I have held with many persons, especially with the Duc de Bourgogne, the Duc d'Orléans, the Duc de Beauvilliers, the Duc du Maine once, the late King three or four times, 'and with many other persons of note, and as to the opinions I may have given or 
rejected. These conversations are of such a nature, and so numerous, that I understand that a reader not acquainted with me might be tempted to rank them with those factitious harangues which historians have often lent of themselves to generals in the field, to ambassadors, senators, and conspirators, for the purpose of adorning their books. But I protest, with the same truth which has hitherto guided my pen, that there is not one of the speeches delivered or reported by me, which is not set forth in these Memoirs with the most scrupulous accuracy; and that if I have anything to reproach myself with, it is that I have weakened, rather than strengthened, my own language in this report of it, because the memory loses something of what took place, and in the vivacity of conversation one speaks with more force than one can give to the relation of what was said. I will add, with the same confidence, that no one who has known me, and lived with me, would conceive a doubt on the fidelity of these conversations or fail to recognise me in every line. (Saint-Simon, tom. xx. p. 93.)

It is certain that a report of a conversation having any claims to verbal accuracy must be made immediately after it took place; and from the care and evident pride with which Saint-Simon has preserved what he said, and what was said to him, on many momentous occasions, we cannot doubt that he made a careful note of it at the time. To suppose the contrary would be to destroy the chief value of the work.

But there is still more direct evidence that in I699, when the author was only twenty-four years of age, some portion of the Memoirs was already in 
existence. He had at that early period of his life conceived an especial veneration and regard for $\mathbf{M}$. de Rancé, the Abbé who had then recently retired to the monastery of La Trappe, which he was about to renovate by his ascetic piety. A singular counsellor for a young courtier on such a subject! Yet to the Abbé of La Trappe he addressed himself in the following letter-we shall quote the greater part of it, for it is extremely characteristic of the earnest and conscientious spirit in which Saint-Simon applied himself to this work, and it appears for the first time in M. Chéruel's edition :-

I must be well persuaded, sir, of your singular goodness towards me, to venture to take the liberty, as I now do, of sending you by the hands of $\mathrm{M}$. du Charmel the papers I had the honour to mention to you at my last journey, when you allowed me to do so. I then told you that for some time past I have been working on a sort of memoirs of my life, which contain everything relating especially to myself, and also, rather in general and superficially, a kind of narrative of the things of the Court ; and as I have proposed to myself the exact truth, and have therefore given myself free rein to speak it, good or bad, just as it seemed to myself about this person or the other, seeking to gratify my own inclinations and passions as far as truth allowed, since I am writing for myself, or for a very few of my own family during my life, and for whomsoever it may please after my death, I have stopped to spare no one on any consideration. But perceiving that this sort of work goes on every day increasing, and thinking with some complacency that I may leave it after me, but not wishing to be exposed to scruples which might induce me, towards the close of 
my life or even sooner, to burn it, as had been my first intention, by reason of all it contains against the reputation of thousands of people, and this the more irreparably as the whole truth is told, and passion has only inflamed the style-I have resolved to trouble you with some passages, to intreat you from these to judge of the piece, and to have the goodness to lay down some rule for me ever to speak the truth without wounding my conscience, and to give me wholesome counsel as to the manner I should follow in writing of things which touch myself more nearly than others. I have therefore chosen the narrative of our suit against MM. de Luxemburg, father and son, which gave rise to passages that roused in me almost all the liveliest passions, more sensibly than I had ever felt in my life, all which is expressed in a style that betrays it. This is, I think, the sharpest and bitterest thing in my Memoirs, yet I have endeavoured to adhere to the most exact truth. I have copied it from them, where it is recorded here and there, according to the time at which we pleaded, and I have put it all together ; and instead of speaking openly, as in my Memoirs themselves, I name myself in this copy as I name others, so that I may hereafter keep it and use it without appearing to be the author. I have also added two of my portraits as specimens of the rest ; that of M. d'Aguesseau, being favourable, may suffice for those of that sort, of which there are much fewer than of the bad. I flatter myself, then, that in the midst of your sufferings and troubles caused by this happy change in your great and wonderful monastery, you will have the charity to examine what I send you, to think of it before God, and to dictate the advice and salutary counsels I presume to ask of you, so that, being in writing, they may not escape my memory, and I may all my life have recourse to them. I think it superfluous to ask for precautions of secrecy, and as to the pitch of voice in which these papers may be read aloud to you, so that nothing be heard beyond your room; they themselves will sufficiently remind you of it. (Saint-Simon, tom. i. p. lx.) 
It is one of the strangest facts of this history that these tremendous revelations of the courts of kings and of the heart of man, which lay buried for nearly a century from the world, should have been whispered for the first time in a cell of La Trappe. That monastery was only five short leagues from La Ferté-Vidame, the country-house of the SaintSimons: M. de Rancé was a neighbour and friend of the first Duke; he was looked up to as a father by Saint-Simon himself; and in that stern abode the young Duke continued for long successive years to seek guidance and consolation, sometimes for weeks at a time. It was there he betook himself as a disappointed suitor of nineteen, when the daughter of M. de Beauvilliers declined to marry him; and he repeated his clandestine visits at frequent intervals-clandestine, only to avoid the remarks of the world on so rare a predilection in a young man of rank and fashion.

It is then evident from this letter that in the five years intervening between 1694 to 1699 , SaintSimon had already executed his design to a considerable extent, as far as his short experience then permitted. He knew what he had already written to be of a nature to affect the reputations of "thousands of people.' It may also be inferred that 
although his Memoirs were noted at the time in the first person, he afterwards, in recopying them, adopted the third person, and fused the separate passages of the narrative together. In the 'Additions' to Dangeau he always speaks of himself as the Duc de Saint-Simon; but in the final copy of the complete Memoirs he again uses the first person throughout, in speaking of himself. The passion for this species of composition grew with his years. His existence in Versailles-where he occupied the rooms on the upper floor of the palace, now partly adorned by the portraits of the Royal Family of England-was that of a recluse, as far as the exigencies of the Court allowed. He himself observes that, seeming to have nothing to do, he was constantly employed, chiefly in collecting and recording the occurrences of the time. We are informed that the mass of his manuscript notes, still in existence, many of which have not been examined, is enormous. Some of them were of a very delicate and compromising nature. The reader of the Memoirs will remember the terror of Saint-Simon, when the sudden death of the Duc de Bourgogne placed in the hands of the King a casket of confidential papers, which had been prepared for the young prince by his occult friend and adviser, and were only 
rescued from the grasp of Louis XIV. by the dexterous friendship of the Duc de Beauvilliers. These circumstances, to which many others might be added, convince us that to collect and prepare the materials of the Memoirs was the work of SaintSimon's life, and that he did not sit down at La Ferté at the age of sixty or sixty-five to recall the mere recollections of his more active years. The late Mr. Rogers was born in 1763 and died in 1855 ; his life, therefore, though twelve years longer than that of Saint-Simon, included the close of the last century and the first half of the present, just as that of Saint-Simon included the corresponding period a hundred years earlier. Saint-Simon writing from recollection the transactions he had witnessed thirty or forty years before, would have been in the same position as if Mr. Rogers had sat down in the reign of Queen Victoria minutely to describe in twenty octavo volumes the Court of George III., the frolics of the Princes, the 'delicate investigation,' and the death of the Princess Charlotte.

Pictures such as Saint-Simon loved to paint must be touched with moist colours. To take an ex ample, from amongst a hundred others. The four first days of the year I 7 Io were amongst the most remarkable of Saint-Simon's life : he remarks that 
'they deserve a sort of journal,' from the part he took in them, and from their ulterior consequences. He had just returned from La Ferté to Versailles, after an absence of several months. The manifest aversion of the King rendered the life of a courtier disagreeable and degrading to him. All hope of employment during the reign of Louis was at an end. At thirty-five he was disposed to break with the Court altogether, though as the King's reign was evidently approaching its close, and SaintSimon was in favour with his apparent successor, this resolution was less desperate than it looked at first sight. On his arrival at Versailles he found the disfavour and the disgrace of the Duke of Orleans more complete than his own, and with this aggravation-that the Prince deserved it. His scandalous liaison with Madame d'Argenton, and the orgies of St. Cloud, had excited against the Duke the irritation of the King (who resented the affront to his daughter), the disgust of Madame de Maintenon, and even the cry of the French Court. Saint-Simon instantly made up his mind that if he was to remain at Versailles at all-if he was to save the Prince who was his friend from utter ruin, and to regain any position in the King's favourit could only be by heroic measures and a signal 
victory. On this determination he acted. On January I, he told the Duke of Orleans that there was but one remedy for the evil-that he must renounce Madame d'Argenton, to whom he was extravagantly attached. For three days, supported by a single friend, Marshal Besons, Saint-Simon renewed the assault. He poured forth a torrent of expostulation, of ingenious argument, of menace; on the third day, by the sheer force of energy and of eloquence, he triumphed : to the astonishment of the Court and of the town it was announced on January 4 that Madame d'Argenton was dismissed. The spell was broken-the victim of vice and passion was delivered. That same morning SaintSimon, himself still in disgrace, had an audience of the King, and without any reference to the service he had just rendered to the Royal Family, he succeeded, by a temperate assertion of his own loyalty and self-respect, in softening to some extent the pride and the prejudices of the proudest and most jealous sovereign who ever reigned. All these conversations are related in the Memoirs with verbal and literal accuracy. Even the positions and attitudes of the respective personages are portrayed. No detail is omitted which can give life and reality to the scene. To believe that these chapters were 
written thirty years after the event is to attribute to. Saint-Simon either a miracle of memory or a mere romance. We infer, on the contrary, from this and similar passages, that it was his habit to reduce to writing in the form of a journal conversations and incidents of great interest relating to himself, and that these passages were afterwards incorporated in his great work.

The fragmentary character of these materials or passages, written, as Saint-Simon himself declares, under the passionate influences of the moment, may be traced throughout; and this theory explains the occasional intervention of long and even tedious episodes and dissertations, which were woven into the Memoirs, sometimes without much reference to the context. But where the chronological thread of the narrative is well preserved in relation to public events or to third parties, it is mainly due to the use Saint-Simon made of Dangeau's Journal.

The first ten chapters of the Memoirs are remarkably incoherent, as if the author had not yet settled the plan he was finally to adopt. After succinctly relating the incidents of his own birth and boyhood, with his entry into the Grey Musketeers, Saint-Simon suddenly breaks, in his second and third chapters, upon the memorable scene of the 
marriage of the Duc de Chartres (afterwards the Regent Orleans) with Mademoiselle de Blois, the second of Madame de Montespan's daughters; and the marriage of the Duc du Maine, another of the King's bastards, to a daughter of the House of Condé. It was on that occasion that Madame, indignant with her son for consenting to such an alliance, boxed his ears when he approached to kiss her hand in the full assembly of the Court. ${ }^{1}$ But Saint-Simon (who as a boy of seventeen witnessed the scene) had another, and, so to speak, a more epic reason for relating it. The results of those ill-fated marriages-the never-ending struggle between the pretensions of the bastards of the King, whom it was his policy to intermarry with the junior branches of the Royal Family; and, above all, the personal hatred and rivalry of Maine and Orleans, which exploded twenty years afterwards on the King's death-are the rufos of the book. These sources of an almost Theban hatred are inexhaustible. They mark the course of events. They

1 The Memoirs have it, 'En ce moment Madame lui applique un soufflet si sonore qu'il fut entendu de quelques pas,' \&c. In the ruder language of his 'Additions' to Dangeau (vol. iv. p. 8) SaintSimon wrote, 'Mais au moment de lui prendre la main, elle lui décocha un soufflet à lui faire voir les chandelles.' These variations of style pervade the whole work, but the first expression of the passage is frequently the more vigorous of the two. 
mark still more the abhorrence of Saint-Simon for the illegitimate pretender and his indulgent affection for the Prince, who, with all his faults and vices, was at least not faithless to his early friend. Hence, in bringing the Duc de Chartres and the Duc du Maine thus abruptly on the scene in his second chapter, he at once rivets the attention of the reader on his principal personages. If this was an artifice of composition-and as such we regard it, for indeed the date of the marriage (1692) was anterior to the proper commencement of the Memoirs-it bears the stamp of maturity, and the passage was no doubt placed where it stands long after all the dire consequences of those ominous nuptials had unfolded themseives at the Court of France.

The death of his father, which occurred in 1693 , at eighty-seven years of age, raised Saint-Simon to the highest rank in the peerage: he was then himself about eighteen; for it may here be noted that Claude de Rouvroy, the first duke, was born in I606 under Henry IV., and his son, the subject of these remarks, lived till $\mathrm{I} 755$, the two generations extending for very nearly a century and a half-a period as long, in our own history, as that from the reign of James I. to the reign of George III. The young duke, who was the King's godson, entered 
upon his father's offices and dignities, and displayed at once a maturity of character capable of holding them. Hence, he relates with complacency the contest for precedency in which he was engaged with the Luxemburgs (the Duc de Luxemburg having claimed precedence over sixteen other peers); and, as we have seen, he selected this specimen of his Notes for the judgment of the Abbe de Rancé. The specimen we should now say was ill-chosen, for to modern eyes the subject is uninteresting and the style cumbrous. But such as it is, it fills the greater part of four or five chapters.

A considerable portion of the year 1695 was spent by Saint-Simon with the army on the Rhine, and it is not till the commencement of the following year that the series of events becomes regular; and here we find him at once on the track of Dangeau. The following passage, though not of especial importance in itself, will serve to show with convenient brevity how the Memoirs were constructed upon this basis.

Dangeau relates, with his accustomed formality, that-

On Sunday, rst January I696, at Versailles, the King convoked the Chapter of the Knights of the Order before going to chapel, and announced his intention to confer the honour of knighthood on the Duc de Lanti, a Roman, who had long borne the arms of 
France, his wife being of the house of Tremoille-Noirmoutier, sister of the Duchesse de Bracciano. After the Chapter we marched to the chapel ; the King took his seat and received the oath of the Bishop of Noyon, who has the place of the Archbishop of Paris. His Majesty then heard mass, and afterwards received the oath of the Comte de Guiscard, who was presented by the Marshal de Joyeuse and M. d'Aubigny. The cardinals at this ceremony had no stools, but sate on a bench like the other knights. The Cardinals d'Estrées and Fürstemberg were there. (Dangeau, tom. v. p. 340.)

Flat and uninteresting enough ! Yet of Dangeau's thirty-seven folios this is not an unfair specimen. Now let us see how Saint-Simon lights up the horizon. At the name of Duc Lanti, he first writes a note, which is to be found in the 'Additions,' in the following terms :-

Ce Duc Lanti est peu de chose. He took the name of La Rovere, because he had a mother who bore it, but those La Roveres were themselves peasants of Savona. It was a fisherman of that town or the environs who was father of Francis la Rovere who became pope in $147 \mathrm{r}$, and reigned for fourteen years under the name of Sixtus IV. That maniac Julius II., elected in 1503 , and pope for ten years, was the son of Sixtus' brother. They raised their family, into which fell the Duchy of Urbino and other great fiefs, by money and by great alliances which have reverted to the popes for the most part by usurpation. Cardinal d'Estrées got the Order for the Duc Lanti on account of the Duchesse de Bracciano, his sister-in-law, who was then very intimate with him, but who, becoming famous afterwards under the name of the Princesse des Ursins, quarrelled bitterly with him and his in Spain, \&c. (Additions to Dangeau, vol. v. p. 340.)

We now turn to the Memoirs themselves, where VOL. I. 
we find the same minute incidents and historical notes thus transformed :-

The year 1696 began by a little mortification to persons who were not used to such things. The King gave the Order to M. de Noyon and to Guiscard, and at the ceremony the Cardinals d'Estrées and de Fürstemberg had only a bench like the other knights. Little by little these dignitaries, skilled in usurpation, and happy to turn it into right, had found means to get stools placed at the credence of the altar, as the Princes and the Royal Family have near the King, who at last thought it amiss and took them away. They swallowed it without a word.

At the Chapter before the ceremony the King named the Duc Lanti of the Order, whose wife was the sister of the Duchesse de Bracciano, ${ }^{1}$ and who served him well, herself and her friends. These Lantis are nothing at all. They have taken the name Della Rovere, because they had a mother who bore it, and these Roveres were themselves of the dregs of the people before their pontificate. Francis della Rovere, who was pope in $148 \mathrm{I},{ }^{2}$ and reigned fourteen years under the name of Sixtus IV., was son of a fisherman in the neighbourhood of Savona, and that maniac Julius II., pope in 1503 , and for ten years, was the son of his brother. They neglected nothing to raise their family by money, by alliances, by seditions, and by any other means. The Duchy of Urbino and other great fiefs fell to them, which for the most part have since reverted to the popes.' (Saint-Simon, Memoirs, vol. i. p. 300.)

\section{It would be tedious to pursue this species of com-}

1 M. Chéruel's edition has it, 'dont la saur était femme de la Duchesse de Bracciano,' but this is evidently a șlip of the press : it should be 'dont la femme était saur de la Duchesse de Bracciano;' the Addition previously quoted called her rightly 'sa belle sœur.' The passage is correctly printed in the earlier editions.

2 The date was 1471, rightly given in the Additions, wrongly copied by Saint-Simon here. 
parison any further ; but every page of these vast. collections might furnish similar examples. Dangeau supplies the simple fact, succinctly stated, with chronological accuracy; and we believe that Saint-Simon seldom names a person or relates an occurrence (except those personal to himself) which do not occur in Dangeau's Diaries; but he immediately amplifies the event. He breathes life into these dead figures. Dangeau tells us that the Cardinals sate on a bench, and not on stools. What matter? Saint-Simon barbs the trivial incident with the sting of a mortification inflicted by the King on these arrogant priests. Dangeau names Lanti as a Roman nobleman, who had borne the arms of France. Saint-Simon connects him in an instant with a pontifical family, vituperates a brace of Popes, and has a side fling at the future Princesse des Ursins.

It may deserve to be noted that the Memoirs of Saint-Simon are not the memoirs of his life, nor did he ever intend that they should embrace the whole of that protracted period. They commence in 1695 with his entry into active life; they end in 1723 with the death of the Regent. The whole extent of them is therefore confined to twenty-eight years, although Saint-Simon lived thirty-two years after the event at which he brought them to a close. $\mathrm{He}$ 
was himself forty-eight years old at that date, and the rest of his life was.spent in comparative retirement-in fact, but little is known of his later personal history. There is, however, a passage, now first published, at the termination of the series, which intimates that he proposed in some measure to continue it :-

It is provoking (he remarks) to lose sight of the principal personages whom one has been reading of, while one's curiosity is unsatisfied. That is what I wish to prevent if God gives me time. Not indeed so exactly as when I was in everything. Though Cardinal Fleury concealed from me nothing that I wished to know of foreign affairs, and also of some transactions of the Court, I took so little part and interest in them that I have reason to fear this supplement to my Memoirs may be very languid, imperfect, and different from what I have hitherto written, but at least it will appear what became of the personages who have figured in the Memoirs, and this is all I propose to do, down to the death of Cardinal Fleury. (Saint-Simon, vol. xx. p. 93.)

It is even now by no means certain that this design was not partly executed, for the miscellaneous papers of Saint-Simon, preserved in the Archives of the French Foreign Office, have never been thoroughly examined.

But although the Memoirs themselves are restricted to this comparatively limited period, yet they constantly awaken in Saint-Simon's inexhaustible memory traditions and reminiscences extending a century further back, and descending to the very 
time when he committed them to paper. Thus, in the narrative of the intrigue, in I 700, to enable the Abbé de Soubise to be received into the highly aristocratic Chapter of Strasbourg, in spite of a notable blemish in his escutcheon, Saint-Simon runs up with fatal precision to the great-grandmother of the reverend candidate, who was the daughter 'de ce cuisinier, auparavant marmiton, après portemanteau d'Henri IV, qui à force d'esprit, d'adresse, de le bien servir dans ses plaisirs, le servit dans ses affaires, devint M. de la Varenne, et fut compté le reste de ce règne.' Cardinal Fürstemberg, the uncle of Mme. de Dangeau, was mixed up in this affair, and, accordingly, Saint-Simon takes the opportunity to retrace the history of his family from I635 down to I739. This is one of the passages which demonstrate that the Memoirs must for the most part have been written after the later date.

A still more striking example occurs at the fifth chapter of the ninth volume of the present edition (anno I7II), where Saint-Simon relates the commencement of the Constitution Unigenitus,-

... so fatal to the Church and the State, so shameful to Rome, so mischievous to religion, so advantageons to the priests, the Sulpicians, the ultramontanes, the ignorant, the creatures of nothing, and especially to all sorts of knaves and scoundrels-the consequences of which, directed as much as possible, on the 
pattern of the Revocation of the Edict of Nantes, have thrown everything into disorder, ignorance, deceit, and confusion, with a violence which still lasts, under which the whole kingdom groans and trembles, and which, after more than thirty years of effrenate persecution, lays on all things and on all professions a weight ever more extensive and more insupportable: To understand what I have to say of an affair which so principally occupied all the rest of the reign of Louis XIV., the minority of Louis $X V$., and all the reign, latent under the Duke (of Orleans), open since his fall, of Cardinal Fleury, many things which are scattered in these Memoirs must be recalled to mind. (Saint-Simon, vol. ix. p. 84.)

It is evident that this passage was written thirty years after the event to which it relates, and towards the middle of the eighteenth century; yet there is no reason to suppose that this or any similar passages have been intercalated in the manuscript. The same subject is briefly touched upon in one of the 'Additions' to Dangeau (March I, I 7 I I), in a note afterwards worked up by Saint-Simon into the passage we have just quoted.

In the general Introduction to the Memoirs which now stands prefixed to them, and which bears the date of June I743, when Saint-Simon was sixtyeight years of age, he expressly states that 'to write the history of one's country and one's time, is to go over in the mind with much reflection all one has seen, touched, or known upon the stage of the world, and the diverse mechanism, often of very slight 
account, which has set in motion the springs of events of infinite consequence.' That was precisely the task Saint-Simon proposed to himself and accomplished. The work he has left us may not always be a work of contemporary history, but it bears the stamp of his full and mature judgment on the events of his early and middle life, as well as of notes made at the time.

When Saint-Simon relates events which cannot have fallen within his own knowledge, his testimony is, of course, infinitely less valuable, by all the rules of historical evidence, even though he generally quotes his authority. Of this sort of mistake his narrative of the death of Henrietta of England, Duchess of Orleans, and sister of Charles II., is a memorable example. Everybody knows that, within a few days of her return from Dover, in June 1670 , where she had just negotiated a treaty between the two Crowns, this Princess suddenly fell ill, and died in ten hours. It was supposed she might have been poisoned in a glass of succory water: she herself thought so, and used some ominous words on her death-bed to Lord Montagu to that effect. SaintSimon takes an opportunity, upon the death of her husband in I 7OI, to revert to this occurrence, which had taken place more than thirty years before, and five years before his own birth; and he says that 
' no one doubted that Madame had been poisoned, et même grossièrement.' He then proceeds to relate the motive of this crime, and the means by which it was committed by D'Effiat, Beuvron, and Brissac, friends of the Chevalier de Lorraine, and servants of the Duke, though acting without his direct knowledge. The story, as given by Saint-Simon, was related to him by M. Joly de Fleury, a magistrate; and that person had it from Brissac himself (SaintSimon, tom. iii. p. I80.). Be this as it may, there is not a word of truth in it. Poison was no doubt suspected, both in England and France; but the despatch of M. de Lionne to M. Colbert, the French Ambassador in London, on July I, I670, ${ }^{1}$ demonstrates beyond all doubt that the Princess died from natural causes. The same statement is confirmed by Guy Patin, an unexceptionable medical witness. Her body was opened in the presence of both French and English surgeons, and of a hundred persons ; no indications whatever of poison were found. At the time when Saint-Simon asserted, apparently on the authority of others, that no one doubted the fact of the crime, several persons must have been alive who had positive evidence to the contrary.

We have then no doubt that the Memoirs were written in their definitive form in the last twenty-five

${ }^{2}$ Published in M. Mignet's Succession a'Espagne, vol. iii. p. 209. 
years of Saint-Simon's life, after he had retired to La Ferté; and from the uniformity of the manuscript still in existence, it is impossible to doubt that the author did, with his own hand, perform the enormous task of revising and re-copying all he previously composed and collected, with such additions and variations as events subsequent to the time he was describing enabled him to make. It is also proved that, in the main, he used the Diaries of Dangeau as - the basis of his narrative, from the names of persons, dates, and other incidents, arranged by himself in his indexes to that elaborate record. Yet we infer from the evidence already adduced that very considerable portions of the Memoirs existed in the form of notes, written at the time when the events to which they relate occurred, and that these materials were eventually melted down by the author into the form in which he has left them to us. We have positive proof that this was the case with those fragments which are now published as the 'Additions' to Dangeau ; and although this laborious mode of composition would seem ill-fitted to Saint-Simon's impulsive style and genius, we are compelled to adopt the conclusion that it was the mode he pursued.

We have entered at some length into these details, because they were not accessible until the 
recent publication of Dangeau's Journal, with SaintSimon's Additions, and are therefore new even to the most assiduous readers of the Memoirs themselves. But before we take leave of the subject, we desire to place on record our estimate of the character of Saint-Simon himself; and to this purpose some pages shall now be devoted.

We desire it the more because, although much French criticism has recently been applied to SaintSimon and his writings-although the French Academy has bestowed a prize on the remarkable Essays which we have quoted at the head of this paper-it appears to us that there is in France a disposition to underrate the true worth of SaintSimon, and in some respects an inability to understand him. To such men as the recent editors of Dangeau, who write as if they were under the influence of personal resentment, the sarcastic eloquence of this great noble seems to proceed from the meanest passions of envy and malice: his scorn and vengeance on the $\mathrm{King}$ is the result of disappointed ambition; his passionate defence of all the privileges of his order is a puerile vanity attempting to dignify its most frivolous distinctions. The French of the present day look on Saint-Simon with mingled and inconsistent feelings. They are com- 
pelled to admit that the prodigious force and variety of his style raise him to the very highest rank in literature-as keen a wit as Molière, as fervent a Christian as Bossuet, as stern in his judgments as Tacitus, as fierce in his invectives as Juvenal. But these great powers were too often exercised at the expense of men and things dear to the national pride of France. He stripped the trappings from that idol of Versailles, who was adored by the Court and the nation during his lifetime, and after a brief interval was again canonised even by Voltaire as one of the glories of France: even at this hour, Frenchmen cannot bear to speak too lightly of Louis le Grand. Saint-Simon drew him as he lived. Selfish, narrow-minded, ignorant; jealous to excess of his own authority, yet played upon by priests and by women; alternately swayed by passions and by prejudices, but successfully masking the infirmities of his character under that majestic deportment which seemed to the slaves about him to partake of divinity. It was of Vendôme that Saint-Simon said, 'Il connaît et abusa plus que personne de la bassesse des Français ;' but that taunt at the weaker side of the national character rankles still; and it might be said, even under Napoleon III., that the same readiness to bow the knee before the pretensions of 
factitious greatness has survived a couple of centuries, nor is any race of men less able to stand erect against the encroachments of power. These and similar reasons tend to render Saint-Simon not popular in France; his principles are out of date; and it may even be said that a knowledge of the past history of society in that country is becoming more rare, as with each succeeding generation the manners of the nation become more entirely dissimilar to the manners of their forefathers. Even before Saint-Simon had himself disappeared from the scene, he complained of the gross ignorance of his younger contemporaries, who did not so much as know how the Kings of France and Spain were related, or who was the father of the Regent Orleans! This 'abyss of darkness,' as he called it, has certainly not been dissipated in the succeeding century.

Saint-Simon was the last champion of aristocratic institutions in France; but it must be acknowledged that he contended for what had already ceased to exist. Aristocracy had already in his day collapsed into rank; and in place of the nobles who fought with Henry IV., who perished under Richelieu, and struggled against Mazarin, Saint-Simon found himself one of a flock of courtiers whose highest am- 
bition was to light the King to his bed-room or to hold his shirt while he was dressing. Yet he believed that, in presence of an absolute monarchical power, such as had arisen in France on the ruins of every other institution, nothing but an order of nobles, sufficiently protected by their privileges to be independent, could withstand the pernicious influence of the Crown. France has, since the Revolution, certainly lost the sense of what a class of great hereditary nobles may do for the cause of freedom. She has ceased to comprehend that, in contending against the Crown for their own privileges, they have, on a hundred occasions, covered and saved the privileges of the people. But at the time of which he wrote, the political principles of SaintSimon may not untruly be compared to those of the Whig Peers of England in I688. Saint-Simon may have been guilty of an anachronism; but Englishmen, at least, who owe so much of their liberties to the spirit and independence of the great Whig families of the last century, have no reason to convict him of absurdity.

Unhappily, his efforts were chiefly directed to puerile or sterile objects ; and, in fact, in contending for the dignity of his Order, he greatly overrated its importance. In his day, the old territorial peerage of 
France had ceased to exist. The Duc d'Uzès, then the oldest peer of the realm, owed his rank to Catherine de' Medici in 1572 , scarcely a century before Saint-Simon's birth. His own father, Claude de Saint-Simon, had earned the royal favour and eventually his peerage by no higher service than that of holding the King's second horse in the chase in such a manner that Louis XIII. could change his seat without dismounting. Such peers were the breath of a king's nostrils_all enriched by the Crown, all dependent on its pleasure : to raise such men to the rank of a House of Lords, holding a great position in the state, was an idle, though a noble, dream. Perhaps, however, even now we are led by the influence of subsequent events to underrate the true value of the French nobility in the eighteenth century. An ingenious writer, M. de Lavergne, has recently shown, by a careful investigation of the history of those Provincial Assemblies, which met just before the great convulsion of 1789 , that in almost every part of France there were men of character, talent, and patriotism equal to their rank, qualified to take a part in public affairs; and undoubtedly the first National Assembly in France contained an extraordinary array of men of great ability, far superior in everything but the sad experience of 
democratic revolutions, to any Assembly which could now be convoked or returned in the same country. That which was most needed to restore the nobility of France to its proper position, and to enlist it in the cause of constitutional government, was freedom of debate and independence of position. In our judgment, the incapacity of France to preserve institutions favourable to liberty, arises chiefly from the absence of a class of men powerful enough to resist the insolence of the Crown and wise enough to resist the extravagance of the people. To that class of men Saint-Simon would have belonged.

But the Duc de Saint-Simon, although his own life was prolonged until within thirty-four years of the French Revolution, belonged in character and principles to an age anterior to that of Louis XIV. He differed as essentially from his own contemporaries of the later years of that monarch, as the men who sate in the Long Parliament differed from the parasites of Charles II., or the plotters of the reign of Queen Anne. His nature was cast in a larger mould, and something of an heroic character mingled in all his thoughts : to use his own words, applied to his father, in him ' un reste de seigneurie palpitait encore.' His very language and style retain the archaic vigour of the earlier half of the 
seventeenth century, before boldness and originality of expression had been sacrificed to polish and precision. The profound reverence he never ceased to entertain for his parents extended itself to the objects of their affection and gratitude : to the close of his life he wore on his finger a miniature of Louis XIII. set in diamonds; in the chapel at La Ferté a lamp never ceased to burn before the bust of that prince; and he solemnly observed the day of his death as an anniversary of grief, a hundred years after that event had taken place. Nurtured in these serious traditions, he appears never to have been a youth. His earliest pleasures were innocent, his earliest tastes were refined, and this in a dissolute age, when all the splendour of the Court did not eradicate the coarseness of sensuality-when the Princesses of the Blood had been known to borrow the pipes of the guard at their door to smoke tobacco, and the younger branches of the royal family were not unfrequently carried drunk to their beds. These amusements had no charm for $M$. de Saint-Simon. We have seen how he succeeded at eighteen to the honours of his family, and how he placed himself under the direction of the severest of monitors, the Abbé de Rancé of La Trappe. He then immediately sought to connect 
himself in marriage with the family of the Duc de Beauvilliers, as much from sympathy for the virtues of the father as from admiration of his child. But this young lady preferred to take the veil; and Saint-Simon married a daughter of the Maréchal de Lorges, not less remarkable for the same austere qualities. 'She it was whom I preferred,' says he with exquisite simplicity, 'beyond all comparison, and with her I hoped to gain the happiness of my life, which it has solely and entirely been. As she became my wife, I shall abstain from saying more of her than that she has been to me infinitely more than had been promised me by others or than I dared hope myself.' His domestic happiness was complete. In all the great emergencies of life Madame de Saint-Simon appears as his best counsellor and friend, and their union was constant and unbroken.

Amongst other sarcasms flung at Saint-Simon, it is still the fashion in France to say he was a Jansenist ; and the term has not quite lost even now a sting of reproach. To the peculiar doctrines of that sect he was indifferent-he professed to be 'ni docte ni docteur'-and no one would have been less disposed to argue on the gifts of the Spirit or the mysteries of prevenient grace. But, with no taste whatever for vOL. I. 
the subtleties of theological controversy, SaintSimon was irresistibly drawn, by the purity of their lives and the Christian dignity of their characters, towards the men who professed strict opinions. He seems but once in his life to have had any direct intercourse with Fénelon, yet the portrait he has left us of that admirable being is of transcendent beauty; and he watched with the rapture of hope the influence the Archbishop of Cambrai had acquired over the Duc de Bourgogne-that young Marcellus who was to restore the monarchy to order, rectitude, and truth. So too he admired the simple dignity of the character of Vauban, and he lived as a son under the tutelary care of $\mathrm{M}$. de Beauvilliers and M. de Chevreuse. Nor was this all. His affection for men suspected of Jansenist opinions was equalled by his hatred of their opponents. $\mathrm{He}$ detested that knot of Jesuits who, through Madame de Maintenon, had thrown their baleful influence over the kingdom. He resisted and denounced that constitution of the clergy by the Bull Unigenitus, which was the triumph of their art; he abhorred that desecration of the sacred shades of Port Royal, which was the triumph of their intolerance. No man can read these Memoirs without being struck by the unaffected piety of their author; no man can 
read them without feeling how widely the religion of Saint-Simon differed from the religion of the Court. The following passage, among a hundred others, may be taken to convey his judgment on these questions :-

The quarrel (of the Jansenists) grew keener and more onerous to the Jesuits. Father Letellier took in it a double part. $\mathrm{He}$ was, as I have said before, a fervent man, whose God was his Molinism and the authority of his Company. He held good cards : a king, very ignorant of these things, who had never listened to anyone but the Jesuits and their fellows, supremely; full of his own authority, and persuaded that the Jansenists were hostile to it-anxious to be saved, but knowing nothing of religion, flattering himself that he might do penance on the backs of other men, especially on such men as the Huguenots and Jansenists, whom he supposed to be about the same thing and alike heretical; a king surrounded by people as ignorant and prejudiced as himself, or by courtiers or head valets who knew no more about it, or who thought only of their own fortunes; a clergy which had long been destroyed, and of late especially by the Bishop of Chartres, who had stuffed the episcopate with ignorant, unknown, low-bred fellows, who thought the Pope a divinity, and held in abhorrence the maxims of the Church of France, because all antiquity was alien to them, and being creatures of a low origin themselves, they did not so much as know what the State was; a Parliament emasculated and tremulous, long accustomed to servitude, and even those in it who might have spoken obsequious as the first President Pelletier, or greedy of favours. (Saint-Simon, tom. vii. p. $4 \mathrm{I} 6$.)

Such were the means by which they dispersed those illustrious and holy recluses whom study and devotion had assembled at Port Royal, who made those great disciples, and to whom 
Christians will ever owe those famous works which have shed abroad so clear a light to distinguish truth from appearances, the necessary from the superficial, to enlighten faith, to kindle charity, to expand the heart of man, to guide his conduct, to hold up to him a faithful mirror, and to direct him between a just fear and a reasonable hope. To persecute these things to the bitter end, was what the devotion of the King prescribed, and that of Madame de Maintenon, conformable to his own. (Saint-Simon, tom. xiii. p. 2r.)

This language would have been applied to the King by no other man of that Court. To the high spirit of Louis in adversity, and to the dignity of his manners on all occasions. Saint-Simon does justice; but he had sounded and found wanting his capacity and his heart. 'Le Roi connaissait peu les lois de la nature et les mouvemens du cœur humain. Le Roi dont l'amitié n'allait pas jusqu'à la contrariété. C'était un homme uniquement personnel, et qui ne comptait tous les autres, quels qu'ils fussent, que par rapport à soi. Sa dureté là-dessus était extrême ...' How little Louis knew, amidst all that obsequious circle, which hand was to write his most enduring epitaph!

Two and twenty years of the life of Saint-Simon were spent at the Court-almost daily in the presence - of Louis XIV.; but they were spent in what, in the language of Princes, is called 'disgrace.' $\mathrm{He}$ was honoured with no distinction which could be 
withheld from him. If his wife received a mark of favour, it was rendered cutting and insolent by the exclusion of the husband. In the public service he was never employed by the King. It is not clear that he ever had more than three conversations with Louis ; and two of these were at audiences granted on his own demand, for the purpose of self-defence. The splendour of those royal rays served but to cast a deeper shadow over the solitary apartment of SaintSimon; yet, to borrow a metaphor from the practice of a modern art, it was within that dark veil that the scenes and figures of the Court were projected on a canvas destined to retain them for ever.

But, in one word, Saint-Simon remained, even in the midst of that servile flock answerable to the call of their imperious master, a Man of Independence. Neither the favours nor the frowns of power turned him aside from the straight path, or shook that selfrespect which was his highest distinction. In early life he had served with gallantry in three campaigns, and the career of arms seemed naturally to open before him. But he was slighted in a promotion: he laid his case before Vauban and some other friends : they told him he had been ill-used, and he threw up his regiment, to the unmeasured surprise and displeasure of the King. To quit his service, 
on a plea of personal dignity, was an act which Louis had not the spirit or the generosity to forgive. At a later period, when the armies of the King, commanded by incapable generals, and starved by incapable ministers, had entered upon their long course of humiliation and defeat, Saint-Simon laid a wager that Lille would not be relieved. When the story reached the King, it was represented as little short of treason for a man of Louis' own Court to bet against the fortunes and the flag of France. Saint-Simon had the courage to demand an audience, and, with the dignity and loyalty of an honest man, to tell the King his motives. They were not ungraciously received, for Louis was perhaps astonished to see one of those who surrounded his presence standing there erect before him. But they served not to remove the King's prepossessions and fears. From that day forth Saint-Simon was a marked man. He was supposed 'to have views;' he was known to utter caustic speeches; his searching eye, when he was silent, inspired as much terror as his tongue when he spoke. Even the passionate eagerness with which he defended the privileges of his order was unwelcome to the King, who cared for no privileges which were not badges of his own service. It was, moreover, the fate of Saint-Simon to enjoy 
the confidence and the affection of every one whom the Court most hated and feared - of the Duc d'Orléans, the antagonist of the Duc du Maine-of the men and women most suspected of Jansenist principles, and most known by the severity of their principles. Whatever of opposition could exist in the Court of Versailles centred in his person, and the King seems to have felt, with a keen presentiment of antipathy, that it would one day break forth to hold up his own foibles and vices to the contempt and execration of posterity. No doubt, characters of this stamp are guarded and fenced about with .. pride. Saint-Simon might have said with Pope-

\footnotetext{
'Yes, I am proud : I must be proud to see Men not afraid of God, afraid of me.'
}

But that pride is hallowed which restrains a man from low indulgences or base compliance. The light which glittered on the plumage and the tinsel of such men as Dangeau was all reflected from the person of the King; the lustre which still surrounds the name of Saint-Simon shone from himself alone.

It has been said by writers of the present day that, after all, with great pretensions to political sagacity and knowledge of affairs, Saint-Simon was no statesman, and that the only official function he 
performed, even under the favour of the Regent, was a ceremonial embassy to Madrid. But SaintSimon was one of those men who are content to make their influence felt on public affairs without assuming the credit of it. Viewing with horror and aversion the ruinous decline of the monarchy, and anticipating from afar its dissolution, if the course of events was not turned aside, he applied himself, in conjunction with the most illustrious of his friends, to form the political principles of the heir to the Crown, the young Duc de Bourgogne, whose natural ferocity and pride had been effectually subdued by the benign authority of Fénelon. Was there another man at the Court of Versailles who would have inculcated on the future sovereign of France that kings are made for their subjects, and not subjects for kings; who would, in I $7 \mathrm{I} O$, have pointed to the States-General as the sole hope of the nation; and have contended that the strength and security of the ruler lay in the constitutional limitation of his power? The death of that young Prince, under the most affecting circumstances, blighted a world of fair hopes and generous designs : perhaps it may be said that this event did at last cost the House of Bourbon its throne. Had it been otherwise, the principles of Saint-Simon might have governed 
France, and with the changes that experience would have wrought in them, a lasting Constitution might have grown up in the French nation. But the Nemesis of the reign of Louis XIV. prevailed, and on the King's death the crown descended to a child, with such a Regent as the Duke of Orleans.

No man knew better than Saint-Simon the unutterable weakness and viciousness of that wretched being, for no man had struggled with equal boldness to combat his propensities and his errors. But in spite of his faults, Saint-Simon loved him; and even during the dark and evil days of the Regency, he retained the confidence and respect of the Prince, though he opposed his policy and abhorred his associates. It was Saint-Simon who took the leading part in that memorable act of the Parliament of Paris which set aside the late King's will and crushed the pretensions of the Duc du Maine : that day, indeed, his vengeance was complete, and he does not dissemble the joy with which he triumphed in his hatred. But when Law and his system enriched the parasites of the Palais Royal, and prepared the ruin of France, there was one man at least whose hands remained pure, who absolutely resisted the entreaties of the Regent to accept any part in the boundless treasures of the Mississippi adventure; 
and who, from the first, denounced these mad speculations as the dreams or the frauds of a charlatan. With equal firmness he opposed the abominable ascendancy of Dubois, who polluted the Roman purple; and he protested against the policy of the Regent in his alliance with George I. and his rupture with Spain. Never was a bolder remonstrance addressed to a Prince than when Saint-Simon reminded the Regent that, in the event of the young King's death, and of a disputed succession, the pretensions of Philip V. were formidable, since the line of Anjou came before the line of Orleans, and it was not safe to trifle with the feelings of a nation accustomed to respect and obey the elder branch of its princes. ' Nay,' said he at last to his master, ' much as I am devoted to your person, I know not whether, in the event of such a claim being preferred, I should myself be able to stand by you!' These are no common examples of political sagacity and courage ; and, although he did not publicly assume the direction of affairs, Saint-Simon hesitated not to tell the Duc de Noailles that assuredly no one but himself should be Prime Minister.

In the course of this voluminous narrative, there is one quality to which Saint-Simon does not lay claim-he admits that he has not the gift of impar- 
tiality; he acknowledges that he delights in men who are honest and true; that he scorns the scoundrels who abound in courts; and that he hates those who have done him harm. But he pleads that his sympathies are ever on the side of virtue, and against vice; and that his own affections and aversions have not been allowed unduly to sway his pen, or to impair the absolute purity of truth and justice.

If ever these Memoirs see the light of day (said their author, with a solemnity of manner which marks the concluding touches of his pen), I doubt not that they will excite 'une prodigieuse révolte ' [a word which may perhaps here be translated ' revulsion']. Everyone looks to his own, his own interests, his own claims, his own dreams, and nothing that is his own can suffer contradiction. One's love of truth is measured by one's favour, and truth has no favour for such things as these. Those who are well spoken of thank you not, for truth required it. Those, in greater numbers, who are not so spoken of, are the more furious as the evil is proved by facts ; and at the time when I wrote, especially towards the end, everything was turning to decline, to confusion, to chaos, which has since only gone on to increase; and as these Memoirs breathe only order, rule, truth, fixed principles, and lay bare whatever is opposed to them, which reigns more and more with a most ignorant but absolute dominion, so the convulsion cannot fail to be general against this mirror of truth. (Saint-Simon, tom. xx. p. 92.)

Were it not for his passionate sympathy with the good and his passionate hatred of the evil, SaintSimon would not be one of the greatest of satirists ; but it must be confessed that the charity which 
throws a veil over the follies and weaknesses of others was not among his virtues-nay, he disdained even to conceal his own. His work therefore remains not altogether free from inaccuracies, though these are marvellously infrequent-not coherent in form, or correct in style; not free from personal vanity and personal malice; but representing with masterly fidelity a large epoch of human history, illuminated by the power of genius and the love of truth. In the variety and force of his characters Saint-Simon is Shakspearean; and no drama can surpass in turbid grandeur the mingled scenes of comedy and grief which he drew from life. But of all the characters he has delineated none exceeds in interest his own; for it is that of a consummate gentleman, who remained pure when most men were corrupt, and erect when all men were prosate. 
MIRABEAU. 


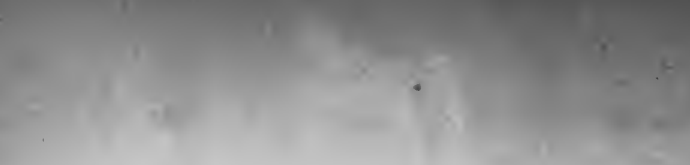

1
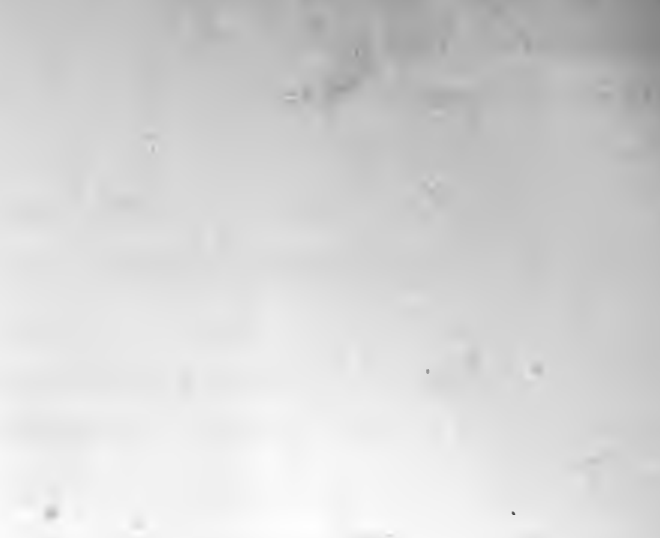

.
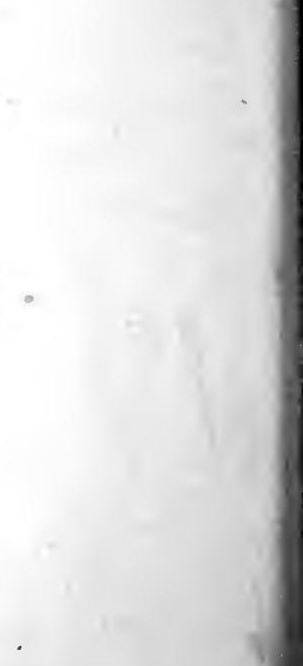


\section{$M I R A B E A U^{1}$}

M. ThiERs observed, in a note to the first volume of his 'History of the French Revolution,' published upwards of twenty years ago, that the particulars of the conduct of Mirabeau towards all the several parties with which he had been connected were not yet accurately known, but that they were destined ere long to be so. M. Thiers added, that he had obtained positive information from the persons who were to publish these particulars, and that he had actually seen the important document, in the form of a political confession of faith, which was the secret treaty of Mirabeau with the Court, but that he was not at liberty to print any of these papers, or even to name those who had the

1 This paper was first published in the Quarterly Review, No. 178, for September 185I. Some passages were slightly modified, and some additions made to that article, by the late Mr. Croker, whose knowledge of the details of the French Revolution was most extensive and accurate. But as these emendations were of small importance, the essay is here restored to its original form. The work reviewed is the Correspondance entre le Comte de Mirabeau et le Comte de la Marck pendant les années 1789,1790 , et 1791 , recueillie, mise en ordre, et publié par M. de Bacourt. 3 tomes. Paris, 1851. pp. 1498. 
custody of them. He could only affirm what would be sufficiently demonstrated when the whole of this information should be published.

After the lapse of a period far longer than was then contemplated by M. Thiers, or than had been contemplated by Mirabeau himself at the abrupt close of his tempestuous existence, the publication of the volumes now before us has redeemed this pledge, and placed before the world very complete and authentic evidence as to the secret political views of Mirabeau, and especially as to his relations with the Court, during the first period of the French Revolution. Dark and hateful as were those days which let loose upon France and the world all the worst passions of mankind, they present an eternal subject of inquiry and meditation to him who would read the history of the world amidst the convulsions of this age. These volumes re-open the frightful prospect. They show that, of the greatest calamities and horrors, none were from the very commencement $\checkmark$ unforeseen. They show by what fatality these evils,

$\checkmark$ though foreseen, were not averted. Above all, they exhibit, stripped of all disguise, that profligate, ambitious, and irregular spirit, which burned like a meteor at the approach of this tempest-eager for power, eager for luxury, eager for gold-mingling 
the coarse pursuit of sensual enjoyment with schemes for the regeneration of an Empire-at once a demagogue in one place, and a courtier in anotherfanning the flame in public which he professed in secret to quench, and describing with infinite sagacity and unmeasured force the amount of the calamities which his own eloquence and example only rendered more terrific and inevitable. To reconcile these inconsistencies; to vindicate the conduct of Mirabeau from the indelible stain which rests upon his genius, and lowers his public career almost to the level of his private vices; and to present a definite apology for his tortuous policy and conduct, is a task beyond the power of the biographer. But a curious combination of circumstances, to which we shall presently advert, has preserved to us materials connected with this eventful period which are beyond suspicion. Posterity may draw from the correspondence of Mirabeau with the Court what inferences it will, but these mysterious documents are now at least in their full extent before us. Nothing more real or more genuine has been rescued from the great convulsion which was so soon to overthrow the monarchy of France-nothing more vividly characteristic of the real spirit of that Revolution from its first commencement; of its authors, who worked a ruin far VôL. I. 
beyond their intentions ; of its victims, who suffered evils so immeasurably beyond their deserts. A few months after the commencement of this short but momentous correspondence, he, whose fervid and reckless nature addressed these appeals to the terrors of the Court and the policy of the Queen, was already a corpse on the threshold of that revolution from which he saw and was to find no exit. The other parties to this occult transaction, who had engaged in it from attachment to the Queen, and with some hope of attaching Mirabeau to her service, were scattered over Europe, and were to revisit the gay circle of the Trianon no more. Louis XVI., lost in apathy, and incapable of a resolutionMarie Antoinette, roused to efforts of which she had long seemed incapable, remained alone to face $\checkmark$ destruction. The life and death of Mirabeau, flung like an episode across the first act of the French Revolution, foreshadowed the whole catastrophe. In England the sagacity of Burke already at that period discerned the character of that pestilence from the false halo which had at one moment surrounded its approach; and that discovery rent asunder the ties which had existed between Burke and his political friends. In France Mirabeau had seen as far and feared as much. He, too, discovered 
nothing between the National Assembly and the future but the annihilation of the monarchy-the destruction of the King. But these forebodings $V$ seemed only to rouse him to greater ardour, to excite him to keener virulence, to stimulate his personal jealousies and his insatiable ambition, and even to mask the precautions he laboured, in the disguise of the Jacobin Club, to enforce on the Court. It was the strange fate of Mirabeau to denounce to the Court the hollowness of all the assurances on which it still relied against the Revolution, which he was urging forwards; and now, sixty years after the event, he denounces to posterity in these papers, destined for the private eye of Marie Antoinette, the hollowness of the revolution he affected to have made, and the worthlessness of the rivals in its favours whom he was endeavouring to supplant. Nor, if he relied on these papers for his justification with posterity, as he expressed it in the closing hour of his life, can he have been insensible to the fact that these memorials of his secret policy were the strongest condemnation of his public acts, and that the false popularity which surrounded the hero of the revolutionary Assembly must be stripped off before history could recognise in him the fidelity or the sagacity of a servant of the Crown. 
The history of these papers is so singular that it is requisite we should introduce to our readers the secondary personages of this romantic narrative before we proceed to examine the documents they have handed down to us. The volumes now before us have been edited with care and good faith by M. de Bacourt, late Minister of France at the Court of Turin, and who formerly filled an office connected with the French embassy in this country. It was, we believe, upon the recommendation of Prince Talleyrand, who took an interest in the earlier stages of M. de Bacourt's career, that the Prince d'Arenberg, known at the period to which these papers relate by the title of Count de la Marck, was induced to confide to this gentleman, about twenty years ago, the deposit he had himself received from Mirabeau on his death-bed. Prince d'Arenberg never accomplished his purpose of completing this publication, which he had suspended until the last actors in the scenes of I79I had disappeared; but he prepared a succinct and dispassionate narrative of the transactions in which he was so singularly engaged; and this memoir now forms the introduction to this correspondence, and gives it the stamp of the highest authenticity. By an undeserved piece of good fortune, Mirabeau's posthu- 
mous vindication (if so it can be called) is placed under the care and produced upon the testimony of a witness whose whole life was above suspicion and free from reproach. He survived by half a century the scenes of I79I; he surveyed them in the maturity of years with an abundant store of contemporary evidence, in which he found more misrepresentation than fidelity or precision. He transmitted the completion of his task with the original MSS., which are all in existence, to a gentleman of known reputation; and, in accomplishing, at this distance of time, the last intentions of Mirabeau, the turbid stream of a depraved and ambitious life loses much of its impurity by the tranquil and transparent medium through which it comes down to us. At the same time the language of M. de la Marck in his later years cannot efface the recollection of the part he was himself disposed to take at the outset of the Revolution. His attachment to the person of the Queen was strangely balanced by his intimacy with a man whose profligacy, obscenity, and utter $\checkmark$ want of honour were notorious to all Europe; and we are sometimes embarrassed to know whether the facility with which he passes over transactions of the most scandalous inconsistency with Mirabeau's personal engagements to himself and to the Court is 
to be set down to the account of simplicity or bad faith. He was certainly frequently made the dupe of his formidable ally; he was sometimes degraded into becoming his tool: whilst Mirabeau speculated on the integrity of his name and the depth of his purse.

I have been placed, says M. de la Marck, in this introduction, on a theatre where the actors were extremely conspicuous; I have been intimately connected with some of the most celebrated of them. I have known Courts and the world. From observing the manner in which the esteem of mankind is distributed, and the motives for which it is conferred, the facility with which it is sometimes caught by intrigants, whilst it is often refused to the good, I learned that it must often be taken at a lower value than is commonly imputed to it; but I have felt at the same time that the one thing needful was to be at peace with oneself, and to live within the domain of one's own conscience.

For the last twenty years we have been inundated with Memoirs on the Revolution and the times in which I have lived. These examples would perhaps have deterred me from writing, but I am reminded that if this indifference be allowable for myself, I have not the right to extend it to others; and that, possessing the means of confuting calumny, I should seem to sanction it if I withheld them from publication. But the supreme reason which has decided me is the engagement I had contracted with Mirabeau himself on his death-bed, to submit to posterity the evidence of the cause in which his memory is at stake, and to bear the testimony which is due from me to his energetic and loyal efforts to save his country and his king. I shall publish nothing in my lifetime; but at least these materials will be found after me, and I shall leave it to others to make a suitable use of them. Truth never comes too late for history. 
The Count de la Marck, subsequently known as Prince Augustus d'Arenberg, was the second son of the head of the sovereign house of that name, born in Brussels on August 30, I753. His father had distinguished himself in the Seven Years' War, and became early in life a field-marshal in the Imperial service, and one of the original knights of the Order of Maria Theresa. His family was thus closely connected with the Court of Austria, then sovereign in the Low Countries, and, on the other hand, the last Count de la Marck from whom he was descended, offered to transfer to the offspring of his daughter, the Duchess d'Arenberg, a regiment of German infantry which had been raised by his predecessors for the service of France in the time of Louis XIV. This offer was accepted for the young Prince Augustus, who accordingly took the regiment and the title of his maternal grandfather, and passed into the military service of France, though, as a prince of the Empire, he was not, strictly speaking, a subject of that or any other Power. The assent of Maria Theresa was required to sanction this arrangement. It was the moment at which the Archduchess Marie Antoinette was on the eve of concluding those brilliant nuptials which, were the false harbingers of the greatest tragedy in the 
annals of kings. The young Austrian soldier was suitably recommended to the Court of the youthful Princess, who, like himself, had just adopted France as her country; and when he entered the gay society of Paris, where he was allowed by the Court of Spain to enjoy the rank of grandezza, which made him the equal of the highest class of French nobility (for his German rank would not have been recognised at the French Court), he easily obtained the regard and confidence of Marie Antoinette and of the circles which she honoured with the graceful intimacy of her happier years. It would be beside our present purpose, and it is somewhat beside the principal object of this book, to retrace the reminiscences of that polished but defenceless and improvident society upon which M. de la Marck dwells with natural predilection. The times already impending over it were such that the least irregular Court which France had ever seen was about to be denounced for the vices slanderously attributed to its chief ornaments, and the sovereign who more than any of his predecessors had governed for the sake of his people was already denounced as a tyrant and suspected as a traitor. But the life of the Court of France in the ten years immediately preceding the Revolution exhibited nothing that could 
prefigure that immense catastrophe. Even the Duke of Orleans is described by M. de la Marck as careless, weak, and humane, rather than as the deliberate enemy and ambitious rival of the Court, which he afterwards proved himself to be; and the cause assigned by M. de la Marck for this hostility - a mere matter of etiquette towards one of the Austrian Archdukes from the French Princes-is ludicrously inadequate to account for the reckless and abominable passions afterwards excited in the breast of Philippe Egalité. On one point, however, M. de la Marck is deservedly explicit. The correspondence contained in these volumes exhibits Marie Antoinette in the light of a political personage. To her the counsels and appeals of Mirabeau were addressed, and it was by her influence alone that this friendly conspiracy for the salvation of the monarchy was to act upon the irresolute mind of the King. The adoption of such means at a later period shows either to what shifts the friends of the Court were reduced, or that insult and danger had already roused in the mind of Mary Antoinette something of the spirit of her heroic mother. But in the first years of the King's reign the Queen had shown a marked repugnance to interfere in politics, and she had on more than one occasion refused to 
lend her influence to sway the Cabinet or the King in favour of the policy of her brother, the Emperor Joseph. Thus at the outbreak of the War of Succession of Bavaria in 1778 , the Austrian Ambassador was instructed to demand of France the contingent of 24,000 men promised to the Imperial Court by the treaty of 1756 . The Queen was appealed to by the envoy, but she refused even to mention the subject to the King. * In 1784 , when the affairs of Holland gave rise to an apprehension of war, Austria failed in like manner to obtain the active support of France, in spite of the most pressing appeals from the Emperor Joseph to his sister. Yet these very incidents were afterwards dressed up by all the arts of calumny; and the Queen was invariably represented as a foreign intrigante, ready to sacrifice the best interests of her adopted nation to the influence of her Austrian connections. She had committed, indeed, the unpardonable fault of admitting to her society, with marks of peculiar favour, some of the foreigners who frequented the Court; but on M. de la Marck's pointing out to Her Majesty that this predilection was liable to misconstruction, she replied, with affecting simplicity, 'It is true: but they, at least, ask nothing of me.' Still more dangerous to the reputation and upright- 
ness of the Queen was that rapacious and profligate society of the Polignacs into which she was fatally drawn. But to that society the Austrian party at the Court had never belonged. Count de Mercy, the Austrian Ambassador, rarely went there. Count de Fersen, who knew the Queen's real opinion of that circle, had always refused to join it. M. de la Marck speaks of it with unmitigated aversion.

It was not, however, in these frivolous and exclusive salons that M. de la Marck could ever have met Mirabeau, for the scandal of his vices was undisguised, and the violence of his opinions had long since estranged him both in manners and habits from the company to which he might from his birth have aspired. It was agreed, however, one day in the year 1788 , that M. de Meilhan, the intendant of the province of Hainault, should bring Mirabeau to a dinner at the house of the Prince de Poix, then governor of Versailles. The party consisted of M. de la Marck, the Tessés, the Viscount de Noailles, and some other persons. Mirabeau entered, and, with some astonishment, the party saw in him a man coarse in his person, overdressed, wearing a huge quantity of powdered hair, large coloured stone buttons to his coat, conspicuous for a profusion of bows, an excess of compliments, and, in short, an 
entire absence of that modesty and self-possession which belongs to high breeding and good taste. As the dinner proceeded the conversation took a political turn, and Mirabeau recovered all his advantage by the vigour and eloquence with which he discussed the topics of the day. M. de la Marck naturally exchanged some remarks with him on the politics of Germany, with which Mirabeau was better acquainted than his countrymen usually are. In spite of the extreme difference of the characters of the two men, they suited one another, and their acquaintance speedily ripened into a friendship, which remained unbroken till Mirabeau's death. That friendship is one of the few passages of his life which left him better than it found him, and still sheds some credit on his memory. It is obvious, however, that, in spite of the sentiment Mirabeau affected at times to throw over it, he had mainly sought and cultivated M. de la Marck, as he did every one else, for the use he could make of him, and it was a connexion in which all the services were on one side and all the exactions on the other.

Strange relations these to have sprung up even in that strange time between so great a favourite of fortune as Count de la Marck and one who had so little to thank her for as Mirabeau-the one a prince 
of the Empire, associated by birth, feelings, and opinions with the nearest interests of the Court; the other an outlaw, whose genius might force a breach in society, but could scarcely open a door in Paris : the one opulent, refined, a consummate gentleman; the other profligate, unscrupulous, coarse in his manners, and reckless in his conduct. For the existence of such an intimacy these volumes do not account, though they show how often and how sorely it was tried. It was not dictated on either side by mere political calculations, though Mirabeau had probably engaged in it with that object. There was between these men an eccentric predilection. The one had genius, without being able to regain the broad track of honour, or the station of duty; the other had virtue, but accompanied with boundless indulgence for the sins of genius, and a want of penetration of which Mirabeau certainly availed himself to impose largely on his credulity and his goodnature. Certain it is that through this eventful period they continued to live in constant intimacy, though their acquaintance brought neither to one nor to the other the political results each of them had anticipated.

The relations which had thus commenced in society were soon to be transplanted to a wider and 
a more agitated scene. Upon the convocation of the States-General, M. de la Marck was elected, though an alien, for the bailliage of Quesnoy, in which his wife's estate of Raismes was situated, and he sat, in fact, as the representative of the nobles of that district, most of whom resided in the Austrian Low Countries. It was not, therefore, until after the union of the Three Orders ${ }^{1}$ that Mirabeau met him in the National Assembly. Their conversation was resumed on friendly terms, and, shortly after, M. de la Marck invited the hero of the Jeu de Paume to dine alone with him in his private apartments. Mirabeau accepted, saying that, with an aristocrat like himself, he should always get on well. In fact, the natural bent of Mirabeau's mind, and even of his vices, was essentially aristocratic; but he was the chief of those traitors to their order who, in days of revolution, let in upon the State the passions they despise and the pretensions they reject. The description of this interview deserves to be cited :-

No sooner had Mirabeau entered the room than he said to M. de la Marck, 'You are displeased with me, are you not?'

${ }^{1}$ It is singular that M. de la Marck barely alludes to the first steps of the Revolution, and especially to the decisive step of the union of the Three Orders to which he himself, as a noble, assented, though it was in fact the immediate and violent subjection of the Upper Chambers to the Tiers État, and it was accomplished by menaces and treachery which ought to have removed all doubt from his mind on the line adopted by Mirabeau. 
'With you and with many others.' 'If that is the case, you should begin with those who live in the palace. The ressel of the state is struck by a most violent tempest, and there is no one at the helm.'

Mirabeau continued a long while in this strain, excited himself to fury against the faults already committed, and accused $\mathrm{M}$. Necker of incapacity and ignorance. He maintained that it was shameful for this minister not to have brought forward at the opening of the States-General a complete scheme of finance, adapted not only to cover the miserable deficit of r60 millions, but even to augment the revenue of the kingdom. He said, that, for such a country as France, it was a mere joke to accomplish this object; but that it required deeper views and bolder conceptions than those of M. Necker, who was, in his opinion, altogether below his position.

M. de la Marck, without discussing these weighty questions, contented himself with replying, "But what are you driving at, yourself, with the incendiary conduct you have adopted in the Assembly and out of doors?'

'The fate of France is decided,' exclaimed Mirabeau. 'The words Liberty and Taxes, voted by the people, have rung round the kingdom. We shall not get out of it without a Government more or less similar to that of England.'

In the midst of all this declamation and abuse of the Ministers, he still appeared to be a supporter of monarchy, and repeated that it was not his fault if he was repelled, and compelled for his personal safety to make himself the leader of the popular party. 'The time is come,' said he, 'when men must be valued by what they carry in this little space under the forehead, between the eyebrows.'

M. de la Marck vainly attempted to demonstrate to him that $\downarrow$ what he was saying neither justified nor excused the audacity of his revolutionary speeches; and that his eloquence, admirable as it was, was not worth the harm it did the country. 'The day 
that the King's Ministers will consent to reason with me,' answered Mirabeau, 'they will find me devoted to the royal cause and the safety of the monarchy.' 'But what,' rejoined his friend, 'is to be the end of the present state of things?' ' The ruin of France,' answered he ; ' and if the country is to be saved, there must be no delay in employing the only means that can succeed. The present system is absurd, insane. The Assembly is left to itself; and it is supposed either that it can be subdued by force, as the aristocratic party have it, or brought round by the hollow and redundant phrases of M. Necker. What is wanted is, that the Government should seek to form a party in it by means of men who cuuld influence, excite, or calm it,'

It was at the end of the month of June I 789 , a fortnight before the attack on the Bastille, that Mirabeau held this language, and he expressed to M. de la Marck his desire frequently to repeat their private interviews. Enough had already been said on this occasion to strengthen the profound apprehensions which the first blast of the Revolution had excited in the minds best qualified to judge of it ; and M. de la Marck perceived the advantage to be derived from a close observation of one who was destined to act so $\checkmark$ amazing a part in it. From this conversation, and from every succeeding incident in the political career of Mirabeau, in as far as it was connected with M. de la Marck, it is easy to perceive that the great tribune of the people and the chief revolutionary orator of the Assembly was playing elsewhere a totally different 
game $;^{1}$ and that his schemes were from the very out set of the Revolution quite as much directed to the acquisition of ministerial power on the one side, as of popular influence on the other. Acting partly on the fears and partly on the hopes of the Court ; irreconcileable towards a Minister like M. Necker, whom he felt it necessary to remove; alternately servile and insolent to Lafayette and Montmorin, whom he hated and despised as much as he did Necker, but whom he hoped at times to convert into the instruments or coadjutors of his own schemes; Mirabeau invariably exhibited himself to M. de la Marck, and is conse-

1 We shall not attempt to adduce in detail the voluminous evidence of the numerous contradictions and inconsistencies which might be opposed from other sources to M. de la Marck's narrative. But at this very moment-the commencement of July 1789 -there is ample and authentic proof, both from the language and the public actions of Mirabeau, that he was playing a double game. It was at this same time that he said to M. Mounier, who related the interview which took place in one of the bureaux of the Assembly, and to M. Bergasse, who was present,- ' Gentlemen, I met the Duke of Orleans yesterday and said to him, "Monseigneur, you cannot deny that we may soon have Louis XVII. instead of Louis XVI., and in that case your Royal Highness would be at least Lieutenant-General of the kingdom." The Duke of Orleans, gentlemen, answered me very curtly.' It was at this same time that he was seen working with Rugot and Robespierre to breed dissatisfaction in the Assembly at the King's assurance that the Assembly had nothing to fear from the troops; and when Mounier accused him of tampering with the army, he replied,- ' My good fellow I am as attached as you are to the throne, but what does it signify whether we have Louis XVII. instead of Louis XVI., and why do we want a baby to govern us?' Above all, on July 9, he produced the memorable address to the King demanding the dismissal of the troops from Paris, which was followed by the measures that covered France with National Guards, and by the attack on the Bastille!

VOL. I. 
quently exhibited in this correspondence, as a man $\checkmark$ eager to take the government on the footing of a constitutional minister, and resolved, if he should succeed in this enterprise, to devote himself to save the monarchy, in whose ruin he foresaw that the whole established order of things, the royal family, $\checkmark$ and probably he himself must perish. He was not ignorant of the enormous obstacles which his former life, his present violence, and his whole character presented to the execution of such a scheme. He more than once exclaimed to his friend how bitterly he lamented the injury which the immorality of his early life was doing to the State. He clung with the utmost tenacity to every chance which seemed likely to obtain for him the reluctant confidence of the Court; and we shall presently see to what a strange series of coadjutors and intermediates he successively committed himself in the hope of obtaining the direction of affairs under the shelter of some purer name. But, however eager he might be to pursue this track, on which, except from M. de la Marck, he met with little encouragement, he seems not to have felt that the chief barrier lay in his own conduct since the meeting of the National Assembly, in his suspected relations with the guiltiest instigators of those first days of bloodshed and insult to the Crown, and in the fact that, if he meant well to the 
Court, he certainly was playing a game doubly false to the people. With these considerations present to her mind, and heightened by the aspersions which identified the great orator with all that was most fierce and personally hostile to herself in the Revolution, it is not wonderful that the Queen, to whom these appeals were mainly directed, recoiled from a prospect of safety proffered by such hands. In September I 789 M. de la Marck caused the Countess d'Ossun, a lady in waiting and a favourite of Marie Antoinette, to explain to Her Majesty the object and intentions with which he continued to cultivate the friendship of Mirabeau. The Queen herself shortly afterwards took notice of this communication: 'I have never doubted,' said she, 'of your sentiments; but I think we shall never be so unhappy as to be reduced to the painful extremity of having recourse to Mirabeau.'

It is not, therefore, to these volumes that we must look for the counterpart of the intrigues in which Mirabeau was here engaged; for unhappily the estimate we have long since formed of his character does not lead to the inference that, because he had secretly adopted one line of policy, he had bona fide and entirely abandoned the other. Certain it is that throughout this period, and to the close of his life, 
even after Marie Antoinette had found herself reduced to the painful extremity of listening to his advice, his language in public was to the last degree offensive and dangerous; sometimes his votes were hostile-even when he protected, his attitude was menacing. So that, without contesting the sincerity of the opinions he professed to M. de la Marck in the intimacy of private friendship, and the soundness of the advice he actually tendered to the Court,these and all the advantages of his genius and his $\checkmark$ foresight were tainted with duplicity; and history will not acquit a public man of great crimes because they were perpetrated openly, whilst he was protesting in secret against the policy he affected to pursue.

On one point, however, M. de la Marck's testimony assumes a more direct character, and if he does not absolutely disprove, he certainly discredits, the imputation on Mirabeau of secret relations, hostile to the Court, with the Duke of Orleans. $\mathrm{U}$ p to the middle of the year I 788 , he assures us that these two personages had never met. The Duke requested $M$. de la Marck to make a dinner for the purpose of introducing him to Mirabeau. The party took place, but it was unpleasant; the principal guests were ill pleased with one another, and Mirabeau observed some days afterwards to 
his host, that, as for the Duke, he 'neither liked him nor trusted him.' The question, then, is narrowed to this point: whether, between the period immediately preceding the opening of the États Généraux and the $5^{\text {th }}$ and 6 th of October 1789 , the intimacy of Mirabeau and Égalité had ripened into a political conspiracy? To that supposition M. de la Marck gives a decided negative. He shows that at the very time when Mirabeau was suspected of drawing money from the Palais Royal, he was, in fact, so distressed that he threw himself on the generosity of his friend for a loan of 50 louis. M. de la Marck placed that sum at his disposal, not only on that but on several other occasions, only requiring of him a promise that he would not borrow elsewhere, and hoping that this friendly assistance might secure the independence of his opinions. But he goes beyond these inferences:-

In the conversations which I had every day with Mirabeau, I made him talk of the men who in those times seemed ready to march at the head of the Revolution, if not to direct it. He had a sovereign contempt for most of them, and thought little of $\mathrm{M}$. de Lafayette and the Duke of Orleans. Though it has often been repeated that he was led by the party of this latter personage, I can affirm, myself, that he never had intimate relations with the Orleans party. Laclos, who was the soul of it, knew men too well to give his confidence to Mirabeau ; and from the opening of the States-General, he had persuaded the Duke of Orleans that Mirabeau would be for the King. A short time before the days 
of the $5^{\text {th }}$ and 6th of October, the Duke of Orleans came to dine with me at Versailles with Count Mirabeau, and I clearly saw that there was a reserve between them which excluded the supposition of a secret understanding, for they had neither of them, at that time especially, any interest to deceive me. Indeed, a few days afterwards, I was confirmed in my opinion by a question of the Duke of Orleans, who asked me suddenly and abruptly, 'When will Mirabeau serve the Court?' I avoided answering in such a manner as to prolong the conversation, and merely said, ' At present, I think he has not taken the road to get there.'

We are compelled, by his own avowal, to impute to M. de la Marck less perspicacity than to Laclos, who, as he says, 'knew men too well to give his confidence to Mirabeau ; for this passage does not relieve the amiable writer from a suspicion that he" may have been imposed upon. It is not true that neither Mirabeau nor the Duke of Orleans had at that time any interest to deceive him, for to deceive him was to deceive the Court; and the least appearance of intimacy on the part of Mirabeau with the Duke would have been a glaring contradiction to all the assurances he was in the habit of giving to his friend in private. If any such intimacy did exist, it would have been disguised under an appearance of reserve, and nowhere more carefully disguised than at M. de la Marck's table, whom both parties knew as the Queen's attached friend.

The remainder of the passage relating to these 
events is, however, so striking and positive that, without closer inspection, it would go far to remove the doubt still lingering over them.

The state of affairs became more and more alarming. Towards the end of September 1789 , Mirabeau was always repeating to me, in speaking of the Court, 'What are those people thinking of ? Don't they see the chasms opening beneath their feet?' Once, indeed, roused to more than ordinary exasperation, he cried out, 'All is lost! The King and Queen will perish-you will see it. The populace will scourge their corpses;' and remark 'ing the horror this expression caused me, he added, 'Yes, will scourge their corpses. You don't enough understand the dangers 'of their position, yet they ought to be made known to them.'

Did his penetration already embrace the horrible events of the $5^{\text {th }}$ and 6 th of October? It would seem so; but it was not tor me alone that he thus expressed himself; he concealed from no one his opinions and his fears. Hence his enemies, and, perhaps, many who were not his enemies, were led to say that he had prepared the movement of the 5 th of October, and had played the chief part in it. The subsequent procedure of the Châtelet against Mirabeau was founded in great measure on conversations he had held before that catastrophe. Indeed, the most profound obscurity still veils the true instigators of that event. On the $4^{\text {th }}$ of October Paris was in the utmost fermentation; a report was circulated that the banquet of the guards was the commencement of a plot for the destruction of the Assembly. The morning of the $5^{\text {th }}$ of October was, however, quiet at the Château of Versailles. The King went out shooting, without paying much attention to the alarming news from the capital; and he only returned in the evening amidst the shots which the mob of Paris was firing on the guards in the great avenue of Versailles.

If Mirabeau had been guilty of the crime of which he was accused, it was, in the morning of that day that he must have 
concerted with his pretended accomplices to direct the movement and avail himself of it; but, instead of assisting at those councils of attack and defence, Mirabeau passed with me the day of the $5^{\text {th }}$ October till six in the evening. We dined together alone, and discussed the affairs of Brabant over a map of that country, though the greater part of our conversation turned on the dangers of the Court and the agitation then reigning in Paris. We were, however, still ignorant of the coming events of that day. All that Count Mirabeau said bore the stamp of that skill and vigour which the circumstances required, and it would have been well if the subject had been treated in the King's cabinet as it was by Mirabeau at my house. In all he said he spoke not the language of faction, but of a great citizen; and I affirm, from the bottom of my conscience, that this man was entirely a stranger, in his intentions as well as in his actions, to the intrigues which excited so violent an effervescence in the city of Paris.

It would certainly imply an astounding amount $\checkmark$ of duplicity and artifice that a man actually engaged in the preparation of an atrocious conspiracy, then about to take a (sanguinary vengeance on the Royal Guards for the boisterous loyalty they had displayed at the banquet of October I) should pass the very hours during which the mob of Paris, headed by its female fiends, was marching on Versailles, in discoursing with a faithful adherent of the Court on the perils even then impending over the Royal family, $\checkmark$ and the mode of averting disasters of which he was himself the contriver. But what was the public conduct of Mirabeau at the close of this conversation? 
It was then six in the evening, and M. de la Marck conveyed him to the Assembly. The particulars related by M. de la Marck as to the occurrences of the $5^{\text {th }}$ and 6th of October are greatly at variance with the accounts given by all other contemporary writers and especially with the narrative adopted by $M$. Thiers. That historian states: 'Il etait onze heures du matin; on apprend les mouvements de Paris. Mirabeau s'avance vers le Président Mounier: "Paris," lui dit-il, "marche sur nous. Trouvezvous mal, allez au château, dire au Roi d'accepter purement et simplement." “ Paris marche?-tant mieux!" répond Mounier. "Qu'on nous tue tous -mais tous-l' État y gagnera." “ Le mot est vraiment joli," reprend Mirabeau, et il retourna à sa place. La discussion continua jusqu'à trois heures,' \&c. M. de la Marck states, on the contrary, - Mirabeau passa avec moi la journée du 5 octobre jusqu'à six heures du soir. Nous dinâmes chez moi tête à tête,' \&c. 'Ce jour-là donc, le 5 octobre, après nos longues conversations sur les circonstances du moment, je conduisis Mirabeau à six heures du soir à l'Assemblée, et c'est là que nous êimes pour la première fois connaissance de l'approche de la populace de Paris.' A flat contradiction of the assertion that the approach of the mob was known and com- 
mented upon in the Assembly at eleven in the forenoon. But M. de la Marck says nothing of the morning sitting of the Assembly, which had opened at eleven, and adjourned at three, to resume at six. Does he mean us to infer that he and Mirabeau were there together, and so spent the day in company, or that they spent it in private? The latter might be supposed, if it were not well known from the above anecdotes, and from other sources, that Mirabeau $\checkmark$ was at the morning sitting. If so, it is difficult to conceive how the events of Paris, which had been in preparation during the whole of the preceding day, should only have been known at Versailles at six in the evening; and if $M$. de la Marck be wrong on this essential point of the time, the value of his evidence is considerably shaken. It distinctly appears, from all the other narratives we have been able to examine, that the mob began to arrive at Versailles between three and four o'clock in the afternoon of the 5 th, and that Mirabeau had conveyed his knowledge of its approach to Mounier four hours sooner. The weight of the evidence, as well as of probability, is so decidedly in favour of the earlier hour, that we can only suppose M. de la Marck to have been mistaken in his recollections of the day or to have been deceived by Mirabeau : yet it will be observed 
that his disculpatory declarations to the Queen and to posterity rest entirely on the incredible assurance that Mirabeau knew nothing of the approach of the mob till six in the evening.

At six o'clock, however, according to M. de la Marck, in the gathering dusk of an October evening, the first signs of the appalling night which was to follow were already perceptible, and the angry crowd rolled onwards towards the palace. Mirabeau entered the Assembly, where the King's message, $V$ implying his qualified acceptance of the projected constitution and the Declaration of the Rights of Man, was then under discussion and was vehemently attacked by Robespierre. Mirabeau rose, not to defend the Court, but to denounce what he termed 'those pretended fraternal banquets which insult the misery of the people, and throw sparks on materials already too combustible.' Pétion was called upon to sign and lay upon the table his denunciation of the proceedings at the military banquet. Mirabeau exclaimed, with terrific energy, 'that he regarded $\checkmark$ that denunciation as supremely impolitic, but that he himself was ready to furnish the details and to sign it, provided the Assembly would declare that the person of the King is alone inviolable, and that all other persons in the State, whoever they may be, are 
equally subject and responsible to the laws.' The Assembly was electrified by this appeal, which was understood to cover a direct attack upon the Queen, and the denunciation was withdrawn. But not a word in that place and at that moment of dangers which were to end, ere morning dawned, in brutal massacre; not an attempt to support even the dignity of the Assembly, whose sitting was interrupted by the irruption of Maillard at the head of a band of infuriated viragos! On the following day the Royal family were dragged to Paris, and Mirabeau took the step, prudent in any case, of causing the Assembly to decree that it was inseparable from the $\checkmark$ person of the sovereign. (Yet at this very moment Mirabeau applied himself to the composition of the first of the confidential papers intended for the use of the Court, which form the most curious portion of this collection; and on October I 5 , the note of which we shall quote the most striking passages was placed by its author in the hands of M. de la Marck to be communicated to the King. It will be observed that it is dated two days after the sudden departure of the Duke of Orleans for England and Mirabeau's well-known speech, ' $I$ take him for my master? I would not have him for a valet.' At that moment all connection between the two personages-if any 
such had existed-was undoubtedly broken, and was never renewed. The description of the deplorable position of the monarchy is extremely powerful and just, and the suggestion for its rescue was that to which Mirabeau uniformly adhered.

The King was not free to come to Paris, and whether the Assembly was or was not free to follow him thither, it certainly had not the power to save him from going there. Is then the King free in Paris? He is so far free that no other will prevails over his own, but he is certainly not free to quit Paris; he is not free to choose the guards of his person; he has not even the direct command of the militia to whom his safety is entrusted. Nor can it be said that the personal safety of the King in Paris is complete. Placed as he is, the smallest accidents may compromise that safety, which is menaced by movements from without, by commotions within, by the divisions of parties, the faults of zeal, those of impatience, and, most of all, by a violent collision between the capital and the provinces. If Paris is powerful, it also contains great causes of disturbance. Its excited mob is irresistible. Winter is approaching, subsistence is scarce, and a bankruptcy may ensue. What will Paris be in three months? Certainly a hospital, perhaps a theatre of horrors. Is it there that the Head of the nation can deposit his own existence and all our hopes?

Still more fatal events are in preparation. The National Assembly, so ill-composed from the first, finds the confidence of the country in its labours daily decreasing. The best intentions cannot avert errors. The Assembly is borne beyond its own principles by the fatal irrevocability it gave to its first decrees, and as it can neither contradict itself nor recede, its own power is an obstacle the more. The respect inspired by a great name and 
a great revolution seen from afar, and those hopes which are so necessary to a nation, still sustain it, but every day some portion of public opinion detaches itself from the great cause which required the individual concert of all parts of the empire. A dark commotion is at hand which may blast in a moment the fruit of the greatest enterprise. The body politic falls into dissolution; a crisis can alone regenerate it. It requires a transfusion of new blood. The only way to save the State and the infant constitution is to place the King in a position which may allow him to throw himself instantly upon his people.

He then proceeds to discuss in the same strain the various expedients which suggested themselves for this purpose. To retire upon Metz or any other frontier would be to declare war on the nation and to abdicate the throne. To retire into the interior of the kingdom and summon the nobles to join the royal standard would be not less dangerous. The plan which Mirabeau proposed was to contrive the organisation of a corps of 10,000 men on some point midway between Rouen and Paris, and that the Court should then leave the capital in the face of day, and retire upon Normandy, which was by position and character one of the most trustworthy parts of the kingdom, and might, in conjunction with Brittany and Anjou, present considerable military strength : that this departure should be accompanied by a proclamation addressed to the people against the tyranny of the mob of Paris, protesting that the 
King adhered to all his liberal intentions and engagements, and would fulfil them; that a new Assembly should shortly be convoked; and that the authority of the Crown was indissolubly united to the liberties and wishes of the people.

This document contains the substance of the advice Mirabeau uniformly tendered to the Court, and it must be supposed to express the opinion he really entertained at that time of the worthlessness of the Assembly and the brutality of the people of Paris. To surround the King with a competent military $\checkmark$ force in the heart of Normandy was then the recommendation of him who had called for the dismissal of the troops on the gth of July, and had not interposed to prevent the massacre of the guards on the 6th of October! But this royal exodus was to be $\checkmark$ accompanied by a declaration of policy in which it may fairly be inferred that he reserved to himself the largest share of actual power.

- M. de la Marck was not a little embarrassed by the receipt of such a communication. The Queen was exasperated against Mirabeau for his recent language with reference to the banquet of the Gardes du Corps and the suspicions which connected him with the recent outrage on her person. The King was inaccessible. At length M. de la Marck 
requested a private interview with the Count de Provence (afterwards Louis XVIII.), and was accordingly introduced to his closet in the dead of the night. Monsieur, for such was then his rank, listened to La Marck's strange story, and read the paperbut replied that the Queen had not influence enough to decide the King to act in a question of this gravity, and that as for the King his weakness and indecision exceeded all belief. "Figure to yourself as his character," added the Prince, 'balls of ivorv oiled, which you try to keep together.' After two hours' discussion the matter seemed hopeless, and we infer that this memoir never reached its destination. ${ }^{1}$ Some further intercourse, however, took place between Mirabeau and Monsieur through the Duc de Lévis, and amongst the fantastic plans subsequently entertained and abandoned by Mirabeau for the formation of a Cabinet, in which he

1 Camps, Mirabeau's private secretary, who had copied the memoir of October 15, was so alarmed at what he had done, that he was at one time on the point of divulging it to the National Assembly, by way of exculpating himself. M. Thiers has here been led into error when he affirms in his History (vol. i.p. 180) that the direct negotiation between Mirabeau and the Court was commenced at this time; that is, in October 1789. The attempted negotiation through Monsieur produced at that time no result; and M. de la Marck (who is M. Thiers' 'Prince Etranger') left Paris under the impression that it had altogether failed. It was in March I790 that the negotiation with the Court really commenced; and the first overture was made to M. de la Marck by M. de Mercy, acting under the orders of the King and Queen, as will presently be related. 
should take a leading part, one was to make the Count de Provence titular Prime Minister!

The ensuing weeks of November and December $\sqrt{ }$ I 789 were principally engrossed by the attempts of Mirabeau to come to an understanding with $\mathrm{M}$. de Lafayette in the construction of a cabinet based upon a coalition, and including the leading members of the revolutionary party. In spite of the aversion and jealousy which they entertained for one another, a serious attempt was made by Talon and their mutual friends to bring them together. Several personal conferences took place between them, and a note exists in Mirabeau's handwriting which reveals the scheme of this coalition government. Necker was to be the titular Prime Minister, the Archbishop of Bordeaux Chancellor, the Duke de Liancourt Minister of War, Talleyrand Finance, Count de la Marck himself Marine, Mirabeau in the Cabinet without a portfolio, Target Mayor of Paris, Lafayette Marshal of France and generalissimo for the reorganisation of the army. These projects, however, were as evanescent as they were vague. Even as early as the 7 th of November the Assembly $V$ had adopted the fatal resolution that none of its members could enter the Ministry during the whole period of the session. That resolution was avowedly vOL. I. 
aimed at Mirabeau, lest the influence of his parliamentary talents should be transferred to the service of the Crown. But that influence failed to procure the rejection of the measure most adverse to his designs. He ironically proposed his own personal disqualification, but the original resolution was put and carried against him, and from that moment the formation of a parliamentary Ciabinet became im$\checkmark$ possible. No decision could more effectually contribute to aggravate the Revolution than this, which left the Assembly without ministerial leaders and the Ministry without Parliamentary authority.

We return, however, to the direct relations of Mirabeau with the Court, as the most curious and novel part of the work before us. An interval of some months occurred from the $15^{\text {th }}$ of December I 789 to the I6th of March in the following year, during which M. de la Marck repaired to Brussels to attend to his own family affairs in the Low Countries. He was summoned back to Paris by M. de Mercy, then Austrian ambassador at the Court of France. He found Mirabeau on his return more than ever discouraged by the aspect of affairs, irritated at the failure of his ministerial projects, indignant at the incapacity of the Government, jealous of his rivals in the Assembly, and tormented 
by his creditors. In this state of things M. de la Marck was at once informed by the ambassador that he had been sent for by order of their Majesties - that the King and Queen had resolved to claim the services of Mirabeau, and that they charged La Marck with the entire conduct of this secret negotiation, which was not to be divulged even to M. Necker, who had entirely lost their confidence. A private interview was arranged at $M$. de la Marck's house in the Rue St. Honoré between Mirabeau and M. de Mercy, at which the former repeated his earnest recommendation that the King should withdraw from Paris, but not from France. On the following day M. de la Marck was instructed to attend the Queen in the private apartment of Madame Thibaut, her first femme de chambre.

The Queen began by saying that for about two months she and the King had taken the resolution of drawing nearer to Count Mirabeau, and that they had selected me for this purpose. She repeated what she had said some months before, that she had never distrusted my personal relations with Mirabeau; but she inquired, with a certain tone of embarrassment and curiosity, if I thought that Mirabeau had had no share in the horrors of the $5^{\text {th }}$ and 6th of October. I assured Her Majesty that he had passed those two days in great part with myself, and that we were dining together when the arrival of the Parisian mob was announced at Versailles. I added that I had wished at that time that the King's Ministers could have heard the opinions expressed at that tête- $\dot{a}$-tête, and still more that they could have acted upon them. 
'You give me pleasure,' answered the Queen, in a more confident tone; ' $I$ had great need to be undeceived on this point, for, from the reports current at the time, I confess I had retained a horror of Count Mirabeal, which has not a little contributed to retard our resolution to apply to him to check, if possible, the fatal consequences of the Revolution.'

At this moment the King entered. Without any preamble, and with his accustomed bluntness, he said, 'The Queen has already told you that I mean to employ Count Mirabeau, if you think that it is his intention and in his power to be of use to me. What do you think?'

I frankly answered the King that I thought this measure was taken very late, and I pointed out the extreme impolicy of his Ministers, who ought from the opening of the States-General (as they might then easily have done) to have rallied to the King's interests the deputies most remarkable for their talents, who had since become leaders of the revolutionary party. I said that Mirabeau himself had suggested some such overture, but that the Ministers had repelled him with an arrogant presumption which they certainly had no right to exhibit. I added, that there were many other deputies, dangerous men now, whose support might have been obtained, but that the longer the remedy was deferred the more difficult it became to destroy the evil.

'Ah!' said the King, 'there is nothing to hope on that head from M. Necker. All that is done by M. de Mirabeau must remain a profound secret from my Ministers, and I rely on you to secure it.'

I was confounded by this answer. I could not conceive how the King could expect to employ a man like Mirabeau without the knowledge of his Ministers. Indeed, the advice and the acts of such a man could not fail to be in direct opposition to those of the Ministry, and what good could come of such a contradiction?

'Now, then,' said the King, ' how do you think Mirabeau can serve me usefully?' 
I replied that I could only answer that question by referring it to himself, and I proposed that he should convey his suggestions to their Majesties in writing. The offer was at once accepted, and I retired, with leave to communicate with the Queen whenever I thought proper, but especially on the days when Madame Thibaut was in waiting.

It could not escape a man of M. de la Marck's delicacy and discernment, that this clandestine proceeding was not likely to be very honourable to those to whom such a proposal was addressed or very useful to those by whom it was made. $\mathrm{He}$ perceived at once that it was in fear rather than in confidence that the King and Queen had at last consented to address themselves to Mirabeau-that they hoped to buy him rather than to use him-and thought more of extinguishing his hostility in the Assembly than of devoting his services to themselves and the State. Nevertheless, he resolved to persevere in the $v$ hope that the advice which Mirabeau himself would address to the Queen might inspire their Majesties with sufficient reliance on him to induce them more openly and resolutely to act upon his opinion, and even to call him to power. The effect of this proposition, secret and unflattering as it seemed to be, was exceedingly striking on Mirabeau himself. $\mathrm{H}$ is $\checkmark$ vanity was intensely gratified by this reluctant but spontaneous recognition of his power on the part of 
those who still wore the crown of France; and M. de la Marck observes with reason that, in the early part of the Revolution, notwithstanding the violence of the speeches delivered in the National Assembly against the power of royalty, most of those daring haranguers might have become ardent royalists if the King and his ministers had had the art of drawing them over to their side. In this instance Mirabeau seems to have overlooked, with his natural impetuosity, the doubtful and limited nature of the task confided to him, or rather the utter inadequacy of the means compared with the magnitude of the enterprise. Under this impulse he addressed to the King the paper dated May Io, I 790, which pledged him as strongly as words could do it to the defence of the monarchy.

$\checkmark$ It was at this period that the pecuniary arrangements between Mirabeau and the Court were settled. The Queen had inquired what it would be proper that the King should do for his new adherent. It was proposed that his debts should be paid, amounting to he knew not what; and in addition Mirabeau himself said he should be perfectly satisfied if he could rely on Ioo louis a-month. At length a schedule of his debts was drawn up, some of them ludicrously characteristic of the strange vicissitudes 
of his life-for instance, his wedding clothes were still unpaid for. The whole sum, however, amounted to only 208,000 francs $(8,350 l$.) -no immoderate sum, M. de la Marck observes, for a man who had just come by his father's death into a landed estate of 2,00ol. a-year-if, indeed, that was all; but from Mirabeau's notorious irregularity in all such matters, and his utter indifference to the fate of his creditors, it is more than doubtful what part of his debts this schedule represented, though $M$. de la Marck takes it for granted that nothing remained to be paid. Mirabeau himself still declared that his debts were far too considerable to be paid at all, and that all he could expect was the roo louis a-month. At the next interview which M. de la Marck had with Louis XVI., the King said that the debts should be paid, that Mirabeau should receive 6,000 francs a-month, and he placed in M. de la Marck's hand four notes of hand for 250,000 francs each, making in all one million, which were to be given to Mirabeau at the close of the session of the National Assembly, if he fulfilled his engagements. These bills were never made over to him, and after his death in the following year, M. de la Marck returned them to Louis XVI.

Such acts of munificence threw Mirabeau into a 
state of frantic joyous excitement, and he instantly discovered in Louis XVI. all the qualities of a great sovereign. The first use he made of this turn in his affairs was, regardless of all that could be said by his friends, or was said by his enemies, to set up a luxurious establishment, with cook, coachman, and all the external signs of an expenditure which, as the public well knew, could only be supported by some form of bribery.

The immediate result of this arrangement was the letter addressed by Mirabeau to Louis XVI., dated May IO, I 790, which has been alluded to by several writers as the royalist profession of faith of the great orator, and, indeed, has already been published by M. Barrière ; but the solemnity of its language, and the peculiarity of the engagement thus contracted, entitle it to a place here :-

\section{Count Mirabeau to King Louis XVI.}

Profoundly affected by the sufferings of the King, who has least deserved to feel the pangs of personal misfortune, and persuaded that if there be a prince in such a situation whose word may be trusted, that prince is Louis XVI., I am, nevertheless, so armed by mankind and by events against the touching inpression of all human vicissitudes, that I should feel an invincible repugnance to play a part in this moment of partisanship and confusion if I was not convinced that the restoration of the legitimate authority of the King is the first requisite of France, and the only means to save her. 
But I perceive so clearly that we are in anarchy, and that we are sinking deeper into it every day-I am so indignant at the idea that I should only have contributed to a vast demolitionand the fear of seeing any other head of the State than the King is so intolerable to me, that I feel I am imperiously recalled to public affairs when, wrapped in the silence of contempt, I imagined that I aspired to retirement. Here then is the profession of faith which the King has desired. He will himself deign to name the person in whose hands it shall be deposited, for the dictates of prudence forbid His Majesty to retain it, and this writing will remain for ever as a judgment upon me or a testimony in my favour.

I engage to serve with my whole influence the true interests of the King, and, lest this assertion appear too vague, I declare that I hold a counter-revolution to be as dangerous and criminal as it is chimerical in France to establish a government without a chief armed with the necessary powers to apply the whole public force of the country to execute the law. In these principles I shall communicate my opinion on passing events in writing, and I shall make it my chief business to place the executive power in its proper place in the constitution, which ought to be in its plenitude without restriction or division in the hands of the King. . .

I promise the King loyalty, zeal, activity, energy, and a courage beyond all that has been imputed to me. I promise him all, in short, except success, which never depends on a single man, and which it would be culpable rashness and presumption to promise in the terrible disorder which undermines the State and threatens its chief. He must be a singular man who should be indifferent or unfaithful to the glory of saving both the one and the other, and that man I am not.

The Count de Mirabeau.

In spite of the rhetorical artifices of this letter, which wants the simplicity of truth, and looks like 
a case drawn up for ulterior objects, we do not believe that the intentions expressed in it were deliberately false. It is impossible to doubt that Mirabeau had long since conceived the most gloomy forebodings of the results of the Revolution; and in his furious appeals to the popular party his true sentiments were in reality more disguised than in his secret communications with the Court. The negotiations just completed through M. de la Marck had flattered his vanity, inflated his hopes, and relieved him from his creditors. To inspire confidence in the Court towards the insidious and terrible ally thus enlisted in their service, was obviously the only mode of strengthening and perpetuating his influence. He already aspired to a power more definite and positive than that which he wielded as the tribune of a popular Assembly and the hero of a Club. He despised cordially that Assembly which he fired day after day with eloquence not always in the best taste, or led by arguments which were as $\checkmark$ often sophisms as truths. The remnant of the executive power seemed almost within his grasp, and he flung himself upon it in the general wreck. If $\sqrt{ }$ Totally devoid of principle, he turned with equal indifference to either side, and his interest seemed $\checkmark$ to incline at that moment towards the Court. But 


\section{Lafayette}

MIRABEAU.

that fragment of power was already chiefly held, and might hereafter be successfully disputed, by a man' who up to that time represented more than Mirabeau himself the republican spirit of the Revolution. M. de Lafayette occupied in the streets of Paris, in the National Guard, and in the eyes of the public, the foremost place; Mirabeau had as yet scarcely extended his popular influence beyond the range of his parliamentary eloquence. All France was at the feet of Lafayette. The Revolution was in his hands. The patronage of the Crown was at his disposal. His presumption and his republicanism knew no bounds; and the arrogance with which he treated Mirabeau was equally preposterous. 'I have conquered,' said the tricolor General of the Parisian Guard to M. Frochot-' I have conquered the King of England in his power, the King of France in his authority, the people in its rage ; certainly I shall not yield to M. de Mirabeau.' Yet the struggle and the personal aversion of these two rivals were kept within secret limits ; and Mirabeau, on his $\checkmark$ side, was well aware that Lafayette was a man he either must conciliate by his advances, or paralyse by his attacks. He tried to do both, and, with his usual duplicity, he did both simultaneously. We find in these volumes strange and servile appeals to friend- 
ship and union addressed to Lafayette himself, in which Mirabeau declares that he is more necessary to him than all his other adherents, and that he ought to become the 'dictator of the dictator.'

Ob M. de Lafayette (he continues), Richelieu was Richelieu $\checkmark$ against the nation for the Court, and though Richelieu did infinite harm to public liberty, he did a large amount of good to $\checkmark$ the monarchy. Be Richelieu over the Court and for the nation, and you will reconstitute the monarchy whilst you extend and perpetuate the liberties of your country. But Richelieu had his Capucin Joseph; do you too have your EMINENCE GRISE, or you will ruin yourself without saving us. Your great qualities require my impulse ; my impulse requires your great qualities : and you believe little men, who, for little considerations, by little mancuvres, and for little objects, seek to render us useless to each other : you do not see that you must espouse me and trust me for the very reasons for which your stupid partisans have most abused me. Sir ! you palter with your destiny.

The very same day-June I, I 790-on which this letter was dispatched to the General, Mirabeau addressed his first note to the Queen, expressly intended to cross and annihilate the power of the man to whom he was then offering his services as a second 'Eminence Grise :'-

What is to become (says the same pen on the same day to Marie Antoinette) of that man who has become, from a supple intrigant and a humble courtier, a keeper of kings, if nothing stops him in his career? Master of the Parisian army, and by that army of Paris; master, through Paris, of a great part of the National Guards of the kingdom; able to dispose of the executive power if 
the ministers are chosen by himself; thus, too, of the army-thus, too, of the legislature. If ministers devoted to his ambition refuse him no means of influence, will he not be the most absolute, the most formidable dictator?

Thus at the very same instant Mirabeau presses Lafayette to form a coalition with himself, and presses the Queen to have recourse to himself in order to counteract the influence of Lafayette. If M. de la Marck intended this collection as a posthumous defence of Mirabeau's character, he certainly leaves much undefended; but this single instance of duplicity within the compass of seven pages of the second volume, suffices, in our judgment, to annihilate all trust in any assurance Mirabeau could give either living or dead. The annexed note $\checkmark$ addressed to the Court on June 20 was even more unmeasured in its language and more arrogant in its pretensions :-

It cannot be disguised that the political crisis is at its height, and is alarmingly complicated. I do not think the throne, and still more the dynasty, have ever run a greater danger. It is no longer time to trust by halves, or to serve by halves. There is ample proof that Lafayette is equally ambitious and incapable. He will make himself generalissimo-that is, he will cause the post of generalissimo to be offered him; or in other words he will receive the de facto dictatorship from the nation, or what appears to be the nation. That is his whole scheme for the present. As for a plan, he has none. His means, he picks them up by hand day by day. His whole policy is to excite such a 
fermentation amongst our neighbours that he may be allowed to extend over the whole kingdom the influence of the mob (de la courtille). The only resource against this state of things lies in the imbecility of his mind, the timidity of his character, and the narrowness of his head. The King has but one man, and that is his wife; the only security for her is in the restoration of royal authority. I trust she would not accept life without her crown, but I am certain she will not preserve her life unless she preserve her crown. The day will come, and that soon, when she must try what can be done by a woman and a child on horseback. That is for her a family resource (une méthode de famille); but meanwhile we must be prepared, and not expect to get out of an extraordinary crisis by ordinary men or means. The Queen must speak to Lafayette, in the presence of the King, prepared and resolute, and say to him, 'Your functions entirely absorb your individual faculties, which can only be those of one man, and while you are waiting to be strengthened by a new ministry we shall be lost. We must therefore strengthen you. You have and we have the conviction that, besides his talent, M. de Mirabeau is the only statesman of this country; that no other has his completeness, his courage, his character. It is evident that he will not assist in demolishing us; he must not be driven to that pass; he must be ours. To make him ours we must be his. He wants a grand object-great dangers, great means, a great glory. We $\checkmark$ are resigned or resolved to give him the confidence of despair. I demand that you should unite yourself to M. de Mirabeau completely and entirely, so that we may say, Those two men are ours: whatever is deliberated and agreed upon by them is our will, and that will shall be executed, or we will perish.'

That this rhodomontade should have been seriously addressed to the Queen of France by Mirabeau, and an attempt made to place such expressions as these 
in the mouth of Marie Antoinette by the very man whom they concerned, is certainly one of the most $\checkmark$ daring acts of impertinence and vanity that even the French Revolution has exhibited to the world. But the attempt to bully and terrify the Court overshot its mark; and, on the other hand, all approach to a reconciliation with Lafayette fell to the ground. Shortly afterwards, Mirabeau, in writing to M. de Segur, said that he defied M. de Lafayette to name a single instance in which he had not broken his promises to Mirabeau, or in which Mirabeau had not kept his promises to Lafayette. Before October of the same year their relations had settled into permanent aversion and resentment, and Lafayette is only mentioned in this correspondence under the contemptuous nicknames of Gilles le Grand, JupiterScapin, or the like. The Queen, however, did not express her disapprobation of the tone of the extraordinary communication just cited ; and it was a few days after she had read that paper-on July 3-that a secret interview took place-the first and lastbetween Mirabeau and Marie Antoinette in the upper part of the gardens of St. Cloud. The Queen accosted him (as she afterwards informed Madame Campan) by saying that, " in presence of an ordinary enemy, a man who had sworn the ruin of the 
monarchy without perceiving its utility to a great people, the step I am now taking would be extremely out of place; but when I speak to a Mirabeau,' \&c. Mirabeau quitted the Queen with the exclamation 'Madame, la monarchie est sauvée!' But, in spite of the apparent intimacy which the relations of Mirabeau with the Court had at this time acquired, and the vehement frankness with which he addressed the illustrious personages to whom these notes were transmitted, there is no indication that the conduct of either party was sincere. Mirabeau, in the receipt of a large pension paid at short intervals, and in the hope of acquiring more positive power by the overthrow of the ministry and the destruction of his rivals, was probably in earnest; but from first to last it would seem that his remonstrances and suggestions remained without effect; his advice had been asked, as an indirect method of paralysing his hostility in the Assembly, but it was never taken ; and from time to time his indignation was roused by the discovery that some agent of very inferior judgment and powers, like M. Beigasse, had contrived to guide that perplexed and irresolute côterie in the palace which all his eloquence and his reasoning failed to move.

$\checkmark \quad$ In the position which Louis XVI. had then 
reached, it is impossible to deny that the policy steadily advocated by Mirabeau was infinitely preferable to the feeble palliatives of the existing ministry, who were drifting down the torrent, or to the abortive projects of flight and reaction put forward by the remains of the aristocratic party. Mirabeau strenuously advocated the formation of a nucleus of troops in some available part of France, either at Fontainebleau or at Rouen, sufficiently near the capital to take away the appearance of flight, sufficiently remote from Paris to restore the sovereign and the royal family to their personal independence. Disorganised as the army was, it was still possible to rely on the fidelity of a few regiments animated by the spirit of their officers, and Mirabeau had already observed the valour and discipline of the Swiss Guards, which were afterwards to be vainly expended in the last fatal struggle of August Io. $\mathrm{He}$ proposed to revive the office of 'InspectorGeneral of the Swiss troops,' and to entrust that post to Count de la Marck himself, as an officer of unquestionable fidelity and ability. Alone, amongst all the advisers of the Court who professed any tinge of liberal principles, Mirabeau boldly avowed that he did not recoil from the prospect of civil war, since he regarded it as an evil of far less magnitude voL. I. 
than the rule of mobs and the triumph of anarchy, and he foresaw that nothing but the regular action of military power could restore the authority of the crown. But he ardently, and, in this instance, successfully, resisted the peril of foreign war, and especially of war with England, when Spain, on the prospect of hostilities with reference to the Nootka Sound dispute, claimed the execution of the Family Compact. The appeal to foreign succour against the internal dangers of the royal family and the monarchy, which so greatly aggravated those dangers on the outbreak of the war, and became the heaviest of the charges against the Court, never entered into the plans disclosed by this correspondence : for it is worthy of remark that, although, throughout this transaction, M. de Mercy, the Austrian ambassador in Paris, and M. de la Marck, an Austrian by birth, were the principal agents of the Court, they uniformly and exclusively acted as Frenchmen should have acted, and in defence of purely French interests. If ever there was an 'Austrian Committee,' as it was termed, in the closet of Marie Antoinette, it was in I 789 and I790, and it was composed of these two men. Long before the pretended disclosures of the Iron Chest, it had ceased to exist altogether, for both of them had left France. The negotiations 
with the German Powers which were conducted by M. de Mercy, began at a later period, and Mirabeau had certainly no part in them. During the period of his greatest activity not a line is to be found which the most captious partisan could construe into an encroachment on the independence of the French nation. Mirabeau's uniform recommendation to the King was to endeavour to prepare some military resources and some degree of popular support out of Paris and in the country: to retire, then, from the capital with his face towards the enemy; to form a government on national and liberal principles; to complete the constitution, but to put an end to the Revolution, and to stake everything on the success of a scheme which, though hazardous, was better than to perish bit by bit by the slow pressure of necessity, or to descend by slow degrees into that abyss whose depth at that moment Mirabeau had already sounded. The King distinctly intimated, at a still later period, that he regarded these statements as much exaggerated. The sagacity of this advice, and the force of reasoning with which it was supported, in spite of the blemish of occasional violence and exaggeration of language, considerably raise our estimate of Mirabeau's political judgment. There is, we believe, no doubt that these 
papers were entirely written by himself. The drafts in his own handwriting exist at this moment in the archives of the House of Arenberg at Brussels, and may be seen there. The preparatory labours of his Genevese aides de camp for his speeches on questions of general interest in the National Assembly were of a different character, and it seems that none of these persons were cognizant of the extent of his relations with the Court. These writings, on the contrary, bear the stamp of his own genius-of his ardent resolution-and not unfrequently of his irritation at the manifest failure of all his proposals. For it is not the least curious part of this correspondence, continued during a period of ten months, that it was invariably and completely sterile, except, perhaps by the indirect influence it had on the public conduct of Mirabeau in the Assembly, where he might, and doubtless would, have become more bitterly hostile if he had been thrown altogether and exclusively on his revolutionary associates. Yet Mirabeau could not but perceive-what a man of more delicacy and less vanity would have detected sooner-that not one of his proposals took effect, and that he was kept in the King's pay not for the advice he gave, but because he gave it. On September 20 he wrote to M. de la Marck :-

The reason we do not get on is not my occupations, absorbing 
as they have been for the last ten days, but the strange conduct of the Court towards me. It never profits by one of my counsels, and then calls me unprofitable. It is for ever aggrandising its enemy, without giving me any consecutive means of action or habitual instructions, and then affects to suppose this enemy is to be vanquished by me. This is pitiable.

And again more bitterly a month later :-

I hardly know, my dear Count, why I send you these notes; but take them for what they are worth-here is another. These subjects for comparison with the masterpieces of Bergasse, and perhaps of Barnave and other great men, to whose hair, as of old to that of ancient Nisus, the safety of the throne and of the empire are doubtless bound ; these subjects for comparison are a mode of study not duller than a prison or more useless than a fairy tale. Vale et me ama.

But the 6,000 francs a month kept him employed, and he exhaled his resentment in undoing his own work elsewhere. At that price success was an object of secondary importance.

M. de la Marck himself, who shows an unreserved confidence in Mirabeau in all that has been preserved of their direct correspondence, did occasionally indicate some alarm and distrust, arising out of this state of things, in the reports he subsequently addressed to Count de Mercy, after that envoy had been withdrawn by the Imperial Government from Paris. Thus, he observes on the 26th of January 
M. de Mirabeau is seeking to conciliate an apparent wish to serve with inaction, to drive others forward and to hold back himself, to have the merit of success without exposing his popularity to too severe a trial. We must not deceive ourselves; this man finds in his talents, in his mistrust, and even in his faults, subterfuges of dexterity by which he frequently escapes the nicest observation.

M. de Mirabeau has been elected chef de bataillon ${ }^{1}$ (of the National Guard), and three days later a member of the administration of the department. He has accepted both these places, meaning subsequently to resign the former. He is now trying to be elected procureur syndic of the department. His popularity has really increased of late, which makes me uneasy: if ever he despairs of the Government and stakes his fame on his popularity, he will be insatiable: and you know as well as I do, Monsieur le Comte, what popularity is in a time of revolution.

\section{Such was the lame and unsatisfactory course of a} negotiation which Mirabeau himself described in the

1 This election to the rank of officer in the National Guard gave rise to one of the strangest communications of Mirabeau to the Court, for the National Guards were at that time the keepers, and almost the jailers of the Tuileries, the officer on duty keeping the royal family in constant surveillance. Mirabeau affected to ask the Queen's permission to accept the post, insinuating that, while he was playing ninepins with the Dauphin, or picking up his ball, he should have ample opportunities of conversing with his Sovereign.

But, in fact, Mirabeau was always eager to be elected to everything. He was indignant when Bailly was chosen mayor of Paris in preference to himself; he continually aimed at the presidency of the Assemblyhe intimated to Lafayette his readiness to accept an embassy to the East-he acted in the National Guard when named chef de bataillonand probably would not have refused, on the first vacancy, to be sexton of the parish. 
most complete and elaborate of these documents to be a system of 'obscure intrigue and artful dissimulation ;' for he who had shown himself most powerful to agitate and to destroy, proved himself powerless to save, and many of the provisions on which he affected to rely for the safety of the Court and the preservation of the monarchy were puerile and impracticable.

The only feasible measure to which the Court brought itself to assent, was a journey undertaken by M. de la Marck himself to Metz and Strasburg in February I79I, for the purpose of saving M. de Bouillé and the army on the eastern frontier of the kingdom, which was in truth the last hope of the monarchy. It is probable that the reports addressed by M. de la Marck to the King and Queen on his return to Paris, strengthened the intention of flight which was afterwards executed, but interrupted at Varennes, when all other hopes had failed. Mesdames, the King's aunts, actually attempted to make their escape on the rgth of February, contrary to the advice of Mirabeau, and were arrested at Douay-le-Duc in Burgundy. When the news of this incident arrived, La Marck had been sitting up all night drinking, and forwarded the intelligence to Mirabeau, with an intimation that his own faculties were not perfectly clear. But the 
question having been discussed in the Assembly, Mirabeau obtained a vote in favour of the Princesses, who were consequently allowed to depart. On this occasion La Marck observes, in writing to M. de Mercy,

... the determination of Mesdames to start has proved that if the King followed their example he would probably have the same success. He should only announce positively beforehand that he means to go out of Paris, fix the day of his departure, and persist with energy in his resolution. Il faudrait bien qu'on le laissât faire.

Yet, as it turned out a few days afterwards, a mere excursion of the Court to St. Cloud caused a riot in Paris; and indeed in the very same letter he speaks of M. de Lafayette's resolution ' to keep his prisoner,' for the King was the hostage of the monarchy held by the mob of the capital.

Such was the state of affairs, with no definite plan and no prospect of a more vigorous course of action, when the man, who was the centre of these intrigues, was suddenly struck in mid career by the abrupt summons of a mortal and rapid disease. In the last week during which Mirabeau attended the sittings of the National Assembly, a question was under discussion relating to the rights of mineral proprietors and mining property in France, which was of the utmost importance to Count de la Marck, 
who had a large portion of his private fortune in these investments. The Assembly seemed disposed to prohibit grants of mining leases. Mirabeau said to his friend-' If I do not defend sound principles in this matter, there will be an end of mining in France, and you will lose one of the chief parts of your fortune. If I do defend them, I shall crush our antagonists.' He spoke with effect on the 2 Ist of March on this subject, his speech having been prepared by Pellene, one of his secretaries. The question was to come on again on the 27 th, and though already ill he set to work again to produce the harangue that was to gain the victory.

On the morning of that day, says M. de la Marck, he came to my house before nine in the morning. His countenance was haggard, and he looked like a man on the eve of a serious illness. $\mathrm{He}$ got worse, and even at one time lost his consciousness. I did all I could to prevent him from going to the Assembly, but without success. $\mathrm{He}$ continually answered, 'My friend, those fellows will ruin you if I don't go : I will go; you shall not keep me.' Feeling himself too weak to walk, he remembered I had some old Tokay, which he had drunk of several times. He rang and himself ordered some to be brought him. He took a couple of glasses, and got into his carriage. I wished to accompany him, but he insisted I should not go that day to the Assembly. He begged me to wait at home till he came back to me. I was obliged to yield. About three o'clock he returned. As he came into my room, he flung himself upon a sofa and said, 'Your cause is gained, and I am a dead man.' I cannot express what I felt at the moment, struck with terror as I was by the state of 
Mirabeau. In a few minutes I gave him my arm-led him to the carriage, got in with him, and drove to his house, which he never left more till he was carried to the grave.

The disease, which had on several former occasions threatened the life of Mirabeau and preyed upon his shattered constitution, now declared itself with extreme violence. From the first Cabanis, who attended him, entertained no hope, and Mirabeau himself seemed, from the expressions he made use of to his friends, to be fully prepared for the worst. M. de la Marck was constantly with him, and it was on the fourth day of his illness and the third before his death that he confided to him the whole collection of his papers, at that time of such momentous importance to the chief persons in the state, and subsequently so essential to a correct understanding of his policy and conduct. On the 2nd of April I 79I, at half-past eight in the morning, after a long and painful struggle, Mirabeau expired, at the age of forty-two. His loss was mourned by $\checkmark$ the people, whom he had alternately excited and misled, as a national calamity, and it was said that upwards of 200,000 persons escorted his remains to the Pantheon. Certain it is that of all the men, not deficient in numbers, in power, or in eloquence, whom the earlier months of the Revolution had 
thrown before the world, Mirabeau alone seemed qualified to stride onwards in its rapid and terrible course. He had the good fortune to die before his popularity with the Assembly had undergone the test of ministerial power, and before the services he had proffered to the Court had heen actively or practically employed. He left, therefore, to both parties a sense of his vast abilities, augmented by the vague hopes which are apt to be excited by a career of unfulfilled renown. To the popular cause $\checkmark$ it seemed, in the anarchy which speedily ensued, that nothing was wanting but that daring leader; to the Court, that the Revolution might still have been arrested by the counsels of such a servant. The character of Mirabeau, judged by his public acts, assisted by the strong light thrown on his private motives by this publication, justifies, in our opinion, no such favourable inference on either side. In the clubs and assemblies of the people there is ample evidence that he was playing a game widely distinct from his genuine opinions or his secret desires : in his relations with the Court he was met at every turn by the distrust which his own virulent language could not fail to inspire. But the real incentive $V$ was neither patriotism nor loyalty; it centred altogether in his own personal interests; and his 
conduct was turned either to the right or to the left by the merest caprice or by the basest impulses of resentment.

$\checkmark$ With such objects and such means of action we can discover no evidence in support of the common but conjectural belief, that if the life of Mirabeau had been prolonged it would have fared otherwise with the French Revolution, and that even the monarchy might by his hands have been saved. On the contrary, all the services it was in his power to have rendered to the Court might have been rendered, and indeed were rendered, in the course of the twelve months preceding his death; and there is no ground to assume that his efficiency, the confidence of his employers, or the opportune conjunction of events would at any time have become greater or more favourable than they had been in that period. $\checkmark$ Having failed at that time, he would have succeeded at no other; and though he might have prevented some disastrous mistakes, such as the flight to Varennes and the return of the Royal Family, it was already beyond his power to arrest the ravages of a monster he himself had invoked upon his country. In these respects the Correspondence now before us changes none of the previous conceptions of his charac$\checkmark$ ter : it leaves him in possession of the doubtful honour 
of genius fruitful only in destruction, and of dishonesty marking even his better actions as if they were crimes. On one point only it improves the aspect of his character by the warmth and apparent sincerity of several of his personal friendships, and especially of that which he entertained for Count de la Marck himself : but even that redeeming quality was weakened by the practices to which his dearest acquaintances were certainly exposed and by the selfish colour even of his familiar friendships. $\mathrm{He}$ left behind him the reputation of unrivalled eloquence, of daring worthy of a nobler cause, of a judicious sagacity in the discussion of many of the chief political questions of the day, and even of $a \vee$ desire to quench the conflagration he had kindled. But it was too late; the effort was beyond the $v$ control of any mortal power; and had he lived, he would have lived only to perish, like all his political confederates, in the fierce anarchy which avenged the Revolution on its authors. 

MARIE ANTOINETTE. 



\section{MARIE ANTOINETTE. ${ }^{1}$}

IF the authenticity of these several collections of letters of the last Queen of France and of her nearest connections could be irrefragably established, we should without hesitation assign to them the highest place among the innumerable memorials of the French Revolution. They bring Marie Antoinette before us in the freshness of her girlish royalty, when she passed, at fifteen, from the domestic circles of Schönbrun and Laxenburg to the depraved Court of Louis XV. and the pestilent intrigues of Versailles. They follow her through the earlier years of her reign, when the refinement of her tastes and the vivacity of her affections were

1 This paper was first published in the Edinburgh Review, No. 252, for April I 866. The books under review were as follows :-

I. Maria Theresia und Marie Antoinette, ihr Briefwechsel während der Fahre 1770-1780, herausgegeben von Alfred Ritter von Arneth. Paris und Wien : 1865. 2. Correspondance inédite de Marie-Antoinette. Publiée sur les documents originaux par le Comte Paul Vogt d'Hunolstein. Troisième édition. Paris : 1864. 3. Louis XVI, Marie-Antoinette, et Madame Élisabeth. Lettres et documents inédits publiés par F. Feuillet de Conches. (Second tirage.) Trois tomes. Paris : 1864 .

VOL. I. 
struggling with the severe exigencies of her actual position and the dark harbingers of her tremendous destiny. They contain, lastly, a large addition to the evidence already in our possession of her courage and contrivance-her noble bearing and her devoted energy in defence of those she loved when the ranks of her enemies were closing around her, and the realm over which she had reigned was narrowed to the miserable turret of the Temple and the dungeon of the Conciergerie. These letters illustrate, in the most remarkable manner, her qualities and her defects, her virtues and her faults, her strength of purpose and her errors of judgment. We rise from a careful and repeated perusal of them with the conviction that the whole character of the Queen is now before us, and not only of the Queen, but of her husband, her sister, and her nearest friends. The stately figure of Maria Theresa ushers in the group, not without impressive warnings of the impending tragedy; and the humorous scepticism and shrewd sense of Joseph II. complete the singular picture. So much, at least, of these letters is beyond all question true and authentic, that the omission of all the suspected documents would not materially alter or injure the general effect of the correspondence; and we regret 
that publications of such deep historic interest should require at our hands in the first instance the investigation of a charge of literary forgery. Such, however, is the case. Soon after the appearance of M. d'Hunolstein's and M. Feuillet de Conches' collections in Paris, another volume was published by Ritter von Arneth in Vienna, extracted from the archives of the Imperial family; and a comparison between these different versions of the correspondence between Marie Antoinette and her mother, which has been set on foot, and conducted with great ingenuity by M. von Sybel, an eminent German critic, has led him to impeach the authenticity of the earlier papers produced by the French editors, and consequently to throw a shade of suspicion over the whole of their work.

To put the reader in possession of the elements of this controversy, we must, first, briefly describe the nature and pretensions of the three collections : and we begin with that of Ritter von Arneth, because its genuineness being indisputable, it has been applied as the text or canon to determine the genuineness of documents found elsewhere. The following is the Vienna editor's account of his materials :- 
The correspondence of Maria Theresa and her daughter which is here published is at this moment, and, most probably, always has been, preserved in the private library of the head of the Imperial family. The volume which contains it is inscribed, ' I 770-I 780. Correspondance de S. M. l'Impératrice-Reine avec la Reine de France.' The whole collection consists of ninety-three letters of Marie Antoinette to her mother, of which thirty-seven are the originals; the remainder are copies, which were evidently made to the order of Maria Theresa, by her confidential cabinet secretary, Charles Joseph Baron von Pichler, in his own handwriting. Several of Marie Antoinette's letters exist, both in the original and, at the same time, in Pichler's well-known handwriting. These are, therefore, the best proofs of the conscientious diligence with which Pichler performed his task. The seventy answers of Maria Theresa exist, as might be inferred from the nature of the case, only in copies made by Pichler. It may be inferred from one of Marie Antoinette's own letters (that of July $\mathrm{I} 2, \mathrm{I} 770$ ) that the originals were probably destroyed by her to whom they were addressed.

It is contended that these letters form but a part of the correspondence between mother and daughter in ten years of separation; and one of the mysteries in this inquiry is, why these particular letters were preserved so carefully, when others have disappeared. However, such as they are, the Vienna letters have now been published with scrupulous fidelity by M. von Arneth; and he has added to his volume photographs from four of them, as specimens of the Queen's handwriting at different periods. Here, then, we have a certain number of 
documents of unquestionable authenticity. The custody in which they have been preserved is that .of the august family to whose head they were addressed. The gilt-edged paper on which they are written is that which the Queen was known to use. The handwriting of the first letter in July 1770 is that of a child hardly able to form her letters, and confirms Madame Campan's statement that when Marie Antoinette arrived in France they had to assist her imperfect penmanship, so wretchedly had her education been neglected. In two or three years her hand improved and gradually formed itself. Lastly, the confidential and intimate tone of the letters is precisely what might have been expected to pass between the writers. This, then, is an undoubted portion of the correspondence in question ; but, strange to say, although M. d'Hunolstein publishes forty-five and M. Feuillet de Conches twenty-one letters of the same period, alleged to have been exchanged between the Empress-Queen and her daughter, only one of them is identical with those which exist at Vienna, many of them are essentially different, and some of them are contradictory and incompatible, not only in point of dates, but in substance.

The courier of the Imperial Embassy, by whom 
Marie Antoinette sent her letters, started from Vienna about the beginning of every month, and from Versailles on his return about the 15 th; and as he generally carried a private letter from each sovereign, about twelve letters must have been sent every year on each side. In the space of nearly ten years this would amount to 240 letters. Only I 53 are published by M. von Arneth, but with some allowance for occasional interruptions, omissions, or losses, this is not very far below the estimated number. In the earlier years the correspondence was less frequent and regular. In 1778 no less than thirty letters were exchanged, owing to two peculiar occurrences in the spring of that yearthe disputes on the Bavarian succession and the first pregnancy of the Queen. These circumstances led to an increase in the number of couriers, which did not take place on any other occasion. But the incredible part of the story is that while this correspondence was going on at regular intervals-the Empress always writing at the beginning of the month, and the Queen always answering in the middle of the month-another series of letters should have passed at irregular dates, wholly unnoticed in the authentic correspondence. In M. d'Hunolstein's volume many of the Queen's letters are dated 
early in the month, - a time at which she appears never to have written, as her letter would then have crossed her mother's letter on the road.

The volume for which M. d'Hunolstein is respon. sible has been ushered into the world without any pretension to editorial care. That gentleman contents himself with informing his readers that all the documents comprised in it have been copied from and collated with the originals-that some of these letters had appeared elsewhere, because the Queen was in the habit of making drafts and keeping copies of her correspondence-but that all the letters now published by him are printed from bonâ-fide originals collected by himself. It does not seem to have occurred to M. d'Hunolstein that to establish the authenticity of these originals something more is needed than the mere inspection of them by a few 'serious amateurs.' Where did they come from? How came it to pass that letters addressed for the most part to the near relations of the Queen at Vienna and in other parts of Europe, should nevertheless have been removed from the depositories where they would naturally be preserved, and offered for sale in Paris? We know indeed that in 1809 Napoleon obtained at Vienna copies of some of the remarkable letters 
written by Marie Antoinette to her brother, the Emperor Leopold, in I79I, which he brought to Paris, and which were published in 1835 in the 'Revue rétrospective.' But the cession of these precious documents was an affair of state. Nevertheless, M. d'Hunolstein boasts that he is the possessor of the originals of some of these same papers, and has republished them in this volume. The mere fact that several autograph copies exist of a very lengthy and confidential document throws suspicion on it. The improbability that such a paper would be repeatedly copied by the writer, when the discovery of a single copy might have cost a life, is extreme. Every collector of autographs knows that without extrinsic evidence no absolute reliance can be placed on the apparent identity of handwriting. But in this case the extrinsic evidence is against the authenticity of $\mathrm{M}$. d'Hunolstein's collection. ${ }^{1}$

1 It is the more remarkable that so many of the private papers of Marie Antoinette should recently have turned up in Paris, as Madame Campan expressly states that they were burnt immediately after July 14, I792. 'La crainte d'une nouvelle invasion des Tuileries fit faire les recherches les plus exactes dans les papiers du Roi ; je brülai presque tous ceux de la Reine. Elle mit dans un portefeuille, qu'elle confia à Monsieur de J., ses lettres de famille, etc., et ses réponses dont elle avait fait des copies. M. de J. n'a pu conserver ce dépôt; il a été brûlé.' (Mémoires de Madame de Campan, vol. ii. p. 207.) Supposing however, that Madame Campan was mistaken in this last particular, 
These adverse facts have been collected with much ingenuity, but far too much acrimony, by $\mathrm{M}$. von Sybel, the editor of the "Historische Zeitschrift" of Munich. He pointed out that the style of the series of letters to Maria Theresa published by M. von Arneth is simple, dry, childish, and natural, that of her letters in the French editions far more elaborate, sentimental, and artificial; that no new facts are adverted to in the French collections which were not already known by Madame Campan's Memoirs or the Gazette of Paris ; that the Dauphiness always signs her letters 'Antoinette' in the Austrian series, and always 'Marie Antoinette' in the French series ; that, with reference to the letters said to be addressed by the Queen to her sister Marie Christine, Duchess of Saxe-Teschen, whom she calls her dearest friend, there was, in fact, no such intimacy between them; the Archduchess was thirteen years older than the Queen, that is, almost twice her age at the time of her marriage, and Marie Antoinette was in the nursery when Marie Christine left Vienna. It appears, moreover, that the papers of this lady and that this 'dépôt' had not been burnt, that would explain the possibility of the discovery of the papers. We hear that some of these documents have been procured from a person formerly in Madame Campan's employment. On the other hand, the statement that these papers did exist, and were confided to her, may have encouraged persons to supply by forgery the lost originals. 
and her husband the Duke Albert (with his diary) have been carefully preserved, and that they contain no allusion to any intimate correspondence with the Queen of France. Upon an actual inspection of the Hunolstein letters by M. Sybel, these suspicions were augmented. All the Austrian letters are on gilt-edged paper-all the French letters are plain. The writing of the former varies considerably with the advancing years of the young Princess-that of the latter is uniform.

To these and many other similar considerations must be added some remarkable inconsistencies in the two correspondences supposed to be simultaneous. For instance: in the very first authentic letter of Marie Antoinette to her mother (July 9, I 770, Arneth Collection) she says :-

Le Roi a mille bontés pour moi, et je l'aime tendrement; mais c'est à faire pitié la faiblesse qu'il a pour Madame du Barry, qui est la plus sotte et impertinente créature qui soit imaginable. Elle a joué tous les soirs avec nous à Marly; elle s'est trouvée deux fois à côté de moi, mais elle ne m'a point parlé, et je n'ai point tâché justement de lier conversation avec elle ; mais, quand il le fallait, je lui ai pourtant parlé.

In several of the letters of Maria Theresa, that - politic princess, whose moral dignity did not stand in the way of her interest, recommended her daughter to beware of affronting the King's favourite, who 
was notoriously the bitterest enemy of the Duc de Choiseul's party, and to conceal her abhorrence of so contemptible and profligate a personage. More than once the Empress reverts to this subject with great severity, and scolds her daughter (the word is not too strong) for not having spoken to the $\mathrm{Du}$ Barry with sufficient politeness. 'Vous ne devez connaître ni voir la Barry d'un autre œil que d'être une dame admise à la Cour et à la société du Roi. Vous êtes la première sujette de lui, vous lui devez obéissance et soumission; vous devez être l'exemple de la Cour aux courtisans, que les volontés de votre maître s'exécutent.' Marie Antoinette received these remonstrances with spirit, and did not disguise her distaste at the part she was told to play. 'Vous pouvez bien croire,' she replied, 'que je sacrifie toujours mes préjugés et mes répugnances, tant qu'on me proposera rien d'affiché et contre l'honneur. .. . Je puis bien vous assurer que quoique je vous ai montré vivement ma sensibilité, ce n'était que de la sensibilité : on me laisse assez tranquille sur cet article, les amies et amis de cette créature n'ont pas à se plaindre que je les traite mal.' The subject, in short, recurs continually in the letters of both mother and daughter, and it was one on which they evidently both felt strongly, though in a very 
different manner; and it must be admitted that Marie Antoinette, young as she was, had a truer sense of her own dignity than her experienced parent.

Nothing, however, of all this appears in any of the letters of the French editors; but, on the contrary, in a letter from the Dauphiness to her mother, of December 7, I 77I, published by M. Feuillet de Conches, the following passage occurs :-

Reste Madame du Barry, dont je ne vous ai jamais reparlé. ${ }^{1}$ Je me suis tenue, devant la foiblesse, avec toute la réserve que vous m'aviez recommandée. On m'a fait souper avec elle, et elle a pris avec moi un ton demi-respectueux et embarrassé et demiprotecteur. Je ne me départirai pas de vos conseils, dont je n'ai pas même parlé à $M$. le Dauphin, qui ne peut la souffrir, mais n'en marque rien par respect pour le Roi. Elle a une cour assidue, les ambassadeurs y vont, et toute personne de distinction demande à être présentée. On fait foule comme chez une princesse : elle fait cercle, on se précipite, et elle dit son petit mot à chacun. Elle règne. Il pleut dans le moment où je vous écris : c'est probablement qu'elle l'aura permis.

It is evident that the tone and statements of the Vienna letters (which are certainly authentic) on this subject, are totally at variance with the language of the letters in the French collections, and the passage just quoted may serve as a specimen of the epigram-

1 It was parle in the first edition, but that was a misprint. 
matic turn of the French letters, which is amusing enough, but very unlike the style of a girl of sixteen writing to her mother on a matter of so much delicacy and difficulty.

We proceed to another example of these inconsistencies. M. d'Hunolstein publishes eight letters from Marie Antoinette to her mother dated between April 30 and May I8, I 774. The death of Louis XV. took place on May Io, and was of course followed by the immediate accession of his grandson to the throne. These letters, therefore, describe the progress of the King's illness, and its fatal termination. At the moment of assuming the crown, the following letter is attributed to the youthful Queen by both the French editors ; for, oddly enough, each of them has a copy of this document in the Queen's own handwriting - that belonging to M. d'Hunolstein we have not seen, but we presume that it purports to be the original-that of M. Feuillet de Conches (which we have ourselves examined) is a draft with corrections in the same hand. This draft formed part of the papers of the Abbé de Vermond, the Queen's reader. It runs thus :-

Madame et Très-CHère MÈre,-Que Dieu veille sur vous! Le Roi a cessé d'exister dans le milieu du jour. Depuis la matinée du 8, son état n'avait fait qu'empirer, et il a demandé 
l'extrême onction, qu'il a reçue dans des sentiments de piété admirables. Il avait conservé toute sa connaissance et sa présence d'esprit pendant toute sa maladie, avec un courage inouï. Mon Dieu! qu'allons-nous devenir? Monsieur le Dauphin et moi, nous sommes épouvantés de régner si jeunes. $\mathrm{O}$ ma bonne mère, ne ménagez pas vos conseils à vos malheureux enfants.

The sentimental tone of this composition first awakened our own suspicions as to the authenticity of the French correspondence. This is the language of the drama or of romance-not at all the simple matter-of-fact language of Marie Antoinette, who, in her own undoubted letters, never aims at any effects of style, and was, indeed, at that time incapable of producing them. It is true that, admitting the letter not to be the production of the Queen, the draft, which we have carefully examined, and which bears all the external signs of genuineness, might have been prepared by the Abbé de Vermond and never used. In discussing the letters of royal and em:nent persons, it must be borne in mind that a considerable portion of the correspondence written in their names is not their own at all, but is the work of a confidential secretary, who frequently acquires, by habit and imitation, an undistinguishable similarity or identity of handwriting. This officer was known at the Court of Versailles by the title of the Secretaire de la Main. ' Avoir la plume,' says St.-Simon, 
' c'est être faussaire public, et faire par charge ce qui coûterait la vie à un autre. Cet exercice consiste à imiter si exactement l'écriture du roi qu'elle ne se puisse distinguer de celle que la plume contrefait.' President Rose, to whom the foregoing observation is applied) filled this office to Louis XIV. for fifty years, the Abbé de Vermond appears to have stood in very nearly the same confidential relation to Marie Antoinette. He had been recommended by M. de Brienne, then Archbishop of Toulouse, to be her preceptor at Vienna, and he was chosen by M. de Choiseul, at the time of her marriage, to form part of her escort into France. He never left her ; he appears to have lived in her presence, and to have been employed in all the little transactions of daily life-a silent, humble, scarcely perceived, but everpresent friend. He took no part in politics; he mixed in no court intrigues; and if he did no great good, he had at least the merit of doing no harm. Madame Campan, who probably disliked this little Abbé with a jalousie de métier, complains that he gave himself airs. But this is an exaggeration : the long continuance of his services is the best proof of his inoffensive disposition. Yet Louis XVI. disliked him. Vermond was the man of Choiseul, the creature and representative of the Austrian alliance. 
He was allowed to remain in the Queen's apartment like a piece of furniture she might have brought with her from Vienna; but for eighteen years, though the King probably saw him daily, his Majesty never addressed a word of civility to him, or indeed took any notice of his presence. It was not till I 788 , at the time of the affair of the necklace, when the Abbé had executed with address a delicate and important negotiation, that the King once said to him, on leaving the room, 'You have done the Queen a service; sir, I thank you.' But the devotion of the Abbé to his royal mistress stopped short on this side of martyrdom, and it gives one a low impression of his courage to know that he took an early opportunity of escaping to Brussels in the first flight of the emigration. In several of the Queen's letters to M. de Mercy she inquires for the Abbé with great interest. It is admitted on all hands that the Abbé de Vermond did actually write a great many of the Queen's letters, as it was his business to do. Marie Antoinette at fifteen was wholly incapable of composing, or even of copying in a legible hand, the formal and complimentary letters to different persons which figure in these volumes. In February I77I, her mother says to her: 'I can't help observing that the handwriting of your letters is daily worse 
and more incorrect. You ought to have improved in the last ten months. I was ashamed to see the letters you have written to several ladies handed about. You ought to write exercises with the Abbé or some one else to form your hand, to make it more even.' The photographs of the first letters in M. von Arneth's volume establish this fact, and we may infer from it that at the time of which we are now speaking, the Abbe had a large share in the correspondence. This circumstance opens the door to fresh uncertainty, for no one can tell with precision where the Queen begins and the Abbé ends; and it may very well have happened that drafts prepared by the Abbé were never used or sent by the Queen at all.

But to return to the letter of the roth of May, in which the young Queen is represented to have conveyed the news of the death of Louis XV. in this tragical and hyperbolical language The truth is, that a letter exists in the Vienna collection of the r $4_{\text {th }}$ of May, the date of the usual courier in the middle of the month, which begins in the following simple and matter-of-fact sentences :-

Madame ma très-Chère Mère,- Mercy [the Austrian ambassador] will have informed you of the circumstances of our misfortune. Happily this cruel malady left the King in possession

VOL. I. 
of his faculties to the last moment, and his end was very edifying. The new King seems to have the heart of his people : two days before his grandfather's death he caused 200,000 francs to be distributed to the poor, which produced a great effect. Since the demise he works incessantly, and answers, with his own hand, the Ministers whom he cannot yet receive, and many other people. What is certain is that he has a taste for economy, and the greatest desire to make his subjects happy. In all things he has the desire as much as the need of instructing himself. I hope God will bless his good intentions. The public anticipated many immediate changes ; the King has contented himself with sending 'the creature' to a convent, and banishing from court all that bears that name of scandal. (Von Arneth's Collection, p. 98.)

The letter goes on to speak at some length on indifferent subjects - the disgrace of a young Esterhazy - the illness of the late King's daughters, who had taken the small-pox while attending their father's death-bed-the new appointments in the Queen's household, \&c. It then concludes thus :-

Though God caused me to be born in the rank I now occupy, I cannot but admire the order of His providence, which has selected me-me, the last of your children, for the finest realm in Europe. I feel more than ever what I owe to the tenderness of my august mother, who took so much pains and care to procure for me this great establishment. I never so strongly desired to place myself at her feet, to embrace her, to pour out my soul before her, and to show her how filled I am with respect, affection, and gratitude.

P.S.-The Abbé is at your feet [we suspect there is a touch of his pen in the last sentence]; he is as full of respect and gratitude for your goodness as of attachment to me. 
Here follow a few lines in the King's writing :-

I am very glad to find an opportunity, ma chère Maman, to prove to you my tenderness and attachment. I wish I could have your advice in these moments, which are so embarrassing. I should be charmed to satisfy you, and so to show all the attachment and gratitude I feel to you for giving me your daughter, with whom I am as pleased as it is possible.

Marie Antoinette seems to have felt that this little paragraph was not worthy of the occasion, and adds :-

The King would not let my letter go without adding his scrap. I feel that he would have done no more than is proper if he had written a letter on purpose. I entreat my dear Mamma to excuse him, as he has so many things on his hands, which occupy him, besides being naturally timid and shy. You see, dear Mamma, by the end of his compliment, that though he is very fond of me, he does not spoil me by saying sweet things.

This letter strikes us as very interesting, and if we cast a glance onwards to the close of the reign which had just commenced, its simplicity and homeliness are touching. It bears the stamp of reality. There is not a trace of affectation about it. The ' $\mathrm{O}$ ma bonne mère!' of the French editors becomes simply 'ma chère maman'; and between the two compositions there is just the difference which exists between the language of a person of high breeding in a great position and the language of a vulgar person endeavouring to act up to a great part. The 
King's 'scrap,' and the postscript in which the Queen makes the best excuse she can for the bluntness and brevity of her husband, are perfectly characteristic. We seem to see the writers of that page before us. The contrast between this plain letter and the romantic cry of the 'malheureux enfans' called to 'régner si jeunes' is complete; and the undoubted genuineness of the letter of the I 4 th seems to us to deprive of all credit the pretended letter of the Ioth of May.

A formal autograph letter was addressed by Louis XVI. to Maria Theresa on the 5 th of June, to notify his accession to the throne. It still exists in the Imperial Library of Vienna, and is published by $\mathrm{M}$. Feuillet de Conches in his third volume. The answer of Maria Theresa to the authentic letter of the I 4 th of May, is published both by M. von Arneth and by M. Feuillet de Conches in the Supplement to the 2nd vol. p. 44I. The Empress refers in the following terms to the passage we have just quoted:- 'I cannot tell you how much I was touched by the lines the King chose to add to your letter. This is a cordiality I prefer to everything, and his attention in telling me that he is pleased with my dear daughter, and that he thought of me in the first moments of his trying situation, brought 
tears into my eyes. He even says he wishes for advice : que cela est respectable à son âge.' She then proceeds to give the advice asked for, not forgetting to recommend the pardon of $\mathrm{M}$. de Choiseul and his sister (Mdme. de Grammont), and entire confidence in Mercy, 'who is as much your Minister as my own.'

The more the letters published by M. d'Hunolstein are examined, the more evident it becomes that they are precisely such as an ingenious person might compose from the incidents and the gossip recorded in the memoirs and old newspapers of the time. Thus they frequently contain verses supposed to be copied by the Queen, and notices of occurrences of more interest to us than they could have been when they happened; such as the illness of M. de Buffon, the visit of Glück to Paris, \&c. The Austrian collection of the Queen's letters contains nothing of the sort, but, on the contrary, abounds in private details (very fit to be addressed by the Dauphiness to a mother) on her own health and her natural desire to bear children. There is no surer test of the genuineness of a document than the fact that it contains matter of deep interest to the writer, but of no interest at all to future generations. The introduction of details which subsequent events 
have invested with peculiar interest to posterity is in itself a ground of suspicion.

In another of M. d'Hunolstein's letters there occurs a blunder which is of itself decisive. The Queen says (25th of February, I 774), to her sister, 'J'ai pris intérêt à votre Lammerfest, pour laquelle Noverre a fait des merveilles;' and the editor subjoins to this expression a note, to inform the reader that 'Lammerfest' means 'Fête des Agneaux.' Now, it appears that no such lamb-feast as this either is, or ever was, known at the Court of Vienna, but the German critics have taken the trouble to ascertain that at this very time a Kammerball, or Kammerfest (as the smaller court entertainments are usually called), did actually take place there, under the auspices of the ballet-master Noverre. It is evident that whoever framed the letter meant to refer to this entertainment, but the writer (whom we therefore take to be another person) wrote an $L$ instead of a $K$, and converted the word into 'Lammerfest,' which M. d'Hunolstein interprets the 'Fête des Agneaux.'

We are chiefly indebted to M. von Sybel and the German reviewers for the points which have thus far seemed to throw doubt upon a portion of these letters. We are now about to advert to a blunder, 
which has not been noticed in Germany, and which is naturally more apparent to an English eye. Several of the letters in M. d'Hunolstein's collection bearing the date of I79I, and written by the Queen to her brother, the Emperor Leopold, and his ambassador Mercy, during the trying circumstances of that eventful year, are undoubtedly genuine; copies of some of them exist in the Imperial Archives of Vienna, where of course the originals ought to be found, and some others have previously been published in the 'Revue rétrospective.' Amongst the letters of this date, one only is assigned to the correspondence between Marie Antoinette and her sister Marie Christine, Duchess of Saxe-Teschen, and it is the more remarkable as no other letter appears to have been addressed by the Queen to that Princess in the five preceding years. ${ }^{1}$ This letter gives an account of the distressing

1 M. von Sybel argues that as only one letter from the Queen to her sister has been found in the Saxe-Teschen papers, no such correspondence could have existed. But that fact does not warrant the inference, and we have no doubt at all that some correspondence did take place between Marie Antoinette at Versailles and Marie Christine at Brussels. When the Duke and Duchess of Saxe-Teschen fled from the Low Countries after the battle of Jemmapes, their papers and other valuables were embarked on two vessels, one of which was lost, and a portion of the Duke's journal was lost in it. The two volumes of the original journal which were saved are still stained with sea-water. The fact that the letters have not been found does not prove that they never existed; but we very much doubt whether the letters published by M. d'Hunolstein are the documents. 
situation of the Royal Family, and of the implacable hostility of the Duke of Orleans, which the Queen attributes to the exile to Villers-Cotteret, extorted, she says, from the King, by the Garde des Sceaux Lamoignon. It contains a touching and prophetic phrase, which has been largely quoted and commented on in France :- ' They will kill me, my dear Christine; after my death defend me with all your heart. I have always merited your esteem, and that of worthy persons in all countries. I am accused of horrors of which it is needless to say that I am innocent-and the King happily judges of me like a good man. He knows I have never been wanting in what was due to him and to myself.' One would fain believe that these noble and dignified expressions are not the work of a literary forger; but unluckily that which follows renders this belief un tenable. The Queen goes on to speak with affection of the Princess de Lamballe, who, she says, had secretly, and to oblige her mistress, made an arduous voyage to England. And then occurs the following remarkable phrase :-

The Queen and her daughters received her (Madame de Lamballe) favourably : but the mind of the King is deranged. It is the Chancellor of the Exchequer who governs, and he said cruelly and almost in express terms to the Princess that we have brought our misfortunes upon ourselves. (Hunolstein, p. 293.) 
It is not credible that the Queen of France writing at the time could have committed such an anachronism, or could have been so misinformed. George III., as is well known, became deranged in October 1788 ; but on the Ioth of March, I789, he formally resumed the reins of Government by opening Parliament. The King was not afflicted by any serious return of his dreadful malady for several years, and he was certainly in full possession of his faculties in August I79I. It is therefore evident that this passage was inserted by some one who had a vague knowledge of the King's insanity, without having ascertained when it ceased. It is also extremely improbable that the Queen would have described the First Minister of the Crown as the Chancellor of the Exchequer, for though Mr. Pitt held that office he was known as the First Lord of the Treasury; and it is wholly inconsistent with his character or with the feelings he entertained towards the Royal Family of France, that he should have made a brutal speech to the Princess de Lamballe, who was herself so nearly connected with those illustrious victims. In our judgment, therefore, this passage stamps the letter in which it occurs as a spurious production. It is scarcely necessary to quote authorities to prove how entirely the writer 
of the sentence in question has misconceived the real views of the English Ministry and of the King at that time. But there is a passage in a letter from Mr. Burke to his son dated the I6th of August, I 79I, which is so clear and conclusive on the point that it may be worth while to cite it. Burke says :-

Since I wrote the two first sheets I have seen Mr. Dundas, and have received a complete and satisfactory assurance of the neutrality, at least amicable, of this Court. To say the truth, I asked him his opinion directly and without management. But he set me quite at my ease, not only with regard to himself, but to every sub-division of the Ministry, who all agreed, and very heartily, in this point. The King is himself (and I confess, considering everything, it is very generous, and wise, too, in him) most earnest in favour of this cause of sovereigns. $\mathrm{He}$ is constantly asking whether the King of France will be firm and reject the Constitution. (Burke's Correspondence, vol. iii. p. 274.)

It is therefore highly improbable that the Princess de Lamballe or any competent agent should have conveyed to the Queen the false impression contained in her supposed letter.

But this is not all. The second volume of $\mathrm{M}$. Feuillet de Conches' collection furnishes still more conclusive evidence on this point. In August 179I the Count de Mercy made a short visit of curiosity to London: upon his return to Brussels on the 4 th of September he writes to Prince Kaunitz, then Minister at Vienna, an account of what he saw there. $\mathrm{He}$ 
terms it a visit of curiosity, but as the Declaration of Pillnitz was actually signed at the very same moment, it may fairly be supposed that Mercy went to London to sound the disposition of the British Government on the great question of intervention in the affairs of France. He relates that King George III. desired that he should be presented to him, and he infers from the silence affected by Mr. Pitt and Lord Grenville that the English Cabinet was resolved to watch the course of events in a free and passive attitude, and to take advantage of such measures as might be adopted by the other Powers in so important a conjuncture. He also saw Mr. Burke, and on the 2oth of August he sent to the Queen a copy of Burke's advice and opinion. Marie Antoinette knew that Mercy had been to London, for on the $5^{\text {th }}$ of September she writes to him, 'La personne que vous avez vue à Londres est arrivée;' and it appears from another letter of Mercy's that this person was charged by him with a full oral explanation of the state of affairs, to the effect that most of the other Powers had attached to their proposed intervention the condition that England should take part in it. He adds, 'On se rappellera sans doute qu'il avait été prévu depuis longtemps que les plus grands obstacles proviendraient de ce côté-là. 
Malheureusement on ne s'est point trompé, et on s'est mis à même de s'en assurer.' ${ }^{1}$ These passages are extremely interesting on other grounds, because they demonstrate the reluctance of Mr. Pitt and his colleagues to interfere in the affairs of France. But they also establish that Marie Antoinette had at that very moment accurate information from London through far better channels than the Princess de Lamballe, and that she could not possibly have supposed that the King of England was at that time out of his mind.

We have now done with M. d'Hunolstein. His collection of autograph letters appears to us to merit no confidence, and, as we have shown, several portions of them are demonstrably false. No vindication of the authenticity of his publication has been attempted, and before he gave his name to a volume of such questionable pretensions he was bound, we

${ }^{1}$ M. de Mercy knew perfectly well that the neutrality of England was not at that time the sole, or even the principal, obstacle to the intervention of foreign Powers. In a letter from him to M. de la Marck of the 6th September the following passage occurs :- 'Dans le nombre de ces intéressés il en est un qui se refuse de partager les chances qu'il s'agit de courir ; par cela même on peut le regarder, et on le regarde en effet, comme un opposant d'autant plus suspect, que, sous différents rapports, ses convenances contrastent avec celles des autres.' The person here alluded to was the Count's own sovereign, the Emperor Leopold, on whom the Queen's hopes of a foreign intervention principally rested! 
think, to have exercised far more circumspection than he appears to possess.

The case of the collection edited by M. Feuillet de Conches is widely different, and it is an act of great injustice on the part of the German critics to have confounded the two publications together, and to have used against the larger publication arguments suggested by the imperfections and contradictions of the smaller one. M. Feuillet de Conches is a gentleman well known in the' society of Paris and in the world of letters. He fills an important position at the French Court and in the French Foreign Office. $\mathrm{He}$ is the possessor of one of the finest collections of autographs in existence, which serve not only to gratify curiosity but to illustrate history; and he has devoted his life to the critical study of documents of this nature. The correspondence of the Royal Family included in the three volumes already published, consists not only of letters of Marie Antoinette, but of a large number of papers and letters of Louis XVI. and his sister Madame Elisabeth, as well as of other persons of note. These papers are not by any means the exclusive property of the editor, though a portion of them are in his collection, where they are readily shown and may be examined by persons interested 
in the subject. We have ourselves had the advantage of examining a great many of them. But the bulk of the collection published in these volumes consists of inedited letters extracted and copied by M. Feuillet de Conches in the Imperial Archives of Paris, Vienna, and Moscow, and also at Stockholm. In the 'second tirage' of the work, which is now before us, the place of deposit or history of almost every document is carefully noted-a precaution which was unfortunately omitted in the first edition, and which is indispensable to works of this nature. It is certain, therefore, that we are indebted to M. Feuillet de Conches for a collection of the highest interest, and there can be no doubt at all that the vast majority of the letters published by him are perfectly authentic. ${ }^{1}$ But before we pass to the consideration of these historical materials, it is necessary to consider whether $M$. Feuillet de Conches has not been imposed upon to a certain extent by the same ingenious falsifiers who palmed off so many spurious papers on M. d'Hunolstein. In a certain number of instances this must be the case, for some of the controverted letters appear in

1 A special permission was given to him by the present Emperor of Austria, with the concurrence of the Comte de Chambord and the Duchesse d'Angoulême, to take copies of the letters of Marie Antoinette in the Imperial Archives. 
both collections; and indeed the fact is at once suspicious that two collectors of autographs, both in Paris, and both endeavouring to procure papers of the same period, should, without knowing it, have been enabled to procure duplicates of the same papers, both purporting to be in the handwriting of Marie Antoinette. Drafts and duplicates of important political letters may, no doubt, have been kept, though it deserves remark that the Queen expressly adds in a note to the most remarkable of her letters to her brother, 'Keep this, as I may one day like to see it again:' she therefore had no copy of it at hand. But that similar duplicates copied by herself of the familiar notes supposed to have been addressed by her to her mother or her sister, should be in existence, is highly improbable.

Nevertheless, it requires no light evidence to impose on the critical sagacity and experience of such a collector as M. Feuillet de Conches. No one knows better than he does how artfully such documents are fabricated. The world is full, as he says himself, after Madame du Deffand, of 'trompeurs, trompes, et trompettes.' In these very pages he exposes the hoax which led Miss Helena Williams, in 1803 , to publish a volume of imaginary letters of Louis XVI.; and he expresses doubts (which we do 
not share, after having examined the document) of Lord Houghton's celebrated letter (first published by Louis Blanc) from the Comte de Provence to the Marquis de Favras, by which the Prince is implicated in the conspiracy for which that person suffered. $^{1}$ M. Feuillet de Conches is perfectly sincere in his own convictions : he is not credulous ; he is not unskilled in the mysteries of autographs.

1 The letter in question purports to be written by the Comte de Provence to the Marquis de Favras on the Ist November 1789, and it refers to a project for carrying off the King in the following terms : 'Ce plan a en outre l'avantage d'intimider la nouvelle Cour et de décider l'enlèvement du soliveau.' M. Feuillet de Conches thinks this expression cannot have proceeded from the pen of the first prince of the blood, who was one day to mount the throne of France. We are not satisfied with this argument. The expression 'le Roi Soliveau' or King Log is obviously taken from Lafontaine's well-known fable, and it is applied (not without reason) to Louis XVI. in a caricature of the time, of which a copy is in our own possession. This design represents the frogs asking for a king-Lafayette and Bailly answer the appeal. On the apprehension of the Marquis de Favras the Comte de Provence displayed the utmost eagerness to disclaim all participation in his plot, and at the same time to get possession of his private papers. The letter in question was purchased in London by Lord Houghton, not very long ago, from a mass of old documents relating to the French Revolution. It bears strong marks of authenticity. The handwriting is apparently that of Louis XVIII.: the paper has been most carefully and ingeniously repaired; and below the signature is a red stamp ipartly effaced, with the words 'Papiers secrets du procès Favras.' It is written in pale ink. Whatever may be the mystery attached to this document, it certainly bears very strong internal marks of authenticity on the face of it. The existence of this paper is, however, directly opposed to the statements made by the Comte de Provence to the Assembly of the Representatives of the Commune on the 26th of December when he positively declared, 'Je n'ai point vu M. de Favras: je ne lui ai point écrit.' 
We therefore receive with respect whatever he says upon the subject; and the elaborate care with which he has edited these papers is the best proof of the importance he attaches to them.

We shall now leave the disputed question of the authenticity of a portion of these documents, and proceed to extract from those which are of unquestionable authority some of the passages which throw a fuller light on the characters of their authors and the events of the period.

It is worth while to notice how essentially the marriage of Marie Antoinette was a political marriage, and how fatally that circumstance turned to her disadvantage. The system of policy of the Duc de Choiseul consisted mainly in the alliance of France with Austria, by which he hoped to hold in check the Empress of Russia on the one hand, and the Crown of England on the other. In this combination he sought for a system of alliances to compensate in some degree for the losses and humiliations of the peace of $\mathrm{I}_{7} 6_{3}$, and Marie Antoinette was still an infant when she was already marked out to seal the union of the two States by her marriage. The Empress-Queen, in a letter to her young son-inlaw, written just before the nuptials, expressly says, 'I have brought her up with this design; for I have vol. I. 
long foreseen that she would share your destiny.' She did indeed share the destiny of that luckless prince, but in a sense very different from that which her mother foresaw or imagined.

Yet, brilliant as the early fortunes of the young Archduchess were to the outward eye, it is recorded that sinister presages had attended her from her birth. She came into the world on the very day of the great earthquake at Lisbon. At Kehl the gorgeous pavilion prepared for her reception was hung with tapestry which represented the ill-omened nuptials of Jason and Creusa. The personage who received her on the French shore was the Prince Louis de Rohan, worthless and profligate at all times, and afterwards, as Cardinal and Grand Almoner of France, the chief actor in the scandalous intrigue of the diamond necklace. At Paris the rejoicings appointed for the marriage cost twelve hundred lives. Scarcely had the Dauphiness taken her place at Versailles, when M. de Choiseul was thrust out of office by a cabal in which Madame du Barry took the most active part, and the young Princess found herself at a strange Court, without a political friend in the land of her adoption, married to an uncouth lad of sixteen, whose secret prepossessions were certainly adverse to the Austrian con- 
nexion, insulted by the presence and the gibes of the King's mistress, and thrown upon the doubtful society of her aunts and her sister-in-law-the former bigoted old maids, the latter an unmanageable though affectionate child.

Maria Theresa felt, no doubt, the extreme difficulty of her daughter's position, and urged her (as we have seen) to propitiate the Du Barry, and to regulate her own conduct entirely by the advice of M. de Mercy, the Imperial Ambassador. The language addressed to Marie Antoinette by her mother is incredibly severe, but it sounds prophetic : - You must play your part, if you wish to be esteemed : you can do it if you will put some constraint on yourself, and take the advice which is given you; but if you give way, I foresee great misfortunes before you-nothing but quarrels and vexations, which will render your life unhappy.

All this makes me tremble. I see you going on with a certain assurance and carelessness to total ruin or, at least, into a false track.' But in spite of the solemnity of this language, and the deference Maria Theresa exacted and obtained from her children, the marriage of her daughter to the Dauphin failed to give the Empress any political influence at Versailles. Marie Antoinette herself 
had no such influence; but she was made to expiate the crime of the Austrian alliance as bitterly as if she had been its most powerful patroness. It was that circumstance which, for several different causes, first directed against her the malignant intrigues of the Court, and sowed an immense crop of hatred and injustice among the people against an innocent and amiable woman. Maria Theresa was injudicious in inculcating on her daughter, as the first of her duties, the maintenance of the ties with her own country, which her marriage had in fact dissolved, and in constituting the Austrian Ambassador chief adviser of the Queen of France. Mercy, indeed, performed that delicate task with tact and circumspection. The time came when in the whole kingdom of France there was not another man whom Marie Antoinette could really confide in. Nevertheless, it would have been better for her if she had been left to her own impulses; become, as she herself expressed, 'Française jusqu'au bout des ongles,' and not lived to hear that ferocious cry of 'L'Autrichienne!' for ever mingling with the crash of the Revolution. In this respect the policy of Maria Theresa did unintentionally conduce to the fatal termination of the reign of Louis XVI. and of her daughter. 
M. Feuillet de Conches informs us that many of the autograph papers and letters of Louis XVI. which occur in his collection were obtained by himself from the descendants of two of the members of the Convention appointed to ransack the King's private repositories. They probably kept a portion of what they found there for their own use, and since the death of these persons the autographs have been sold. Some of them are of high interest, such as the draft of the Declaration made by the King to the Assembly at the moment of the flight to Varennes, and the confidential letter to his brother, in which he explains his own motives for accepting the Revolutionary Constitution of I79I. The melancholy fate of Louis XVI., the dignity with which he bore the keenest sufferings and turned aside the grossest insults, the piety of his last moments, have contributed to throw over his name something of the radiance which encircles the martyr and the saint. No doubt, in some of his letters, in domestic life, and in the political transactions which cost him his head, it must be acknowledged that he often showed himself a very narrow-minded, ill-mannered, and incapable personage; but these defects are compensated by his genuine desire to improve the condition of his people and to save them from the consequences of their own 
follies and crimes. Many of the earlier acts of his reign do the utmost credit to his heart. The following extract of a letter from the King to Turgot will be read with interest, and we would fain believe it to be genuine :-

\section{Versailles (February 1776).}

I have read with care, Monsieur Turgot, all the Reports you submitted to me at the Council, and the six drafts of Ordinances, which I had previously approved in general terms. I was very glad to make myself master of the details, alone, and in my cabinet. The want of unanimity in my Council on these measures, and the hostility they encounter out of doors, have given me much matter for reflection : but they appear to me to be so useful and so conformable to the welfare of the people, that I cannot hesitate to publish them and to support them with my whole authority. Thus I approve the edict for the suppression of forced labour (corvées) by causing the high roads of the kingdom to be repaired at the common cost. To take the time of a labourer, without his own consent, would be equivalent to a tax, even if he were paid for it : much more if he is not paid for it at all. That is an exorbitant charge on a day-labourer living by his time. You say very wisely that a man who is forced to work and who works without remuneration, works ill. These considerations are palpable, and I regret that an edict so well-founded in reason and equity should have excited so much opposition and distrust, even before it was known : but there are so many private interests opposed to the general interest. The more I think of it, my dear Turgot, the more I repeat to myself, that there is nobody but you and I that really love the people. Have this edict engrossed: I will sign it in Council. (Fenillet de Conches, vol. i. p. 79.)

When M. Turgot was not at his elbow, the King was not always so wise. The naivete of the follow- 
ing passage, in a note to the Garde des Sceaux, Miroménil (written in the year I 775), can hardly be surpassed :-

Have you read the Memorial of the Protestants? It is very well drawn up; but by what right do they dare to print a Memorial and send it to everybody? There may be persons of a misapplied zeal who harass them, which I do not approve, but, on the other hand, they ought to keep within the bounds prescribed to them. They have a sure way to become like all other citizens, and that is to acknowoledge the true religion. (Fenillet de Conches, vol. i. p. 66.)

Whatever Louis XVI. might have been in tranquil times, it is evident that when the tempest of the Revolution was howling about him, his faculties became confused, his irresolution increased, and, like most weak men exposed to dangers he could not surmount, he had recourse to deceit. It would be extremely interesting to trace with minuteness in M. Feuillet de Conches' second volume the fluctuations of the King's mind-the motives which led him to accept the Constitution of I79I (from a conviction, as he acknowledges, that it would not work)-the attempts made to control the Royalist party at Coblenz, and especially the Comte d'Artois-and, nevertheless, the secret conviction of the King that the only hope of salvation for himself and the Queen lay in escape and foreign intervention, though he 
continued to the last to dread and deprecate civil war. But our limits forbid us on the present occasion to enter fully into these curious details, and we must content ourselves with recommending the whole series of the papers, to which no suspicion is attached, to the careful examination of every student of the French Revolution.

There are, however, two short documents in the same volume of this collection, which are so conclusive as to the bad faith of the King in his dealings with the Assembly, that we must find room for them in this place. The Royal Family had been stopped in its flight at Varennes, on the 21st June. And here it may be mentioned that M. Feuillet de Conches relates, on the authority of the Marquis Louis de Bouillé, the anecdote that the actual cause of the failure of the whole escape was that the King, whose appetite was insatiable, insisted on stopping for some time at a house of M. de Chamilly, to eat a meal. It was at St. Ménéhould, a place renowned in French gastronomy for a particular mode of dressing pigs' trotters. That meal cost the King his head, and probably changed the tenour of events in Europe. On the $25^{\text {th }}$ June the Royal Family was brought back to Paris. In the interval the King had been virtually deposed by the Assembly. The catastrophe was all but complete: and the letters relating to it in these 
pages are of a thousand times greater interest than the laboured attempts to describe it in all the daubs and blotches of Mr. Carlyle. At this crisis, then, or a few days later, on the 7 th July, the King addressed to the Constituent Assembly the following message :-

Gentlemen,-I learn that several officers who have passed over to foreign countries have invited the soldiers of their regiments to quit the kingdom and join them abroad, and that this has been done in virtue of certain full powers, directly or indirectly, emanating from myself. I think it right to contradict this assertion and to repeat on the present occasion, what I have already declared, that in leaving Paris my sole intention was to go to Montmédy, whence I should have addressed to the National Assembly the observations I deem necessary on the difficulties attending the execution of the laws, and the administration of the kingdom. I positively declare that every person who may say that he is charged with any such powers on my behalf is a most culpable impostor. (Feuillet de Conches, vol. ii. p. 514 .)

At a preceding page of the same volume (p. I63), we find the following document, also dated the 7 th Fuly r 79I, and headed 'General Powers, which the King, after his arrest at Varennes, sent to the Princes, his brothers, by M. de Fersen!' This autograph paper was given to M. Feuillet de Conches by his friend the Vicomte de Fontenay. It runs as follows :-

I absolutely rely on the affection of my brothers for me, on their attachment to their country, on the friendship of Sovereign Princes, my kinsmen and allies, and on the honour and generosity 
of the other Sovereigns, to agree together on the manner and the means to be employed in negotiations, designed to restore order and tranquillity in the kingdom; but I think that all employment of force ought only to be placed in the rear of negotiations. I give full powers to my brothers to treat in this sense with whomsoever they choose, and to select the persons to be employed for these political objects.

So that on the very same day that the King denied to the Assembly, in terms of apparent indignation, that he had given any powers to promote the emigration of troops, he did in fact send to the heads of the emigration full powers to negotiate with foreign Sovereigns for their intervention in the affairs of France. Two months later, on the I 4 th September, he signified to the Assembly his acceptance of the Constitution-with what sincerity may be inferred from these documents.

In forming a judgment on the terrible events of the French Revolution, it must never be forgotten that this disposition of the Court to rely on foreign aid and to subdue the Revolution by foreign influence, was the inexpiable crime of the King and Queen. It was ridiculous to talk of Louis as a tyrant. It was an outrage to ascribe to the Queen, as a woman, any single action which would not have become the noblest of her sex. Whatever may have been the shortcomings of her Austrian 
education and the frivolity of her early habits, misfortune and danger awakened in her a force of will, a clearness of intelligence, a power of language, and a strength of soul, which speak with imperishable eloquence in every line of the letters written after the commencement of the Revolution. But although these qualities of the Queen do her the highest honour, and in this respect the publication of her most private correspondence can only exalt her reputation, yet these papers render still more apparent the fact that she had but little political judgment, and that neither she nor the King ever conceived the possibility of dealing honestly with the Revolution. At each successive stage in that protracted tragedy, there was a secret policy always at work in the opposite sense, and that policy, relying mainly on external support, was their destruction. A single instance must suffice to explain our meaning. We select it from a letter in cipher, addressed by the Queen to Count Mercy, on the 28th Sept. I 79 I, about a fortnight after the King had accepted the Constitution, and a momentary turn in his favour had been given to affairs, if it had been honestly and ably employed. The language of Marie Antoinette demonstrates the entire insincerity of their acquiescence :- 
It is most important for us to know the exact extent of the engagements of the Emperor and the other Powers with the King's brothers, the measure of their good-will, and the time at which they may effect it. As for this last point, it appears to me from all your letters, and by the dictates of reason, that the time is at least remote. It is this, therefore, which decided us to take, at this moment, the course we have adopted [acceptance of the Constitution].

Anyhow, it was necessary to have the air of uniting in good faith with the people. If public opinion does not change, no human power can govern in despite of it. If then it be necessary to adopt the present system, at least for a time (and it will destroy itself if it be adopted), it is essential that we should be united to that great majority which is the people, and to inspire it with sufficient strength to resist the machinations of the republicans who are seeking every means of influence and found all their hopes on the next legislature.

There is another advantage in having the air to adopt the new ideas-that it is the safest mode of defeating them. When the factious will no longer be able to tell the multitude that the King opposes its welfare by opposing the Constitution, it will be more conscious of the calamities that surround it.

If, on the other hand, as I dare not flatter myself, the Powers find some prompt and imposing manner to make themselves heard here, and to exact the things they have a right to demand for the safety and balance of power in Europe, it is still necessary to inspire confidence. The fear of external force, though it should use no language but that of reason and the common rights of sovereigns, would mitigate the first shock here, and might decide them to entreat the King to act as mediator,-the only part fitted for him, as much from the love he bears his subjects as for the purpose of controlling the faction of the emigrants, who by the tone they assume (which would be raised still higher if they contributed to another order of things) would only plunge the King 
into a fresh slavery. The wisdom of the Powers must therefore restrain them as much as possible. Anything they could do alone or without a paramount force, would destroy them, ourselves, and the whole kingdom. (Feuillet de Conches, vol. ii. p. 392.)

Bertrand de Molleville relates in his Memoirs that the King and Queen accepted the Constitution in a very different spirit. The King said to him, 'I should have liked to introduce some modifications into the Constitution, but it is now too late; I have accepted it as it is; I have sworn to maintain it. I must keep my engagement, and the more so as I think the exact execution of the Constitution is the surest method of convincing the nation that some changes are required in it. I have no other plan than this, and I shall certainly not deviate from it.' The Queen added to the same Minister, 'The King has acquainted you with his intentions relative to the Constitution; do you not think that the only plan to pursue is to be faithful to his oath ?' 'Certainly, your Majesty,' replied Bertrand. 'Well,' said the Queen, 'be sure they will not make us depart from it.' This version of the policy of the Court in September I79I has been adopted by Thiers and other historians. The letter just quoted demonstrates the insincerity of these assurances, and that the hopes of the Queen were entirely fixed on 
the intervention of foreign Powers, with a paramount force, to put down the Revolution. Yet that was the most fatal error the Court could then commit; for, as Brissot declared in his Journal two years afterwards, "Without the war there would have been no Ioth August; without the roth August there would have been no Republic.'

But even the simulated confidence of the King in the Constitution was of short duration. He was grossly insulted on his first appearance in the Assembly by an attempt to refuse him the titles of Sire and Your Majesty; and when he 'vetoed' the law against the émigrés, in November I79I, that act occasioned a definitive rupture.

When Marie Antoinette was brought to her trial, the first question put to the jury was this: 'Is it proved that manœuvres and intelligences with foreign Powers and other external enemies of the Republic have existed, tending to aid and abet their designs? and is Marie Antoinette of Austria convicted of having participated in these manœuvres and intelligences?' This was a crime punishable by death under the article of the Penal Code which Fouquier applied to her. The trial of the Queen was no doubt a mockery of justice. She was outraged and insulted by false and indecent charges, irrelevant to 
the main issue. No real evidence on the main charge of high treason was adduced against her. But if the letters and papers contained in these volumes had been in the hands of her judges, as they are in the hands of posterity, it is impossible, even for those who are most deeply affected by her melancholy fate, to deny that the Queen had actively engaged in the foreign intelligences ascribed to her; that she had used her influence and her resources abroad to arm Europe against France; and that when apparent concessions were made to the new Constitution of the French Monarchy, the Queen never relinquished her uncompromising hostility to the Revolution. 'She was,' to borrow the language of M. Mortimer Ternaux, ' ${ }^{1}$ afflicted by the most cruel perplexities, but these perplexities were not those of the King. Louis XVI. knew not whether he ought or ought not to be a constitutional king. Marie Antoinette knew that she chose he should never be one. Hesitating as to the means she should employ, but never as to her object, she had no fixed system of conduct; she was firm only in repugnance and resentment. . . . She dreaded whatever aid came from the interior, because an

1 Histoire de la Terreur, vol. i. p. 20. 
account must one day be rendered to those who afforded it. She turned her eyes to the armies of the Coalition, without having formed a clear conception of what she needed or what she desired.'

This sentence may seem severe, but it is that of a writer thoroughly versed in the history of the Revolution, full of respect for the Queen's character and of compassion for her unmerited sufferings. And, in our judgment, it is confirmed to demonstration by the voluminous letters extracted by $M$. Feuillet de Conches from the Austrian Archives and by many of the documents in his own possession. From similar sources he has exposed to the light of day the restless intrigues of the émigrés, more especially of the Comte d'Artois and Calonne; the crafty and insincere expedients by which the Emperor Leopold kept alive the expectations of the Court of France without taking any serious engagement; the impetuous but abortive zeal with which Gustavus III. of Sweden was ready to advance, like a knight of old, to the rescue of the Queen; and the artifices by which Catherine of Russia sought to turn the confusion of Europe and the downfall of the French Monarchy to her own advantage. These materials are of the highest interest, and they exhibit the honesty and sagacity of what 
was termed the Coalition in a light not more creditable to the sovereigns of Europe than the honesty and sagacity of the Court of France in its relations with the popular party. On these questions M. Feuillet de Conches has rendered services to the secret history of the Revolutionary period which are only equalled by the publication of the correspondence of the Comte de la Marck, given to the world in $185 \mathrm{I}$ by M. de Bacourt, which is reviewed in the preceding Essay in this volume.

We shall take leave of this part of the subject by citing two interesting letters from the Queen to her brother. The first relates to the negotiations which had been carried on through M. de la Marck between Mirabeau and the Court. It is well known that in order to conceal the game he was playing, that unscrupulous tribune made use of language of increased violence in the Assembly at the very time he was advising Louis XVI. to countermine the opposition of that body to the existing Ministry; but this inconsistency had the effect of destroying the confidence of the King and Queen in the advice he was giving to them. The following letter relates to this subject :-

This 22nd October, 1790 : St. Cloud.

We are fallen back into chaos and all our distrust. M. [MiraviOL. I. 
beau] had sent in some papers, warmly expressed but well argued, on the necessity of preventing the usurpations of the Assembly, and of resisting its pretensions to interfere in the nomination of Ministers. $\mathrm{He}$ had proposed several names, and the King was disposed to examine the question, when, àpropos of some disturbances which have occurred in the fleet, he delivered a violent demagogical speech, such as to terrify all honest men. ${ }^{1}$ Here then all our hopes in this quarter are again overthrown : the King is indignant and I in despair. He has written to one of his friends [M. de la Marck] in whom $I$ have great confidence, and who is a most trustworthy gentleman, a letter of explanation which has just been shown to me, and which appears to me very little calculated to explain or excuse anything. This man is a volcano. who would set fire to an empire : are we to rely on him then to extinguish the conflagration that consumes us? He will have much to do to regain our confidence. At bottom, the King himself felt how important it is to resist the encroachments of the Assembly, which aims at nothing less than the subversion of the royal authority : but how can we induce him to take advice from those who are bursting into fresh excesses? However, a good counsel is always good, and I am urging the Archbishop (Brienne) to speak. Lam. defends Mir., and maintains that though he has occasional outbreaks, he is sincere in his wish to serve the Monarchy, and will repair this flight of his imagination, which did

1 The entire history of this transaction may be found in the correspondence of Count de la Marck with Mirabeau, vol. ii. p. 251. On the 16th October, Mirabeau advised the King to anticipate the vote of want of confidence threatened by the Assembly by dismissing his own Ministers and having a Cabinet taken from the advanced leaders of the Revolutionary party. The King hesitated. On the 18th Mirabeau suspected that the Court was acting under the counsels of a foolish person named Bergasse, whose advice was directly opposed to his own. Irritated by this sign of distrust, he attacked the Court in the Assembly with great bitterness on the $2 \mathrm{Ist}$, and proposed the substitution of the tricolour flag in the navy for the old drapeau blanc. It is to this circumstance the Queen refers in her letter. 
not come from his heart. But the King will not believe it. I saw yesterday he was very angry. Lam. says he doubts not that Mir. thought he was doing right in speaking thus, in order to deceive the Assembly, and gain credit with it in more momentous circumstances. Oh ! God, if we have committed faults, we have keenly expiated them.

The last letter of the Queen for which we can find room is also addressed to her brother. M. Feuillet de Conches prints it from the draft in the Queen's handwriting in his own collection. It is extremely touching and characteristic :-

This 27th December, 1790.

Yes, my dear brother, our situation is dreadful. I feel it, I see it, and your letter has divined everything. Human nature is very wicked and perverse, and yet this nation-I have singular proofs of it-is not bad at heart. Their fault is that they are too impulsive. They have generous movements, which do not stay: they are inflamed like children, and once excited they are led to commit every crime, though they may repent of them afterwards in tears of blood. What is the use when the evil is done? You remind me that I had looked forward to the États Généraux as a source of trouble and the hope of the factious-but since then what ground we have lost! I am daily outraged by insults and threats. On the death of my poor Dauphin [the Queen's eldest boy died in June I 790], the nation seemed totally unconscious of the event. From that day, the people are mad, and I am in constant terror. After having undergone the horrors of the $5^{\text {th }}$ and 6th October, anything may be expected. Assassination is at our doors. I cannot show myself at a window, even with my children, without being insulted by a drunken mob, to whom I have done no harm, and amongst whom there are doubtless unfortunates whom I have myself relieved. I am prepared for any event, and 
I can now, unmoved, hear them crying for my head. My anxieties are increased, my dear brother, by the state of your health : I cannot tell you how much I was affected by the long letter you wrote me from your bed of sickness. I acknowledge your tenderness and I thank you with all my heart; but forgive me, I entreat you, if I still refuse your advice to leave : remember that I am not my own mistress; my duty is to remain where Providence has placed me, and to oppose my own body, if need be, to the daggers of the assassins who would attack the King. I should be unworthy of our mother, who is as dear to you as to myself, if danger could induce me to fly far away from the King and from my children.

Before we take leave of these interesting collections, one class of letters remains to be noticed, which are, from their singular freshness, vivacity, and originality, the most captivating of all. We mean the copious correspondence of Madame Elisabeth, the King's sister, with her two ladies-inwaiting and confidential friends, Madame de Bombelles and Madame de Raigecourt. The authenticity of these letters cannot be questioned, for they proceed directly from the custody of the representatives of the ladies to whom they were addressed. The three sons of Madame de Bombelles entered the Austrian service, and the youngest of them (who had possession of his mother's letters) became the third and last husband of the Empress Marie Louise. Through the Comtesse de Flahault, when Ambassadress of France at Vienna, these letters were commu- 
nicated to the present editor, and they have since been collated with another copy of them belonging to the Marquis de Castéja, who married Madame de Bombelles' daughter in 1819 . Some of the letters of the Princess to her other friend, Madame de Raigecourt, had already been inaccurately given to the world by M. Ferraud; but they have now been revised and published in their integrity by $\mathrm{M}$. Feuillet de Conches from the original documents in the possession of the present Marquis de Raigecourt. We are thus particular in explaining the history of these papers because they are wholly exempt from the suspicions which have been thrown on some other parts of the collection; and it would be desirable to obtain an equally clear and explicit account of every paper to which a great name has been affixed.

No character in modern history lives in a purer light than that of Madame Elisabeth. She shared the sufferings of her brother ; she refused to forsake him when she might have left France; she was of all the victims of the Revolution the purest and the most innocent. But without at all diminishing the admiration inspired by her virtues, these letters exhibit her character from an entirely new and unexpected point of view. Far from being the 
resigned and half-celestial creature who sacrificed herself to the tenderness of her affections and the ardour of her faith, Madame Elisabeth was of all the Royal Family of France the most remarkable for the extreme vivacity of her disposition, for her brilliant humour, for her high spirits and enjoyment of life, and for a proud sense of what was once her own great position. Born a Princess and a child of France, she exulted in the pleasures she possessed and the pleasures she could confer on others. To her tastes, her habits, and her ardent convictions, the Revolution, with its brutality and its irreligion, was abominable. From the first day when the storm broke on the marble galleries of Versailles, she retained no illusions, she advocated no concessions. Her courageous heart would have found it easier to break in a bold resistance than to temporise and exhaust the slow torments of lingering destruction. Yet that was the fate to which she was doomed by the fault of others, rather than by her own; and with a complete knowledge of the extent of that hopeless sacrifice, undeceiving and undeceived, she made it, not only without a murmur, but with a gaiety and gallantry of heart, tempered only by her profound faith in the justice of God and the truth of $\mathrm{His}$ religion. She met those perils- 
she describes those scenes of horror-with a light and unshrinking touch. Even when you trace in the animated irregularity of her style the futter of the keenest emotion, half-concealed from the friends she was addressing, she shows not a sign of fear; and she allows nothing to check the natural flow of her spirits, except the consciousness of her own imperfections, measured by the standard of divine endurance and divine purity. Yet, with these elevated thoughts and motives ever present to her mind, she is not a whit the less a woman of the world, eagerly sharing in every pursuit and enjoyment and passion of the hour, and owning that it costs her more to relinquish her horses, her gardens, her dairy, and her freedom, than she cares to admit. This strong infusion of youthful gaiety and active tastes, mingled with the fervour of her religious sentiments, gives a new aspect to the character of Elisabeth; but it only renders her more attractive and more original.

We can hardly hope to preserve in a foreign language the peculiar playfulness of her style in these letters, but the following extracts may give some idea of them. The first in the series was written to Madame de Bombelles the day after the capture of the Bastille :- 
I 5 th July, 1789.

How kind you are, dearest ! All the dreadful events of yesterday had not made me cry; but your letter, which gives me the consolations of your friendship, has cost me a flood of tears. I should be grieved to go away without you. I don't know whether the King will leave Versailles. I would do whatever you wish, if that were to happen. I don't krow what I really desire on that point. God knows what is best to be done. We have a pious man at the head of the Council, perhaps He will enlighten him. Take care of yourself and pray don't come out-though, ma petite, I make the sacrifice of seeing you. I love you more than I can tell. At all times, at every moment, I shall feel the same. I hope the evil is not so great as one imagines. What makes me think so is the quiet of Versailles. We were not quite certain yesterday that $M$. de Launay had been hanged: somebody else had been taken for him. I shall cling, as you advise me, to the chariot of Monsieur (the Comte de Provence), but I am afraid the wheels are good for nothing. Adieu, dearest, I embrace you as fondly as I love you.

Here follows an outburst from the brave little fanatic, whose religion was not always of the most saintlike temper :-

Paris, 2oth January, 1790.

As this letter will not see the post-office in France I may write to you rather more at my ease. The Assembly has crowned the measure of its follies and impieties by giving to the Jews admission to all offices. The debate was long, but the right-minded people had, as usual, the worst of it. As yet they have only admitted the Jews who had privileges; but you will see the whole nation will soon have the same advantages. It was reserved for our age to receive in friendship the only people whom God has marked with 
a sign of reprobation, to forget the death inflicted on our Saviour by that people, and the benefits that Saviour has ever scattered over France. I can't tell you what a rage I am in at this decree. But we must wait and submit with resignation to the punishment reserved to us by Heaven, for this offence will never be allowed to remain unavenged. Our present position proves that God has $\mathrm{His}$ days of vengeance, and that if $\mathrm{He}$ is long-suffering of evil, $\mathrm{He}$ does nevertheless punish it with force, when the ingratitude of mankind has reached its height.

You will see, or you have already seen, what the Assembly has done to prevent its members from holding offices. [The Assembly had just decreed the non-re-eligibility of its members.] I don't know that it is a good thing. I am afraid it will only render them more violent. Since the King has taken this step, which puts him, as they say, at the head of the Revolution, and strips him, as I say, of the little remaining crown he had still on his head, the Assembly has not done a thing for him. It is fiercely bent on the destruction of the Clergy. To-day they are going to decide that there are to be no eldest sons. Every sort of extravagance is going on, and no good will come of it.

Ist March, I790.

We are not yet sure that the Emperor (Joseph) is dead. But one might lay a wager it is so. How Europe will be knocked about! They say his niece has died in her confinement: the happier she, though I am not envious of her lot. As I have always been extremely curious, I should like to see the end of this Revolution. Yet if the days of persecution for the faith were to return, ah ! I would ask Heaven to release me from the world first, for I don't feel I have at all the courage to support it. It is true that there is an old proverb which says 'God tempers the wind to the shorn lamb,' and I doubt not that we should experience it, if the time came. You will think me rather mad. For 
fear you should find out that you are not erring in thinking so, I leave you and embrace you with all my heart.

These touches must suffice to give an impression of the Princess's character-ardent, intolerant sometimes, resolute in opposing danger, dauntless in exposing deceit, foreseeing more clearly than others the track that lay before her, shrinking at times from the shadows that crossed it, but pursuing it at last to the bitter end, in faith and love not unworthy of her Divine Master.

Whatever may have been the errors of judgment and the defects of character of the members of the Royal Family of France-and, as we have seen, they are unreservedly laid bare, by themselves, in these confidential letters to their nearest connexions -it can never be forgotten that their unparalleled misfortunes plead like angels' tongues in their favour. No doubt it may be easy to trace even those misfortunes, in part, to the singular want of tact and resolution exhibited by the $\mathrm{King}$ in all the important emergencies of his life-to the wilfulness of the Queen, her inexperience of politics, and her foreign extraction-to the total want of intelligence of the time and of the Revolution, from which even the acuteness of Madame Elisabeth did not exempt her. But with the whole evidence now before the 
world, which enables us to follow them into the recesses of their thoughts and feelings, we rise from the perusal of these papers with increased sympathy with sufferings borne in so noble and Christian a spirit. 
$-$ 


\section{BEUGNOT.}





\section{BEUGNOT:}

THE reminiscences of a man of spirit and intelligence, who had seen the condition of French society before the Revolution of I 789-who shared and survived the dangers of I 793-who took an active part in the Imperial administration under Napoleon -and a still more active part in the restoration of the Bourbons and the establishment of constitutional monarchy in France, are amongst the most instructive and entertaining memorials of modern history. We opened these volumes with high expectations, which have not been disappointed. They are really a valuable addition to the literature of the French Revolution; and they supply many of those happy touches and characteristic incidents which serve to complete the picture of that extraordinary period. Portions of these memoirs had

1 This paper was first published in the Edinburgh Review, No. 256, for April 1867, as a review of the following work:-Mémoires du Comte Beugnot, Ancien Ministre (1783-1815). Publiés par le Comte Albert Beugnot, son petit-fils. Deux tomes. Paris : 1866 . This book has since been translated and published in England, but in 1867 it was not known in this country. 
already appeared in the 'Revue française' of 1838 , and the 'Revue contemporaine' of 1852 ; indeed the additions now made to these fragments are not large, and it appears that the remainder of M. Beugnot's autobiographical papers, to which allusion is frequently made by himself, are no longer in existence. The memoirs therefore retain their fragmentary character, and, for once, we are assured that we possess them in their true form. This can so rarely be said of the French memoirs of the day, that we must express our gratitude to the Beugnot family that they have not allowed any hired hand to ' make up' or mutilate their literary inheritance. They have published whatever had come down to them, without any attempt to supply gaps or invent transitions. These volumes appear under the sanction of the highly respectable name of the author's grandson; and although the epigrammatic and dramatic style in which they are written might awaken some suspicions, yet we believe in their authenticity and credibility.

Memoirs may be divided into two great classesthose which are really contemporary, with all the fluctuations and contradictions of current opinion, and those which are recast afterwards when the events to which they relate are terminated. A 
writer with the graphic powers of a Saint-Simon may by the latter process leave to posterity a more complete picture of a great reign, or may, with the sedate wisdom of Count Mollien in his invaluable records of the First Empire, raise his personal reminiscences to the dignity of history. But in point of vivacity and reality nothing can make up for the freshness of a recent impression. We feel in the present tense, though we reflect in the præterperfect. And the nearer a writer can bring us to the scenes he is describing, the more completely does he master our sympathy and our interest.

M. Beugnot was born in I76I at Bar-sur-Aube, where his family belonged to the noblesse de robe of the province, and he himself was brought up to fill a legal office before the Revolution. He gives us no details, however, as to his early life, and the narrative of his adventures begins with a relation of his curious acquaintance with the notorious Madame de Lamotte. It seemed extremely improbable that anything more remained to be said of the affair of the Diamond Necklace-that scandalous intrigue which had so disastrous an effect on the fortunes of Marie Antoinette. But, as Madame Campan observes, of all the enemies of the Queen, this Lamotte was destined to be the worst; and a cabal voL. I. 
which originated in vanity, lust, and avarice-in which Marie Antoinette had no part but that of a victim-was more injurious to her than her own social failings or political errors. Madame de Lamotte was probably the authoress of the whole plot, unless indeed she was aided in it by the sinister genius of Cagliostro. By a strange series of accidents, M. Beugnot, himself one of the most honest of men, was in the company of this woman at the most critical moments of her life, and might, on less evidence, have been thought to be implicated in her villany.

It must have been about the year I 765 , that $M$. Beugnot's father, going his rounds to levy the taille in the country near Bar-sur-Aube, was entreated by the curé of the parish of Fontête to relieve three children who were starving in a wretched hovel by the roadside. These children, a boy and two girls, were the last descendants of an illegitimate branch of the House of Valois, through a Baron de St. Rémi who was a natural son of King Henry II. Their father, in spite of his high lineage, was no better than a tramp, who lived by poaching and robbing orchards. But his pedigree was incontestable and had been accepted by Chérin, the court genealogist of Louis XV. Moved by the extreme 
distress of these children, an effort was made by Beugnot the elder to provide for them in the neighbourhood. He himself gave them some money. The Bishop of Langres protected them. The King at last bestowed on the boy a pension of 1,000 livres, and an admission to the Naval School of France. The girls were put to school at the Abbey of Longchamps near Paris, and so the last descendants of the Valois were brought back to civilised life. The boy, called the Baron de Valois, entered the navy and honourably lost his life in action. The girls were destined to take religious vows; but their vocation was so small that when the subject was broached they ran away from Longchamps, and found their way back with six livres in their pocket, in 1782 , to Bar-sur-Aube, where young Beugnot was then just beginning to make a figure in the world. It is evident that he was not a little taken with the elder of the young ladies, to the great alarm of his father, who regretted that he had ever dug them out of the hovel by the roadside. A benevolent lady of Bar-sur-Aube, Madame de Surmont, shocked at the destitute condition of these young persons of quality, invited them to her house ; they stayed there a year, and the eldest young lady, who might have sat for the moral traits of Mr. Thackeray's 'Becky 
Sharp,' began her operations on mankind by making her ascendancy felt in the house of this hospitable protectress, and marrying her nephew, M. de Lamotte, who was then serving in the gendarmerie of the department. The happy pair had nothing to live on but their wits; and while the bride dispatched her husband to reclaim the missing estates of the House of Valois, she lost no time herself in repairing to Paris. The portrait of this terrible adventuress is not ill drawn by M. Beugnot.

Madame de Lamotte was not what is called beautiful ; she was low in stature, but well-formed; her eyes were blue, full of expression, and shaded by dark rounded eyebrows. Her face was rather long, with a good mouth and excellent teeth; and the peculiar stamp of her kind-a bewitching smile. Her hand was good, her foot small; her complexion remarkably fair. She had learnt nothing, but she had plenty of talent and penetration. As she had been contending from her birth against the whole order of society, she set its laws at defiance and those of morality as well. She passed clean over them all, as if she never suspected their existence. A character such as hers is a frightful spectacle to an observing eye, but seductive enough to the common run of men who do not look at things so closely.

Meanwhile young Beugnot had come up to Paris for his legal studies, and he soon received a visit from this interesting client. He looked up for her the old patent of Henry II. in the archives which had settled certain estates on her ancestor, wrote a 
memorial in support of her claims, paid a bill for her several times over at the Hotel de Reims, and prevailed on her once or twice a week to dine with him at the Cadran Bleu. On other days they took a walk together, which generally ended in a café.

The lady had a singular love of beer, and no beer came amiss to her. She would eat, out of pure inadvertence, two or three dozen tartlets; and these inadvertences were so frequent that I could not but perceive that she had dined very lightly, if at all.

However, this state of depression soon came to an end. She announced one day that Madame de Boulainvilliers had obtained for her the honour of an audience of the Cardinal de Rohan, and Beugnot lent her his carriage to go there. 'I must have it,' said she, 'for in this country there are but two ways to go begging, either at the church door or in a coach and pair.' The results of that visit were memorable in all history. The Cardinal, himself a profligate and an adventurer in his way, was completely subdued by the grace and address of the fair supplicant. It is certain from a collection of letters from him to the Lamotte, which were luckily destroyed by Beugnot after his arrest, that he was madly in love with her; and from that moment her progress in the path of vice, guilt, and success was rapid. She therefore smilingly informed her friend 
Beugnot (still at the Cadran Bleu) that he could no longer be of any use to her. But in this she was mistaken. For a time, however, he withdrew from her society, and she transferred her operations to Versailles, where she succeeded in making the acquaintance of persons about the Court who had already practised on the Queen. It soon became evident that she had made her fortune and lost her character; but with singular impudence she and her husband came back to pay a visit to their old friends at Bar-sur-Aube (who received them at first very coldly) with a splendid equipage, a profusion of money, and all the luxury of a great lady-accessories which speedily led people to take a more favourable view of their condition.

Madame de Lamotte's house in Paris in the following year was not less brilliant and agreeable; and there Beugnot, at his own request, met Cagliostro -a worthy member of such a company.

The great mountebank seemed cut in the very mould of Signor Tulifano (the Dulcamara of that day) on the Italian stage-short, stout, olive-coloured, with eyes half out of his head, and a broad turned-up nose. He wore that day an iron-grey single-breasted coat embroidered with gold, a scarlet waistcoat with rich lace, red breeches, his sword under the tails of his coat, and a broad hat with a white feather-looking very like those drug-sellers and tooth-drawers who perform at fairs. But Cagliostro raised the character of his dress by his lace ruffles, sparkling rings, and shoe- 
buckles looking very much like diamonds. I still looked askance at him, hardly knowing what he was like ; but, in spite of myself, the whole aspect of the man had something imposing about it, and I wanted to hear him talk. His language was a strange mish-mash of Italian and French, with numerous quotations, which he gave us to understand were Arabic, but which he did not translate. He alone talked-he could touch on as many subjects as he pleased, as nobody else had anything to say about them. Every moment he looked round the table, and begged to know if he was understood; at which everybody round the table bowed assent. When he began a subject he raised his voice as if he were inspired, and then dropped into a tone of gallantry and ludicrous compliment. This lasted all supper-time, but all I understood was that the hero had been talking of the sky, the stars, the Grand Arcanum, Memphis, the hierophant, transcendental chemistry, giants, big beasts; of a city bigger than Paris in the interior of Africa, where he had numerous correspondents; of our ignorance of a thousand things which he had at his fingers' ends ; and of the charms of Madame de Lamotte, whom he called his dove, his gazelle, his swan, \&c. After supper he honoured me with a round of questions, but as I contented myself with humbly expressing my own ignorance, I was afterwards assured by Madame de Lamotte that he had conceived the most favourable impression of my person and my attainments.

I returned home on foot and alone. It was one of those nights of spring, when the moon seems to lend the softness of her light to the promise of the coming year. The town was quiet and solitary, as it commonly is in the Marais after midnight. I stopped in the Place Royale to meditate on the scene which had just passed before me. I thought with bitterness of mankind, when I saw to what depths of extravagance men sated with all the gifts of fortune and society may descend. I thought with compassion of that wretched Cardinal de Rohan, whom Cagliostro and the Lamotte are, I see, driving to the abyss. But is my own 
curiosity so venial? What have I to do in this gilded cavern of people whom I despise and whom I ought to abhor? I contrasted these scenes with the early impressions of my father's house and of my studious years, and, condemning my own weakness, I resolved to separate myself from Madame de Lamotte and her band without a rupture, but altogether.

A more illustrious victim than the Cardinal de Rohan was threatened by these machinations, and by a curious accident Beugnot was again thrown into Madame de Lamotte's company at a most decisive moment. He had gone to call one evening on a person from his own province whom Madame de Lamotte had made her companion. That lady herself was out, but as the evening wore away she returned, accompanied by her husband, her secretary, and a remarkably handsome well-grown girl of about twenty-five. They were all in the highest spirits, the unknown beauty as well as the rest; and as supper was served and the wine went round, she became noisy. Villette (the secretary) said that ' it was not true that people were always betrayed by themselves; that everybody betrayed you; and that___ Here Madame de Lamotte, next whom he was sitting, put her hand to his mouth, and exclaimed, 'Hush! M. Beugnot is too honest a man to hear our secrets.' The conversation thus interrupted, Beugnot was sent home in Madame de Lamotte's 
carriage, accompanied by the tall young lady, whom he dropped on his way at the Rue de Cléry. That young lady was Mademoiselle Oliva, who had personated the Queen in the scene when she gave a rose to the Cardinal in the bosquet at Versailles. The trick had been played that very evening, and by this strange accident Beugnot had supped with the actors. From that moment the mystification of the Cardinal was complete, and the Diamond Necklace was in the grasp of the gang.

Strangely enough, after the extraordinary success of the plot, the Lamottes not only did not leave the country with their plunder, but they had the folly and audacity to return to Bar-sur-Aube, where they were well known, to exhibit it. They openly displayed enormous wealth. Waggons loaded with splendid furniture came down from Paris. Two complete services of plate glittered on the sideboard. They even exhibited a casket of diamonds of great value, and a multitude of costly articles of jewellery. All this was set down to the infatuation of the Cardinal, but it created distrust, and in the better houses of the province Madame de Lamotte was in very indifferent repute.

She still succeeded, however, in pushing herself into society, and on the 17 th of August 1785 she 
was even received by the Duc de Penthièvre at his seat at Châteauvilain, with honours only paid to persons of high rank. Beugnot was staying at that moment at the Abbey of Clairvaux, with Dom Rocourt the Abbot, a very strange successor of St. Bernard; the Abbé Maury was to preach next day the annual commemoration of that great saint at the monastery. Dom Rocourt was so good-looking that, when he was presented at Versailles, the Queen called out, 'Ah! le beau moine!' and he was in other respects a well-appointed gentleman, having 400,000 francs a year, and never travelling without - four horses and an outrider. With this gay abbot, in his abbey, Madame de Lamotte, on her way back from Châteauvilain, came to dine, and in her avowed character of the mistress of a Prince of the Church, she seems to have thought she had a claim to figure at its ceremonies. This the Abbot declined, but he invited her to supper; and to this same supper arrived fresh from Paris the preacher of the morrow's feast. They sit down at once to table, and the Abbot, impatient of news from Court, challenges his guest for the last news from Versailles. 'What news ?' replied Maury, ' where do you live then? There is news which astounds all Paris. The Cardinal de Rohan, High Almoner of France, was 
arrested last Tuesday, on Assumption Day, in his pontifical robes, at the door of the King's closet.' 'Is the cause of so violent a measure known?' 'Not exactly; but they say it is about a diamond necklace he was to have bought for the Queen, and did not buy. It is strange for such a trifle that they should have arrested the High Almoner of France.' We continue the story in M. Beugnot's words :-

No sooner had this news reached my ears, than I looked at Madame de Lamotte, who had dropped her napkin, whilst her pale and motionless face hung over her plate. After the first effort, she sprang up and rushed out of the room. One of the Abbot's attendants followed her, and I shortly rejoined her. She had already ordered her carriage and we started together. 'Perhaps I was wrong to come away so abruptly,' said she, 'especially in presence of the Abbé Maury.' 'Not the least. Your relations with the Cardinal are known, and almost avowed. His life may be in danger ; your part is to anticipate the letters, the couriers, the news. But what is the cause of his arrest?' 'I can't conceive, unless it be some trick of Cagliostro's. The Cardinal is infatuated with that man, though I have never ceased to warn him.' 'Very well : but what is this affair of the necklace?' 'All Cagliostro.' 'But you received the fellow at your house. Are you sure he has not compromised you?' 'Not at all. I am sorry I left the supper. But there is nothing that fellow will not say.' 'Madame de Lamotte,' rejoined I, 'you have already said more than I care to hear; but I still offer to render you a last service. It is now ten o'clock. Your husband can join you in an hour with your valuables. You can reach Châlons to-night, whence you may gain the coast, and get a boat for ten louis to carry you to England.' 'Nonsense,' she replied, 'I have nothing to do with this affair.' 
'At least,' I added, after a silence of half an hour, 'as soon as you get home, burn every paper which might compromise the Cardinal. You owe that to his honour and to your own safety.' To this she assented, and on arriving at her apartment we at once opened a great box of sandal-wood filled with papers of every size and every colour. I asked her whether they contained any bank-notes, and on her answering in the negative, I proposed to throw the whole into the fire. This she refused to do, and insisted on our going through all the papers. Then it was that I saw what ravages the delirium of love, rendered more intense by the delirium of ambition, had wrought in this unhappy man. It is fortunate for the memory of the Cardinal that those letters were destroyed, though they would have formed a strange page in the history of human passions. But what must that age have been in which a Prince of the Church would not hesitate to write and to sign letters to a woman whom he knew so little, which in our days no man with. an atom of self-respect could even read to the end ?

I saw, too, in this box letters from Boehmer and Bossange. speaking of the necklace, and of terms of payment ; and threw all into the fire. The operation was a long one. When I left Madame de Lamotte her chamber was reeking with the smell of burnt paper and sealing-wax. It was then three in the morning. She promised to go to bed. But at four o'clock she was arrested, and at half-past four on her way to the Bastille.

Lamotte, the husband, effected his escape to England, no orders having been given to arrest him at the same time. The police, indeed, showed an extraordinary want of vigour in the whole affair. The arrest of the Cardinal took place at noon on the $5^{\text {th }}$ of August. He at once denounced Madame de Lamotte as the authoress of the plot. Yet it was 
not till the 18 th that she was taken at Bar-sur-Aube ; and, as the warrant for the apprehension of her husband was sent down five days later, he had ample time to fly to England, and to carry off the diamonds which were the fruit of the robbery. ${ }^{1}$

Our limits forbid us to dwell on the sketches M. Beugnot has left us of the society of France at the outbreak of the Revolution; yet they are extremely characteristic. In spite of all the. signs which announced the coming storm, it was impossible for the country-gentleman to believe it. Had not the King an army of 550,000 men to maintain order? What could persuade Dom Rocourt of Clairvaux that the Abbey and the Rule of St. Bernard were to be swept from the face of France? What could induce the great lady to believe that she was of less consequence in the vast medley of life than the daughter of an apothecary? When the danger became more apparent, Madame de Brionne, like many others of her rank, prepared to leave the country. The Bishop of Autun (Talleyrand) remonstrated with her, and advised her to take refuge in

1 The husband, who was known under the strange name of M. Mustiphragasis in his later years, died in Paris as late as the year I831; but he had fallen into such extreme indigence that he was in receipt of the charitable relief bestowed upon the poorest members of the community-in fact, he literally died a pauper. 
some small provincial town, where, if she lived quietly, no one would remark her. 'A small provincial town!' exclaimed the Marchioness- ' No, M. de Périgord; paysanne tant qu'on voudra, bourgeoise jamais!' The whole country took up arms. The fear of brigands put a weapon into every man's hand. The manor-house was to be defended by a few rusty fowling-pieces. The game was swept off the country. The fish-ponds were dragged in front of the château. The tiers-état, in the form of three or four drunken peasants, assumed a sovereign jurisdiction over the roads. M. Beugnot witnessed these scenes with vexation and regret, but he was returned to the Legislative Assembly as the deputy of Bar-sur-Aube, and played his part in the abortive work of that illustrious body.

His participation in the legislative labours of the Revolution did not, however, exempt him from his dangers. He had rendered himself obnoxious to the hatred of the revolutionary party by moving the decree of accusation against Marat; and early in I 793 he learned that a warrant had been issued for his apprehension. The only alternatives were imprisonment or flight. With patriotic confidence he chose the former, and resolved to abide the worst. He placed his money and his papers in the hands 
of a couple of friends, who robbed him ; and putting 'Epictetus,' 'Marcus Aurelius,' and 'Thomas à Kempis' in a bundle with a few clean shirts, he prepared for the Conciergerie. At the moment of his seizure he wished to add a volume of 'Tasso' to his packet, but the title of 'Jerusalem Delivered' was regarded as suspicious. 'Tout ce qui vient de Jérusalem ne sent pas bon,' said the ruffian who had him in his power, and 'Tasso' was left behind. As he reached the entrance of the prison, the long steps of the Palais de Justice were crowded like an amphitheatre with ferocious wretches watching for the departure of the death-cart and the arrival of fresh victims. As he got down the whole mass rose screaming, clapping, and vociferating like cannibals. The hapless prisoner was pelted with nameless filth, and he might judge by his entry into the prison of what awaited him on leaving it.

His first three nights were spent in a dungeon with a murderer and a thief. It was by mistake he was placed there, but mistakes were common in the Conciergerie; and perhaps the company of the worst criminals underground was less perilous than that of the political victims up-stairs. Interest had, however, been made for him, and he was shortly transferred to the Infirmary, as the best part of the 
prison. Here the sick, the dying, and the dead were thrown pell-mell on some thirty or forty wretched beds-no air, no ventilation, no cleanliness; a brutal doctor gave twenty minutes once a day to forty patients, and every form of outrage and suffering were heaped upon the miserable inmates of that den of horror. Yet here, and in an adjoining room, Beugnot found himself once more in the presence of friends with whom he had sat in the Legislative Assembly, and as his imprisonment was, by a rare exception, prolonged for four months, he may be said to have undergone the Reign of Terror in the very crucible of human suffering.

First came the Girondins. Seven of them shared his room. At two in the morning, on November 2, the gaolers entered the cell with torches, to make an inventory of their scanty possessions and sweep these illustrious victims away to judgment and the scaffold. Amongst these men, remarkable for the difference of their characters and the similarity of their fate, was Fauchet, the ex-Bishop of Calvados, who retained his attachment to the Catholic faith with the zeal of a martyr. Every day he read his breviary, a portion of Scripture, and a chapter of the Imitation of Jesus Christ. But his favourite study was the Apocalypse, for in that he fancied 
that St. John had predicted the Jacobin Club, the reign of Robespierre, the 'noyades' of Carrier, and even the 'carmagnoles' of Barère. Gensonné and Brissot listened with amazement to the fervour of his harangues.

Next came Bailly :-

$\mathrm{He}$ entered the prison with a serenity worthy of one of the lights of the age. No complaint, no reproach, passed his lips in the six days during which he stood before that mock tribunal. $\mathrm{He}$ gave his answers to the end with the same coolness, precision, and dignity, though ore's blood boils at the questions they put to him. No doubt especial orders had been given to make him drink of that bitter cup drop by drop; for, in the prison, where he had formerly brought the consolations of kindness and humanity, when he stood at the height of fortune and of fame, he was now treated with every refinement of barbarity. When the hour came for his attendance before the Court, his name was called out first, and, as he approached, the gaolers pushed him backwards and forwards, shrieking, 'Tiens-voilà Bailly! à toi Bailly! prends donc Bailly!' he meanwhile moving with gravity through this dance of cannibals.

The day before his death, Bailly anticipated what was to happen, and spoke of it without emotion. 'The public has been misled about me,' he said ; 'I hope the simple execution of the judgment will content them ; but the police will keep order.' 'What,' said I, ' were you deceiving us by the tranquillity you showed, and the confidence you expressed?' 'No,' replied Bailly, 'but I was giving you an example of never despairing of the laws of your country.' The next morning early he took a cup of chocolate, and afterwards two cups of pure coffee. I expressed surprise at his taking the coffee upon the chocolate. 'I took the chocolate,' said Bailly, 'because it is nourishing and soothing, but as I have a VOL. I. 
difficult passage to make, and I distrust my own temperament, I took the coffee in addition, because it excites and stimulates me, and I hope with this diet I shall reach the end of my journey.' At that moment his name was called, and for the last time I embraced him. He wished me a happier fate, and thanked me for the interest I had shown him.

One of the next victims in this strange group was Madame Roland. M. Beugnot's impressions of that remarkable woman correspond with singular precision with those to be derived from her own Memoirs. There was much of harshness and extravagance in her devotion to the ideal of antique Stoicism, and her revolutionary opinions were odious to Beugnot. But in spite of the unfavourable prepossessions with which he saw her in that hall of Eblis, the grace and dignity with which she bore her misfortunes and prepared to meet her doom were irresistible.

The day Madame Roland was to take her trial, Clavières sent me to her on some errand. I would have refused, but Clavières insisted, observing that an interview between her and himself on that day might be injurious to both of them. I went therefore; and watching the moment at which she left her room, I joined her as she passed. She waited at the bars till she was called. Her dress was careful; she wore a gown of white muslin, trimmed with blonde, and fastened round the waist by a sash of black velvet. Her hair was dressed; she wore a light and simple bonnet, and her beautiful locks fell waving on her shoulders. Her face seemed rather more animated than usual; her colour was lovely, and she had a smile upon her lips. With one hand she 
lifter the train of her gown, the other hand she surrendered to the crowd of women who surrounded her to kiss it. Those amongst them who best knew what awaited her sobbed aloud, and commended her to Providence. No words san describe that picture.

Madame Roland answered them all with affectionate kindnes ; ; she did not promise them to return; she did not tell them she was going to die; but the last words she spoke to them were words of tender advice. She exhorted them to be united, to be brave, to hope, and to show the virtues which became their position. An old gaoler, named Fontenay, whose good heart had resisted for thirty years his harsh duties, cried as he opened the gate. I acquitted myself of Clavières' errand; she answered me briefly and with firmness. A phrase just begun was interrupted by the turnkey who summoned her into court. At that signal, terrible for anyone but herself, she stopped, and, taking me by the hand, she said, 'Let us make it up, sir ; the time is come.' Raising her eyes to mine, she perceived I was struggling to repress my tears and was extremely affected. She seemed touched by my sympathy, and added but two words, 'Courage! courage!'

The women's quarter in the Conciergerie exhibited, even more than that occupied by the men, all the varied emotions of that extraordinary time. A corridor was common in the daytime to both sexes, and here there was as much dressing, talking, flirting, and love-making as in the salons of Paris. Most of the women contrived to change their dress three times a day, though in the interval they had often to wash or mend the garment they were about to put on. The tone of conversation was gay and animated, and people seemed bent on proving that 
though the Reign of Terror might imprison and kill them, it could not make them dull or disagreeable. All ranks of society were blended in this singular promenade, and it sometimes happened that those who had sunk to the lowest grade in life, rose again to dignity and honour at the near approach of death. When the Duc du Chatelet was brought to this prison he was totally unnerved by his position-a rare instance-and moreover he was intoxicated. The next day he recovered his senses, but not his composure, and stood bewailing himself at the bars of the women's chamber. A poor girl of the town, named Églé, hardly twenty years old, who had been sent to prison because she hated and denounced the Revolution, said to this disconsolate nobleman, ' $\mathrm{F}$ idonc, Monsieur le Duc! are you crying? Know, sir, that this is a place where those who have no name may gain one; and those who have a name ought to know how to bear it.' The ruffian Chaumette had his eye on this girl, and proposed that she should be tried at the same time as Marie Antoinette and sent to the scaffold on the same tumbril. But even the monsters of that day recoiled from this execrable insult; the Queen was executed alone; and Églé was reserved for the next occasion. Three months elapsed, and if she had held her tongue she 
might have been forgotten, but her language was so violent that Fouquier resolved to make an end of her. The indictment which had previously been drawn up against her was still used on her trial, and she was literally condemned for having conspired with ' la Veuve Capet' against the liberties of the people. Églé was proud of her indictment, but indignant at the detestable lies it contained with reference to the Queen. "If they had sent me to the scaffold with her,' exclaimed the girl, 'they would have been preciously taken in.' 'How so ?' said Beugnot. 'Why, in the middle of the street, I would have thrown myself at her feet, and neither the executioner nor the devil should have removed me.' On her trial she abused the Revolutionary Tribunal in set terms, and poor Églé was sent to the guillotine as an incorrigible aristocrat, like many a better woman.

While these and a multitude of other similar scenes were passing around him, Beugnot himself had the good fortune not to be brought up for trial. The case against him was not very clear, and a letter written by him to Lafayette some months before, which would infallibly have cost him his head, escaped the notice of his enemies. Meanwhile his wife, who was in Paris and at liberty, was unremit- 
ting in her exertions. She came to see him in the disguise of the woman who washed his linen, and at last, at the most critical moment of his life, she succeeded in obtaining his removal to La Force, another prison reserved for persons less gravely compromised. Here he remained for some months longer, not without imminent peril; he was not liberated until after the fall of Robespierre on the Ioth Thermidor.

At this point a gap occurs in the fragments that remain of M. Beugnot's Memoirs. We pass in a moment from the sanguinary gloom of the Reign of Terror I 794, to the active and prosperous career of an Imperial Minister in I808. After the 18 th Brumaire and the accession of the First Consul, Beugnot was summoned by Lucien Bonaparte, who knew him, to serve under the Home Department. He filled a prefecture and was named a Counsellor of State-then an important post in the Government; and upon the creation of the Kingdom of Westphalia he was selected to administer its finances. $\mathrm{He}$ remained, however, but a short time at Cassel, and was soon afterwards sent to Düsseldorf by Napoleon to organise and govern the Grand-Duchy of Berg, which was eventually to be given to the son of the 
King of Holland. In the lottery of crowns which was drawn from month to month by the members and adherents of the Imperial family, it was difficult to foresee in what quarter of Europe a man might serve or reign. The Grand-Duke of Berg of one year became King of Naples the next, and Beugnot, who was waiting at Bayonne to rejoin Murat, suddenly found himself on his way to the Lower Rhine. Ere he started he repaired to the Arch-Chancellor (Cambacérès) for his final instructions, which that distinguished gastronomer delivered in the following terms: "My dear Beugnot, the Emperor settles the crowns as he pleases. All very well. The Grand-Duke of Berg goes to Naples-so much the better. But his Highness was in the habit of sending me two dozen hams from his own duchy every year. The hams I must have. Take your measures accordingly.' The hams were of course punctually sent as long as the stability of the French Empire allowed of it. They were not only to be sent, but sent gratis. Cambacérès had secured an arrangement with Lavalette, the PostmasterGeneral, by which every mail from different parts of the Empire brought a fresh tribute to the ArchChancellor's table, and the fact that he paid nothing 
for them appears to have given additional zest to these varied viands.

Talleyrand held a different language. He referred to what had just taken place at Bayonne in strong terms :- ' Victories,' said he, 'cannot obliterate such actions as these, for they are base, fraudulent, and tricky. I can't tell you what the consequence will be, but you will see that they will never be forgiven him.'

Düsseldorf was at that time the capital of a small state of about a million inhabitants, which had been formed of the principality recently ceded by the House of Bavaria, with some additions from the territory of German mediatised Princes, and the old ecclesiastical domains of Münster. Nothing could be more purely German, and the manner in which these provinces had been torn from their rightful sovereigns to form an appendage to the French Empire was perfectly characteristic of the age. Count Beugnot (for he had accepted that title) compares his own position to that of a Roman proconsul.

It was in those days a position in Europe to be a Frenchman, and a great position to represent the Emperor of the French. Except that I could not with impunity have abused my powers, I was in Germany what the pro-consuls of Rome had been of old. The same respect, the same obedience of the population, the same 
obsequiousness of the nobles, the same desire to win my favour and approval. We were still at that time under the spell of the Peace of Tilsit. The invincibility of the Emperor was unshaken. I came from Paris, where I had spent my life at his Court, that is to say, amidst all the memorable deeds and marvels of his reign. In the Council I had seen that genius at work which ruled the human intelligence. I thought him born to be the true master of Fortune, and nothing appeared to me more natural than that the world should be at his feet. That seemed to me the future destiny of mankind. The country which fell to my lot augmented this illusion. Germany, ever prone to the marvellous, was long in losing her admiration of the Emperor. That admiration was still complete for the hero who had swept away the Prussian monarchy, the armies of Frederick, and the legions of the successors of Peter the Great.

These at least were M. Beugnot's own impressions; but we question whether the sentiments of Germany towards Napoleon in I808 were not embittered by very different emotions. The members of a ruling race are slow to understand, and dull to feel, that hidden hatred which lurks in the heart of a subject people. The French flattered themselves that they were governing Germany, until the warcry of 1813 placed a musket in the hand of every child of that enduring but avenging people. We readily believe that $M$. Beugnot did what he could to render the domination of France endurable to the Germans. He was proud of his little duchy. He embellished and improved the city of Düsseldorf. 
Brought up to the law, he respected the rights of the population; and he had no tinge of that military spirit which was the sorest curse of Imperial France.

I had an honest confidence in the importance and stability of my position; but my character preserved me from the excesses which might have excited the people against me. I love to seek out whatever is honourable and good, and from the bottom of my heart I respected the inhabitants of the Grand-Duchy; but there, as at Cassel, I committed the fault of treating lightly what is serious to the Germans, of seeing everything with French eyes, and, more than all, of giving way to my taste for a joke. This last defect was that which was least forgiven, and I should have succeeded better if I had not given way to it.

But he was compelled by the exigencies of the Cabinet of Paris, with which he corresponded, to drain the country of recruits for the armies of France and of supplies for their maintenance. On all occasions he was made to feel that the welfare of the province was subordinate to the interests of the Imperial Government, and that he formed but a fraction of the immense structure beneath which Napoleon had crushed the liberties of Europe. When that structure began to totter, the governor of the little out-work on the Rhine was one of the first to perceive the altered temper of the German nation, and the eagerness with which, after Essling, they watched every sign of its approaching dissolution. After the battles of Lutzen and Bautzen, 
and during the armistice of Prague, the Emperor himself passed a few days at Mayence and ordered Beugnot to join him there. The account of that interview is extremely graphic.

I found the Emperor as firm and prompt as ever, but he was not at his ease in conversation, and he evidently thought he had a part to play. On the very first day he gave me a long account of his forces of all arms. Whenever he made an assertion in the course of his harangue, which might try my credulity, he watched me closely to observe the effect of his statements. Thus, when he said that the King of Denmark was giving him 40,000 horses, with which he should have the most formidable cavalry in Europe, I made, without intending it, I must confess, a gesture of impatience, from which he inferred that I had no great reliance on his formidable cavalry. He grew angry. "You are one of those wiseacres,' he broke out, 'who are cock-sure of everything. You say, after Frederick, that seven years are required to make a trooper. I tell you, that with good officers, regiments of cavalry are formed as soon as others. Put the men on horseback and they stick there. That is all the secret. Look at my guards of honour! Nothing can surpass them for courage and intelligence. They are admirable cavalry ; have we been seven years forming them?' The conversation turned on the recent levies of Austria and Bavaria. I took the liberty of remarking that they were very strong, and I expressed some doubt of the political views of those Powers. The Emperor pooh-poohed my doubts, but without irritation. I inferred from the manner he spoke of it, that the same idea had more than once crossed his own mind. 'I don't know,' said he, 'against whom these excessive levies of men are intended, by Austria especially. If this goes on, who is to stop? There will be none but women left in Europe to till the ground. I have an army as good as ever, and 400,000 strong. That is enough to right myself in the North. I shall not think of doubling 
it, though nothing would be more easy.' I held my tongue, and acquiesced in everything His Majesty was pleased to wish me to believe. When he thought he had convinced me, he talked of the affairs of the Grand-Duchy. He complained of the local troops, said they cost a great deal, and deserted the next morning. I replied that His Majesty could not expect a parcel of German clodpoles to fight like the élite of the French guards of honour. After some further discussion the Emperor gave up the second light regiment I was to furnish, and said he had rather impose on the country the reorganisation of a good Polish legion which would not desert. I replied that I hoped the expense would not exceed that of the regiment. To which the Emperor replied, ' $I$ ' must have the troops, and formed troops. Manage it as you like. The time for calculating so closely is past.' The Emperor then dictated letters to me for two or three hours, and so many decrees that it would take the whole night to engross them. All this time he was walking up and down in his cabinet, dictating with great rapidity. He stopped a moment at the first word of the sentence, and then threw off the whole in a breath, which rendered it almost impossible to follow him.

The art of the Emperor's secretaries consisted in seizing his meaning as well as they could, retaining if possible any characteristic expression, but putting the whole in their own words. He scarcely read the papers over when they were brought to him to sign, and only complained that they were written with too broad a margin. He insisted on not having any. After some little time Beugnot took an opportunity to urge the Emperor to grant to the inhabitants of the Duchy some relaxation of the state 
monopoly of tobacco, which had been imposed on them by France.

When I had told my story, His Majesty replied, "It is inconceivable that you have not discovered the motive which makes me persist in maintaining the tobacco monopoly in the duchy? It is not the affair of your duchy, but of France. I know very well you gain nothing by it-perhaps you may lose; but what does that signify, if it is to the advantage of France? Know then that in every country in which the sale of tobacco is restricted by the State, and which borders on a country where the sale is free, you must reckon on a continental infiltration by smuggling for seven or eight leagues from the frontier. It is from that I want to protect France: you must prevent this infiltration as you can. I keep it at eight leagues from my frontiers. As matters now are, I can reckon on the returns of the left bank of the Rhine as much as on those of the interior of France. That is what I wanted. Guess then if I am going to sacrifice the interests of France to your convenience.'

Within the next few days the intelligence of the defection of Bavaria and the more than equivocal attitude of Austria reached the Imperial Court. Napoleon said no more of the 40,000 horses from Denmark and of his prodigious reinforcements. But one day when Beugnot, through inadvertence, took his master's chair in the imperial closet, and even took it more than once, Napoleon said to him, in a tone of expostulation rather than anger, 'You will sit in my place, I see; you choose your time ill.' Beugnot had the courage to persist in the represen- 
tations he had already made in favour of the inhabitants of the duchy, and he added that, after all, this was but a small concession to make, in order to give greater security to the rear of the French armies.

'At such a time,' I said, ' the public opinion of a country should be taken into consideration.' 'I understand you,' rejoined the Emperor, looking at me with animation, 'you advise me to make concessions, and to show great respect for public opinion; those are the big phrases of the school to which you belong.' 'Sire, I am of no school but that of the Emperor.' 'That is a way of speaking, nothing more. You are of the school of the idéologues, like Regnault, like Rœderer, Louis, and Fontanes-no, not Fontanes, I am wrong, he belongs to another set of fools. Do you suppose I do not catch your meaning, through all the disguises in which you mask it? You are one of those who sigh for the liberty of the press, the liberty of the tribune, and who believe in the omnipotence of public opinion. Well then ! I will tell you my last word!' Then putting his right hand on the hilt of his sword, he added, 'As long as this sword hangs by my side, and may it long hang there, you shall have none of the liberties you' are sighing for, not even that, Monsieur Beugnot, of making a fine speech of your own in the tribune.' 'But, Sire, what enemy has traduced me to this extent in the eyes of the Emperor?' 'No one; but I know you, and I know you better than you know yourself. You will bring those papers to me at the cabinet this evening.' I was dismissed, but I received the same evening an order to, attend the following day at ten, and to remain at home where I could be found. My audience on the following day was postponed till four, and when I arrived at that hour, I was informed by the Chamberlain of the day that His Majesty was getting into his carriage to leave Mayence.

Before many months had elapsed the sinister pre- 
sentiments of M. Beugnot were fulfilled. Leipzig followed Dresden. The French troops in disorder retraced the great road of Germany which had so often led them to victory. The enemy pressed upon their rear, and very shortly nothing remained for the French Minister who was governing the GrandDuchy of Berg, but to pack up his papers, recross the Rhine, and leave his last dinner to be eaten by the Count de St.-Priest, a French émigré who commanded the division of the Russian army which occupied Düsseldorf.

On the left bank of the Rhine the authority of France was still unshaken, and the Prefect of Aixla-Chapelle could not believe that the allied armies would ever venture to cross that barrier. Six leagues from that city lay Marshal Macdonald at the head of what was called his army. Beugnot was ordered to go to his head-quarters and report on his troops. 'That,' said the Marshal, 'is soon done. The personnel of my army consists of myself, here present, and of the chief of my staff, General Gruneller: as to the materiel, that consists of four straw-chairs and a deal table. This is what they call at Paris the army of Marshal Macdonald.' On his return to Paris with this discouraging report, Beugnot had an audience of the Emperor, who still talked of 
preserving all that he possessed in Germany-his Ioo,000 men on the Elbe-and his determination to fall on the rear of the allies, and if they dared to cross the Rhine- 'vous verriez une belle débâcle.' For the present, however, he ordered Beugnot to proceed to Lille in a position not sensibly differing from that of a prefect. The order was insulting to a man of Beugnot's official rank, and he remonstrated accordingly. The Emperor replied in his usual style :-

'What do you mean? Whosoever serves me must serve as it suits me, and where it suits me. Minister or not, I have not time to think about that, and if I send you anywhere as a sous-préfet your duty is to go.' 'No doubt, Sire, but a man who has filled a high office cannot go to a lesser office without an air of disgrace, for —_.' 'To the point; I am in a hurry. You must go to Lille. Duplantier is killing himself in my service there, which is no good to him or to me either. That department of the North is one of the gates of France, and you will have plenty to do there.' 'The Emperor may rely on my zeal, but may I ask with what title I am to present myself in that department?' 'Really, Monsieur Beugnot, you presume.' 'I beg the Emperor's pardon.' 'Is this a time for titles? Go there as Préfet, as Minister, as Emperor if you dare. How can you talk to me of such nonsense, when my head is on fire from morning till night? Your Macdonald does nothing, prevents nothing. Clouds of Cossacks are ravaging the Rhine departments. I have to organise the defence of the whole country, and with what? At such a moment I place one of the keys of France in your pocket, and you talk to me of titles! It is time enough to talk of that when you have nothing else to do. They told me you were a man of sense, but you don't 
show it. Start at the latest to-morrow morning. Correspond with my ministers, or write to me direct if there is any important reason. Good morning, Count Beugnot, a pleasant journey to you!'

That was Count Beugnot's last conversation with Napoleon Bonaparte. His mission to Lille was of course abortive. All he could do was to prepare the place against a siege by the Russian army, and while he was still at his post he received a note from his old friend Dupont de Nemours in the following terms :-

Take care of yourself. The last barrier is broken down; the Allies will enter Paris to-night or to-morrow.

Nothing remained for the luckless minister but to effect his escape in disguise. At Amiens he saw for the first time the white cockade. At Chantilly the people were cheering the Provisional Government and the House of Bourbon. At St. Denis the Cossacks were burning stacks and collecting forage. And that was the end of the First Empire.

The Emperor Napoleon had not altogether misjudged M. Beugnot, when he told him that he was one of the men who were sighing in their hearts for a more liberal form of government. He had served the Empire, without approving its despotic policy, or abandoning the principles of the Legis-

VOL. I. 
lative Assembly; and he readily lent himself to the establishment of Parliamentary government, when the representatives of the nation first gathered round the throne of Louis XVI. M. de Talleyrand, the sinister genius of the Restoration, was his friend, and accordingly he transferred his allegiance without hesitation to the entresol of the Hôtel St. Florentin, which has witnessed so many of the most remarkable events of this century. ${ }^{1}$ Talleyrand at once placed the Ministry of the Interior in his hands, and he was thus suddenly called upon to take a prominent and decided part in the restoration of Louis XVIII. to the throne.

The task was one of appalling difficulty. The air was infected by the exhalations of dead horses and dead bodies. The enormous supplies of food required for the Allied armies threatened to famish the people. The population was groaning under the horrors of invasion. The roads were blocked by troops or broken up by the recent military operations. Half France was in the hands of the enemy. The whole administrative machinery of the Empire was shattered to pieces. It deserves to

1 The small apartment of the Hôtel St. Florentin was the residence of Prince Talleyrand, and was afterwards occupied by Princess Lieven till her death. The Emperor Alexander of Russia lived, during his residence in Paris, on the first floor of the same hotel. 
be remembered, to the immortal honour of Count Beugnot, that he was the man who, almost alone and unaided, faced these difficulties, and restored something like order in the kingdom. He entered the service of the Bourbons without prejudices or passion; he exercised the power confided to him without resentment; and it would have been well for the Court if they had had the wisdom to confide more implicitly in his patriotism and good sense. His evidence, therefore, on the true character of the First Restoration is of the highest value, and it absolutely contradicts the opinions which have too often been accredited in France.

The enemies of the Bourbons have said and repeated, and they still repeat, that these Princes came back in $\mathrm{I} \mathrm{I}_{4}$ in the baggagewaggons of the invader. So untrue is it that they came in that shameful guise, that the Duke of Wellington refused at Bordeaux to see the Duke of Angoulême, who had thrown himself into that town with more spirit than discretion; and when the magistrates of the town consulted the English general as to the conduct they should adopt towards this prince, the Duke of Wellington replied that he thought it would be unwise to commit themselves with the Duke of Angoulême whilst the Allies were still negotiating at Chatillon with the ministers of Napoleon. At the same time Monsieur (the Comte d'Artois) was timidly approaching some of the towns of Lorraine, more careful to avoid the Austrian commander than the local authorities; he was far enough from invoking the forces of the invader, and he would have done so without success. He had taken refuge at Vesoul, where he was visited by a few gentlemen of the country, and avoided by the greater number. 
The Emperor of Russia declared, in a proclamation of the 3 rst March, that the Allied Sovereigns would only recognise and guarantee a constitution given by the French nation to itself; and, in reply to a deputation of the Senate on the and April, the same prince said, 'It is just and wise to give to France strong and liberal institutions in harmony with the enlightened spirit of the age. The object of my allies and of myself is to protect the liberty of your decisions.' It was only four days later, when the Senate, by its constitution, had recalled Louis Xavier of France to the throne, that the Bourbons were acknowledged. Till then, although France was occupied by 200,000 foreign troops, their existence was hazardous and obscure. And I am confident that if the Senate had at that moment summoned to the throne of France some other family than the Bourbons, that family would have been accepted by Europe, not only without difficulty, but with satisfaction, so generally was the prediction believed that the Bourbons would have great difficulty in maintaining themselves in the country.

M. Beugnot had no previous acquaintance with any members of the Royal Family, and no personal prepossessions in their favour. But the position he filled in the Provisional Government at the moment of the Restoration brought him into contact with the Comte d'Artois, and, in spite of his own liberal views, Beugnot had more personal regard for him than for Louis XVIII. The constant opposition which really existed between these two royal brothers originated in their characters, but it was strengthened by the whole course of their lives. It had divided the emigration at Coblenz : it divided 
the friends of the Restoration at Paris; and, in spite of the superior abilities, tact, and judgment of the King, the most influential member of the Royalist party was his brother.

On the I 2 th of April the Comte d'Artois made his triumphal entry into Paris. That was beyond a doubt the brightest day of the Restoration. The enthusiasm of the people was genuine. The crowds flocking around him arrested his passage from the Barrière de Bondy to Notre-Dame. To some one who attempted to make way for him the Prince exclaimed, 'Laissez, Monsieur, laissez, j'arriverai toujours trop tôt.' On his return to the Tuileries, Beugnot expressed a hope that he was not 'fatigued.' 'Fatigued? How should I be fatigued? This is the only day of happiness I have had for thirty years ...'But, after all, the brilliant impressions of the day were over, and the mighty work was not complete. 'There remains,' said M. de Talleyrand, "the article to be written for the "Moniteur;" and, above all, what had the Prince himself said on so memorable an occasion?' Nobody could recollect. The probability is that, beyond a few incoherent expressions of pleasure and of gratitude, he had said nothing at all. Then it was that Beugnot reached the culminating instant of his life. He tried it once. 
He tried it twice. M. de Talleyrand was not satisfied. At last M. Pasquier gave a fortunate hint, and at the third effort, Beugnot produced (out of his inner consciousness) those memorable words which appeared in the 'Moniteur' the next morning, and have been ascribed to the Prince by an admiring posterity: 'Plus de divisions: la paix et la France: je la revois enfin! et rien n'y est changé, si ce n'est qu'il s'y trouve un Français de plus!' 'Capital,' said the great censor, 'and I give you my word that the Prince will believe in a day or two that he really uttered them, and nobody will recollect you had a hand in the matter.' The bon mot has outlived not only the Prince, but the dynasty; and as M. Beugnot lost the honour of it in his lifetime, it is but fair that it should now be restored to his memory.

The following anecdote of that pedantic priest, the Abbé de Pradt, Archbishop of Malines under the Empire, is so droll that we must make room for it :-

The day the Provisional Government was formed, the Archbishop of Malines called on M. de Talleyrand, and expressed his surprise that so important a structure should have been raised without reserving a place for him in it, and he asked the Prince, with some ill-humour, what it was intended to do for him, as he clearly could not be left out. ' 'Leave you out,' exclaimed the Prince, 'far from. 
it. You can at this moment render a most signal service. Have you got a white pocket-handkerchief?'-'Yes.'-But a very white one !'- 'Certainly.'- 'Let me see it then.' The Archbishop pulls out his handkerchief, Talleyrand takes it by one corner, and waves it frantically in the air, shouting, 'Vive le Roi!' 'You see what I am doing-now take your handkerchief, do as I do-go down along the Boulevard towards the Faubourg St. Antoine, waving the white standard, crying 'Vive le Roi!'- 'But, Prince, you can't mean it. Just look at my dress. I am in my bishop's wig-my cross, my legion of honour.'- ' Just so,' rejoined Talleyrand, ' that is just what is wanted. If you had not got them on, you would have had to fetch them. Cross, wig, powder, dress, all that will make a sensation, and it is a sensation we want.'

It is hardly credible that M. de Pradt, a man not without talent and ability, should have fallen into such a trap. But off he went on Talleyrand's errand. At first he got on pretty well, though he was soon surrounded by a crowd of street blackguards; but when he reached the Boulevard Poissonière, the Archbishop fell upon a knot of Bonapartists, who soon charged him and sent him flying homewards. His flight was so rapid that he had to pocket the white standard and to rush through the mud. In this state he got back to the Rue St. Florentin, where he proceeded to relate with great emphasis his daring and his success. $\mathrm{He}$ had conquered a great part of the capital to the royal cause; he had been stopped at the Faubourg Poissonière by obstacles which could only have yielded to a troop of horse; but he still showed in his retreat that he was alike unmoved by the eye of Bonaparte and by the tumult of the populace, prava jubentium. All which M. de Talleyrand listened to with the utmost coolness, and only said, "I told you that, dressed as you are, you would make a sensation.'

The sketches of the Comte d'Artois and the newborn royalist Court are extremely fresh and divert- 
ing, but we must leave them on one side to preserve a more sober portrait of the King, who shortly afterwards reached his capital. The entry of Louis XVIII. into Paris was less animated than that of his brother. The performance suffered by repetition, and the enthusiasm of the people had begun to evaporate. Above all, the chief actor was not the same. The Comte d'Artois was still the 'gay cavalier' of Versailles, graceful, excitable, and $F$ rench in every gesture. Louis XVIII. was corpulent, infirm, and dignified. When it was proposed to put him on horseback, he contented himself with the remark, 'I tremble for the marshals who would have to support me.' And the sallies he frequently indulged in were more calculated to sting than to soothe those about him.

Louis XVIII. maintained all the dignity of the throne amidst that mob of sovereigns who were then assembled in Paris, escorted by thousands of soldiers. Though he was himself unarmed and well-nigh powerless, he was so full of the superiority of the King of France over all other kings, that even they were persuaded of it. The Emperor of Russia himself accepted it. M. de Talleyrand had failed in an attempt to cause the Duc de Vicence, who was his friend, to be included in the peerage; but as the Emperor Alexander professed a particular regard for this personage, he undertook to ask Louis XVIII. for his advancement. His Imperial Majesty repaired to the Tuileries. The King received him most graciously, but without the least relaxation of his own dignity. Alexander was so taken aback that he did not venture 
to ask for a thing likely to be refused him; he came back as he went, and candidly acknowledged the reason to M. de Talleyrand. Talleyrand told the Emperor that he was the only man in Paris who did not know his own power, and begged he would try again. This time the King had heard of the affair and was on his guard. The Emperor had not a chance. Louis XVIII. began by flattering generalities which melted Alexander, and he then touched on the melancholy position of a sovereign, after a revolution, who was not free either to grant or to refuse his favours. All this was said with such a tone of feeling and truth that the Emperor was again taken in, and left the palace without alluding to the object of his visit. He thought it easier to offer Caulaincourt a great position in Russia than to mention his name to the King of France. In such passages as these the King was really a great master; and I had more than one opportunity of remarking that he was himself thoroughly persuaded that, of all the sovereigns then in Paris, he was the only gentleman.'

Not a year had elapsed since M. Beugnot was writing despatches under the dictation of Napoleon at Mayence. It now became his duty to attend Louis XVIII. as Minister of the Interior, and to take his commands on the urgent questions of the day. A greater contrast has rarely fallen under the observation of a statesman.

I arrived on the 6th May to work with the King. I brought him some important affairs, which Monsieur had not chosen to decide, having heard of his brother's speedy arrival. I had recently had occasion to lay matters of state before Napoleon, and I adopted with the King the same form of proceeding - that is to say, I had all the papers of each case carefully arranged, and I placed a précis before His Majesty stating the name of the parties, 
the nature of the question, its importance, and some observations upon it. I begged the King to look over the précis and tell me which paper he desired to take first. His Majesty, who had never seen or dreamt of anything of the kind, asked me what I meant. I had the maladresse to say that this was the way in which Napoleon transacted business, as he was very much pressed for time, and therefore chose the questions which appeared to be the most important. 'Very well, sir,' said the King, 'but as I shall always have as much time to give you as you may require, you may relinquish these modes of proceeding of Bonaparte. They are not to my taste. Begin at the beginning.'

After this exordium Beugnot had the barbarity to keep his unfortunate master an hour and a half over the papers. 'You have not spared me,' said the restored son of St. Louis. 'This is pretty well for a beginning. However, I shall always be ready to receive you.' And the next day he inquired whether his minister had not been a lawyer, from his love of detail. At length the Abbé Louis came to the rescue.

How came you not to see, on the very first day, my dear colleague, that you bore the King to death? What is the use of making reports to him? You might as well make them to a saint in his niche. I just give him the ordinance to sign; he never refuses; while he is writing his name, which he does very slowly, I tell him what it is about. I don't bore him; but he bores me, because his signature is everlasting.

It is not surprising that a minister taught under 
so rlifferent a school, and so little versed in the temper of the old Court, should soon be told to vacate his office. Beugnot only saw the King six times. Madame de Simiane and the Damas family remarked that the Ministry of the Interior ought to be filled by a man of quality, assisted by what she elegantly termed 'des bouleux,' and the Abbé de Montesquiou was authorised to request $M$. Beugnot to retire from the department. He consented, however, somewhat weakly we think, to act as Director-General of the Police, and he was named by the. King one of the Royal Commissioners charged with the preparation of the Charter.

The chapters of the second volume of these memoirs which record at considerable length the discussions on this important instrument are, for the purposes of history, the most valuable portion of $\mathrm{M}$. Beugnot's reminiscences. But they are already known to the public, and, in particular, they have been largely used by M. Duvergier de Hauranne, in the second volume of his admirable 'History of Parliamentary Government in France.' It would draw us too far from our present object to follow M. Beugnot in this portion of his life-suffice it to observe that the notes of these debates were evidently made at the time, and that they are the 
most authentic record which exists of the origin of the Charter of I 8 i 4 .

We prefer to revert to his personal recollections and adventures during the Hundred Days.

A very short experience of the character of the prince who was thus, by the grace of God, replaced on the throne of France, might have satisfied a man of the world like M. Beugnot, that nothing was to be expected from such a master. But it was a time of illusions, and probably the ambition of playing a more brilliant part under the Constitutional Monarchy than he had done under the Empire, induced M. Beugnot to take too flattering a view of the future and of his own prospects. Upon the return of Napoleon in March I8 15, he accompanied the King to Ghent; he shared the privations and anxieties of the Hundred Days in Flanders, when the Royalists and the Court were once more reduced to an ordinary of half-a-crown a day, and he returned to Paris after Waterloo. Perhaps the disappointment he afterwards felt at the King's faithlessness and ingratitude. may have rendered him severe to Louis XVIII., but M. Beugnot is the only writer of the time, as far as we remember, who places Charles $\mathrm{X}$. in ability. above his brother. 
Those who have never had occasion to transact business with Monsieur are always talking of his want of capacity, his narrow views, and his obstinacy. These reproaches are utterly unfounded. Monsieur applies to business a great deal of intelligence and earnest attention. It must be admitted that he sticks to the principles in which he was brought up; but his attachment to them is based on conviction, not on prejudice, as may easily be perceived from the skill with which he defends them. He is not without dexterity in argument, and readily seizes on any advantageous point of discussion. All this is, moreover, covered with absolute good faith, and no man has a conscience more void or offence.

Few people have said as much for Charles X., and M. Beugnot is evidently speaking the language of personal regard. For Charles X. did undoubtedly inspire the strongest personal regard in those who knew him, whether on the throne or in exile. Louis XVIII., on the contrary, can hardly be said to have had a sincere friend or to have deserved one; for though his attainments, his wit, and his judgment were far beyond those of his brother, his character was one of unmitigated selfishness and extreme duplicity.

After the battle of Waterloo the King lost no time in re-entering his own dominions. He ordered his Ministers to meet him at Cambrai, where a $T e$ Deum was sung in honour of the victory of the Allied armies, and the Court travelled with so much 
rapidity that they had reached the gates of Paris before it was known that they had left Ghent. Fouché alone was in the secret of the King's movements, for that ingenious personage, foreseeing the speedy termination of the Hundred Days, had continued to negotiate with Ghent, while he was still ostensibly serving the Emperor at the Tuileries, and he took care to warn the King that the least delay in his return might be fatal to the dynasty. On the road to Paris Count Beugnot and Count de Jaucourt followed the King in another carriage. As they proceeded on their way, marks of the passage of the invading armies became more frequent, and near the village of Cavilly they passed the cottage of a widow which had been set on fire by some marauders. The poor woman sat on a stone disconsolate to watch the destruction of her little all; her children were sobbing on her knees; and the whole scene was most afflicting. It seemed strange that the King of France in his coach should have passed along the road a few minutes before without taking the slightest notice of such an incident. However his two followers relieved the poor woman and kept their suspicions to themselves, charitably supposing that the King might have been asleep. Arrived at the village where the King was to dine, they 
rejoined His Majesty, and the following conversation ensued :-

'We are happy to see that the King is arrived in safety, but your Majesty cannot fail to have been painfully affected by what we have just witnessed-a house on fire ; it belonged to a poor widow with her two wretched children, and not a soul to help her.'

'Ah, indeed!' said the Monarch; 'I saw the house burning, and remarked that there was no one to put it out.'

$M$. de Jaucourt. 'It had been set on fire by some of the enemy's light troops, and the people of the village fled at their approach.'

The King. 'Something of that kind, I suppose.'

M. de Jaucourt. 'They must have pillaged the country, for we were told just now that there would be a difficulty in providing the King's dinner.'

The King. 'Oh! don't be uneasy. You are not aware, M. de Jaucourt, that the rabbits of this village are the most juicy rabbits in France-in all France. I remernber coming here thirty years ago ; nay, four-and-thirty years, it must have been, with the Marquis de Montesquiou and Chabrillant. The people of the country have a peculiar mode of dressing rabbits. I am to have two of them for dinner, and shall not be ill off . . .

We were far enough from the poor widow and her house on fire, but M. de Jaucourt artfully brought it up again.

' The King is good enough to conceal his own privations, but it is the duty of his servants to share them, for the occurrence I was just speaking of-that fire in the widow's house-is one which will happen elsewhere, and we must all do as much as we are able, for it must everywhere be said that a disaster witnessed by the King is a disaster repaired.'

The King. 'What can be done, gentlemen? It is not my fault. We must do as we did last year. Time and patience will 
set things to rights. I can't ask my Ministers to dine with me to-day ; but I strongly recommend you to take care to taste those rabbits . . . and the gesture of dismissal.

If Talleyrand was the genius of the first Restoration, Fouché was that of the second. It was impossible to avoid a recognition of his servicesperhaps we might say the stipulated reward of them; and as M. Beugnot had performed the office of Secretary of State on the journey, it devolved on him to present to Louis XVIII. for signature at St. Denis the ordinance conferring the office of Minister of Police on the regicide Fouché, now Duke of Otranto. The King signed one or two other papers, and made a joke about the opera.

At that moment I laid before him the nomination of the Duke of Otranto. The King glanced at it and dropped it. His pen fell from his hands. The blood rushed to his face. His eyes assumed a painful expression. For some minutes the silence was unbroken. At last with a deep sigh the King said, 'It must be done, then.' He took up the pen, still hesitating to sign, and added as he wrote, ' $\mathrm{Ah}$ ! my poor brother! if you see what I am doing I am already forgiven.' The tears fell from his eyes upon the paper. I folded up the ordinance and left the room without another word.

After the fidelity he had shown and the services he had rendered in the second exile, M. Beugnot had reason to rely on the assurances he had received of his Sovereign's gratitude and regard. He was 
not, however, included in the ministerial arrangements, and the Ministry of Marine, which had been designed for him, was handed over to his travelling companion, M. de Jaucourt. On this occasion the King offered him the Post Office, with the rank of Minister, adding, 'This position will suit you, for it rescues you from ministerial changes, and you will keep it as long as you retain my personal confidence, -that is, a long while, or rather always.' Not long afterwards M. de Vitrolles reminded His Majesty that the Post Office had been promised to himself, and expressed his regret that Beugnot had not been named to higher functions. 'Have patience,' replied the supple Prince, 'you shall have the Post Office, when I take it away from Beugnot, and that will not be long ...' We care not to track the maze of intermediate intrigue with which the Court was already undermined. It is enough to add that, before many weeks had elapsed, and on the first change of Ministry, the King took occasion to inform Count Beugnot, with evident embarrassment, at his next audience, that another person had just been appointed to the office he filled!

At this point the memoirs abruptly terminate, and we presume that this was Count Beugnot's last experiment in the service of His Majesty King VOL. I. 
Louis XVIII. Nor, indeed, did he again hold office; he sat in the Chamber of Deputies from 1819 . to 1824 , voting generally with the Liberal party ; in 1830 he was raised to the Peerage; and in 1833 he reached the close of his honourable and eventful life. 
MOLLIEN.

A 1 



\section{MOLLIEN. ${ }^{1}$}

THE autobiography of a Chancellor of the Exchequer or a Paymaster-General is a subject not lightly to be approached by ourselves or incautiously imposed on the patience of our readers. We engage then at the outset to pass by the chronology of departed budgets and to forswear the mysteries of double entry. We shall neither linger at the receipt of custom nor perplex our pages with the tableaux of what is termed a 'financial situation '- but, leaving these scrinia sacra, endeavour to draw some attention to the personal history of a statesman who has seldom been surpassed for good sense and integrity, -we mean Count Mollien, formerly Minister of the French Treasury.

The work before us was commenced in 1817 as a record of the actions of a well-spent life, and it includes a large quantity of notes taken at the time

1 This paper was first published in the Quarterly Review, No. 18I, for June 1852 , as a review of the following work :-

Mémoires d'un Ministre du Trésor public. 4 vols. 8vo. Paris : 1845. (Not published.) The work itself has not yet been published. 
from the conversations of Napoleon, besides an extensive selection from his administrative correspondence. A great judge of mankind, who has himself passed alternately through the fascination of the Emperor's genius and the indignities of his resentment, assures us that upon the whole no known memoirs give so accurate a picture of his peculiar qualities and defects in the transaction of civil business. This book still remains unpublished, though completed by its author before his death, and even printed under his directions. It was his will that the work should be considered the private property of his excellent wife during her survivorship, and accordingly it is to the personal courtesy of Countess Mollien that we owe this opportunity of anticipating the judgment of the public on the eminent abilities and the estimable character of her husband.

We have seldom had the good fortune to meet with a more genuine production in this branch of literature; and we mean by that expression not only the indisputable authenticity of the work-a point not always to be overlooked in French memoirsbut the absence of theatrical display, the truthfulness of impressions, the modesty and good faith which pervade this narrative of so many great and strange 
events. M. Mollien brought to the service of his country all the qualities most opposed to the prevailing illusions and excesses of his epoch, and to the showy but ephemeral grandeur of the Government to which he belonged. The world was convulsed by a paroxysm, but nothing could shake his stubborn arithmetic. He lived through a storm of revolution, bankruptcy, violence, and war, with unshaken fidelity to the traditions of authority, with the nicest regard for the obligations of public credit, with an inflexible adherence to right as the sole basis of permanent power, and with undisguised apprehensions as to the result of the Imperial policy. Throughout that eventful era Mollien was always the drab-coloured man, constant at his desk with his pen behind his ear. His sedate remarks and his sinister forebodings, in the midst of so much waste and riot, remind us of the unheeded steward in Hogarth's picture of the Rake's Progress. Nothing could inflame his imagination or subvert his principles and whether shouts of victory or the crash of defeat rolled beneath him, he remained in unshaken composure, until Napoleon himself ejaculated one day in I 8 I4, ' Mon cher, il n'y a plus d'Empire.'

He lived for esteem rather than for renown; and the services he rendered to the Imperial Govern- 
ment were not the less important because they were unostentatious and frequently unavowed. He retained those qualities of personal dignity, and a sense of public duty, to which revolutionary governments are commonly most fatal; and he held extremely cheap that adventurous and haphazard spirit which formed the chief greatness of his contemporaries. For this reason, however, these volumes are deficient in the minuter sketches of private life usually expected from Memoirs. The personal narrative of the writer is reduced to a slender compass, and he only alludes to the principal occurrences of his own career as much as is indispensably necessary to explain his connexion with public events. In a word, he led what is termed a life of business, and even his memoirs are written with as much conscientious labour and precision as a report on the state of the Treasury. 'They deserve, therefore, to rank above the class of personal reminiscences of the Empire to which they might be supposed to belong; and from the remarkable soundness of the economical principles which Count Mollien professed, as well as from his acute analysis of the resources of Napoleon's government, they may form a valuable addition to the libraries of statesmen.

In spite of all that has been said of the state of 
French society before the outbreak of the Revolution, and of the destructive influence which the eighteenth century had already exercised upon the fundamental principles of religion and order, that Revolution undoubtedly found in the prime of life a race of men whose equals France has not produced at any subsequent period-and the generation it sacrificed stands far superior in energy and solid ability, if not in intelligence, to the generation formed after its own image. To that race of men, whose representatives were ere long to sit as sovereigns on the benches of the Tiers, young Mollien belonged. He was the son of a merchant at Rouen, born in I 758, ' in that class of life to which,' as he says, 'I should myself have chosen to belong, since it is neither tormented with envy nor apt to inspire itvoluntarily dependent on the laws, but dependent only on mankind by reciprocal duties.' Having gained some prize at the University of Paris, the reversion of an under clerkship in the Treasury was promised him by a friend of his father; and in the meantime he pursued the study of the law. At this period his father took occasion to address to him some judicious remarks on the receipt of those professional emoluments which secure independence in life, but which Mollien's juvenile delicacy fancied to 
be inconsistent with his own dignity; and the parental admonition was terminated by placing in his hands a copy of Adam Smith's 'Wealth of Nations.'

'Property,' said the old man, ' is a word which I never pronounce without respect, and I confess I have found no work which defines it exactly as I comprehend it. The elder jurists consider it chiefly as an affair of transfer and inheritance; but my notice was lately drawn to an English book, in which I find, though not a special treatise on property, more extended notions of its elements, of the circumstances which affect it, of the ties it establishes amongst men, to whom it affords under so many different forms the sole matter of exchange. I recommend this author to your meditations; he has imagined nothing, but he has observed everything; his theory is exact, not conjectural ; it explains the mechanism of society as Newton explained the solar system-by proving it. Such a book ought to be in the hands of all who take any part in public affairs, and especially of those who direct them. I am an old man, yet I can scarcely name a minister who has studied or who would have applied these principles. Perhaps the writer speaks to his readers in too high a tone, for it is not by contempt that false opinions can be effectually attacked; but as you, my son, are not called upon to enlighten or to govern others, it is for your own guidance that I exhort you to study the doctrines of my English author, whom I regret to find extremely superior to the economists of France. Be prudent enough not to use what you may find in it as a means of censure on our'own Government, but regulate your personal conduct by its maxims.'

This paternal exhortation powerfully contributed to give a lasting direction to young Mollien's life. His mind was thoroughly imbued with the clear fixed

- principles of Adam Smith on subjects then obscure 
to many of the most thinking men in Europe. $\mathrm{He}$ accustomed himself more and more to make the laws and obligations of property the constant subject of his reflections, until they became his rule of conduct and his test of truth. Every question resolved itself at last in his mind into a financial equation; and as, contrary to the prediction of his father, he was called upon to take an important part in the government of the largest empire the world had witnessed since the fall of Rome, he presents the singular anomaly of a French minister under the reign of Bonaparte steadily endeavouring to apply the principles of Adam Smith, as far as he was able to prevail against the prejudices of his time and the passions of his master. Shortly afterwards, having relinquished the practice of the law, partly in consequence of the advice of an elderly advocate who sagaciously predicted the catastrophe already impending over the legal profession, Mollien received a regular appointment under the ferme generale, or financial company then entrusted with the collection of the public revenue.

During the seventeen years which he spent in the labours of this department he passed successively under the orders of no less than fifteen financeministers, and he had remarkable opportunities of 
studying and comprehending that extraordinary and increasing series of financial difficulties which at last brought about the dissolution of the monarchy. Financial burdens of far greater amount are now borne with comparative ease-financial difficulties requiring far stronger remedies are now boldly solved. But the French Treasury under Louis XVI. had fallen into the hands of empirics. The excellent intentions of the King were defeated by the feeble instruments he was compelled to choose. Confidence was destroyed, and the machinery of fiscal administration was incurably old, oppressive, and ineffective. A clandestine warfare was carried on against the fiscal authority deputed to the ferme, for in the single year $1 \% 83$ the contraband of salt was so extensive that 4,000 domiciliary visits had been made, 2,500 men, 2,000 women, 6,600 children, I,200 horses, and 56 vehicles had been arrested on the public roads, 200 convicts were sent to the galleys, and out of the 6,000 forçats then in the bagnes one-third were sentenced as smugglers. M. Necker declared the interest of the debt of France in 1785 to be 207 millions of livres, but that sum increased by 10 millions before the end of the year, and from 1774 to $I 785$ the augmentation in the interest of the debt had been 123 millions. 
'But this funded debt,' says M. Mollien, 'was not the only one which Louis XV. had bequeathed to his successor; it was not so much it, as the unfunded debt, left floating and without security, which was deepening the abyss.' It was in a word the accumulated result of dishonesty and procrastination and of unclosed accounts in every department of the Government. In $1785 \mathrm{M}$. Necker computed this arrear at 250 millions; in 1789 it exceeded 550 ; and the result of these debts-disguised under the name of outstanding accounts-was to render it almost impossible for the State to contract any regular loan except on most onerous conditions. We advert to these figures, which give a brief summary of French finance before the Revolution, because in our own day we are witnessing a repetition of many of the same phenomena-a rapid series of ill-qualified ministers, governing on no financial system, but providing only for the wants of the hour-a huge augmentation of the public stocks, and a still more rapid increase in the floating debt of the nation. These evils became greater under the reign of Napoleon III., after eighty years of revolution, than they were under Louis XVI., at its commencement. They were controlled, and their consequences might have been averted, by the great improvement in 
the system of public accounts and a more equitable adaptation of the incidence of taxation. But it must now be added [1872] that they have ended in an amount of debt and liability infinitely surpassing the puny embarrassments which weighed upon the resources of M. Necker, and were supposed to threaten France with bankruptcy in the year 1789 .

Amongst the men then in Paris whose attention was directed to these subjects, long before it was discovered that the laws of finance involve no mysteries but the steady application of a few fixed principles and plain rules of honesty and good sense, was one whose name deserves to be rescued from oblivion. Under Necker's first administration, a Genevese banker, M. Panchaud, who had resided for some time in England, established a house of business at Paris. His operations were large, and not always profitable, but he produced a greater effect on the world by his salon than by his caisse. He talked on financial subjects with singular eloquence, and attacked the calculations of the Minister of the day with extreme vehemence. Courtiers, abbés, magistrates, and idlers flocked to hear him, and amongst them were to be found one or two men capable of appreciating the value of such lessons. M. Mollien was one of the youngest of his guests, 
and with him young Louis, afterwards abbe and baron, the same who, twenty-five years later, under Louis XVIII., restored the credit of the monarchy after the calamities of 1815 . M. Panchaud had assisted Turgot to organise the first caisse d'escompte established in France, which was the germ of the Bank of France itself, and he was habitually consulted by M. de Calonne. Under the latter of these ministers a question arose about the reissue of the gold coinage. Panchaud was affronted that his opinion had not been asked, and he found means to place before the King a paper, in which he convicted the Minister of an inaccuracy. The King read the paper, and, handing it to Calonne, told him to answer it if he could. Calonne, whether from malice or from unconsciousness, called upon Panchaud himself to supply the refutation, and the unhappy Swiss was compelled to strangle, one by one, his own arguments, lest he should betray his secret and lose his place.

'How little prepared for great events,' says M. Mollien, 'was an Administration so obstinate and immovable in the midst of the light, the wants, and the interests growing from day to day around it!' Mollien himself was at this time only twentyfive yéars of age; yet he was employed to draw up 
the Report of the Minister to the King on the renewal of the leases or contracts with the Fermiers Généraux. The Minister received a present of 300,000 livres, which was the usual gratuitycalled the pot de vin du bail des fermes. Necker had refused on a former occasion to accept it. The merit of the young clerk who had done the work was, however, not altogether overlooked, and he obtained a pension of 3,000 livres from the Crown for extraordinary services-a merited reward, of which the Revolution was ere long to deprive him. That catastrophe already overshadowed the highest institutions of the country and the first interests of the State, not so much from the magnitude of its embarrassments as from the want of intelligence and skill to deal with them. At the outset, by bad public examples, the authority of property was already shaken; and as it was the peculiar characteristic of Mollien's mind to combine every political principle and even the laws of morality with the forms of property with which he was most conversant, the French Revolution is judged by him chiefly from this point of view. Thus he writes :-

Public credit only begins with the respect of Government for every species of private property. M. de Calonne had been led by the force of events to think, as M. Necker did, that a grand 
revolution in the financial system of the kingdom could alone repair its disorder, and he thought himself strong enough to undertake the task. But neither M. Necker, nor M. de Calonne, nor perhaps any one in France had then foreseen that a grand revolution in our finances would infallibly lead to a revolution in our whole social constitution. Some one has said that no Government in Europe could long resist the resentment of violated property. He who made that remark might have foreseen the explosion which M. de Calonne was preparing without intending it.

And thus, in examining the practical character of the legislative body which so soon acquired an absolute and dictatorial power in the kingdom, he says :-

The Assemblies convoked in 1788 and 1789 did not represent the property of the nation. Their majorities represented lifeinterests only, or that floating class of society which has but vanities to defend. They brought on the stage decreasing talents and increasing passions, and the rights of property were lost in the name of equality of rights. The property of France was called upon to support the extravagance of that revolutionary power which, without finances or taxes, raised fifteen armies, and boasted that it had sent $1,500,000$ combatants to the field. By the side of the ruin and universal devastation which the country had thus to endure, the sacrifices necessary to meet the deficit of I 789 would have been small indeed. But, composed as the Constituent Assembly was, it soon showed that it was capable of anything, because it relied on the classes which had no property at all. There are truths which nothing but the instinct of property teaches ; as, for instance, that the seizure of property by an abuse of power is only to legalize armed robbery. . . . Property is the principal organ of the social body. It sets in motion all the rest :

VOL. I.

B B 
but it is also the most irritable and delicate of all institutions, and the slightest lesion on one point throws the whole frame into suspense and peril. It was for this reason that, in common with a few thinking men of the circle of the Duke of Rochefoucauld, I considered the first convocation of the National Assembly to be so fatal ; for we understood by the term property all that human intelligence and foresight can create and permanently appropriate to the preservation of man.

Whilst Mollien continued to watch the progress of the avalanche, without partaking in the illusions of either side, it overtook him in his own career. He had foreseen that Paris would become the least desirable residence in France during such a convulsion ; and he obtained from M. Tarbé, who had just been named Minister of Finance, an appointment to superintend a branch of the Revenue in the department of the Eure. In the provincial society of Evreux he found many at heart unfriendly to the Revolution, in which they seemed to acquiesceshocked by the 2oth of June, I 792-appalled by the Ioth of August-at either stage uncombined and helpless. By-and-by, Rochefoucauld - who had concluded a course of weak subserviency to that pedant of treason and atheism, Condorcet, by a sincere repentance-made an attempt to get up an address in favour of the King after the 2oth of June, and forthwith was assassinated at Gisors. Upon the 
same day Mollien was ordered, as a suspect, to repair to Paris. He lost his place, and hints that, had he been a noble, he should have emigrated; but, with more genuine courage and dignity, he turned cottonspinner. He was one of the first manufacturers who introduced into France the machinery which was at that time so rapidly extending the industrial power of England. In May I 793 Clavière, who was then Minister of Finance, again summoned him to the capital, and hinted that his refusal to take any part in public affairs might at such an hour be regarded as a crime. To Mollien, however, 'the post of honour was a private station;' and he went back from Paris to his spinning-jennies, wondering only to have found the Place Louis XV., which he had fancied to be blasted with some ineffable horror, looking just as he had left it, with its idlers strolling to and fro in the old tranquillity. Who, on returning after some fresh explosion to that arena of public crimes, has not felt with Mollien that the very stones and houses must be conscious of so much blood, until it is made evident, as it was to him, that even the living men in the streets are indifferent to the events of yesterday, and hardly more attentive to those of the morrow? The frightful familiarity of the population with incidents which would rouse 
every feeling of manhood and of shame in more regularly ordered societies, is the result of past revolutions, and the cause of an endless series of them. It is like the egotism of a pestilence or the apathy of a siege, when men dissemble their fear of danger by the suppression or extinction of their natural sympathies. Mollien returned once more to Evreux, but the Reign of Terror had begun. The provinces were infested by spies and informers; his friends were seized around him ; he calmly awaited the same fate-and soon shared it. On the $1^{5}$ th of February, I 794, three Representatives of the People arrived to punish Evreux, as they said, for its attachment to the tyrant Capet, and one of them pointed out to Mollien, as he was carried away under arrest, the spot reserved for national vengeance. Upon his examination, he found that he was accused of taking part in the Duke of Rochefoucauld's Address. His coolness enabled him to parry the first attack of the revolutionary committee-and he was discharged. A few days later, however, he was again arrested, by an order of the Convention, as an accomplice of the Fermiers Géneraux. His papers were seized, and, as the patent of his small annuity was fonnd among them, he was described as a 'pensioner of the tyrant.' Mollien's chief apprehension was that his own 
workmen would rise to rescue him from his captors. Announcing, in the most prosaic form, that he had occasion to be from home for a little while, he gave out work for a fortnight, and, with these precautions, surrendered himself to the ruffians who were to carry him to Paris.

$\mathrm{He}$ arrived in the night, and was at once restored to the society of the thirty-two Fermiers Générauxhis former masters-in the Hôtel des Fermes-their own property - part of which had now been fitted up with bars and gratings.

Innocence itself sleeps ill in prisons, and, though the night was far spent, most of the Fermiers Généraux were still awake. They were employed, with the incorrigible but ingenuous confidence of honest men, in opposing their own exact calculations to the extravagant suppositions of their adversaries. My arrival astonished them. Their first care was to offer me a share in the wretched furniture of the prison-a mattress on the floor and a screen-in which condition I remained till daylight. Nothing could be more painful than the scene around me, and I confess that I could ill sustain it; but the resignation, the patience, and the hopefulness of my companions gave me fresh courage. I learnt from them that their chief enemy was one of their formeremployes, for whom I had myself obtained from them a place of trust, which he had abused by appropriating 200,000 or 300,000 francs by means of forged documents. This man escaped from prison on the roth of August, and, in order to recover possession of the papers affecting his own character, he declared that he had important disclosures to make against the Fermiers Généraux, which would restore hundreds of millions to the public treasury. 
Access was at once given him to the papers he pointed out, and amongst them he found my own correspondence with the office respecting his defalcation. For this reason he had denounced me. My companions had persuaded themselves that, as he had succeeded in his main object with reference to his own crime, he would cease to persecute them. They boasted that they had a complete answer to every charge that could be made against them, and that they could await their trial with safety. After four years of revolution these worthy men were still in this state of ignorance and delusion as to the 'trials' of that time and the violence of political passions: I sought not to shake their confidence, but I could not share it. I felt that as long as power remained in the hands of men necessarily timid, suspicious, and therefore cruel, who could only replenish their treasury by confiscation, the best chance of safety was in the multitude of their victims and the lassitude of their instruments; that to attempt a defence was to accelerate the universal solution by death; and that in so frightful an epidemic the chief resource was not to expose myself to the contagion. With these views, I merely begged those who took any interest in me to leave me to my fate.

Some of the Fermiers Généraux had proposed to sacrifice their fortunes, thinking — with truth - that they were chiefly obnoxious by their wealth; but the proposal was rejected-because its acceptance might have looked like an acknowledgment of injustice in the charges that had been pressed upon them. This, however, led to inquiry as to the amount of property they could have collected. It turned out that these thirty-two Fermiers Généraux, descending from opulent financial families, and who were 
accused of having robbed the State of two or three hundred millions, could scarcely have raised twentytwo millions amongst them, including their entire property of every sort, if their lives could have been saved at that price. It barely amounted to a capital of $27,000 l$. sterling a-piece. Some of them were so reduced as to be obliged to borrow a pittance for their prison meal. Their courage continued unshaken, even when their danger became more palpable; and they defended themselves from every aspersion on their honour with so much ability that the Convention was at last compelled to decree (May 6, I 794) that they had.put the Republic in peril, because some of their agents had been suspected, in I789, of selling damp tobacco. The decree wound up by sending to the Revolutionary Tribunal the members of this 'conspiracy.'

The illustrious Lavoisier was first informed of the edict, and he had the courage to announce it to the rest. All were by this time so detached from life and human affairs that they gave the same answer: 'We had foreseen it-we are prepared.' I never doubted that I should share the fate of the Fermiers Généraux, as I had shared their arrest, and I was not appalled by the aspect of cleath. But I confess I was not equally firm when I thought of the moments which would precede it. From two to four o'clock every day we heard the shouts of the mob insulting the victims as they passed to execution. Full of the horror of such an end, dying on the scaffold amidst the execrations of the populace, I 
will even confess that, in conjunction with another captive, I had procured opium. We confided our secret to Lavoisier, and offered him a share of our poison. With a moral dignity equal to his great attainments, this eminent man rejected the proposal. ' Nous donner la mort,' said he, 'ce serait absoudre les forcenés qui nous y envoient. Pensons à ceux qui nous ont précédés; ne laissons pas un moins bon exemple à ceux qui nous suivent.'

A few minutes later, the Municipality of Paris, escorted by gendarmes, and accompanied by covered vehicles, arrived to consign the prisoners to the tribunal. They were all drawn out before the wicket, and taken by four at a time to each carriage. The turnkeys were all in tears. In about an hour twenty-four of our unfortunate companions had left the prison, the gaoler watching with obvious compassion each departure, whilst the municipal officers were drinking and shouting in his room. I was standing with the eight Fermiers Généraux who remained, for my turn came after them, being the thirty-third on the list, when the gaoler said to me in a low voice, 'Go in-you are not wanted here.' I had only time to cast a glance at those I was leaving, and to see them smile at the hope of my deliverance. The door was shut upon me, and I was in solitude. What a solitude was that of a prison in which I was to survive thirty-two innocent men! I remained in a state of stupor. It was midnight when the gaoler again approached me. He had just returned from the Committee of Public Safety, where he had given his account of the clearance of the prison, but without naming me. He omitted me there, as he had done in the yard of the prison, because the decree only designated the Fermiers Généraux. Some good action, he said, was necessary to console him for so many others. I hardly thanked him, or understood what he said. The next day there was still danger; an inquiry had been made about me. All the following night I heard but one carriage pass, for carriages were rare at that time in Paris. I thought it was coming to the prison, and half unconsciously groped to the door which separated me 
from the sleeping-room of the gaolers. One of them said, 'That is Fouquier Tinville, going to prepare to-morrow's work with Robespierre. He seldom passes so late.' The very name and object of those men increased the gloom of my thoughts. The next morning I knew that my unfortunate comrades were before the tribunal which would pronounce their fate. At two o'clock, on the 8th of May, I hear a voice on the stairs, and the step of gendarmes. Four of them enter the prison, and behind them three other men, whom I scarcely recognized, but who fell fainting into my arms. They were the sole survivors, who had been saved by some lucky accident ; but they had left their fathers and brothers at the foot of the scaffold, and their own agony lasted many hours after they were restored to me. Soon afterwards eighty fresh prisoners were thrust into our small cell, but the same compassionate gaoler removed us to another chamber in the Hôtel des Fermes, though not within the prison-part of it. He even pointed out to us a small door of escape in case of necessity. At the end of July, the day of deliverance approached. We heard the générale beaten, and the conflict of the 9 th Thermidor between the Convention and the Municipality of Paris, headed by Robespierre. On the 28 th of July we knew the result-and on the and of August I was free.

The interval between his escape from the Reign of Terror and his return to office under the First Consul, may be briefly passed over. He relinquished his manufactory. He lost his father. He wound up his small patrimonial fortune. He early discovered in Bonaparte (to him personally unknown) the future master of the distracted and disgusted nation; but as the young general of the Italian campaign betook himself to Egypt in order to leave 
another year for the execution of his political designs, Mollien, with a characteristic difference of taste, found means to visit England by passing through Holland, and studied on the spot what was of most interest to himself, namely, the effects of the suspension of cash payments by the Bank of England in 1797. He travelled alone, with no companion but his old favourite Adam Smith in his pocket, and he relates nothing of the incidents of his journey; but the effect of it was lasting. He formed a just conception of the nature of English credit; he comprehended the doctrine of the Sinking Fund, as far certainly as it was understood by its authors, perhaps rather more deeply. Though thoroughly French in his predilections, M. Mollien early arrived at many of those principles which nearly forty years of peace have gradually applied to the intercourse of the world; and he returned to his country prepared, at least, to combat some of the delusions of its rulers, and to restore that order which the Revolution had entirely effaced from its public accounts.

The state of the finances of France at the close of I 799 was appalling. The customs hardly covered the expense of collection; and the duties on the registration of sales were reduced to the low returns on the transfers of national property. Traffic was stopped 
by an enormous impost, said to be for the repair of the roads, which, however, remained impassable, whilst the fund hardly paid the expenses of collection. The Treasury was exhausted, and the land-tax so illassessed that it absorbed the proceeds of the national domains still in the market. Assignats had been succeeded by all sorts of irregular paper currencyby mortgages converted into scrip under the title of cédules hypothécaires--a scheme, by the way, which was subsequently revived by some of the financial advisers of Napoleon III. ; by bills or drafts, with no fixed dates of payment, on the public purse; and by other forms of accommodation, which passed at from 50 to 80 per cent. discount on the market, but which the Treasury issued at par, having nothing else to give. The funded debt had undergone a regular bankruptcy to the amount of eighty millions sterling by the reduction of the capital and interest on the national debt from Ioo to $33 \frac{1}{3}$. Yet, in a few months after the establishment of the Consulate, the new Finance Minister, Gaudin, had restored something like regularity to this shattered system. Gaudin applied at once to Mollien to assist him; for they had both served in the Treasury, though in different departments, before the Revolution. Under his auspices Mollien again entered the public service, 
and shortly afterwards he attracted the personal notice of the First Consul, who becomes from that moment the prime subject of these reminiscences.

The career of Napoleon has been described in fifty histories and a hundred memoirs; but Mollien has drawn his portrait neither in the imperial robes nor in military uniform. The object of these volumes is to preserve a minute and accurate record of his administrative faculties, especially in Mollien's own department, and to show with what an amazing combination of versatile talent and solid industry the French Empire was constructed and governed by Napoleon :-

Everything in that vast structure was his own; he was the pivot on which the whole revolved; every act of his life, every line from his pen, betrayed his incessant vigilance lest one iota of power should escape him. His attention was ever ready to turn from the grandest enterprises and the highest interests of the State to the smallest details of administration or police, and to the most minute calculations on the outlay of a parish vestry or even of a family in which he took an interest. He had an insatiable desire to be the centre of everything-the sole principle of motion and activity throughout his dominions. Such an organisation as his was will probably not soon occur in any other man; but what is still more certain is, that, if Napoleon were now to rise entire from his tomb, he would not succeed in repeating his reign.

Il ne parviendrait pas à se recommencer is a significant warning to those who allowed themselves to 
imagine that, in order to renew the Empire, it is enough to dispose of the force of an army and the illusions of the common people, and on such grounds to hope for a permanent sway, in the absence alike of genius-of glory-and of Molliens. The fate of the Second Empire was already written in the failure of the First.

The first appointment which Mollien held under the Consular Government was that of manager of the Caisse d'Amortissement-a fund destined to buy up, at the current price, a certain amount of rentes. In the eyes of the public this post was a species of comptrollership of the funds, which enabled its lucky possessor to make honnêtement the largest fortune in France. In the eyes of Mollien himself it was, as the result showed, an imperfect and inadequate contrivance;-though, as the five per cents. were then at 30 , the State seemed to make an excellent investment in buying up its own securities at that price, he perceived the short-sightedness of its speculating on the depreciation of its own engagements. But to the First Consul the Caisse d'Amortissement represented his own power over the Exchange, and it was the instrument of a puerile illusion, which he inflexibly retained - that a Government ought always to be prepared, by artificial means, 
to support the price of the funds, or, as it is termed in 'Change Alley, to 'rig the market.' The following detail of what took place on Mollien's first interview with Bonaparte, exhibits alike his already imperial presumption and the superficiality of his acquaintance with these subjects :-

He had requested Consul Lebrun to conduct me to Malmaison. I received the command with some nervousness, which, however, entirely left me (though not from increased confidence in myself) when I found myself in the presence of this imposing personage. The conversation lasted two hours, in the presence of Cambacérès and Lebrun, who said nothing. I wrote down what had passed on my return home in the evening of the same day.

The First Consul began by telling me that his intention in establishing the Caisse d'Amortissement had been to make it the comptroller of the prices of the public securities.-I replied, ' General, if the five per cents. which were at ro fr. about twenty months ago are now between 40 and 50 fr., it is certainly not to the Caisse d'Amortissement that this improvement is due.'-'But has not the change in the last fifteen months led to a general hope of progressive amelioration in the country, and is not this progress the interest of every good citizen ?'- 'General, every speculator, on the Exchange and elsewhere, seems to me to follow his natural instinct in buying as cheap as he can when he has to buy, and in selling as dear as he can when he has to sell.'-'But is it not evident that those who speculate on the fall show very little confidence in my government?' - Allow me to ask, Sir, whether any one can always speculate on the fall, and whether it is not an essential condition of all such bargains to be alternately seller and buyer, so that everyone speculates on the rise when he sells, and on the fall when he buys?'- ' But under a Government which desires only the glory and prosperity of the country, as the 
rise in the public funds must naturally be progressive, there ought to be no speculation on the fall. Am I not to regard as disaffected persons men who, to lower the public funds, offer to sell large amounts of them at a price below the current price of the day, and men, I am told, who could not pay the whole price of the stock they profess to hold? Is not this to announce that personally they have no faith in the Government ; and is not the Government to regard as its enemy whosoever declares himself to be so?' - No doubt he who makes this calculation has formed an unfavourable opinion of some particular measure or event; but the occurrence of such an event is not altered because he speculates upon it. If he is wrong, he loses the difference; if he is right, his foresight may not be without advantage to the Government itself. Such a man is in the position of one who in a gaming-house bets on the respective players without playing himself : such bets have no influence on the result of the game.'-'You suppose, then,' said the First Consul, 'that the Government should do nothing to support its credit, and therefore that the establishment you direct is a useless one.'-' It is always honourable to a Government to buy up its debts, provided it be done on public and equitable principles, as a merchant may pay his bills before they are due.''I see the bearing of your comparison. You might also compare the recent state of the finances with what I have made them. All the mischief is not yet cured; but it will be the sooner cured the less criticism and opposition the Government meets with. I know what takes place on the Bourse of Paris; and I judge men by their acts. I don't say they preach revolt there, but they give a wrong direction to public opinion, if not from party spirit, at least from some motive which is less creditable and not less dangerous. To have public opinion well directed the Government must give the impulse, and that impulse must be everywhere the same. . . . Since you acknowledge that it is important to the character of a Government that the price of the funds should steadily advance, the natural consequence of your admission is the right of police 
surveillance over those who, speculating on the variations of the market, are often interested in depressing it. The great order which governs the world ought to govern every part of the world : government is the central power of society, like the sun; other institutions must gravitate in their orbits round it. The Government must therefore regulate their combinations, so that all concur in the inaintenance of harmony. In the system of the world nothing is left to chance; in the system of society nothing must be left to individual caprice. I do not mean to interfere with any man's profession; but, as head of the present Government of France, I ought not to tolerate this profession of stock-brokers, to whom nothing is sacred, and who for a trifling profit would sell the secrets and the honour of the Government itself if they were in their power.'

We spare our readers Mollien's sensible but somewhat prolix reply to these egregious fallacies, in which the notions of the First Consul on mercantile transactions are obviously subservient to his theory of absolute government. Mollien does not appear, however, to have made the most obvious as well as the most decisive answer-namely, that any means taken to force up the course of the funds artificially must eventually depress them, and that Government interference to prevent sales at low prices would shake public credit, because one essential element in such securities is their constant convertibility. In fact, like most of Napoleon's resources of government, he was content to take a falsehood and a sham for reality, and he expected the world to do the 
same. To prevent the natural rise and fall of the funds is to fix the political weather-glass at 'set fair' - that is, to destroy the value of the instrument in order to make it an instrument of deception.

The conversation was broken off by the arrival of some despatches from Russia; but Mollien was desired to remain and dine. The party was small, and the First Consul affected for a while to talk on indifferent topics; but about the middle of the dinner he touched on the questions of the morning, and brought out as his own some of the remarks Mollien himself had made just before-adding that it was absurd to prohibit what they had not the power to prevent, and that the Caisse d'Amortissement deserved to be increased and supported. Mollien was not insensible to this flattering proof of his growing influence, and he was struck with the singular alliance formed in the person of Bonaparte between the desire to command and the desire to please. On the main subject of this discussion, however, Napoleon was incorrigible. The price of the funds was a matter of as much personal vanity and solicitude to him as any part even of his own military administration. At a subsequent period of his reign, after Tilsit, the five per cents. had risen to 90. In 1808 , the Spanish war lowered them to 80, VOL. I.

C C 
and they were still falling, when he resolved, at any cost, to support the market at that price. In spite of the numerous demands on the Treasury at that time, thirty millions of francs were spent in this absurd attempt. The following letter to Mollien on the subject is curious. It is dated from Madrid, $15^{\text {th }}$ of December, I808:-

I see with pleasure that the five per cents. have not been below 8o. I don't regret the thirty millions spent for this object; and if it cost as much more, I desire you to take care to keep up that price. The bank can take a large slice of these rentes, and the Caisse d'Amortissement can take more. They will get $6 \frac{1}{2}$ per cent. for their money. It is only by this means that the five per cents. can acquire value. Every man will know what he has in his pocket when he has no reason to fear that the five per cents. will fall below 8o. I will hear of no excuse. Don't let the five per cents, fall below 80.

Sur ce, je prie Dieu qu'il vous prenne en sa sainte garde.NAPOLÉN.

The same efforts had been made at the time of the rupture of the Peace of Amiens. The First Consul had evidently never considered that treaty as anything more than an attempt to convince Europe of his pacific intentions and his ability for civil government. But he was soon alarmed by the imprudent activity of French commercial enterprise abroad; he insinuated to Mollien that French merchants might insure their cargoes in English 
insurance offices; foreseeing, in his own mind, that the return voyage was by no means secure. Mollien immediately detected the impending rupture, from these guarded remarks; and his conviction was strengthened by the anxiety of Bonaparte to support the funds in the event of some panic which he did not describe. It was partly from the fear of a commercial crisis ensuing upon a fresh declaration of war that Mollien was ordered to revise the statutes of the Bank of France, which had been founded in I800, and to place the credit of that establishment on the most secure basis. Nothing can be more masterly than the papers drawn up by Mollien on this subject; and to his lasting honour it must be recorded that the Bank of France has weathered the storms of more than half a century by a strict adherence to those principles, and that it has displayed a strength and soundness of constitution unapproached by any other establishment in the country. Its system of accounts, likewise introduced by Mollien, is admirable ; for through all the vicissitudes of the Empire, of invasion, and of several successive revolutions, the Bank is every day able to ascertain with precision its real situation; and no undertaking of this nature has till now been conducted with greater ability and success. Even in 
the tremendous convulsions of a victorious invasion, a siege of Paris, and the insurrection of $187 \mathrm{I}$, accompanied by a return to a forced paper currency [1.872], the Bank of France has retained its position and still merits the confidence of the country. It is curious that this excellent system was established under the immediate pressure caused by the rupture of the Peace of Amiens, and was specially intended to assist the interests of trade under that calamity. Napoleon endeavoured at the same time to keep up the funds, and for three days Mollien was ordered to hold the market at the cost of four million francs a-day, which the Treasury could ill spare. But so feeble a barrier was wholly insufficient. The funds fell ten per cent., and Napoleon acknowledged that he was beaten, but boasted that he had done what he could for trade. In truth, he had done nothing at all; and the money sacrificed, in spite of Mollien's remonstrances, went into the pockets of the very class of speculators whom Napoleon abhorred.

The period here described was that when the promises of the Consulate were transformed into the pageantry of the Empire. A mock Court rose upon the scene of the Revolution, and the society of Paris, so roughly dispersed ten years before, 
began to re-assemble. France was once more a monarchy. We have since witnessed a similar transformation-but whilst the piece is the same, the whole quality of the actors is different. Mollien's picture of Paris in 1804 , though not extremely favourable to the new social elements the Revolution had thrown to the surface, might pass for a bitter satire of the state of official society in the capital of 1852 and the scandalous history of the Second Empire; for, amidst all its heinous sins, the despotism of the uncle repressed every irregular passion with severity and punished every abuse of trust-that of the nephew set an example of cynical indifference to public integrity and public decorum.

In spite, however, of the progress already made by the country, the state of its finances had seldom been more deplorable than at the outset of the second period of the war. In the years from $\mathrm{I} 803$ to 1805 the navy had cost 440 millions instead of 2IO; and the war department, estimated at 630 millions, had risen to 809 , leaving many debts still unpaid.

The Treasury was literally exhausted, when, after two years spent in ruinous preparations for war without any result between France and her insular rival, two Continental Powers of the first order 
marched against us and threatened the most accessible part of our frontiers. Such was this exhaustion of the Treasury that Napoleon was only able to form what he called the chest of his grande armée out of a few millions of his personal savings. The contractors, whose accounts were all in arrear, raised their terms as they found themselves more necessary to the Government. To provide the means of moving an army of 100,000 men from the coast of Picardy to the heart of Bavaria, it had been necessary to assist the principal contractors, who, for want of any other means, had taken ro millions of national domains in part payment. The Bank was assailed with demands for the reimbursement of its notes, because it had discounted too freely, and had been drawn on by the bankers who, under the name of faiseurs de service, assisted its operations. All the symptoms of a speedy and terrible crisis were perceptible before Napoleon started for Germany.

M. de Marbois, then Minister of the Treasury, had doubtless perceived the evil; and Napoleon was still more aware of it, but he saw and sought no remedy but in victory. I remember that a short time before his departure, seeing me on his way to the theatre at St. Cloud, he came up and said, 'The finances go on ill-the Bank is in distress. It is not here that I can set things to rights.' That same night he started to join the army. I understood but too well the meaning of those words. I saw that his fate and that of France was again to be risked upon the fortune of war, and I considered with alarm what might be the consequences of defeat, or even of tardy success.

After Napoleon's departure, the difficulties of the Bank increased, and the Council of Regency was constantly occupied with means of dispersing the crowd which demanded payment of its notes. No complete suspension took place, but the payment went on so slowly that public confidence was shaken; 
the notes ceased to circulate freely, and fell to ro discount. Mollien firmly defended the sound principles of banking, with which he alone seemed conversant. But, in reply to his observations, the Cabinet resolved to disperse the claimants by force, as seditious groups, and to pay a small portion of . the notes every day at each of the mairies. No attempt was made to procure bullion from abroad, and the crisis had been becoming every day more formidable, when it was terminated by the battle of Austerlitz, which restored confidence to the nation and enabled the Bank to resume its regular payments.

But though the immediate danger appeared to be averted, Mollien was not to be imposed upon by the assistance which military triumphs can render to financial affairs; and in his view, these victories attacked the fundamental principles of public prosperity, because they attacked the property of nations. If Austerlitz was won Trafalgar was lost; and whilst the French standard floated on the towers of Vienna, the ports of France were closed against all commercial intercourse on both her seas. The troops brought back glory, but left undying resentment behind them. For whilst their chief had adopted and improved the most modern combinations of 
strategy, he retained the rudest notions of antiquity ou the rights of conquest. The armies he led were the armies of a Revolution which had declared war to all property at home and to all governments abroad; and he never learnt in that school the slightest respect for either the sovereigns or the nations he combated. He fancied that Paris could be enriched like Rome, by the tributes of every other people, and that he could thus weaken the power and influence of the princes who were compelled to buy his contemptuous forbearance. But eighteen centuries had elapsed since Rome had subdued the world by a policy which rendered her hostility so terrible and her alliance so onerous. The wealth of those days consisted in the treasures of barbaric kings, and the loss of that wealth was ruin to their dreams of defence and independence. In our times the exchange of mutual services conduces far more to the happiness and greatness of a State than the ravages of mutual destruction. The exploits of violence are superseded by the law of duration, for preservation and increase are the moral law of the civilised world. In the midst, therefore, of the enthusiasm which the great achievements of $\mathrm{Na}$ poleon kindled in the pride of France, those who were disposed to investigate the real benefits of so 
much victory and glory were wont to reflect that whole nations could not be chafed with impunity in their property and their honour, and that it was dangerous to give a national character to the sting of defeat. Already they discerned the gigantic plan of the French Empire, whose grandeur did not disguise its danger. The marvellous man who had risen so rapidly to the highest degree of power, and terminated the convulsions of the French Revolution, had transferred its violence and instability to the thrones of Europe. Yet these critics were not hostile to the new Government-they desired its duration, and they served its interests-for such were the opinions Mollien himself entertained; and it is a remarkable circumstance that in the heart of the Imperial Government such views were deliberately formed.

On the 26th January, I 806, Napoleon returned to Paris in the night. Scarcely allowing his ministers time to congratulate him on the result of the campaign, he summoned a Council of Finance for eight o'clock the next morning. 'We have more serious things,' said he, 'to talk about. It seems the chief interests of the State were not in Austria. Let us hear the report of the Treasury.' The crisis was indeed extraordinary. Pressed by increasing em- 
barrassments, M. Barbé Marbois, then Minister of the Treasury, had been reduced to accept terms offered by a company which had been formed to take the chief military and naval contracts, and at the head of which was the notorious Ouvrard. This company had agreed to discount Treasury bills at 9 instead of 12 per cent.; but, as the demands of the State continually augmented, it had entered into a convention with the Court of Madrid for all the gold and silver which the war caused to be retained in Mexico. The Spanish Government had handed over to them upwards of 100 millions of francs in bills payable in the American colonies, and they had substituted some of these bills of the Madricl Treasury on Havana and Vera Cruz for the bonds of French receveurs generaux which they held. Some advances had also been made to Spain in cash, and the French minister found himself obliged to support the credit of Ouvrard's company to avoid a crash that would have aggravated the position of the Bank. At this point in the report Napoleon broke forth-

'They have deceived you. They have imposed on your integrity, which I don't question. These men who have promised you the treasures of Mexico, how have they more power or skill than the ministers of Spain to cross the sea which is in the hands of the English ? They have gained the confidence of Spain by making over to them funds subtracted from the Treasury of France. 
It is we who are subsidizing Spain instead of drawing from her what she owes us. But the plot is divulged; let us interrogate in person its authors.'

The order was given to introduce the two faiseurs de service, or managers of the company-also the clerk in the Treasury who had been specially entrusted with this negotiation, and who, by the way, had received a million as a gratuity, which he was afterwards compelled to refund. They entered, but the scene which ensued is beyond my powers of description. It was a thunderstorm falling for an hour on those three unsheltered heads. The first of them burst into tears. The Treasury clerk stammered forth excuses. The third, Ouvrard himself, stood like a rock, without uttering a syllable; but his attitude seemed to say that nothing is more transient than a tempest, and that it must be endured. None of them could be much more impatient for the end of it than I was.

The deficiency caused by Ouvrard's operations was estimated by the Minister at 70 millions; it amounted in reality to twice that sum. M. Barbé Marbois was dismissed, and Napoleon insisted on Mollien's accepting that same day the office of Minister of the Treasury. It may here be added, that the very first duty he had to perform was to compel Ouvrard and his accomplices to disgorge their booty. The Court of Spain acknowledged 60 millions of the debt, and of the remaining 82 millions a large portion was obtained by the seizure of their private property, of their stores of all kinds, and by cancelling the debts due to them by the State. It is a singular circumstance that, by interesting two great 
houses in London and Amsterdam in the recovery of the Spanish bills on Mexico, piastres to the amount of three-fifths of the debt were embarked at Vera Cruz on board an English frigate, and brought to Europe in reality for the French exchequer. Mollien was entirely free from the vulgar prejudice so common in his time, and not wholly eradicated in our own, as to the scarcity of bullion being the cause of the embarrassments of the Treasury. His predecessor had been duped by the idea of bringing over new piastres from Mexico, for it was in those days an article of commercial faith that pressure on the money-market arose altogether from the want of the precious metals which the war imprisoned in the Mexican ports. In the eyes of the new PaymasterGeneral the credit of the State depended far more on the moderation, good faith, and punctuality of the Government than on a casual importation of the precious metals.

Contrary to the opinion of his ministers, Napoleon persisted in dividing the functions of the Treasury, which are usually held to be inseparable. By the system he had established, Gaudin (Duc de Gaëte), as Minister of Finance, was charged with all that related to raising the revenue; and Mollien, as Minister of the Treasury, with all that related to 
spending it. Fortunately these two men were united by old friendship as well as community of opinions, and they continued for nine years to act with close and unbroken harmony, which could alone have rendered such an arrangement practicable. Mollien's immediate task was a heavy one. He found drafts on the ministerial departments to the amount of nearly 30 millions on which payment had been postponed. The pay of the army then in France was about I 5 millions in arrear, and the deficit of the last five years was Ioo millions-all this besides the frightful gap caused by Ouvrard's bankruptcy: in fine, some 200 millions were required to enable the Treasury to pay its way. But the manner in which the public accounts were kept was still more extraordinary. The first cashier of the Treasury, through whose hands these transactions with the faiseurs de service had passed, did not suspect the existence of this enormous debt, and Mollien had to place the whole system of accounts on a new footing. We cannot ask our readers to accompany us through the technical detail of his operations; but in this respect these volumes constitute, we are satisfied, one of the most masterly expositions of financial administration to be found in any language. His measures may be judged of by 
their results. Before the end of 1806 the funds had again risen from 56 to 64 ; the rate of discount had fallen from $\mathrm{I} 2$ per cent. to 6 or 7 ; the arrears in every department were paid off; arrangements were made to extinguish the deficit of preceding years; and the Treasury resumed a more regular position without making any encroachment on its future resources. These successful measures were not, indeed, due to Mollien alone, though we suspect that his modesty assigns to Napoleon a larger share of merit in them than the Emperor really deserved. For throughout the copious correspondence quoted and analysed, we hardly find an instance in which the views of the Sovereign were not gradually modified and corrected by the good sense and scientific accuracy of his Minister, and in most of these discussions the Emperor seems to have allied egregious ignorance to extreme presumption.

It would indeed have been difficult for any of the ministers of Napoleon not to communicate their plans to him, which were always minutely discussed before they received his final sanction; for though he left to them the choice of means of execution, he chose that every improvement should seem to be his own work. His sudden elevation rendered it a matter of policy with him to delegate as little as possible of his public authority, so as to remain always and everywhere the man of necessity. Napoleon carried on long and divers correspondences. If they were all collected it would be incredible that any single man could have 
sufficed to do so much; and in each of them he proved that he entered into every subject and every circumstance as if he had nothing else to think of, adapting all rules and principles to his own paramount interest in forcing the most opposite elements to combine in his system. But in these correspondences none proves more thoroughly the patience with which he investigated the most arid details than that which he carried on with myself. It is perhaps the most singular polémique de chiffres that ever existed. I frequently in the early period of my ministry received letters of many pages, solely intended to analyse long calculations, to investigate statements, to divide statistics, and to present the same results under other forms. The principal object of these discussions was to keep all his chief servants in perpetual distrust of themselves and of their subordinates : he had no longer to dispute the superiority of power, but he disputed with everyone the superiority of attainments.

It may be well to cite briefly a few specimens of these letters, despatched in a single day, just before the Prussian campaign :-

I send you the documents relating to the loan for the kingdom of Naples. I have informed you for what purpose this loan is to be made. It deserves consideration. (St. Cloud, r gth Sept., I806.)

Eight hundred thousand francs are wanted at St. Domingo. Contrive to send them, so that this sum may be realised in the colony. (igth Sept., i 806.)

I place extraordinary funds at the disposal of the Minister at War, for the most pressing services of his department on the frontier of Germany. (igth Sept., r806.)

I have read your report. My intention is not to diminish the army of Italy at this time. Send them I,500,000 frs., not immediately wanted in the Treasury of Piedmont, and let me know if the operation will cost anything. (Igth Sept., I806.) 
Explain to me the accounts of the paymaster of the forces in Italy on the contributions raised during the last war on the frontiers of the Austrian provinces. They are stated at I,700,000; they were more. The expenses are not classed. I find an item, 'military subsistence, 3,440,000 frs.' I don't understand this manner of reckoning our estimates. This sum must be divided amongst the bakers, the meat, the forage, \&c. (I9th Sept., 1806.)

Give orders to send 500,000 frs. in gold to the army of Naples; to be charged to the account of its pay. (I9th Sept., r8o6.)

Nor was this astonishing fecundity of details at all arrested by the operations of active war. The battle of Jena was fought on the I4th of October, I 806 ; on the $25^{\text {th }}$ Napoleon was at Potsdam, and continued his correspondence :-

The Prince de Neufchâtel has sent for $2,000,000$ frs. from the military chest at Mayence, to use them as they may be wanted. If there be only $I, 500,000$ frs. still at Mayence, that is not enough - I5,000,000 à la bonne heure; take your measures so as to have always four months' pay of my army in cash at Mayence. (Potsdam, 25th Oct., 1806.)

Send 500.000 frs. in gold to the army of Naples; you can take it from the reserve at Turin. (Potsdam, 25th Oct., 1806.)

I am told the allowances of the Guard are not paid. Send for Colonel Arrighi and pay instantly what is due to the two regiments of fusiliers and dragoons which are to join me. (Berlin, and Nov., r806.)

You state that $25,000,000$ frs. from the sale of cuttings in the woods, which are included in the budget of 1806 , will not be realised till 1807 . Take the money on bills from the receveurs généraux out of the fund of foreign contributions for 1806, which can spare it in cash or in short bills. The public Treasury will 
pay interest to the fund at the rate of $\frac{1}{2}$ per cent. per mensem. (Berlin, 4th Nov., r806.)

Here we are at the 15 th of November. Send me the schedule of remittances to the several departments of the ministry for next month : and tell me how we stand with Spain, and the piastres she owes. (Berlin, r4th Nov., 1806.)

I desire you to keep $7,000,000$ or $8,000,000$ frs. at Strasburg, and eight months' pay for the army, at the rate of 3,000,000 a month, always at Mayence, in cash, as a sacred deposit : then, whatever happens, I may consider my army paid. Otherwise, if another event occurred like Ouvrard's affair last year, or any disaster happened to render bills less negotiable, the pay of the army might be compromised. However, as I am master of Prussia and of all Westphalia, I shall get in some money, and there is no longer cause for uneasiness. (Berlin, I6th Nov., r806.)

The delay in the Spanish payments is very alarming: let me know if they have done anything since the 29 th of October. (Berlin, 24th Nov, r806.)

The same day a long letter directing the form in which the budgets of the Empire are to be drawn up :-

Any treaty which will facilitate the recovery of the piastres is to be accepted. I don't want to trade, but only to get back our own money. I authorise you to conclude any treaty for this purpose. (Posen, 6th Dec. I806.)

The English threaten to confiscate the funds of French holders of British securities. Could we not take precautions to prevent transfers from our securities to theirs? This is a very delicate matter. I do not choose to set the example, but if the English do it, I must retaliate. (Posen, $\mathrm{I}_{5}$ th Dec. $\mathrm{r} 806$. )

$$
\text { VOL. I. D D }
$$


To this last intimation Mollien replied that he did not believe it, because it was contrary to the policy of England; but that he should be delighted if England committed such a blunder, which France might render more injurious to her by refusing to do the same. He fortified this opinion by sending to Napoleon the wise and able paper by the American minister, Hamilton, which demonstrates that policy and morality not only forbid a Government to confiscate property lent to it by the subjects of a hostile Power, but even to suspend the payment of interest on it: and Napoleon dropped the subject.

It was about this time that Mollien undertook the complete reform of the mechanism of the public accounts, and founded the Cour des Comptes, whose methodical operations have continued ever since to control the whole expenditure of France. But the complexity of the accounts of the French Empire far exceeded that of any State that ever existed. It extended at that time from Illyria to Spain, and from Naples to Hamburg. It had to provide for armies on the Tagus, in Calabria, and on the Niemen. It supplied the pensions of the Imperial family and the allowances to vassal kings; for, after the treaty of Bayonne, even the Spanish Bourbons were dependent on it for support; and Napoleon basely evaded 
the payment of the income he had himself allotted to Charles IV. and his family when he robbed them of the throne. It had to regulate the public debt of recently annexed countries, which sometimes became, as in Holland, a matter of extreme difficulty. As the embarrassments caused by this enormous extension of power and military occupation increased, the labours of the Treasury became more onerous. The Spanish war had cost at the end of i 8 Io nearly $220,000,000$ frs., including the cost of magazines and equipments of the army: the mere transmission of the necessary funds under convoy to the different corps d'armée in the Peninsula, where they were continually liable to be cut off by guerillas, became a task of immense difficulty; and, with singular absurdity, Napoleon ordered that 200,000 francs should be dispatched every month from Bayonne in copper money, not reflecting that such a sum would amount to several tons of metal, to be carried over tracks impassable for carriages.

Meanwhile the Continental system, intended by Napoleon to complete the ruin of England, weighed with far greater severity on France and on her tributaries throughout Europe than it did on ourselves, Mollien never countenanced the harsh 
measures which that detestable invention rendered necessary ; and he early perceived its suicidal folly :-

Throughout Europe the most violent complaints were excited by the injury inflicted on all the rights of industry-for industry has become in our time a second property, more intelligent, more active, and more sensitive than the former one. French manufactures were crushed by the aggravated rigour of the prohibitive system. England no doubt suffered also, but she remained mistress of the ocean--she commanded all raw material at a low price, and she levied a tax on the raw material she allowed the Continental consumer to receive. Heligoland, Jersey, Sardinia, Sicily, Malta, and Spain were filled with her contraband traders; for England made war in the spirit of modern improvement; Napoleon in the spirit of antiquity : and there are times at which an anachronism is a mortal error. Twenty thousand douaniers on the frontiers of the empire had to defend the territory against one hundred thousand smugglers, more active than themselves, and more favoured by the population; so that the chances in favour of the contraband trade were as 80 to 20 . Nay, the Emperor had himself increased the evil by his additional duties of 30,40 , or $5^{\circ}$ per cent. on colonial produce, from which even the American vessels were not exempted. Hence the price of colonial produce was sometimes quadrupled, and the taxes of the French customhouse were an additional premium on the monopoly of England. The increase in the prices of raw material, and the want of improvement in machinery, discouraged the manufacturing interest. The export trade in French commodities had fallen off by one-half since 1810 , and prices had also fallen 50 per cent. Napoleon himself seemed at length to acknowledge that commercial interests had a power with which it was necessary to come to terms. He would not recede ; that was contrary to his nature. He did not despair of reducing British trade, he said, in a few months to its last shilling; but he endeavoured to impose on the French 
traders as he had imposed on himself, and it was by pecuniary advances from the Government that he attempted to purchase their silence, imagining that a few loans would satisfy their wants.

His first scheme had been to compel the Bank of France to advance money on the bills of all traders, reputed solvent, throughout France, at 4 per cent. This was demolished by Mollien in a masterly paper on the theory of discount, to which the Emperor submitted. A second project was to create an immense mont de piété, to make advances to trade on the deposit of goods-and Napoleon proposed to devote 30 millions to this purpose. He again gave way, however, on Mollien's representing that, in the event of these loans not being repaid, it would be necessary for the State to sell the goods, which must not only ruin the borrowers, but depress the whole market. He resolved at last to make an advance of I,500,000 frs. to a mercantile house at Amsterdam, and another at Paris, on good security. In the following year (I8II) this precedent became known. A second request for a similar sum arrived, then another, and at length they poured in by hundreds from all parts of France. Still Mollien, who disapproved the whole proceeding, was condemned to find funds for this insatiable demand. The Government were threatened with disturbances in the faubourgs 
and the manufacturing towns if they did not yield; and they yielded. A million was sent down to Amiens, to be advanced by instalments of $20,000 \mathrm{frs}$. a day; two millions were spent at Rouen, St. Quentin, and Ghent. These operations were conducted with secrecy, and in some instances they enabled the manufacturers to escape impending ruin : but upwards of eighteen millions had been spent by the Treasury in lending money to men who could borrow nowhere else, and whose commercial existence was barely prolonged by the assistance they received.

It is difficult to conceive how Napoleon, with his lofty and incontestable penetration, failed to perceive the singular contradiction into which he fell by persisting in his Continental blockade at the very time he was acknowledging by these advances to trade that the system caused his ruin-placing himself in the dilemma of either exhausting the Treasury and the privy purse (if he attempted to indemnify trade for its losses), or (if he confined his liberality to a small class of traders) of augmenting the complaints of those whom he had not relieved. Yet it must be confessed the fault was not his alone. Never, since the commencement of the long commercial hostility of France and England, which broke out with fresh fury after the truce of ${ }_{17} 87$ [Mr. Pitt's treaty], had the frenzy of prohibitive laws been more universal or more popular than in $\mathbf{1 8 0 0}$, when Napoleon took the helm. There seemed to be a common interest between the traders - who never thought the"custom laws severe enough against England-and the Treasury, which still hoped to increase its receipts by excessive duties. The advisers of Napoleon on commercial matters were all traders and ultra-prohibitionists. After the rupture of the Treaty of Amiens-which was not a treaty of peace and still less a 
treaty of commerce-these hostile measures went on in an increasing degree between the two nations. It must be confessed that our restrictions on the liberty of the Continent, because England refused liberty to our ports, were an injustice the more irritating because it could not be realised; but with the exception of a few persons whom he never consulted on the subject, those about the Emperor constantly endeavoured to keep up his illusions. He was always reading reports that all nations were sighing for the liberty of the seas, and that he was to break the yoke of British monopoly. When the English paid for their supplies from abroad in money, he was persuaded that British capital was migrating from that inhospitable soil to France. He was persuaded that cotton could grow in Naples, and tobacco in Alsatia. $\mathrm{He}$ lived, in short, under constant delusions of this nature. Yet, if we consider how long the Continental system lasted, and the perturbation it caused in all the usages and results of trade, it was certainly the most extraordinary coup d'état ever attempted; and I know not which is most surprising - the daring of its authors, or the submission of all the interests aggrieved by it.

Although Count Mollien (for he had now received this title), in spite of a clear perception of Napoleon's errors, yielded to no one in fidelity to his service, any more than in admiration of his genius, he does not appear to have been at any time dazzled by his fortune or overpowered by his authority. Napoleon himself paid him the highest compliment that absolute power can pay to the sagacity of a minister by silently acquiescing in his views and adopting them towards third parties as his own. Mollien's influence was strictly limited to the business of his 
own department, and he took no part in the general policy of the Government, for whose pecuniary wants he was continually called upon to provide; but, nevertheless, he was not unfrequently selected as the depositary of opinions entertained by the most moderate party in the Imperial councils. Thus in I 809, when Paris was literally thronged with tributary kings, and the sovereign houses of Germany seemed allied to the upstart sovereigns of Naples, Spain, and Westphalia, Eugène Beauharnais had the sense and penetration to say to Mollien :-

'The Emperor is mistaken on the state of Europe. Perhaps these sovereigns, who owe an extension of territory to his support, are themselves mistaken in the disposition of their subjects. But the nations of Europe are not mistaken as to this new dominion exercised over them by one people, or rather by one man. They will never be our allies in good faith, these nations whose defeat is our glory, and whose misfortunes are our success. They were already humiliated by defeat and by tribute: they are more humiliated now by seeing their own sovereigns summoned to the capital of the conqueror to adorn his triumph. But the humiliation of nations bears sooner or later a harvest of vengeance. I fear nothing, indeed, as yet for France; but if I like war it is for the sake of peace, and I see no lasting peace for the world.'

Such was the language of the wisest and most faithful adherent of Napoleon in his own family, at a time when there was but one sentiment in France and in her new dependencies-universal submission. And it is the more honourable to Prince Eugène that he had the courage to hold pretty nearly the same language to Napoleon himself. 
The state of voluntary self-delusion, which was necessary to the maintenance of Napoleon's system, increased, year after year, with the increase of his difficulties. In spite of what he considered his searching analysis of the finances, he laboured not so much to arrive at the truth as to convert a deficiency into a surplus by complex calculations and unfathomable arithmetic. His mind, unshaken by the ruinous outlay of the Spanish war, was already fixed in I8I I on the Russian campaign, which was to extend his domination from Madrid to Moscow; and he continued to thrust additional military estimates, to the amount of 60 millions, on the budget of the preceding year, evidently anticipating that the balance would be adjusted by the Russian tribute at the close of the war. In the secret discussion of his financial resources which took place between Napoleon, the Duc de Gaëte, and Mollien, the latter represented the increasing embarrassments of the Treasury, as no loans could be contracted, and at the first rumour of another war public credit would be still further depressed. To this Napoleon replied with vivacity-

'If I am compelled to undertake another war, it will certainly be for some great political interest; but it will also be in the interest of my finances. Have I not always restored them by war? Was it not thus that Rome conquered the riches of the world?" 
I quote the Duc de Gaëte as witness of this extraordinary declaration with myself. I quote the incident as a proof of the strange blunders into which the intoxication of power may lead the most powerful minds. From that moment I held the power of Napoleon to be seriously in jeopardy.

It was about this time that an occurrence took place which reveals a singular portion of the secret history of that ephemeral Court. Napoleon, who esteemed few people, never gave unlimited confidence to a human being: but if any one at all touched the springs of his affection it was Josephine. Nor did this interest cease after her divorce, though it was somewhat tried, and not very mildly ex.pressed, when her extravagant habits continued to annoy him. Josephine had an allowance of three millions of francs ( $120,000 l$.) when she retired to Malmaison, but before a year had elapsed she was again in debt. Napoleon then addressed to Mollien the following letter :-

Wesel, rst November, r81 r.-It is proper that you should send secretly for the Empress Josephine's intendant, and tell him confidentially that nothing will be paid in future until he give proof that there are no debts: and as I will have no jesting on this matter, I shall hold him responsible. You will tell him that no payment will be made on the Ist January without a written certificate that there are no debts. I am informed that the expenses of this house are most irregular; you must therefore see this man, for it would be deplorable that the Empress Josephine should have debts instead of laying by two millions a year as she ought 
to do. Take an opportunity of seeing the Empress Josephine yourself, and hint to her that I expect her house to be managed with order, and that I shall be supremely displeased if it be not. The Empress Louise has 100,000 écus ( $12,000 l$.), and never spends that sum; she pays her bills once a week, goes without new gowns if that be necessary, and suffers privations to avoid having debts. The expenses of the Empress Josephine's household ought not to exceed one million. If there are too many horses, cut them down. The Empress Josephine has children and grandchildren for whom she ought to lay by. Sur ce, \&c.

Mollien executed this task, and on receiving his report, Napoleon insisted still further on the savings to be made for her family, adding, that they ought not to depend on him alone, and then-for once in a somewhat broken voice- ' Fe suis mortel, et plus qu'un autre.' The Empress had cried on hearing these remonstrances, and complained that she could no longer pay pensions to some old soldiers, probably of the Royalist party. Napoleon said, "You should not have made her cry, though. Give me the names of those officers; and tell her not to cry.' Yet how many tears this selfish and ungrateful man had cost that repudiated woman and the world!

The time at length arrived when the clouds which had been gathering on the horizon of Europe broke with all their fury on the presumptuous and infatuated ruler of France. The campaign of Moscow sent him home impoverished by defeat, not enriched 
by conquest; his army destroyed-the prestige of his name woefully tarnished. On his sudden return to Paris Mollien was one of the first persons he sent for. Not without anxiety and alarm did he enter the presence. But Napoleon received him with perfect serenity and self-possession_-inquired eagerly for Madame Mollien, who had been dangerously ill - said he had travelled as uncomfortably as when he was a lieutenant of artillery, but that it did not signify-adverted to the Mallet conspiracy in Paris -and made no allusion either to the tremendous calamities of the still unfinished campaign or to the financial difficulties of Mollien's own department. The public were not entirely duped by this show of composure, for the bulletin of the Beresina had told the story of ruin, and every fresh arrival from the army increased the sense of horror and insecurity. But they hoped that so severe a lesson would not be lost on the Emperor, and that if he were again placed at the head of an army it would at last be to contend for peace.

Nothing in Bonaparte's career was more extraordinary than the energy he displayed during the winter of I 8 I 2-I 3. The cavalry had to be remounted, the artillery to be entirely re-organised, a great part of the infantry to be clothed, immense quantities of 
arms to be provided, munitions of war to be collected in all the fortresses; and the whole was to be done in six months. Strange to say the conscriptions were never more readily filled up than after the disastrous campaign of I8I2. The country still supported him, and since he had fallen upon evil days, it was content to share them with him. The accusing voices of 1814 were not yet audibly heard; the defence of the territory was the prevailing sentiment, and Napoleon encouraged the self-devotion of the people by the hope of approaching peace. Immense levies were ordered. The financial measures resorted to in order to defray new and immoderate charges were startling. Thus Maret proposed and his master sanctioned the appropriation by the State of all the common lands belonging to parishes throughout France, which were to be sold, and the communes to receive their value in the shape of funded capital. This project was expected to bring in 300 millions-which being forthwith spent by anticipation, the Government was once more living on credit alone. It was an imitation by Napoleon of the revolutionary acts by which the Convention had begun the war. Mollien, in forcible terms, pointed out the defects of such a scheme, but the condition of the finances was already such 
that only the choice of bad means was left him. Yet no sooner did Napoleon find himself at the head of another army than he changed his tone, declaring that, ' to be worthy of herself, France must abstain from pusillanimous desires; that her first object must be to avenge her offended glory; and that the only peace she could make was a peace extorted by new victories and recognizing all her former conquests.' The difficulties he encountered seemed to surprise without instructing him. But his labours were enormous. The whole day was spent in warlike preparations-the night in administrative correspondence. Some of his letters to Mollien entered into the minutest calculations. One of them consisted of eight pages of figures. Even on his arrival at Mayence, to put himself at the head of the army in the field, he stopped several hours to investigate the accounts of the military chest on the frontier. Twelve days later he fought the battle of Lutzen with 85,000 men, and in three weeks after I 50,0no more had joined his standard. But his efforts and his hopes of securing the neutrality of Austria failed. The great coalition was formed in September, and in October the battle of Leipzig again annihilated the French army, and left Napoleon no resource but a hasty retreat on the Rhine. 
Throughout this period, and indeed from the first reverses of the Russian campaign, the regular and punctual course of the administration of the Treasury was at an end: and Mollien, who invariably recognised in exact payment the test of strength and stability for a Government, had already long before the disasters of I8I4 made up his mind that the case of the Empire was desperate. When Marie-Louise retired to Blois he followed her, leaving the control of the Treasury to his friend and disciple Baron Louis, who was destined to render the most important services in that capacity to the future government of Louis XVIII. Mollien was sent for on the return from Elba, and, under a sense of personal obligation to his old master, did not refuse to resume the office he had filled with honour for nine years. But he has disdained to record in these Memoirs the fugitive occurrences of that feverish interval. When summoned to the Tuileries on that occasion he had formed a resolution to resist the proposal. Napoleon was alone when he entered the closet, and said, taking him by both hands, 'In this crisis you will not refuse to take your old place in the ministry.' To some complimentary remark on the miraculous success of his return, the Emperor replied, 'Mon cher, the time for compliments is over. 
Ils m'ont laissé arriver comme ils les ont laissés partir'-an expression which proves the more correct estimate he had at length formed of the French character-his feeling, in short, that the vicissitudes of fortune to wh:ch he had himself accustomed that people must have prepared them for viewing with indifference any possible revolution, even from the excess of freedom to the excess of servitude.

M. Mollien candidly acknowledges that as his principal object was to bequeath to the world a correct portrait of Napoleon, especially in those relations of life which fell under his own cognizance, so it is not without regret that he has recorded much to darken the fame of one who was to him an object not only of high intellectual admiration, but of grateful regard. He has steered clear of the servility of a Las Cases and of the malignity of a Bourrienne; and while others have depicted the policy and character of Napoleon from their personal motives of affection or of resentment, Mollien discusses them with reference to the fixed principles of public economy and of public morality from which his own career never deflected. But though the narrator of these transactions has not sought to exalt his own penetration and experience at the expense of his 
master, and has displayed in a remarkable manner the versatility and application with which that $\mathrm{ex}^{2}$ traordinary man governed his immense empire, he has entirely failed to raise our conception of Napoleon's real competency to deal with these abstruse subjects. In these pregnant volumes we have not met with a single idea originating with the Emperor himself on points of finance or political economy which is not radically unsound. He seems to have thought on these matters as he did on the obligations of public morality, that a code of science and of duty could be framed to suit his own convenience, and that motives of State sufficed to cover every enormity. But he was eminently skilled in the choice of instruments, and his insatiable activity kept every department of the Government in constant efficiency. The last mark of confidence he would bestow on those who really possessed it was the tacit adoption of their opinions, even when he had just before combated them. He was tolerant of contradiction when alone, but absolutely oracular when he held forth in the Council of State or in public. In reality he had no financial principies : the perpetual recurrence of war, the Continental blockade, and his own crude notions of public credit prevented the formation of such a system at any VOL. I. E E 
part of his reign; and the last extravagant and destructive years of the Empire shook and wellnigh obliterated the advantages resulting from the methodical reforms of the Consulate. Admitting therefore the extraordinary military successes and political energy which had extended that vast dominion over Europe, M. Mollien has failed to show that it possessed those sound and practicable financial views which are inseparable from the stability of Governments and the contentment of nations. His own administration of the Treasury was a long struggle against incoherent projects and reprehensible expedients; and the ground he was continually endeavouring to strengthen and consolidate was as continually cut from beneath his feet by the exorbitant demands of the military and political departments. His official duties were rather fiscal than financial, and he never had the power or the opportunity of altering the great springs of taxation that pressed, and still press, so injuriously on the French nation. No alleviation could take place in the condition of the people- no safe or permanent extension could be give to trade; and at length war, which had been the principal source of this misery and pressure, was resorted to as the easiest mode of palliating them. Austerlitz and Moscow were 
the projects of an insolvent gambler. The daring expedient was successful in the one case and ruinous in the next; for, as his whole system of credit was stimulated and kept alive by victory, it collapsed at once under defeat. We will not here detain our readers to apply to the politics of France in the present day the analogies which these facts can hardly fail to suggest ; but if similar embarrassments should drive Louis Napoleon Bonaparte to similar enterprises, that is to the vulgar resource of foreign spoliation, there is, we fear, no Mollien in the councils of the Elysée to resist and correct such lawless and self-destructive tendencies. Under the Imperial administration at least the spendthrift vices of the present Government were unknown; and indeed no one would have repressed them with more severity than Napoleon himself. ${ }^{1}$

1 I leave this observation as it was written many years ago, when the progress of the Second Empire to its ruin, and the final catastrophe of its fate, could only be dimly discerned in the future. The result of its matchless extravagance is now before the world. But it is not less distressing to remark that the same absence of sound financial principles, the same disposition to resort to false fiscal expedients, the same faith in the obsolete maxims of protection, still pervade the French Government and a considerable portion of the National Assembly. They appear to have learned nothing by the experience of several generations, and to have inherited many of the worst delusions of their predecessors. For among the causes which have heretofore defeated the establishment and maintenance of a free and constitutional government in France, none has been more powerful than the fact that not 
Little remains to be said of the later years of Count Mollien's life, for his official career terminated with the final fall of his Emperor, and he closes his own narrative at that period. But, though he held no office of public trust under the Bourbons, he was placed by Louis XVIII. in the Chamber of Peers, where he continued, until the latter part of the reign of Louis Philippe, to treat with great superiority and with perfect consistency the financial questions of the day. In private life he was respected for the sobriety of his judgments and the steadiness of his friendships ; nor would his character have been complete without the charm which his unvarying conjugal affection shed over it. Well were it for France if, amongst her men of wit and her men of action, there were more possessed of the reflection and composure which these volumes attest; or if, when such men are to be found, they were raised to a higher position in the State, so as to control the impulses of their. countrymen. Sooner or later all Governments are judged by their adherence to, or departure from, sound fixed principles; and the Empire of Napoleon

one of these governments - whether free or despotic-ever took its stand on perfectly sound financial and economical principles. Whenever a radical vice or error exists in the first principles of government, it will assuredly work its way to the surface, sooner or later, in the shape of a revolution. [1872.] 
himself was, as this narrative proves, tainted with the mortal disorder of financial embarrassment in the midst of its most brilliant achievements. The welfare and stability of nations require more homely virtues, and more provident care; of which qualities these volumes will perpetuate an honourable example and an unpretending picture.

END OF THE FIRST VOLUME. 





\section{please do not Remove}

\section{CARDS OR SLIPS FROM THIS POCKET}

\section{UNIVERSITY OF TORONTO LIBRARY}


